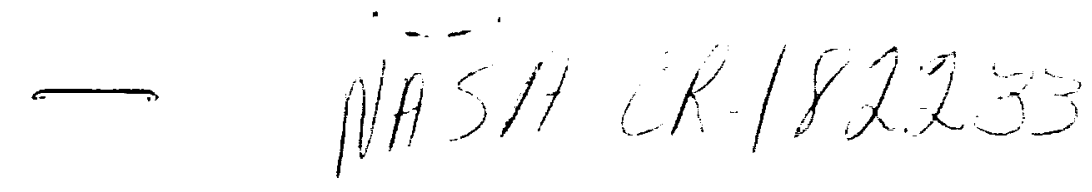

\title{
ADIABATIC WANKEL TYPE ROTARY ENGINE
}

\section{PHASE II FINAL REPORT}

BY

R. KAMO, P. BADGLEY, AND D. DOUP

ADIABATICS, INC.

COLUMBUS, INDIANA

PREPARED FOR

\section{NASA LEWIS RESEARCH CENTER}

\section{CONTRACT NAS3-24880}

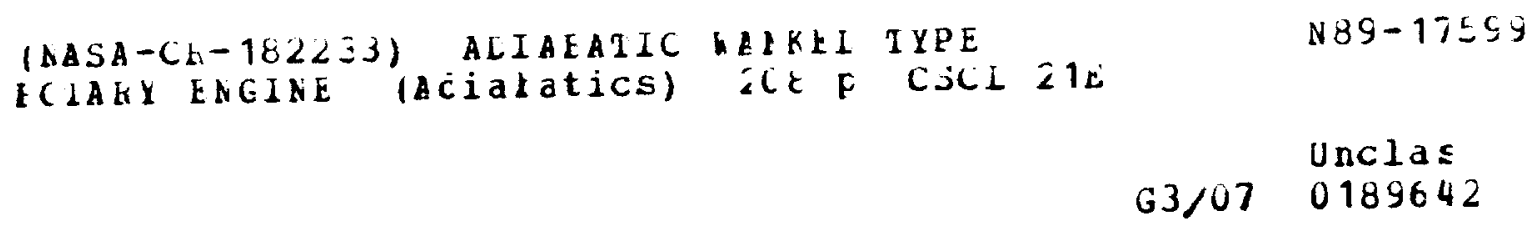

SEPTEMBER 1988 
$\ldots$ 


\begin{tabular}{|c|c|c|}
\hline $\begin{array}{l}\text { REPORT DOCUMENTATION } \\
\text { PAGE }\end{array}$ & 1. REPUETT NO. & 3. Reclplent's Accession No. \\
\hline \multirow{2}{*}{\multicolumn{2}{|c|}{$\begin{array}{l}\text { 4. Thle and Subillo } \\
\text { Adiabatic Wankel Type Rotary Engine }\end{array}$}} & $\begin{array}{l}\text { 5. Repon Dole } \\
\text { Sept. } 1988 \\
\end{array}$ \\
\hline & & 6. \\
\hline \multicolumn{2}{|l|}{$\begin{array}{l}\text { 7. Author(s) } \\
\text { R. Kamo, }\end{array}$} & $\begin{array}{l}\text { 8. Performine Orgenization Rept. No. } \\
\text { AI }-120\end{array}$ \\
\hline \multirow{2}{*}{\multicolumn{2}{|c|}{$\begin{array}{l}\text { Adiabatics, Inc. } \\
630 \text { South Mapleton Street } \\
\text { Columbus, Indiana } 47201\end{array}$}} & 10. Prolect/Tash/Work Unit Ho. \\
\hline & & $\begin{array}{l}\text { 11. Contract(C) or Grant(G) No. } \\
\text { (c) NAS } 3-24880 \\
\text { (G) }\end{array}$ \\
\hline \multicolumn{2}{|c|}{$\begin{array}{l}\text { National Aeronautics and Space Administration } \\
\text { Lewis Research Center }\end{array}$} & 13. Type of Report \& Perlod Covered \\
\hline \multicolumn{2}{|c|}{$\begin{array}{l}\text { Attn: Mr. John McFadden, Mail Stop 77-6 } \\
\text { Cleveland, Ohio } 44135\end{array}$} & 14. \\
\hline
\end{tabular}

\section{Supplementary Notos}

Project Manager, J. McFadden, NASA-Lewis Research Center, Cleveland, Ohio 44135

16. Abstract (LImlt: 200 words)

This SBIR Phase program accomplished the objective of advancing the technology of the wankel type rotary engine for aircraft applications through the use of adiabatic engine technology. Based upon the results of this program, technology is in place to provide a rotor and side and intermediate housings with thermal barrier coatings.

A detailed cycle analysis of the NASA 1007R Direct Injection Stratified Charge (DISC) rotary engine was performed which concluded that applying thermal barrier coatings to the rotor should be successful and that it was unlikely that the rotor housing could be successfully run with thermal barrier coatings as the thermal stresses were excessive.

\section{Documene Analyzis a. Descriplors}

Wankel rotary engine, Adiabatic engine, Wankel Simulation Model, Aircraft engines, Turbocharging, Turbocompound.

b. Identiflers /Open-Ended Terms

c. COSATI Flold/Group

18. Availobility Stotemen:

Unclassified

19. Security Clese (Thla Roport) Unclassified

20. Securlty Class (This Pace) Unclassified
21. No. of Paces 215

22. Price 
1 


\section{ADIABATICS WANKEL TYPE ROTAY ENGINE \\ PHASE II}

TABLE OF CONTENTS

1.0 Introduction . . . . . . . . . . . . . . . . . . . . . . 1

2.0 Executive Summary. . . . . . . . . . . . . . . . . . . . . 1

3.0 Background-Phase I. . . . . . . . . . . . . . . 2

4.0 Technical Approach . . . . . . . . . . . . . . . . . . 2

5.0 Discussion . . . . . . . . . . . . . . . . . . . 3

5.1.0 Task I Engine Selection and Baseline Testing 3

5.1.1 Engine Selection. . . . . . . . . . . 3

5.1.2 Engine Test Plan. . . . . . . . . . . . . 5

5.1.3 Baseline Testing. . . . . . . . . . . . . 5

5.2 Task II Thermal Analysis. . . . . . . . . . . . . . . 6

5.3 Task III Adiabatic Component Design. . . . . . . . . 8

5.4 Task IV High Temperature Apex/Side Seal Tribology . . 8

5.5 Task V Prototype Engine-Procurement/Assembly-Mazda 13B 14

5.5.0 Rotor................. . 14

5.5.1 Side Housing. . . . . . . . . . . . . 16

5.5.2 Rotor Housings. . . . . . . . . . . . 20

5.6 Task VI Engine Testing. . . . . . . . . . . . . . . . 28

5.6.0 Intermediate Housing. . . . . . . . . . . . 28

5.6.1 Rotor... . . . . . . . . . . . . . . 29

5.6.2 Rotor Housing . . . . . . . . . . . . . . 37

5.7 Task VII Prototype Engine - Procurement/Assembly
- NASA 1007R. . . . . . . . . . . . . . . 54

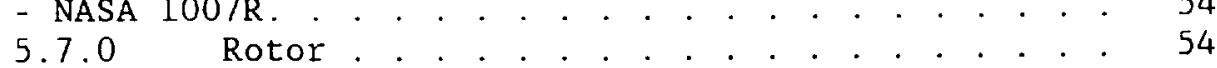

5.7.1 Side Housings . . . . . . . . . . . . . . . 60

5.7.2 Rotor Housing . . . . . . . . . . . . . 64

5.8 Task VIII Exhaust Energy Utilization. . . . . . . . . 64

5.9 Task IX Reporting . . . . . . . . . . . . . . . . 76

6.0 Conclusions. . . . . . . . . . . . . . . . . . . . . 76

7.0 Recommendations. . . . . . . . . . . . . . . . 82

Appendix A . . . . . . . . . . . . . . . . . . . A-1

Appendix B . . . . . . . . . . . . . . . . . . . . . . . . B-1

Appendix C . . . . . . . . . . . . . . . . . . . . . . . . $\mathrm{C}-1$

Appendix D . . . . . . . . . . . . . . . . . . . . . . . . $\mathrm{D}-1$ 


\section{ADIABATICS WANKEL TYPE ROTAY ENGINE}

PHASE II

TABLE OF CONTENTS

Section

Appendix E . . . . . . . . . . . . . . . . . . . . . . . . E-1

Appendix F. . . . . . . . . . . . . . . . . . . . . . . . $F-1$

Appendix G-I . . . . . . . . . . . . . . . . . . . . . . . G-I-1

Appendix G-II. . . . . . . . . . . . . . . . . . . . . . G-II-1

Appendix $\mathrm{H}$. . . . . . . . . . . . . . . . . . . $\mathrm{H}-1$

Appendix I... . . . . . . . . . . . . . . . . . I-1 


\title{
ADIABATIC WANKEL TYPE ROTARY ENGINE \\ PHASE II
}

\author{
LIST OF ILLUSTRATIONS
}

$5 \cdot 1 \cdot 3-1$

$5.4-1$

$5.4-2$

$5.4-3$

$5.5 .0-1$

$5.5 .0-2$

$5.5 .0-3$

$5.5 .0-4$

$5.5 .1-1$

$5.5 .2-1$

$5.5 .2-2$

$5.5 .2-3$

$5.5 .2-4$

$5 \cdot 6 \cdot 0-1$

$5.6 .0-2$

5.6.0-3

5.6.0-4

5.6.0-5

5.6.1-1

$5.6 .1-2$

5.6.1-3

5.6.1-4

5.6.1-5

5.6.1-6

5.6.1-7

5.6.1-8

5.6.1-9

5.6.1-10

5.6.1-11

5.6.1-12

5.6..1-13

Mazda Engine Ready for Baseline Testing . . . . . . . 7

Scematic Drawing of Friction and Wear Test Rig. . . . 11

Thermocouple Installation for Roller and Specimen

Temperature Measurement . . . . . . . . . . . . . . 12

Drawing of Friction and Wear Test Rig Assembly. . . . 13

Details of Zirconia Coating Applied to Mazda

13B Rotors. . . . . . . . . . . . . . . . . . . . 15

Zirconia CoatedRotor After One Densification Cycle. . 17

Machined Mazda Rotor with Lip Design Around the

Combustion Chamber. . . . . . . . . . . . . . . . . . 18

Mazda Rotor After Adiabatics, Inc. Low Temperature

Densification . . . . . . . . . . . . . . . . . . . 19

Details of Zirconia Coating on Mazda 13B Intermiediate

Housing . . . . . . . . . . . . . . . . . . . . . . . 21

Stock Aluminum Mazda Rotor Housing After Zirconia (a)

and Tribaloy 800 (b) Application. . . . . . . . . . . 23

Failed Tribaloy 800 Coating on Mazda Stock Aluminum

Rotor Housing. . . . . . . . . . . . . . . . . . . . 24

Cast Iron Rotor Housing After Initial Machining . . . 25

Coated Cast Iron Rotor Housing Showing "Mud" Cracks

After Zirconia Densification. . . . . . . . . . . . 27

Zirconia Coated Intermediate Housign Densified by

Kaman Science's Process After Completing 51 Hours

of Testing. . . . . . . . . . . . . . . . . . 30

Change in Oil Temperature vs. Bmep Chart. . . . . . . 31

Change in Oil Temperature vs. Bmep Chart. . . . . . . 32

Change in Oil Temperature vs. Bmep Chart. . . . . . . 33

Change in Oil Temperature vs. Bmep Chart. . . . . . . 34

Rear Rotor Housing After 31 Hours of Testing Time

with Thermal-Barrier-Coated Rotor . . . . . . . . 35

Undensified Zirconia Coated Mazda Rotor After 100

Hours of Testing. . . . . . . . . . . . . . . . 36

Change in Oil Temperature vs. Bmep Chart. . . . . . . 38

Change in Oil Temperature vs. Bmep Chart. . . . . . . 39

Change in Oil Temperature vs. Bmep Chart. . . . . . . 40

Change in Oil Temperature vs. Bmep Chart. . . . . . . 41

Change in Oil Temperature vs. Bmep Chart. . . . . . . 42

Change in Oil Temperature vs. Bmep Chart. . . . . . . 43

Change in Oil Temperature vs. Bmep Chart. . . . . . . 44

Change in Oil Temperature vs. Bmep Chart. . . . . . . 45

Change in Oil Temperature vs. Bmep Chart. . . . . . . 46

Change in Oil Temperature vs. Bmep Chart. . . . . . . 47

Densified Zirconia Coated Mazda Rotor After 100

Hours of Testing. . . . . . . . . . . . . . . . 48 


\section{ADIABATIC WANKEL TYPE ROTARY ENGINE}

PHASE II

\section{LIST OF ILLUSTRATIONS (Cont.)}

Figure

Title

Page

5.6.1-14 Stock Mazda Rotor (a) Compared with Densified Coated

Rotor After 100 Hours Testing Together in One Build. 49

5.6.2-1 Failed Thermal Barrier Coating on Mazda Rotor Housing

After 14 Hours of Testing . . . . . . . . . . . . . . 51

5.6.2-2 Coated Cast Iron Rotor Housign After Testing 16.75 Hours... . . . . . . . . . . . . . . . . 52

5.6.2-3 Warped M2 Tool Steel Apex Seals Tested with Coated Cast Iron Rotor Housing . . . . . . . . . . . . . . . 53

$5.6 \cdot 2-4$

Warped Standard Cast Iron Apex Seals Tested with

Coated Iron Rotor Housing . . . . . . . . . . . . . . 55

$5.6 .2-5$

Coated Cast Iron Rotor Housing After 32.3 Hous of Testing.................... . . 56

$5.6 .2-6$ Adiabatics' Slurry Coating on a Mazda Side Seal (below) Compared to a Stock Side Seal (top) After 32.5 Hours of Testing. . . . . . . . . . . . . . . . . 57

5.7.0-1 1007R Rotor After machining Process Showing the Lip of Untouched Material Around the Combustion Chamber. . . 59

5.7.0-2 1007R Rotor Shown (a) After Zirconia Application and (b) After Zirconia Densification. . . . . . . . . . 61

5.7.0-3 Details of the Thermal Barrier Coating on the 1007R Rotor. . . . . . . . . . . . . . . . . 62

5.7.1-1 Details of Thermal Barrier Coating on the 1007R Aluminum Side Housing . . . . . . . . . . . . . . 63

5.7.1-2 1007R Side Housign After Machining (a) and Final Lapping (b)... . . . . . . . . . . . . . 65

$5.7 .1-3$ Cracking Around the Crankshaft Hole of 1007R Side Housing After Final Lapping . . . . . . . . . . . . . 66

5.7.2-1 Details of Thermal Barrier Coating on the 1007R Aluminum Rotor Housing. . . . . . . . . . . . . . . 67

5.7.2-2 1007R Rotor Housign Shown After Zirconia (a) and Tribaloy 800 (b) Application. . . . . . . . . . . . 68

5.8.1 Power Available in the Exhaust Chart. . . . . . . . . 70 
ADIABATIC WANKEL TYPE ROTARY ENGINE

PHASE II

\section{LIST OF TALBES}

Table

Title

$\underline{\text { Page }}$

Table 1 Configuration of the Mazda 13B Engine... . . . . . 5

Table 2 Prototype Procurement - Mazda 13B... . . . . . . . . 9

Table 3 Testing Results - procured Mazda 13B Components . . 58

Table 4 prototype Procurement - NASA 1007R. . . . . . . . . . 70

Table 5 1007R Baseline Engine Basic Engine Configuration. . $\cdot 71$

Table 6 Engine Operating Condisitons and Performance. . . . . 73

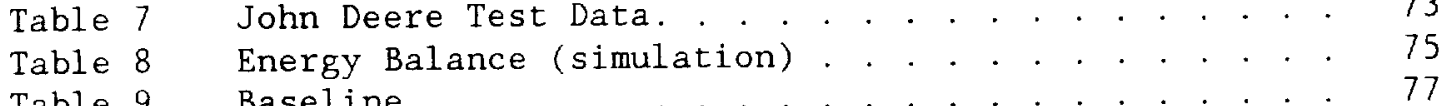

Table 9 Basle 10 Insulated, Cooled Engine. . . . . . . . . . . . . . . . . . . . 78

Table 11 Insulated, Uncooled Engine Input. . . . . . . . . . . 79 
1 


\subsection{Introduction}

This final report is prepared by Adiabatics, Inc. for the National Aeronautics and Space Administrations' Lewis Research Center (NASA LeRC) per an SBIR contract No. NAS3-24880 as amended in Modification No. 2. This report documents the two-year SBIR Phase II program, from July 10, 1986 to September 10, 1988, to develop and test a prototype low-heat-rejection rotary engine.

This SBIR Phase II program was a result of the studies performed in the Phase I contract entitled "Adiabatic Wankel-Type Rotary Engine" completed in 1985. Under Phase I, an analytical study, significant results in areas such as decreased fuel consumption and increased power output were cited when thermal-barrier (insulative) coatings were applied to internal components of the rotary engine, and with the subsequent removal of the cooling system.

The work in this Phase II program was the first step in applying the ideas and theory elaborated in Phase I to an actual engine. The objective of this Phase II project was to design, fabricate, procure, assemble, and test a prototype low-heat-rejection rotary engine to see if the results of Phase $I$ are actual and that this type of engine can run dependably.

\subsection{EXECUTIYE SUMAARY}

This SBIR Phase II program accomplished the objective of advancing the technology of the Wankel type rotary engine for aircraft applications through the use of adiabatic engine technology. Curtiss-Wright and John Deere as part of their "Technology Enablement" program for aircraft rotary engines have identified a need for reduced heat rejection as a key technology for a highly advanced aircraft engine [1].

Based upon the results of this program technology is in place to provide a rotor (using either the available $17-4 \mathrm{PH}$ stainless steel rotor or preferably a titanium alloy rotor) and side and intermediate housings (of preferably titanium alloy) with proven thermal barrier coatings. These components by themselves make a large improvement in the engine package by substantially reducing the net heat transfer and thus reducing the size and weight of the cooling systems (lube and coolant) and will also improve the efficiency of the engine by improving the combustion through increased cycle temperatures. To achieve the best overall powerplant package a single high temperature fluid combining lubrication and rotor housing cooling should be incorporated. Incorporation of a compounding cycle such as turbo-compounding or a bottoming cycle will be even more attractive and show larger benefits as more heat is diverted from coolant to the exhaust.

A detailed cycle analysis of the NASA 1007R Direct Injection Stratified Charge (DISC) rotary engine was performed by ADAPCO, Inc. utilizing the DISC cycle simulator developed by MIT under a program sponsored by NASA. The analysis was calibrated by matching measured performance data supplied by John Deere. The analysis was then conducted for two cases consisting of both an uncooled engine with thermal barrier coatings on cast iron engine housings and an intermediate case with thermal barrier coatings on water cooled aluminum housings with thermal barrier coatings on the rotor in both cases. A finite element model for the 1007R rotor and rotor housing was developed for each of the three cases (standard water cooled, thermal barrier coatings with water cooling, and thermal barrier coating with no cooling). Detailed thermal and 
stress analyses were then performed for these three cases utilizing boundary conditions as defined by the respective cycle simulations. This study concluded that applying thermal barrier coatings to the rotor should be successful and that it was unlikely that the rotor housing could be successfully run with thermal barrier coatings as the thermal stresses were excessive.

Concurrently with the analytical study all of the major internal engine components including the rotors, rotor housings and side housings have been coated with thermal barrier coatings and the components durability tested in a racing Mazda engine for over 300 test hours. The Mazda engine was utilized for this design and durability screening effort rather than the 1007R engine for reasons of availability and cost effectiveness and because it runs hotter that the DISC engine which serves to accelerate the testing.

The results of the iterative design, fabrication and testing cycles are that successful designs for both the rotor and side housings with thermal barrier coatings are proven and that the use of thermal barrier coatings on the rotor housing appears to raise the inner surface temperature to the point where available liquid lubricants are inadequate to lubricate the apex seal interface.

Based upon the test results, components have been supplied to NASA for the NASA 1007R engine which have been modified with thermal barrier coatings. The plan is for NASA to have the components engine tested by John Deere's Rotary Engine Division to determine their performance in the DISC engine.

\subsection{Backeround-Phase I}

The SBIR phase I program was an analytical study of the potential benefits of the adiabatic Wankel-type engine and advanced heat engine concepts. Also, the design of adiabatic engine components, methods of applying ceramic (insulative) materials, and the technical feasibility of an adiabatic Wankel engine concepts were presented. The baseline engine selected for this study was the single rotor 1007R engine built by John Deere and owned by NASA. The 1007R is a highly advanced, stratified charge, 0.71 iter prototype engine.

The results of the Phase I study confirmed a significant improvement in the performance of the Wankel engine when modified to be adiabatic. Also, advanced concepts like turbocompounding, advanced turbocharging, high compression ratios, faster combustion, and reduced leakage showed significant improvements in engine performance. An overall improvement of $25.5 \%$ in ISFC and $34.5 \%$ in power output was predicted for the 1007R engine when $100 \%$ adiabatic and turbocharged. The potential application and performance benefits of the low-heat-rejection Wankel engine are extremely attractive for future advanced power plants for aircraft, automotive, and industrial engines. These discoveries and potential benefits are what prompted the funding of Phase II.

\subsection{Technical Approach}

To meet the objectives of this Phase II project a management plan was developed whereby Phase II was broken into two separate parts. The first part to be performed by Adiabatics Inc. consists of development of insulated components. A Management Plan submitted by Adiabatics Inc. at the beginning of the program is found in Appendix A. The second part consists of testing the fully insulated engine which will be performed by John Deere at a later date. 
To meet the first contract objectives, a nine-task plan was developed is as follows :

\section{Tasks}

1. Engine Selection and Baseline Testing,

2. Thermal Analysis,

3. Adiabatic Component Design,

4. High Temperature Apex/Side Seal Tribology,

5. Prototype Engine-Procurement/Assembly-Mazda 13,B

6. Engine Testing,

7. Prototype Engine-Procurement/Assembly-NASA 1007R,

8. Exhaust Energy Utilization. and

9. Reporting.

\section{$5.0 \quad$ Discussion}

The following sections detail each of the tasks from start to finish.

\subsubsection{Task 1 Engine Selection and Baseline Testing}

An economic and feasibility study was to be made to select the best rotary engine available for modification to an adiabatic design. After selection of the engine. an engine test plan was to be conceived and baseline testing commenced. The candidate engine needed to be both easy and economical to modify while offering as much control of the hot combustion as possible and capable of producing enough power output to meet NASA's requirements for use in light aviation.

\subsubsection{Engine selection}

Engine selection was based on the following criteria:

- Ease of modification and compatibility with insulated coating,

- Lowest cost,

- Availability of spare parts,

- Fuel introduction (fuel injection into the combustion chamber being preferred), and

- Power output.

A survey of the available prototype and commercial Wankel rotary engines showed the following existing engines:

Engine

NASA 1007R Research Rig

\section{Comment}

- Only one available with John Deere

- Expensive

- Fue1 injection system meets requirements 


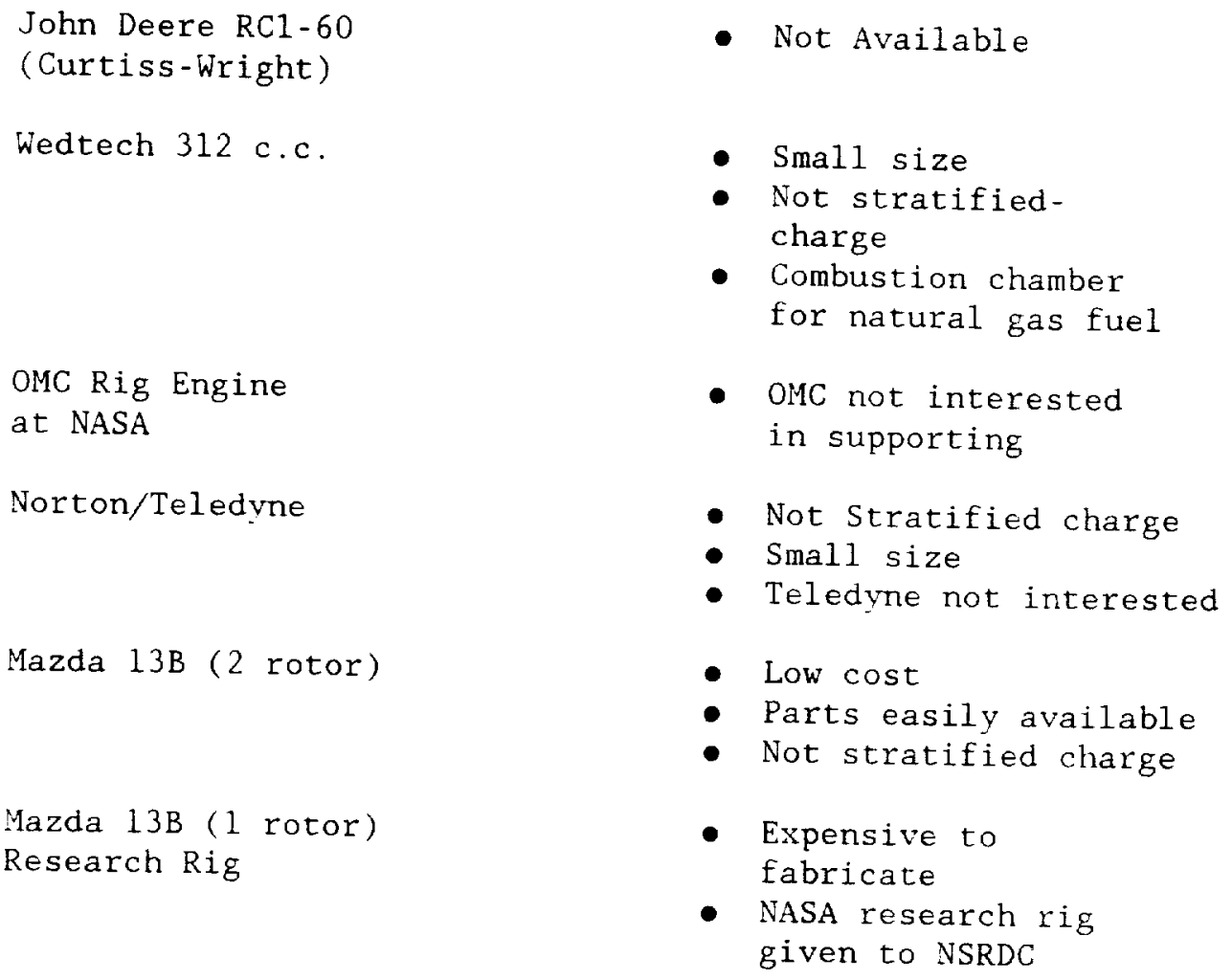

Of the above engines, only the John Deere 1007R offered the desired power output and fuel introduction system. The other engines are either not available, too small, or not fuel injected. The problem with the 1007R is it is a prototype engine and only one existed which was being used by John Deere.

The other engine which held some promise, was the naturally aspirated two-rotor Mazda 13B. Though this engine is not fuel injected, parts are readily available at low cost. Also, the Mazda has a power range comparable to the 1007R meaning both engines meet the requirements set by NASA.

The conclusion of this survey was to use the two-rotor Mazda 13B engine for component screening (mechanical screening as opposed to performance development) because of its low cost, availability of parts, and the maturity of the engine. Once components were successfully tested for durability and integrity in the Mazda, the knowledge gained would be used to modify parts for a second engine - the NASA 1007R. Assembly and testing of the uncooled adiabatic NASA engine will be under a contract performed at John Deere (the $1007 \mathrm{R}$ will then be the advanced engine which strives for the goals outlined in this SBIR Phase I report).

This selected approach was reviewed with Mr. William Hady at NASA LeRC on November 12. 1986 which was followed by a Management Plan which detailed the program.

A two-rotor Mazda 13B engine was purchased from Racing Beat Inc. of Anaheim. California. The configuration of the engine is 1 isted in the following table: 
Table 1. Configuration of the Mazda 13B Engine

$\begin{array}{ll}\text { Model } & \text { Mazda 13B } \\ \text { Displacement } & 1.308 \mathrm{~L} \text { ( } 80 \mathrm{Cu} \text { In) } \\ \text { Rated Power } & 132 \mathrm{KW} \text { (177 Horsepower) } \\ \text { Intake Ports } & 6 \text { Side Ports (2 Valved) } \\ \text { Exhaust Ports } & 2 \text { Peripheral } \\ \text { Exhaust Manifold } & \text { Racing Type Header } \\ \text { Corporation } & \begin{array}{l}\text { Dellorto } 48 \text { DHLA (Dual } \\ \text { side draft) }\end{array} \\ \text { Ignition } & \begin{array}{l}\text { Mazda Breakerless } \\ \text { distributor (Integral } \\ \text { Electronics) }\end{array} \\ \text { Ignition Coils } & \begin{array}{l}\text { Mazda Transistor Ignition } \\ \text { Type }\end{array} \\ \text { Flywheel } & \text { Lightweight Steel Type }\end{array}$

\subsubsection{Engine Test Plan}

With the test engine selected, the next step was to develop an engine test plan (Appendix B) consisting of the following:

- Descriptions of configurations being tested,

- Test conditions,

- Parameters to be measured,

- Instrumentations, and

- Detailed location of the thermocouples in the rotor housing and intermediate housing.

\subsubsection{Baseline Testing}

The first test was to baseline the engine and refine the test facility. The data gathered from the baseline test (Appendix C) were used for comparison purposes in later tests to help evaluate changes brought about by testing different insulated components. The baseline test ran approximately 23 hours.

The baseline test consisted of six (6) basic operations. The first three operations were disassembly, inspection, and reassembly. The Mazda engine was disassembled as specified in the 1987 Mazda shop manual. While disassembled, the components were inspected as specified in the Mazda shop manual.

Before reassembly, the standard rotor housings and intermediate housing were replaced with new housings which had been machined for thermocouple installation. These were the only internal components changed for instrumentation and should not effect engine performance. Engine assembly was done as specified in the Mazda shop manual. 
The fourth step was to install the engine in test cell No. 2 and connect it to the Eaton eddy-current-type dynamometer. All instrumentation was installed in a standard manner and calibrated. Pictures of the Mazda engine mounted in the test cell can be seen in figure 5.1.3-1.

The fifth operation was the test itself. Engine testing started with a compression test. The compression tester takes six (6) measurements (one for each rotor face). Next, the engine was started and run through the break-in cycle which consisted of running at varying speeds with light to no-1oad. During this run all systems were checked to make sure they were functioning properly.

A test was to be run to develop the torque curve. From the torque curve 5 test speeds were to be selected. Each of the five speeds were then to be run at $25 \%, 50 \%, 65 \%, 75 \%$, and $100 \%$ of full load. All the parameters 1 isted in the engine test plan (found Appendix B) were to then be recorded at the various speeds and loads.

The last operation was to be disassembly and re-inspection once the engine completed testing.

Although test conditions were ideal problems were encountered. The engine developed excessive vibration at high speeds and problems were encountered controlling the dynamometer. This reduced testing speeds and loads. Upon post-disassembly a source of this problem was found. A needle type thrust bearing on the crankshaft had become pinched which inhibited its "free" rotation. Another source of the problem was found part way through the second test (the coated intermediate housing test). A factory mislabeled distributor caused the leading and trailing spark plugs to be fired in a backwards order. In other words, the trailing spark plugs fired first. These problems were corrected but their effect on the data remains unknown. Therefore, all comparisons of data are made under like conditions. For example, the data gathered from testing the engine with insulated rotors is compared with data gathered from testing with the insulated intermediate housing (with correct ignition in both cases). The baseline test is compared with the insulated intermediate housing test when both had incorrect ignition.

\subsection{Task II Thernal Analysis}

On April 1, 1987 a subcontract was let to (Appendix D) ADAPCO, Inc. for the thermal analysis on the 1007R engine. The purpose of this analytical effort was to determine the structural implications of an "adiabatic" direct-injection stratified charge (DISC) rotary engine. The analysis was to predict a thermal history to provide the basis for calculating the distortion, allowable clearances, and thermal stresses. These calculated stresses were then to be combined with rotating stresses and pressure loading stresses to provide input for component design.

The method for conducting this analysis was to be as follows:

A NASA to furnish 1007R drawings and test data to ADAPCO,

B NASA to furnish MIT stratified charge combustion model (DISC),

C ADAPCO to incorporate 1007R geometry and run the MIT Model to generate boundary conditions, 


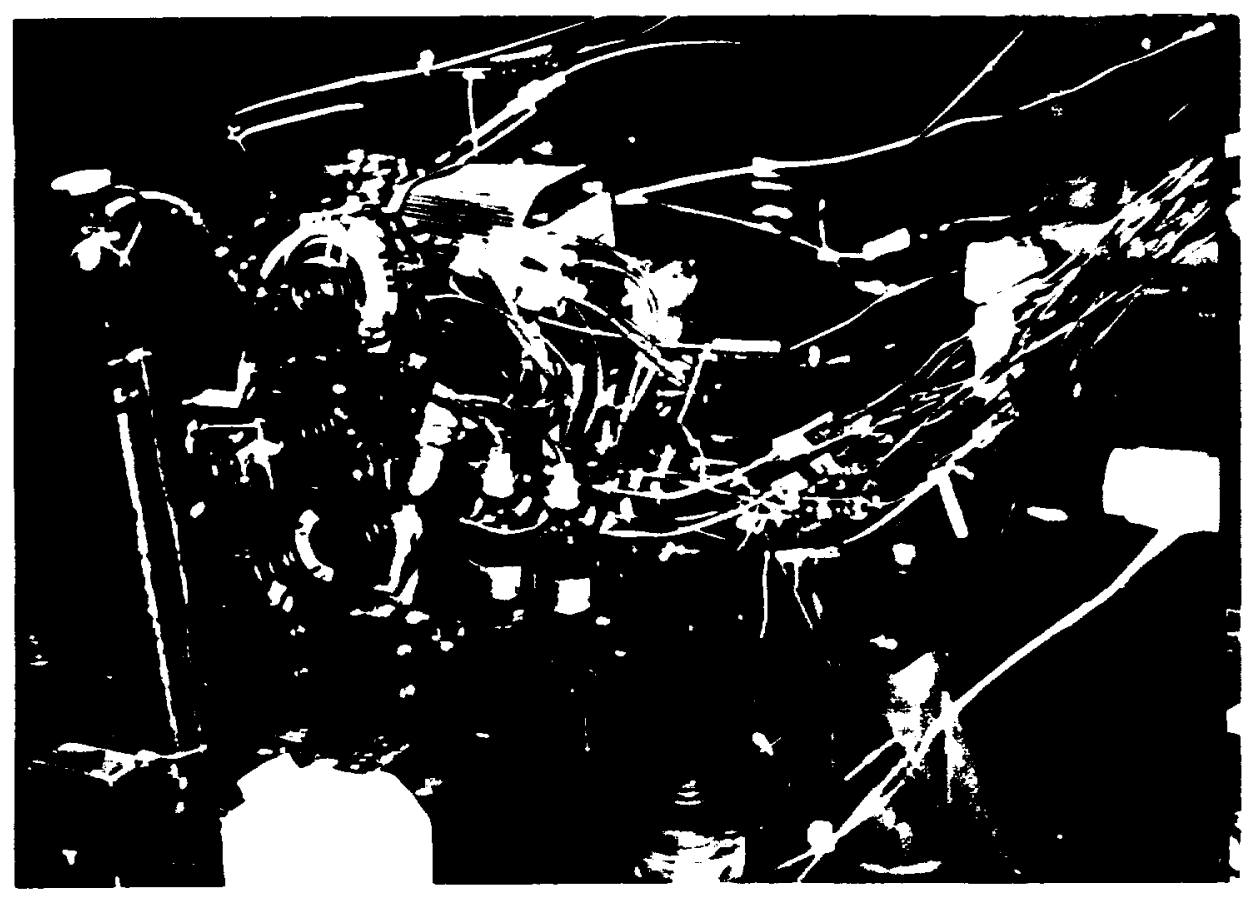

$\mathrm{AI}-\mathrm{C} / 111-2 \mathrm{~A}$

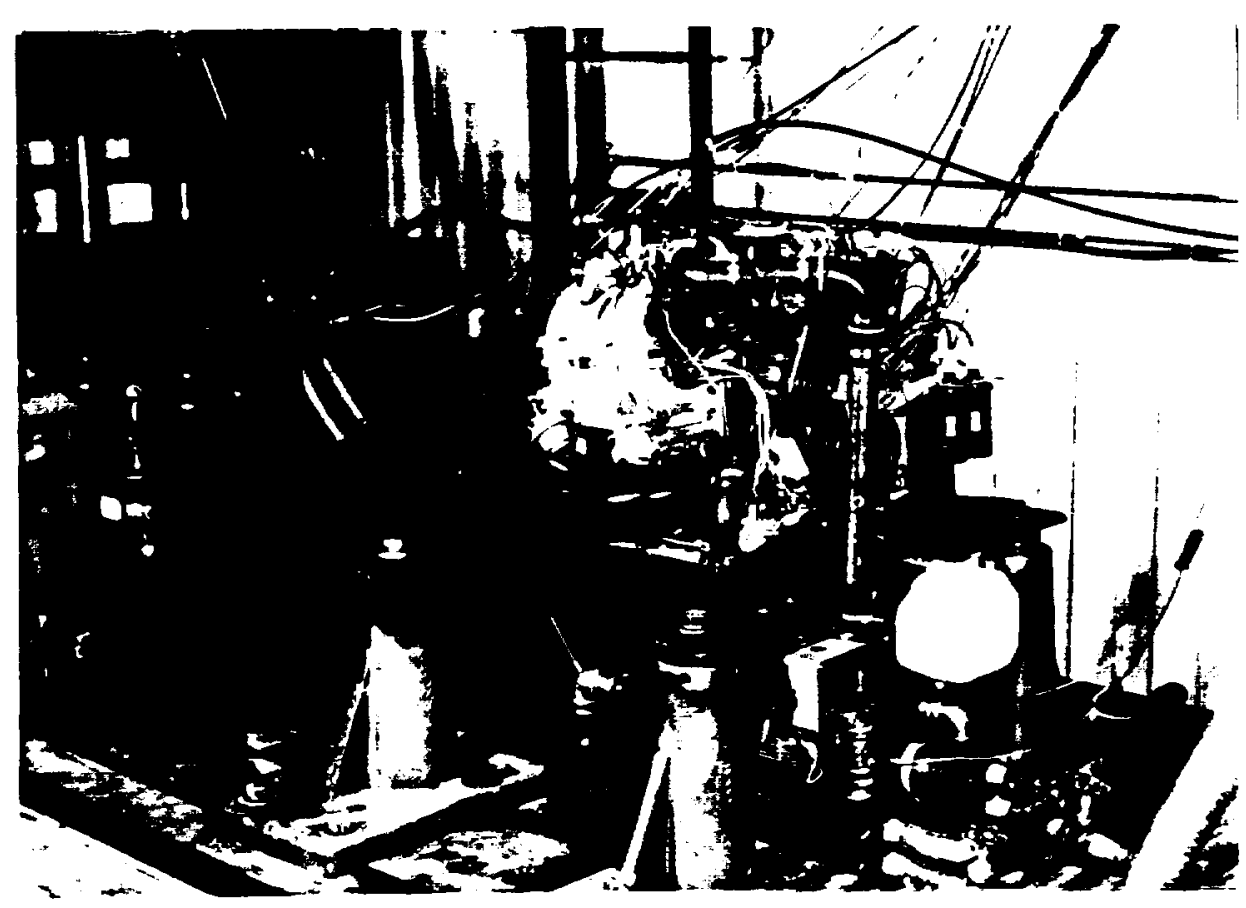

$A I-C / 111-6 A$

Figure 5.1.3-1. Mazda Engine Ready for Baseline Testing. 
D ADAPCO to use John Deere data to verify model,

E ADAPCO to generate FE model of $1007 \mathrm{R}$ rotor and rotor housing,

F ADAPCO to use boundary conditions from $C$ and run FE model, and

G ADAPCO to prepare report.

A copy of ADAPCO's final report number 44-01-001 dated March 4, 1988 entitled "Heat Transfer and Structural Analysis of a Thermal Barrier Coated Direct Injection Stratified Charge Rotary Engine" is hereby submitted to NASA as appendix to this report.

The conclusion of ADAPCO's report was that the insulated rotor was the most likely component to survive in the adiabatic engine (though it showed high levels of stress in the coating around the "lip" of the combustion bowl). The stock aluminum 1007R rotor housing (coated with a combination of insulation and wear surface coating) when run with coolant was predicted as having a likely chance of failure. Due to the difficulty of applying thermal barrier coatings on aluminum, a coated cast iron rotor housing was modeled as an alternative to aluminum. The simulation predicted that the only outcome of using a coated cast iron rotor housing in a uncooled engine was coating failure. This failure was chiefly predicted because of the thermal expansion mismatches between the insulative coating on the trochoid contour and the cast iron.

\subsection{Task III Adiabatic Component Design}

Adiabatic component design was included in the subcontract with ADAPCO. Once ADAPCO had completed a computer simulation run of the baseline 1007R engine, ADAPCO was to proceed and modify the models for combustion and the FE models for the rotor and rotor housing to include selected low-heat-rejection conditions. These results were then used in an interactive manner to design insulated 1007R components. These preliminary designs were then coupled with the knowledge gained from screening tests in the Mazda engine.

Drawings, completed by Adiabatics, of the final modifications to the 1007R parts are included (Section 5.7 Prototype Engine - Procurement/Assembly - NASA 1007R).

\subsection{Task IV High Temperature Apex/Side Seal Tribology}

This Task is to evaluate and procure candidate apex seals, side seals, and high-temperature lubricants to be tested in the Mazda engine for later inclusion in the $1007 \mathrm{R}$ engine. The procurement of the apex and side seals is summarized in Table 2. The initial work performed in this task was to find material combinations which would be most likely to survive the harsh conditions encountered in a high-temperature engine.

Based on past experience with high temperature reciprocating piston engines, chrome-oxide or chrome-carbide coated piston rings rubbing against zirconia thermal-barrier coated liners densified with chrome oxide are the prime candidate materials.

Efforts were then spent trying to procure side seals and apex seals micropocketed and coated with thin $[(0.051 \mathrm{~mm}(0.002$ inch) to $0.127 \mathrm{~mm}(0.005$ inch)] layers of chrome oxide and or chrome carbide. Unfortunately, vendors could not be located to supply these components. 


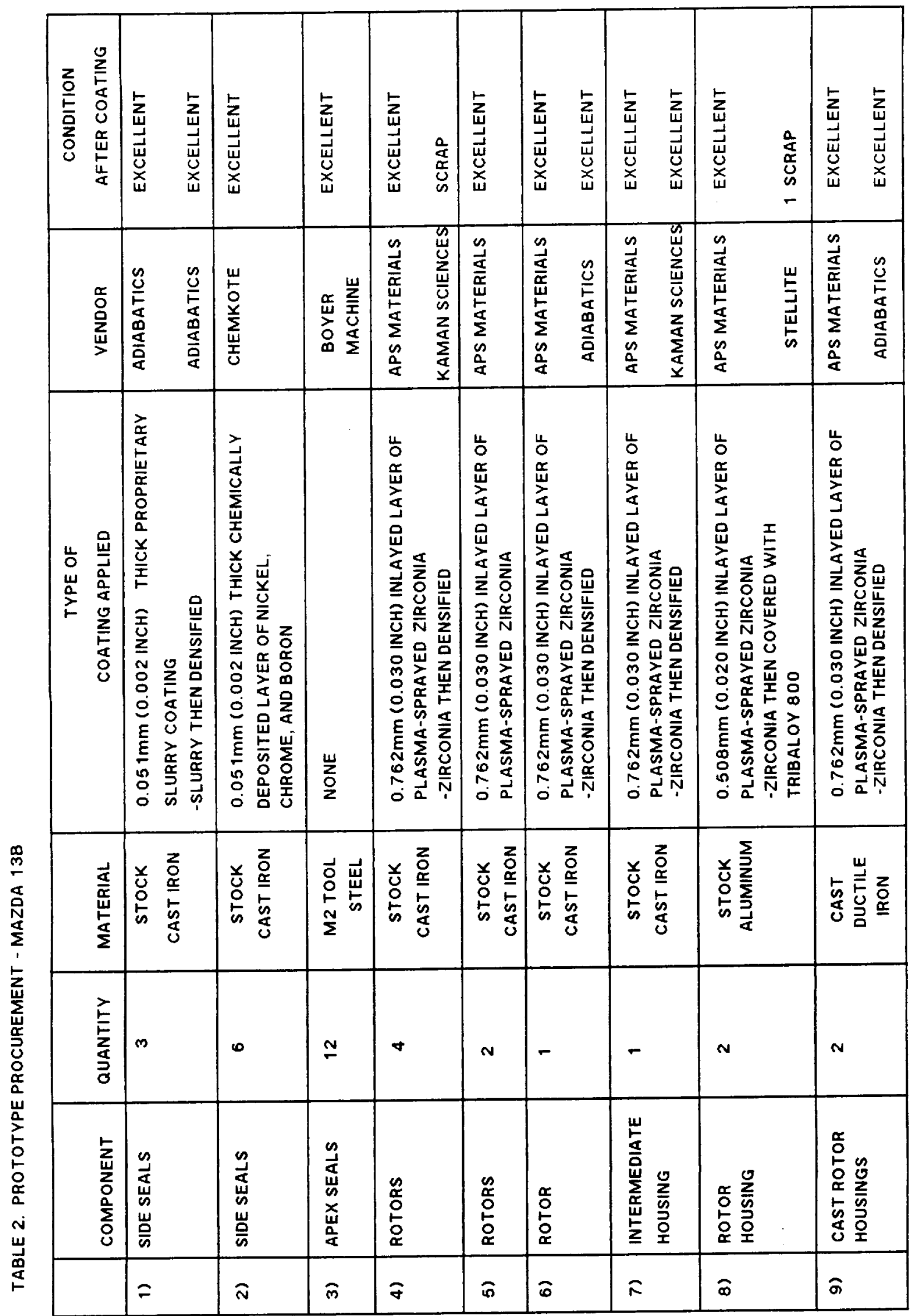


At this point two new approaches were utilized: the first, was an electro chemical coating process, and secondly, a slurry sprayed coating process applied at room temperature and low pressure.

The electro chemically deposited coating chosen for the side seal application was supplied by Cemkote, Inc. of Indianapolis, Indiana. The coating is called "Chem 2" and consists of nickel, chrome, and boron. Since this coating is chemically deposited, its application is very uniform across the entire surface. Before the side seals were coated, the Chem 2 coating was applied to specimens which Adiabatics tested in a wear test rig.

The wear and friction test rig was designed and built as a relatively quick and inexpensive way of screening materials under controlled test conditions. It employs the principle of a roller rotated against an oscillating bar specimen as shown in figure 5.4-1. The flat bar specimen is clamped to a steel bar which is supported by linear/rotary bearings and arranged for linear oscillation of $\pm 6.3 \mathrm{~mm}$ by a motor-driven cam at a fixed $4 \mathrm{rpm}$. The loading of the test specimen on the roller is provided by applying dead weights on the pivoting support structure. The roller is driven by a constant speed electric motor and any desired roller speed can be set by adjusting the variable diameter pulleys.

Test environment control is provided by encasing the roller and test specimen in an insulated enclosure. Electrical heaters built into the walls of the enclosure are thermostatically controlled and the heating of the enclosed air provides a means for test temperature variation of the roller and specimen, up to $538 \mathrm{C}$. In figure 5.4-1 the enclosure is shown operating open-ended with connections to a coal burner and a suction fan. This arrangement is used to test materials in the environment of coal combustion products. The test temperature is regulated by the use of the in-line damper to control the flow rate of the combustion air and the heating coils.

The coal burner can also be replaced by a gas burner or a feeder of other environment contaminants, like coal powder without combustion.

The torque required to drive the roller is measured by an in-line torque meter and is continuously recorded on a chart recorder. The temperatures of the roller and the test specimen are monitored by thermocouples installed as shown in figure 5.4-2, and also recorded on the chart recorder. A drawing of the assembly of the major components of the friction and wear test rig is shown in figure $5.4-3$.

The duration of a test or any event during the test is determined from the chart paper speed, selected as needed. From this recording and the load applied by weights, the force between the roller and the specimen is evaluated, the coefficient of friction can be calculated at any time during the test.

Wear values are obtained by measuring the weight loss during the test. This is done by weighing test parts before and after a test. A balance of 0.0001 gram resolution is used to weigh the specimens. The accuracy of the wear measurement is dependent on the amount of weight loss produced and the resolution of the scale. Hence, to ensure acceptable accuracy, the duration of tests was varied depending on the wear rate of the materials tested. Most of these tests were run for 18 hours while a few were as short as 15 minutes [2]. 


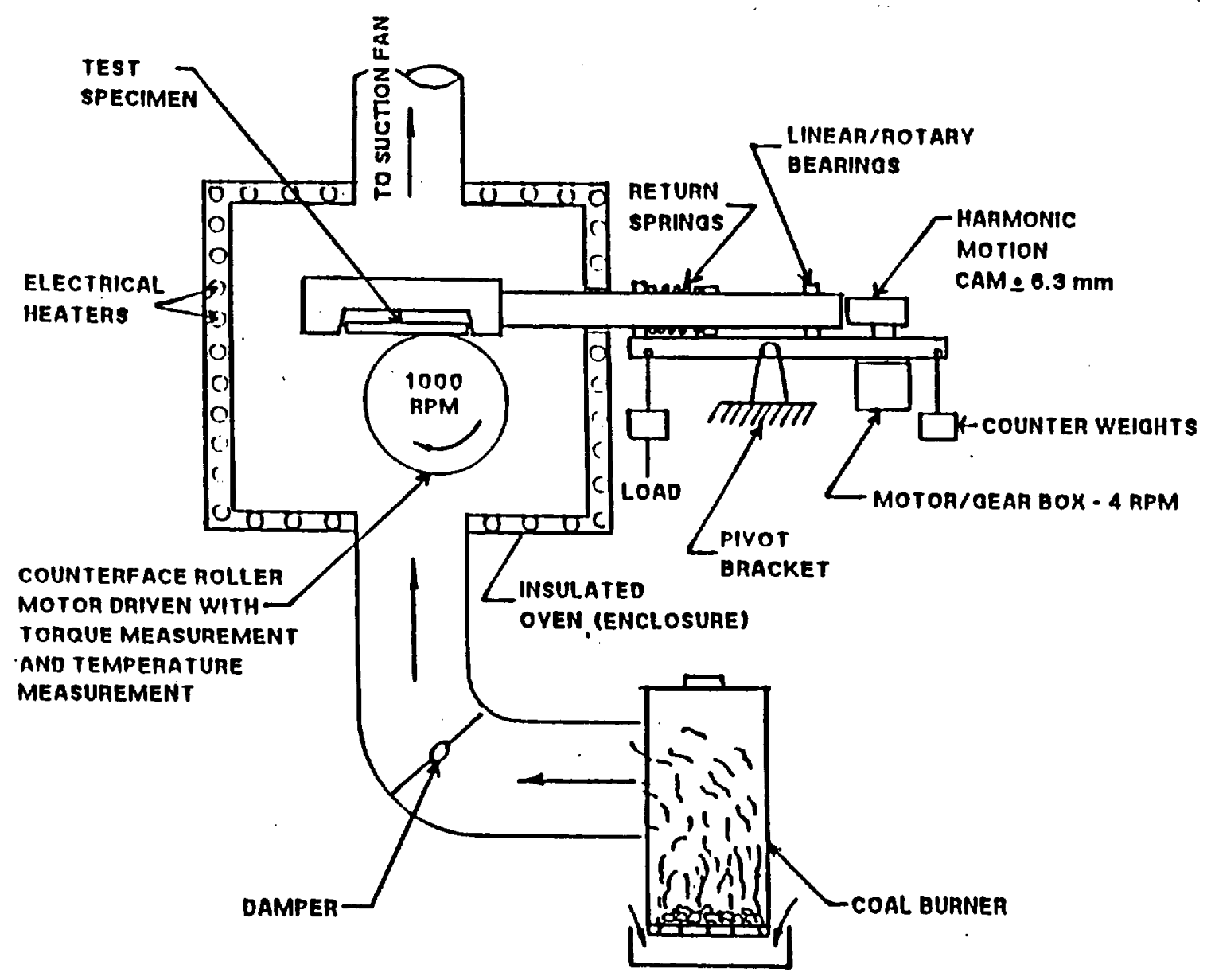

Figure 5.4-1. Schematic Drawing of Friction and Wear Test Rig. 

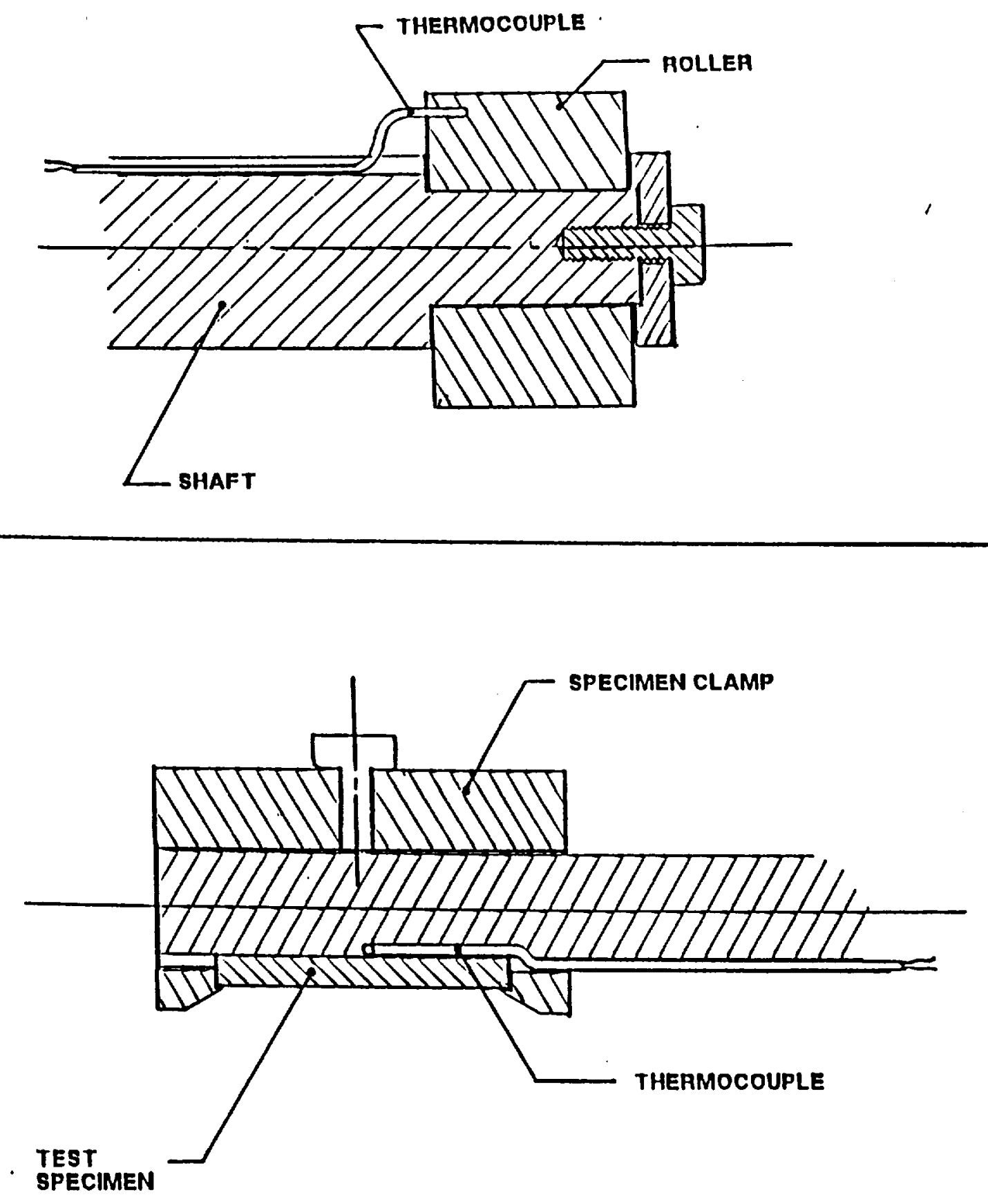

Figure 5.4-2. Thermocouple Installation for Roller and specimen Temperature Measurement. 


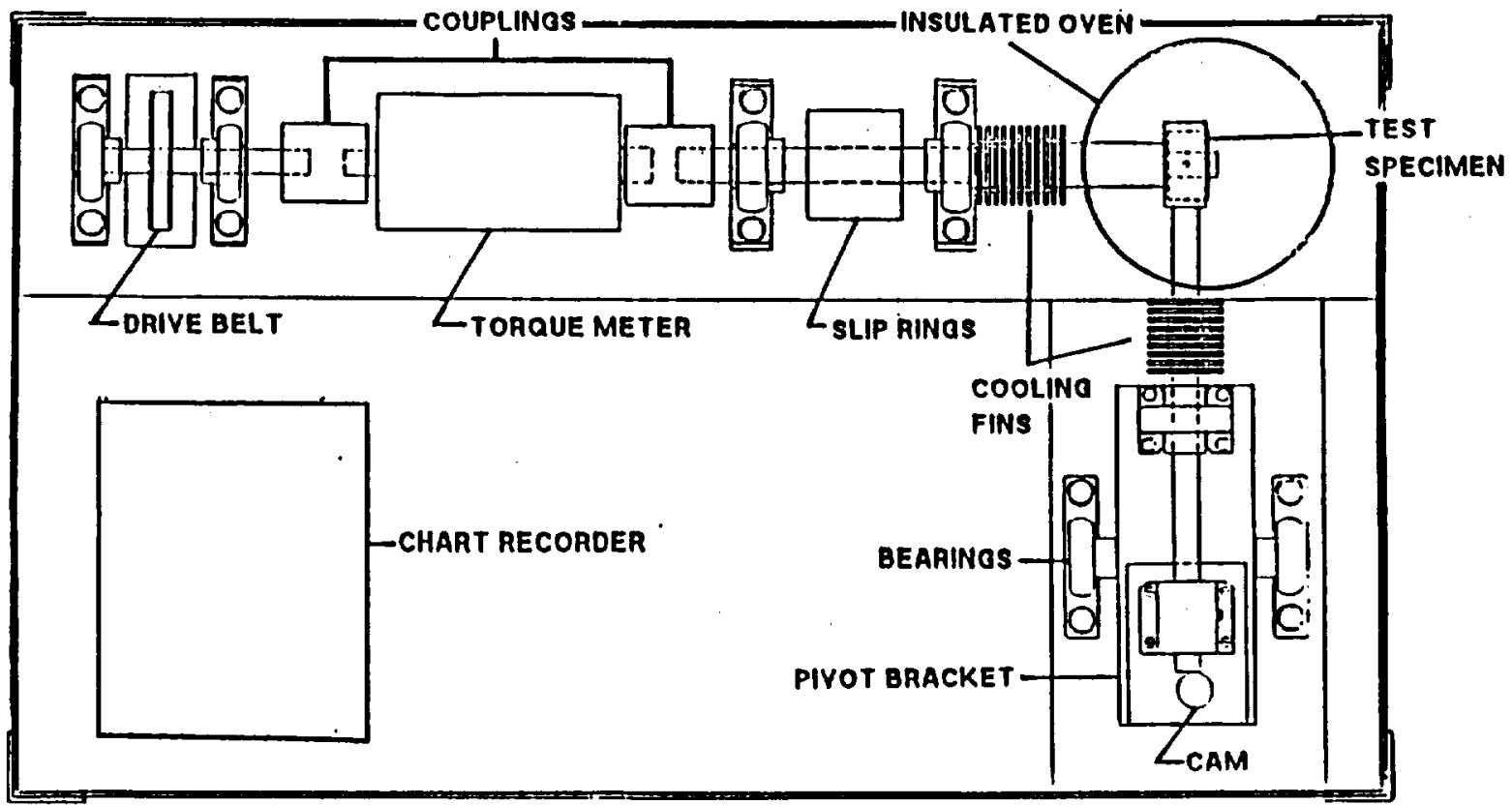

Figure 5.4-3. Drawing of Friction and Wear Test Rig Assembly. 
The test results revealed that the Chem 2 is not very wear resistant but offered a very low friction coefficient.

A second set of rotor side seals was coated with a slurry coating developed by Adiabatics, Inc. The chrome molly chemical slurry type coating was sprayed at low velocity and room temperature to approximately a $0.051 \mathrm{~mm}$ (.002 inch) thickness. This coating is proprietary; therefore, its constituents are not 1isted. The results of the wear test showed this coating to be very resistive to wear.

For apex seals M2 tool steel was selected based on many tests of material specimens on Adiabatics' wear test rig, M2 was selected based on its resistance to wear and its high temperature capability. Two sets of apex seals were made from M2 tool steel by Boyer Machining, Inc. of Columbus, Indiana.

The last area of Task IV was selecting and procuring candidate high-temperature lubricants. A major portion of the Mazda testing was performed using a synthetic lubricant called SDL-1 which is sold through Bonneville Lubricants of Idaho Falls, Iowa.

This oil was chosen based on experience with reciprocating piston engine testing at Adiabatics.

Throughout all the coated component screening tests, oil temperatures varied between $93.33 \mathrm{C}(200 \mathrm{~F})$ and $126.67 \mathrm{C}(260 \mathrm{~F})$. No evidence of oil break down was noticed.

The stock John Deere 1007R apex seals and side seals will be suitable for running against the Tribaloy 800 coating on the aluminum side and rotor housing because Tribaloy 800 has excellent tribological characteristics and is compatible with the current John Deere seals. Therefore, no special side or apex seals were procured.

\subsection{Task V Prototype Engine-Procurement/Assembly-Mazda 13B}

The following is a listing of the low-heat-rejection components along with a description of how they were made.

\section{5 .0 Rotor}

The rotor modification was application of thermal barrier coating to the combustion faces. The rotor combustion faces, with the exception of a $9.5 \mathrm{~mm}$ ( 0.375 inch) land at each apex (such that the apex seal was fully supported by the parent rotor material) and a $0.762 \mathrm{~mm}(0.030$ inch) land along the side lands of the rotor, were machined to remove $0.762 \mathrm{~mm}(0.030$ inch) of material. A $0.762 \mathrm{~mm}$ ( 0.030 inch) inlaid thermal barrier coating consisting of a $0.127 \mathrm{~mm}$ $(0.005$ inch) layer of plasma-sprayed NiCrAlY bond coat covered with a $0.635 \mathrm{~mm}$ ( 0.025 inch) layer of plasma-sprayed zirconia was then applied onto the machined inset on the faces of the rotor. With the coating applied, the high spots were removed and the coating then densified with the Kaman KaRamic Process. In doing this, an impenetrable barrier was formed which protects the bond coat. A drawing detailing this coating procedure is shown in figure $5.5 .0-1$. 


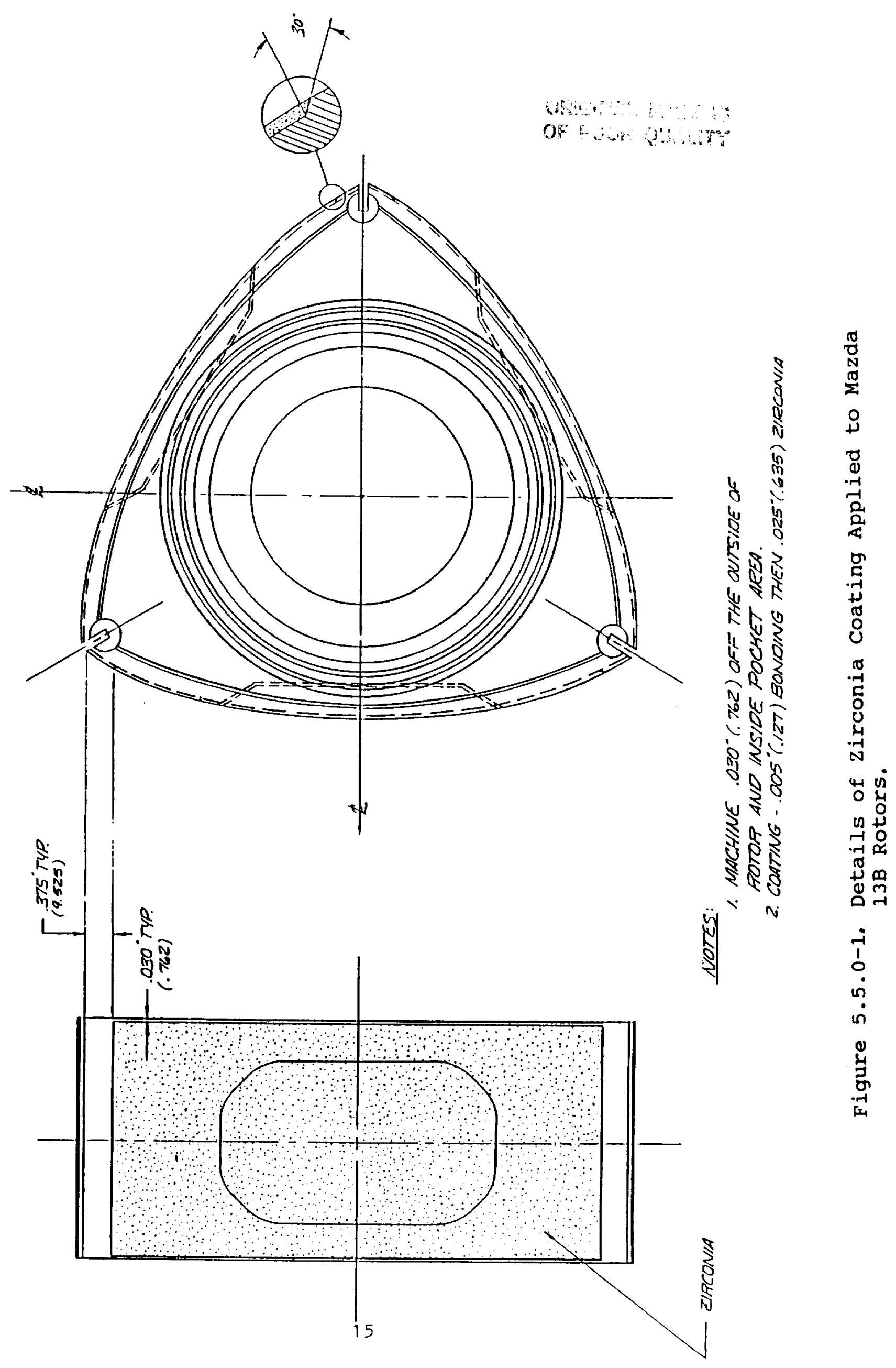


Two (2) rotors were processed as described above. During the densification process the coating on both rotors failed. Kaman Sciences Corp., who densified the pieces, claimed coating failure was caused by a problem with their oven. Densification is a process of filling the zirconia porosity near its outer boundaries with chrome oxide, thereby forming a barrier which protects the bond coating. To do this, a liquid chemical is applied to the zirconia and allowed to penetrate. Next, the whole part is heated to $537.8 \mathrm{C}(1000 \mathrm{~F}$ ) at which time the liquid chemical is converted into chrome oxide. Kaman said that oven temperatures reached $792.2 \mathrm{C}(1458 \mathrm{~F})$ which not only caused the coating to "pop off" but as discovered later, caused the rotor gear to lose its hardness. Since the gear is not replaceable these rotors could not be re-coated, and were therefore scrapped.

Two more rotors were machined and coated with plasma-sprayed zirconia. They were sent to Kaman Sciences for densification where, after one temperature cycle, the coating popped off (shown in figure 5.5.0-2) in the identical locations as before. Kaman claimed the problem this time was caused by "bad coating" and not their processing.

These last 2 rotors were recycled. The damaged coatings were sandblasted off and a thermal barrier coating was reapplied. These rotors were later tested in the engine without receiving densification.

Because zirconia is porous, the bond coat is susceptible to chemical attack in the engine which results in a shorter life. Therefore, one more attempt was made at densification. This time major changes were made in both the design of the rotor and the densification process itself. In every case the coatings failed in the same areas - along the lip of the combustion chamber (see figure 5.5.0-2). Therefore, a design change was made whereby a thin band of parent material was left untouched during machining around the 1 ip of the combustion chamber (see figure 5.5.0-3). A new low-temperature process developed by Adiabatics which is not only better for the parts but it is non-toxic as well was applied. Through this combination of the 1 ip design and the low temperature densification a first attempt provided one Mazda rotor successfully coated and densified. This rotor is shown in figure 5.5.0-4.

As a result, 2 different kinds of insulated rotors were successfully procured for testing in the $13 \mathrm{~B}$ engine; firstly, 2 insulated rotors with undensified zirconia, and secondly, 1 insulated rotor densified by Adiabatics, Inc. incorporating a combustion chamber 1 ip.

\subsubsection{Side Housing}

The initial approach to the side housing was to apply low-heat-rejection technology to only one side housing face in each combustion chamber by applying the insulation to both faces of the intermediate housing. To apply the thermal barrier coating, $0.762 \mathrm{~mm}$ thick ( 0.030 inch) of parent material was machined from both sides of the intermediate housing. A lip of parent material was left untouched during the machining operation around both the crankshaft hole and the intake port. This resulted in a coating which would be totally inlayed. Next, a $0.127 \mathrm{~mm}$ thick ( 0.005 inch) layer of NiCrAlY bond coat plus a $0.635 \mathrm{~mm}$ ( 0.025 inch) layer of plasma-sprayed zirconia was applied to the machined areas of the intermediate housing.

The coated housing was then machined back to maintain the original side housing thickness. The zirconia was then densified with chrome oxide by Kaman Sciences 


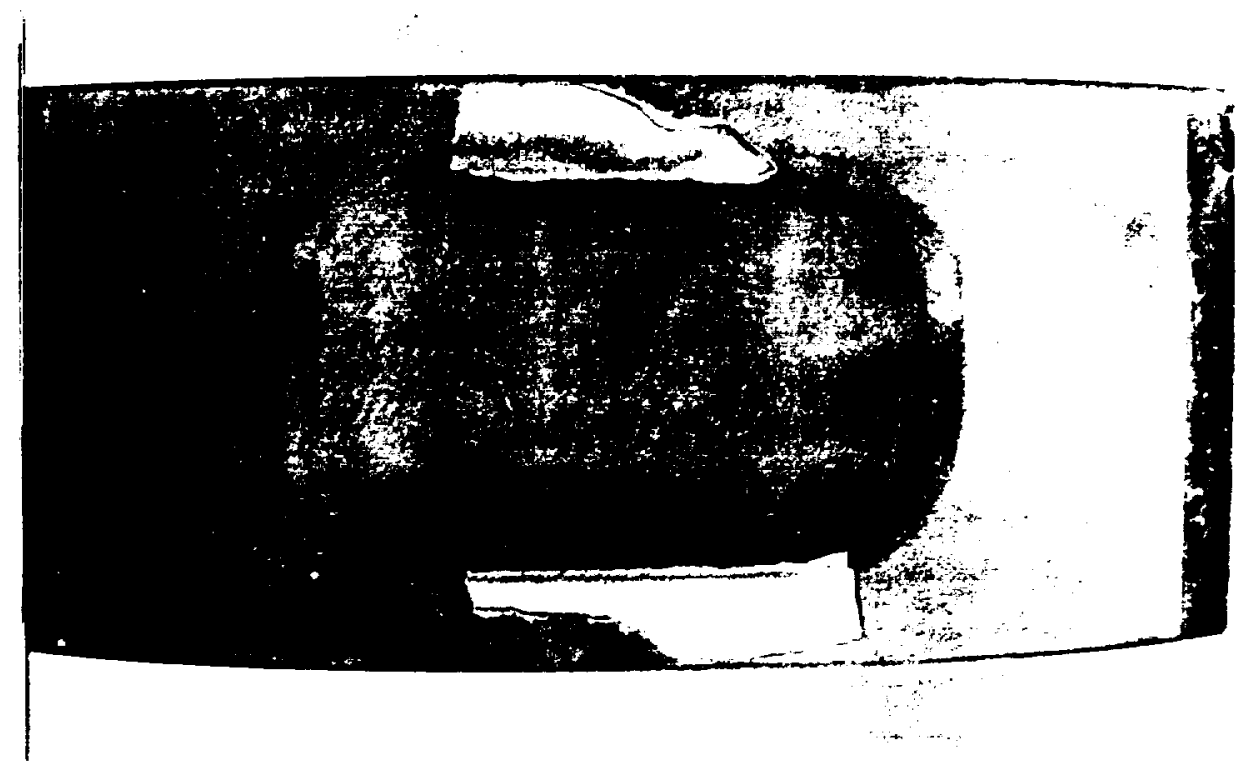

$A I-C / 114-12$

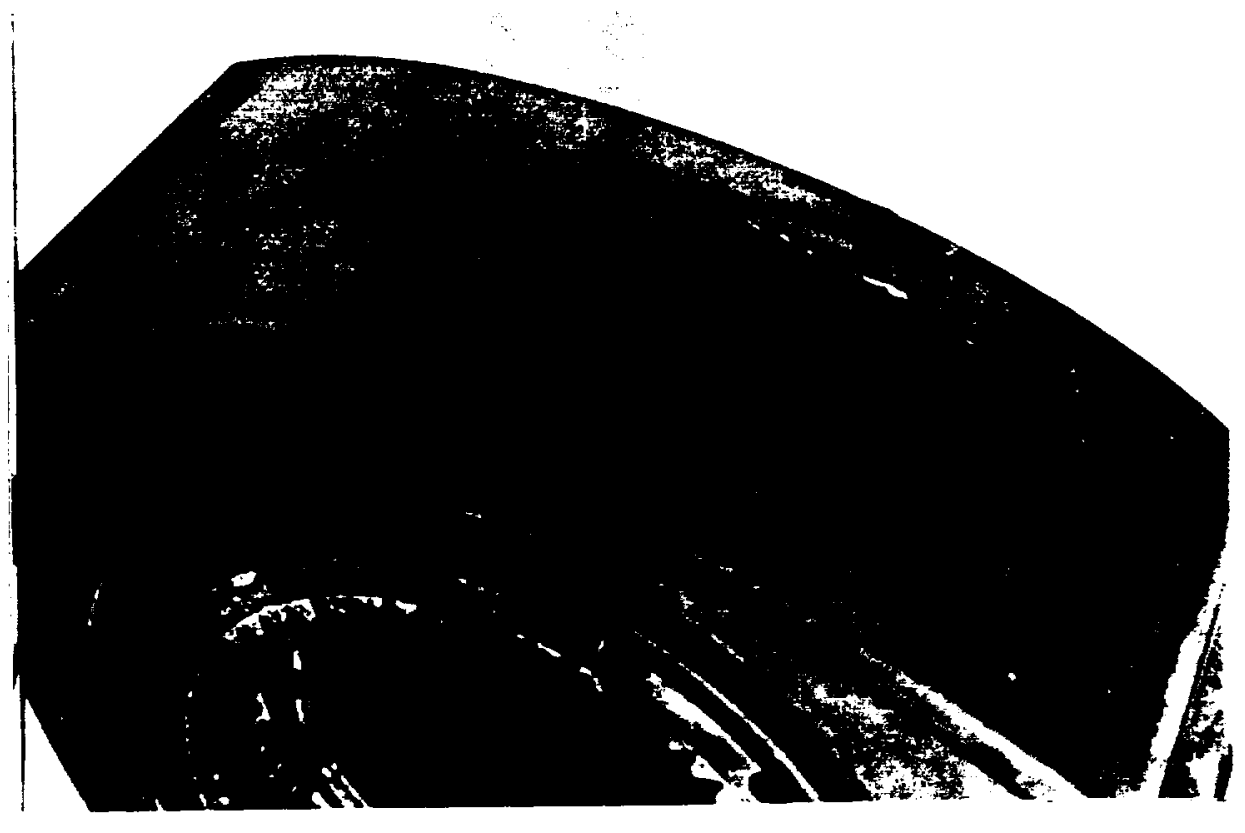

$\mathrm{AI}-\mathrm{C} / 11:-13$

Figure 5.5.0-2. Zirconia coated Rotor After one Densification cycle. 


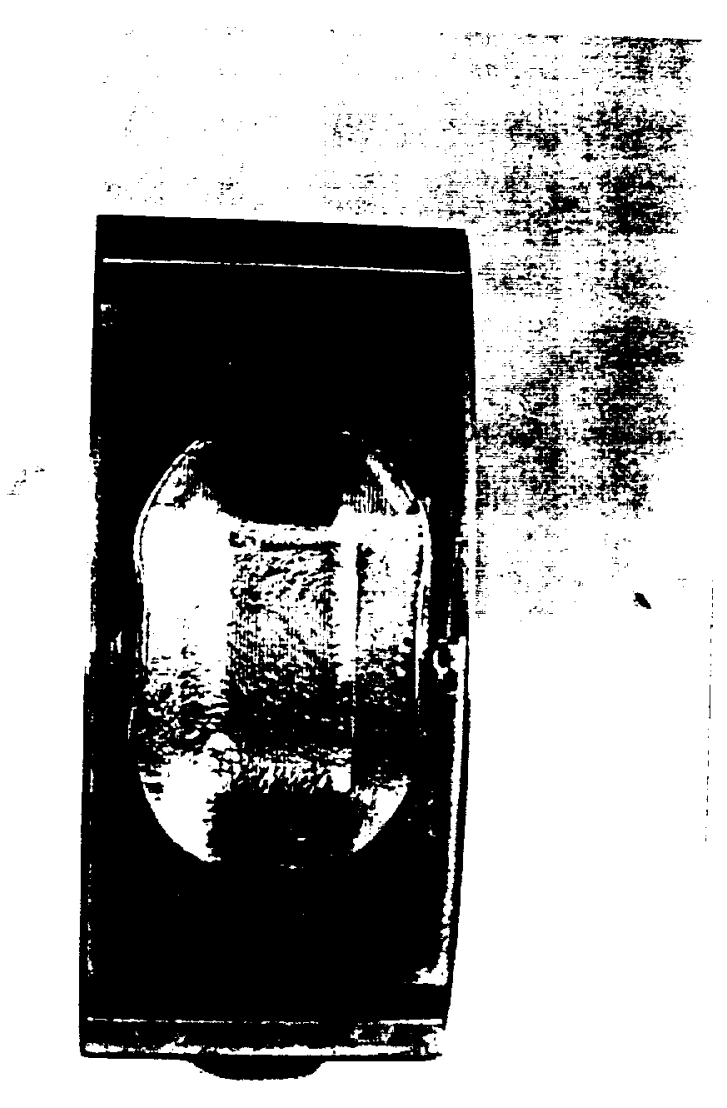

AI $-C / 128-8$ Figure 5.5.0-3. Machined Mazda Rotor with Lip Design Around
the Combustion Chamber. 
ORIGINAL PAGE IS

OF. POOR QUALITY

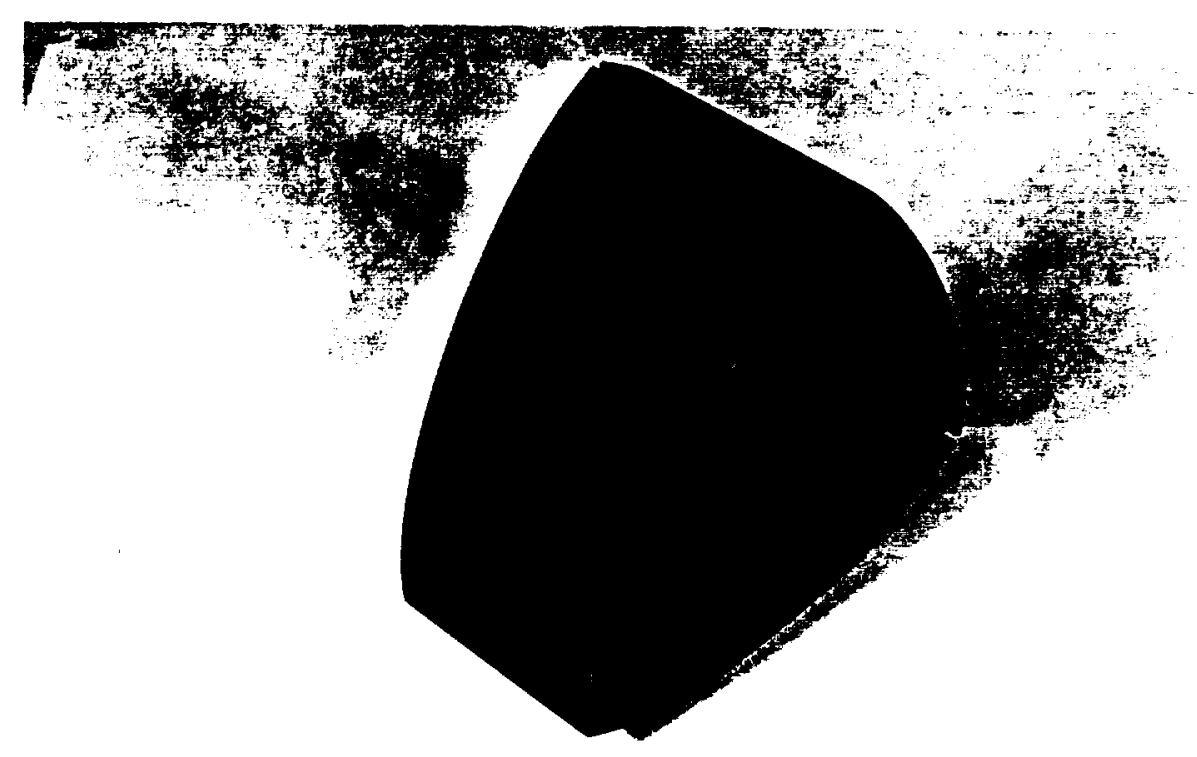

MAZOA 13 B ROTOR COATED 0.030 IN. APS-PSZ ANI LOW CYCLE LOW TEMPERATURE MOOIFIED NC PROCESSING

Figure E.5.0-4. Mazda Rotor After Adiabatics, Inc. Lo: Temperature Densification. 
- successfully. In this case the densification served 2 purposes: 1) as in the rotor application, densification acts to protect the bond coat, and 2) the very hard chrome oxide densification provides an excellent wear surface which is needed since the rotor side seals rub against the thermal barrier. All experience with reciprocating piston engines reveals that this densification process provides the best wear characteristics when applied on cylinder liners. After densification the housing was lapped to a surface roughness of 20 micro-inches. Ideally a surface roughness of less than 10 micro-inches was desired but could no be obtained. As a result of the difficulty during the lapping, the finished coating thickness was $0.508 \mathrm{~mm}(0.020$ inch) instead of $0.762 \mathrm{~mm}(0.030 \mathrm{inch})$. A drawing detailing the coating process is shown in figure 5.5.1-1.

\subsubsection{Rotor Housings}

This component presented the greatest challenge to effectively reduce its heat rejection. The rotor housing material for both the Mazda and the 1007R engine is aluminum (the Mazda side housings are cast iron) which means that the existing technology for cast iron reciprocating engine parts can not be used because the temperatures to which the material is subject during processing is in excess of $537.8 \mathrm{C}(1000 \mathrm{~F})$. Therefore, either a different process was required or else the rotor housing must be made of material other than aluminum. Both approaches were followed.

The stock aluminum rotor housing was coated as follows:

1. The housing was sent to Eonic, Inc. where $0.508 \mathrm{~mm}(0.020$ inch) of parent material was removed from the steel trochoid contour.

2. The housing was sent to APS Materials, Inc. where a $0.127 \mathrm{~mm}(0.005$ inch) layer of plasma-sprayed NiCrAlY bond coat plus a $0.381 \mathrm{~mm}(0.015$ inch) layer of plasma-sprayed zirconia was applied to the machined trochoid contour.

3. The coated housing was sent back to Eonic, Inc. where the $0.254 \mathrm{~mm}$ $(0.010 \mathrm{inch})$ of zirconia was ground off each side of the trochoid contour. This step was performed to ensure dimensional correctness and provide room for the wear coating.

4. The housing was sent to Stellite, Inc. where the ground zirconia was coated with more than a $0.254 \mathrm{~mm}$ ( 0.010 inch) layer of Tribaloy 800 which would act as a wear surface.

5. The housing was sent back to Eonic, Inc. for final grinding and lapping to the stock Mazda trochoid contour dimension.

This coating process was selected based on result of friction and wear testing with specimens (rollers) on Adiabatics' wear testing rig. The plasma-sprayed zirconia/Tribaloy 800 combination showed less wear with lower friction than combinations like plasma-sprayed zirconia/chrome oxide or zirconia/chrome carbide. Also, the zirconia/Tribaloy 800 specimen showed excellent adhesion characteristics. Its entire manufacturing process remains cool enough that aluminum is not damaged. 


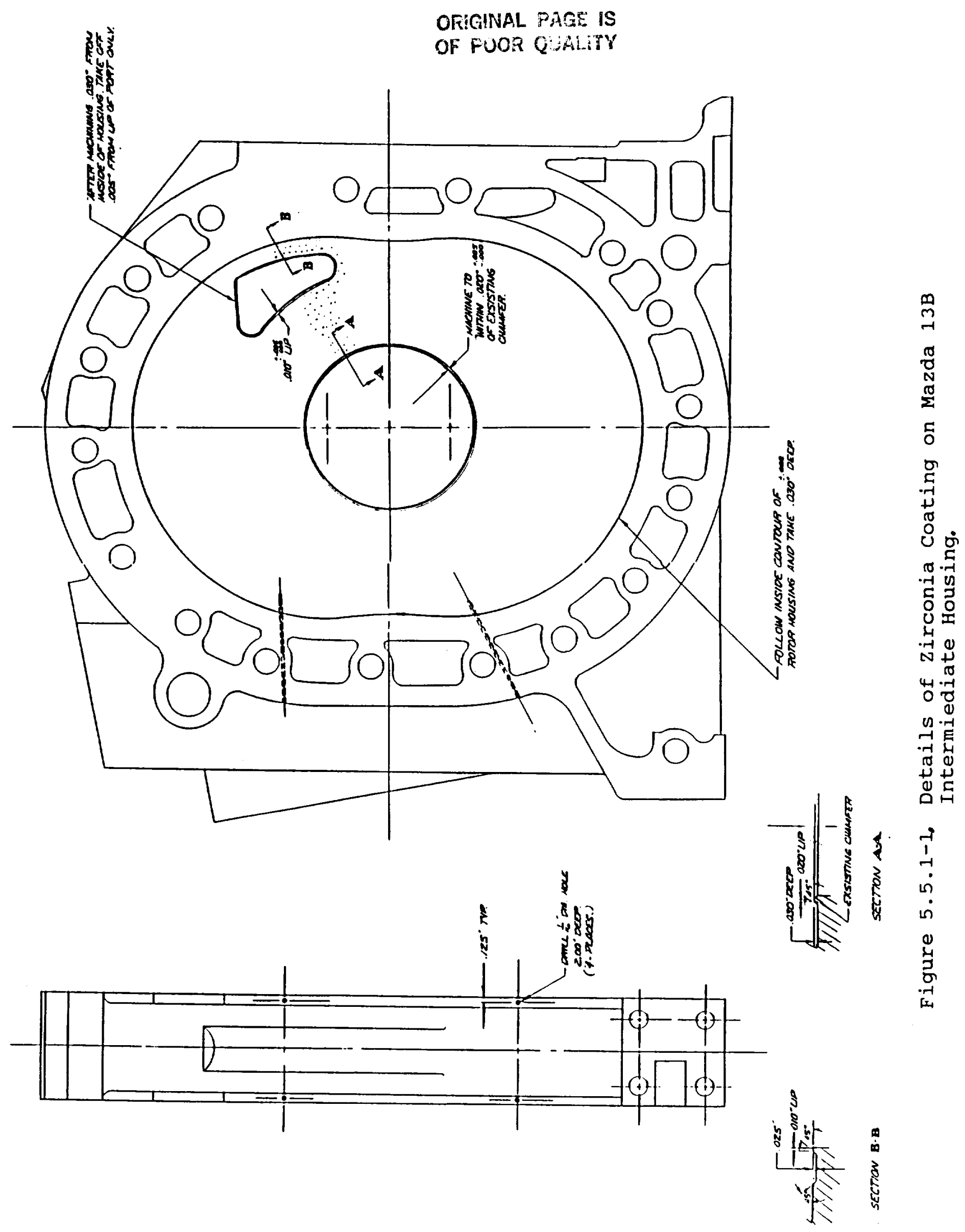


Photographs in figure 5.5.2-1 show the rotor housing after zirconia and Tribaloy 800 application. Two problems were encountered during the coating applications. During step 3 of the above process, areas of zirconia chipped when Eonic ground the zirconia to make room for the wear coating application. These chipped areas were repaired during step 4, application of the wear coating, by filling the damaged areas with Tribaloy 800 .

Shown in figure 5.5.2-2, during step 5 Tribaloy 800 on one rotor housing tore during the grinding operation at Eonic. Therefore, only one of two rotor housings survived the coating operation.

As an alternative approach, Mazda rotor housings cast from ductile iron were made and coated with a thermal barrier coating. The advantage of the cast iron is its ability to withstand high temperatures which means the zirconia can be densified with chrome oxide at $537.8 \mathrm{C}(1000 \mathrm{~F})$.

Essex Casting Company of Columbus, Indiana cast the rotor housings after which they were sent to Eonic to be machined. Eonic machined the oil pan and manifold flats and bolt holes plus exhaust port, tension bolt holes, water seal grooves, and dowel holes. Also, they ground the trochoid contour $0.762 \mathrm{~mm}$ ( 0.030 inch) oversize to allow room for applying a thermal barrier coating. No cooling water passages were machined at this time.

Once the rotor housings were machined, they were sent to APS Materials, Inc. where a $0.127 \mathrm{~mm}(0.005$ inch) layer of plasma-sprayed NiCrAlY bond coat plus a minimum of $0.635 \mathrm{~mm}(0.025$ inch) plasma-sprayed zirconia was applied to the trochoid contour.

Then, the coated housings were sent back to Eonic where the coated trochoid contour was ground and lapped back to stock Mazda dimensions.

The coated and lapped rotor housings, were then densified the with 10 cycles of a high-temperature chrome-oxide treatment. Figure 5.5.2-3 shows pictures of a cast iron rotor housing in the different steps of the coating process.

Once the rotor housings were successfully coated and densified 3 holes were drilled along the top and bottom of the housing which served the purpose of permitting cooling water flow to the standard side housings. These cooling passages (shown in figure 5.5.2-3) are $9.04 \mathrm{~mm}(0.356$ inch) diameter and are smaller than the tension bolt holes. The outside diameter of the cooling passages are located $17.78 \mathrm{~mm}$ ( 0.7 inch) away from the trochoid contour and do very little to cool the rotor housings themselves.

There were 2 problems during the coating process. While Eonic was grinding and lapping the zirconia-coated trochoid contour, small areas of the coating chipped. Adiabatics, Inc. repaired the chipped areas by filling them with a proprietary slurry coating. The other problem with the coating was that cracking occurred throughout the surface area. This was especially apparent after densification. Figure 5.5.2-4 shows the extent of the cracking when checked with dye penetrant. Although it is not an ideal coating, this type of cracking has been seen before and does not mean the parts cannot be used.

A summary of all the components procured for the Mazda 13B engine are listed in Table 2 . 


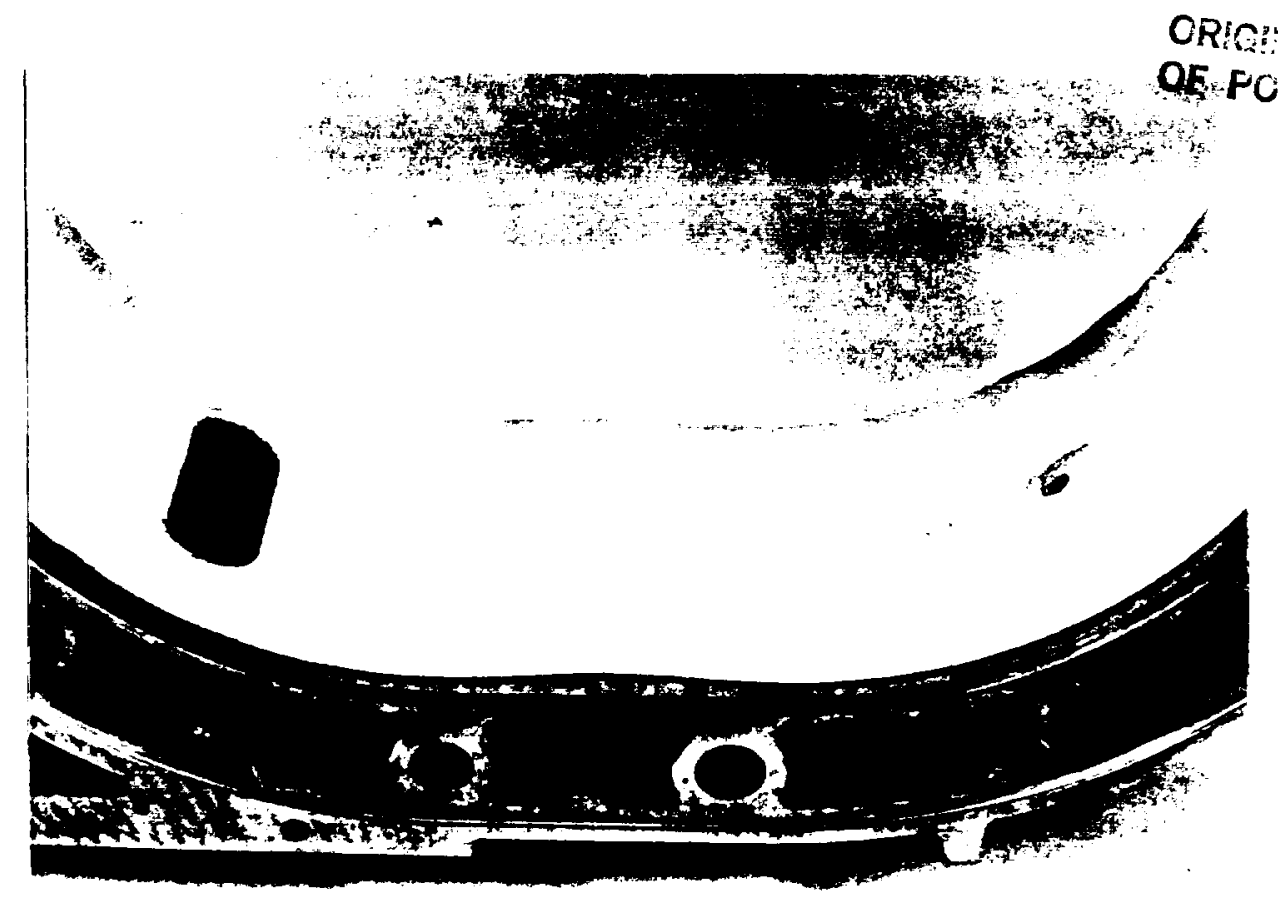

$A I-C / 131-6 A$

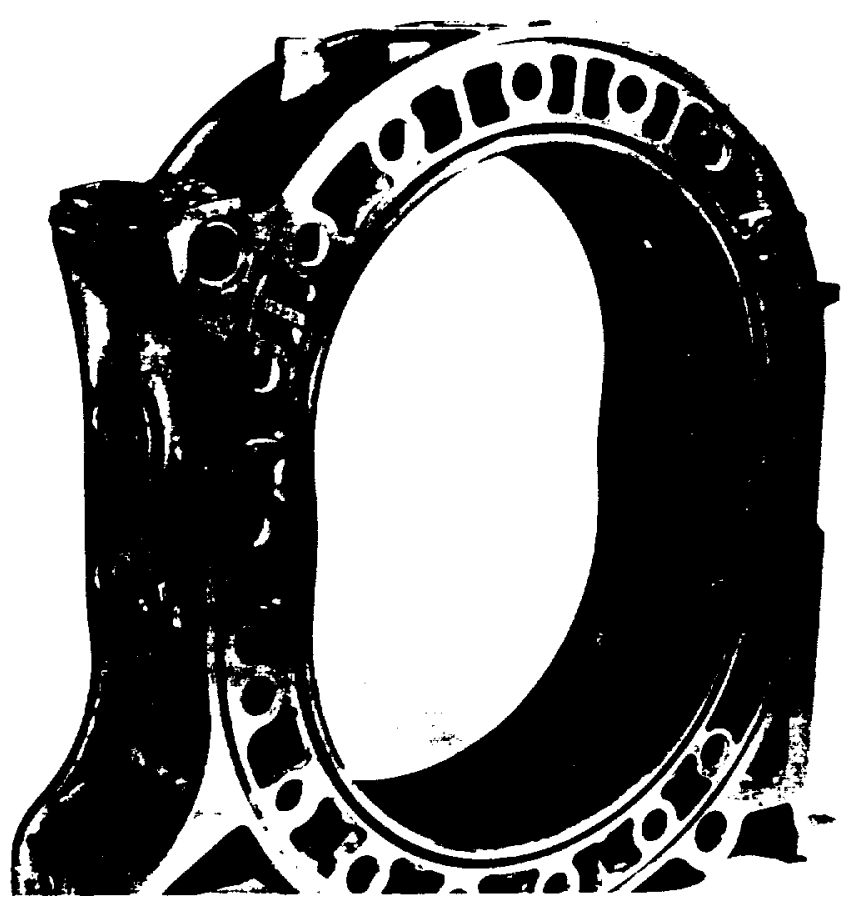

$A I-C / 142-237$

Figure 5.5.2-1. Stock Aluminum Mazda Rotor Housing After Zirconia (a) and Tribaloy 800 (b) Application. 


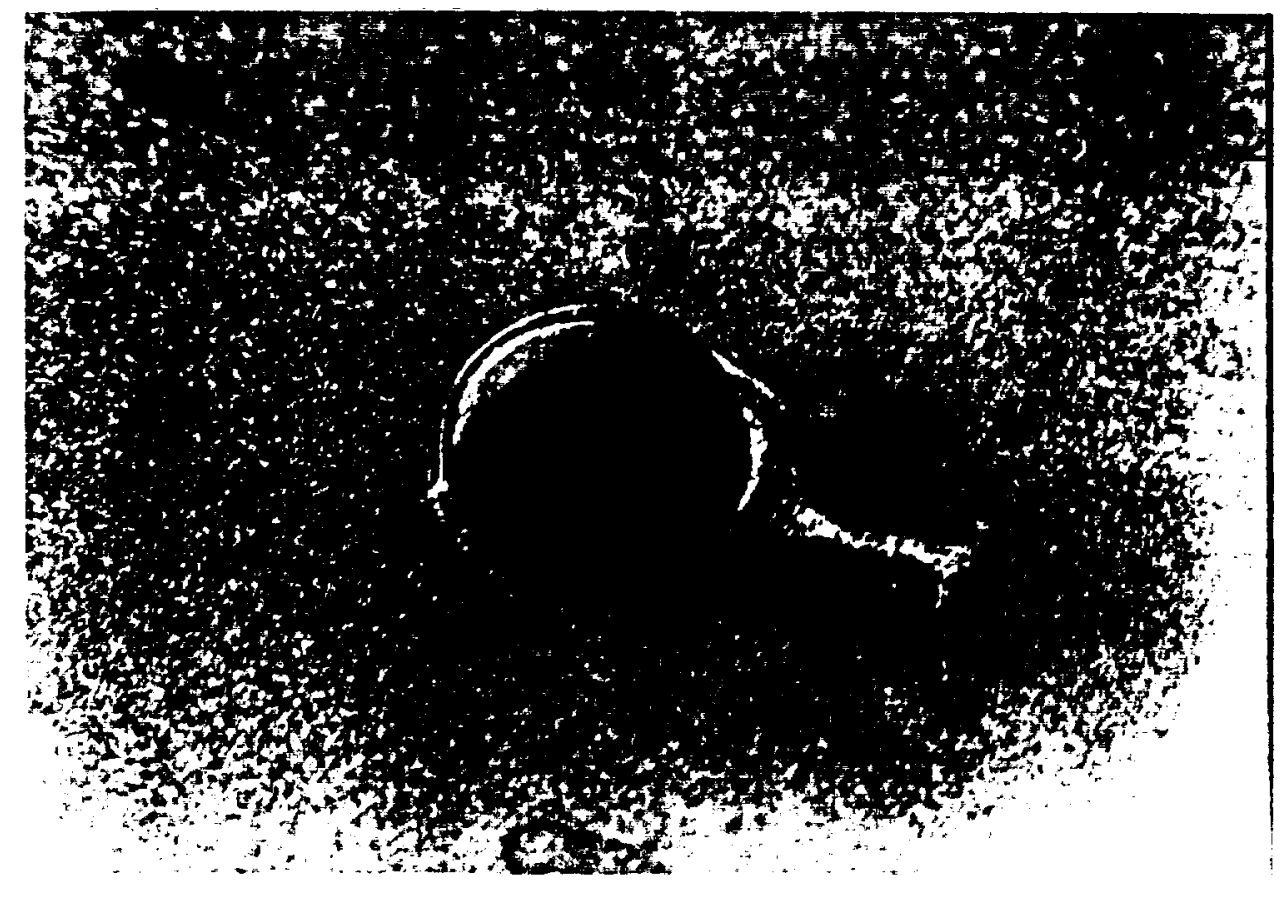

ORIG!NAI. PAGE IJ

OF POOR QUALITY

$\mathrm{AI}-\mathrm{C} / 155-15 \mathrm{~A}$

Figure 5.5.2-2. Failed Tribaloy 800 coating on Mazda stock Aluminum Rotor Housing. 
ORICIMA1 PACE IS

OF PUOR QUALITY

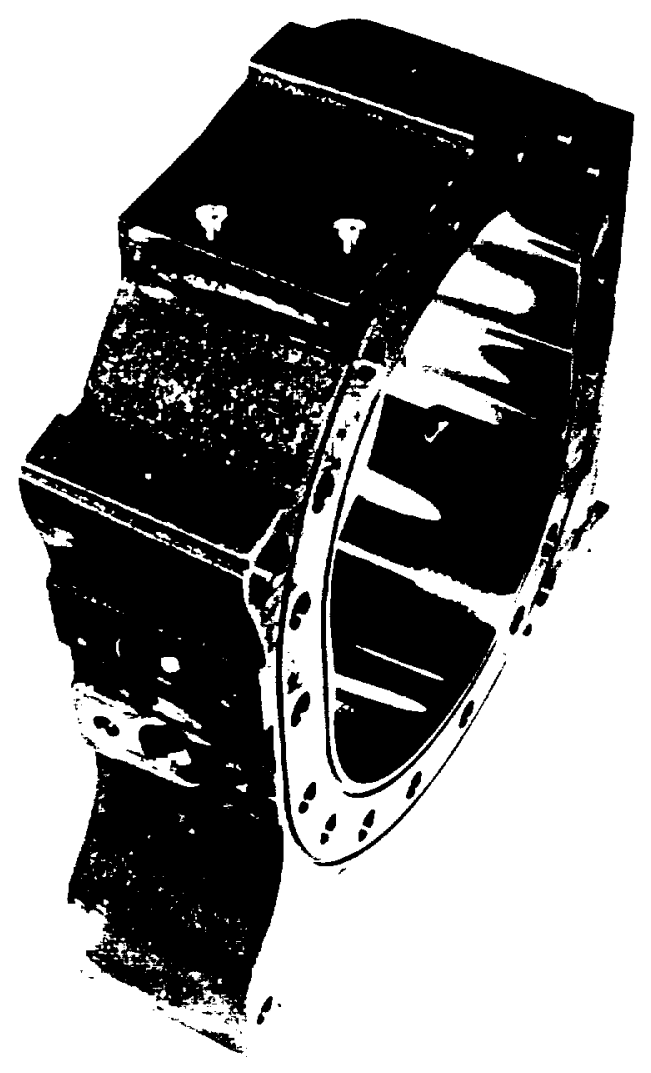

$A I-C: I 3-I 5:$

Figure 5.5.2-3 Cast Iron Rotor Housing After Initial lachining. 


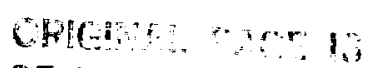

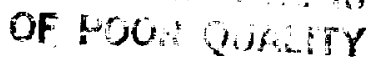

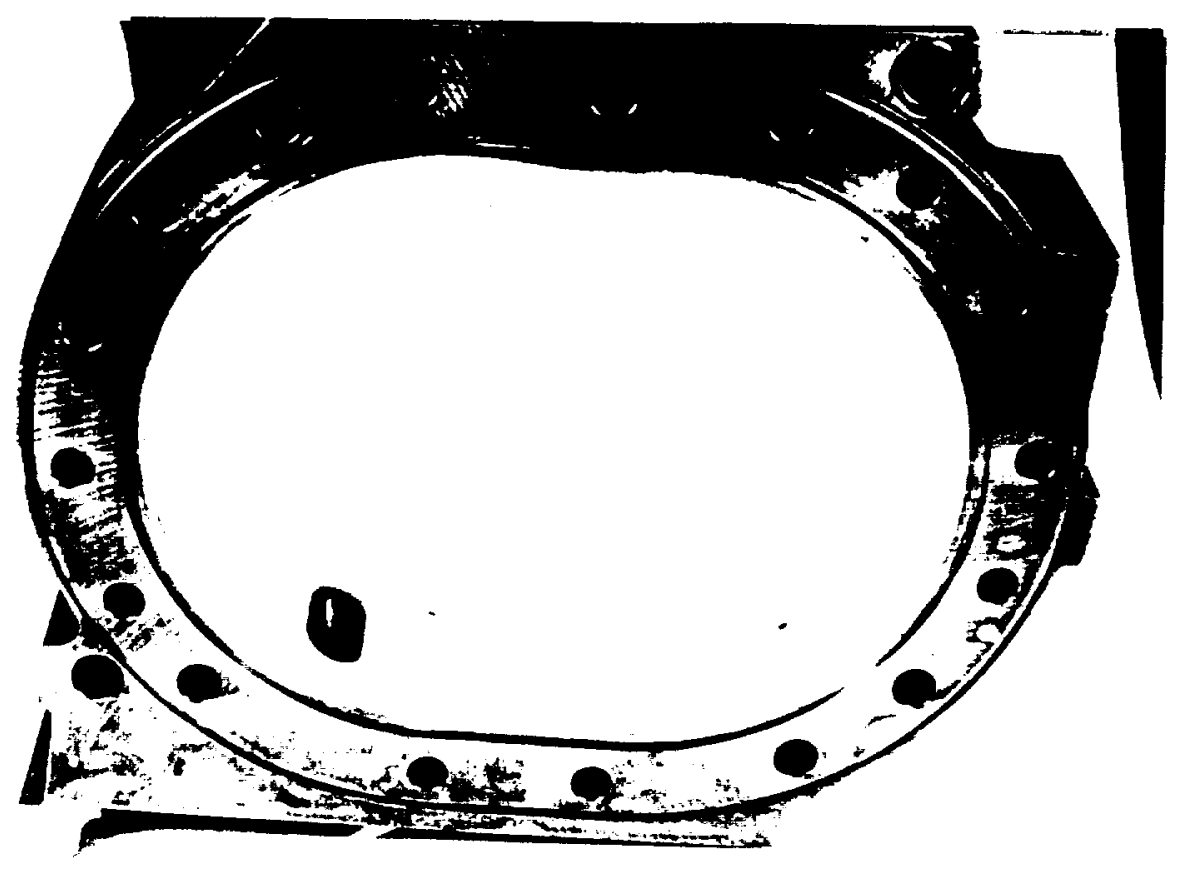

(a)

AI $-C / 134-13$

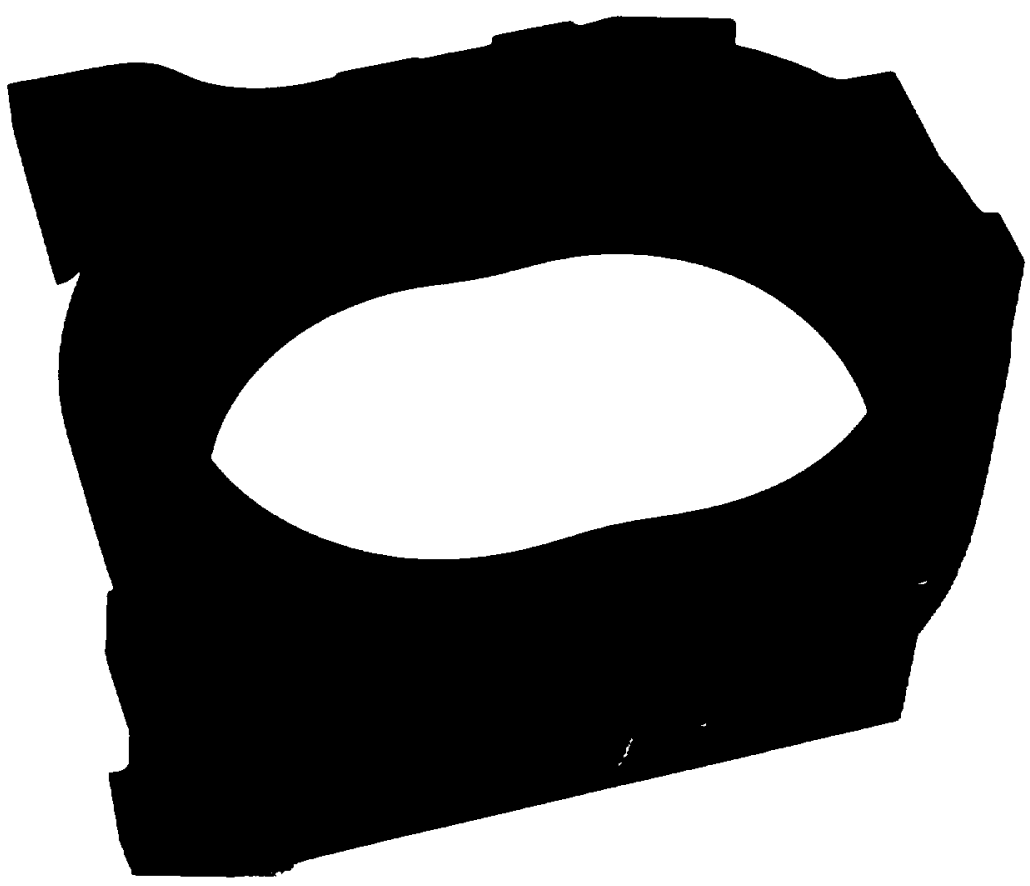

(b)

$A I-C / 131-8 A$

Figure 5.5.2-3 Cont. Cast Iron Rotor Housing After Zirconia Application (a) and After Zirconia Densification. 


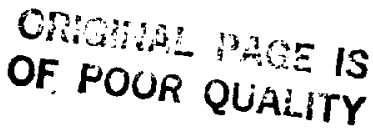

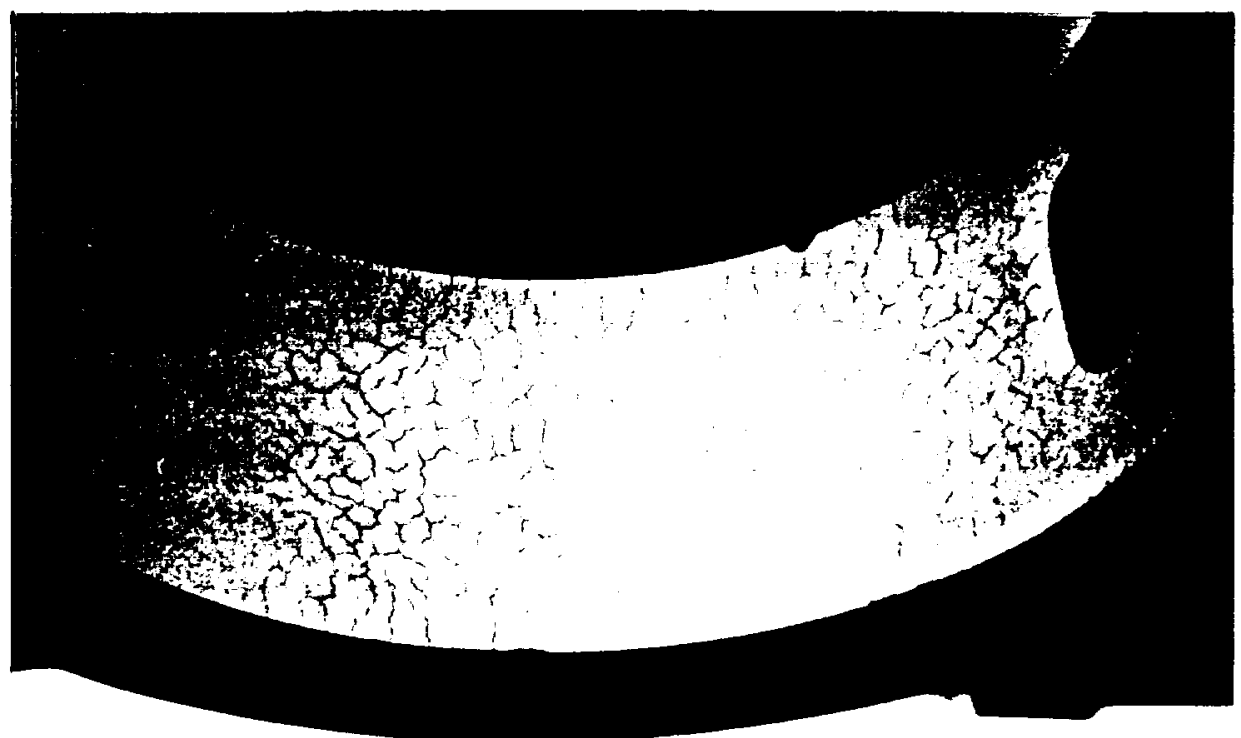

$A I-C / 149-23$

Figure 5.5.2-4. Coated Cast Iron Rotor Housing Showing "Mud" Cracks After Zirconia Densification. 


\subsection{Task VI Fngine Testing}

Engine testing was to consist of separate engine builds and tests for thermal-barrier-coated rotors, rotor housings, and side housings along with a final test of the combination of all low-heat-rejection components assembled together. A minimum of 4 separate engine builds and test cycles were required. The actual number of engine builds was 10 which encompassed 8 different engine configurations. The sections that follow details the events of all the configurations tested with the exception of the baseline test. These tests serve the purpose of testing the individual coated components for integrity and durability.

After the baseline test, the engine test plan described the first thermal barrier component screening as being a test with coated rotors. However, at this time in the program procurement of the thermal barrier coated rotors was meeting difficulties which were discussed in Task V. Therefore, the first thermal-barrier-coated component tested was an insulated intermediate housing.

\subsubsection{Internediate Housing}

After the baseline test, the Mazda engine was disassembled as specified in the Mazda shop manual. While disassembled, all the components were inspected as specified in the Mazda shop manual. A list of the measurements taken can be seen in Appendix E. Before reassembly, the standard intermediate housing was replaced with the coated housing. New stock side seals and button seals were installed against the coated housing. The rest of the engine used the seals and housings which were run during the baseline test. The engine was then reassembled as specified in the Mazda shop manual. The same engine parameters were measured as outlined for the baseline test plus the engine was run for endurance.

The assembled engine was mounted into test cell No. 2 and connected to an Eaton dynamometer via a driveshaft with a one degree offset. Once the engine was mounted the Digalog dynamometer controller was calibrated as specified in the Digalog manual. All other instruments were checked and calibrated to ensure correct readouts.

The engine was then filled with standard coolant and SDL-1 synthetic lubricant. The engine was tested for compression (results shown in Appendix E). After compression testing the engine was started and run through the break-in cycle. Engine break-in consisted of running the engine at varying speeds with light to no-loads. During this run all systems were checked for proper functioning and the timing set.

The different test loads and speeds are detailed in the data found in Appendix F. These speed and loads were the same points used during the baseline test. The only noteworthy difference between the baseline test and this insulated housing test was that oil temperatures were increased to $101.7 \mathrm{C}$ (215 F) plus or minus a few degrees going into the engine.

Thirty hours into the endurance test a problem with the spark plug firing order was found. Due to a factory mislabeling of the distributor cap the leading and trailing spark plugs were firing in a backwards order. In other words the trailing plugs were firing first. This problem affected the performance of the engine and unfortunately had occurred throughout the baseline test as well. The wiring problem was corrected and 51 total hours of endurance testing was completed without further incident. 
After completion of the 51 hour test the engine was disassembled and inspected. Wear was detected on the rotor side seals and rotor oil seals which were rubbing against the thermal barrier coating. Similarly, the zirconia-coated intermediate housing experienced minor wear where it was rubbed by the seals. The intermediate housing, seen in figure 5.6.0-1 was still reusable despite the wear, and the coating itself were in excellent condition. No damage to other parts were found during post inspection. One of the most likely reasons for the excessive seal wear was the rough surface of the coating after lapping. The seals appeared to have lapped the coating because after testing the coating was smoother (down to 2 micro-inches from 20 micro-inches of roughness in some areas). At the time the coated intermediate housing was tested no candidate side seals had been procured.

As was already mentioned, an ignition problem was found part way through the coated intermediate housing test. In an effort to make fair comparisons to the baseline test all data comparisons are made under like-conditions. For example, the baseline test data are compared to only that first portion of the coated intermediate housing test data when the ignition was incorrect. The rest of the data taken during the test with the coated intermediate housing can only be compared with that data taken during the test with coated rotors and coated rotor housings (ignition correct in these cases).

Figures 5.6.0-2 through 5.6.0-5 show the dramatic decrease in the amount of heat transferring into the oil system while testing the insulated intermediate housing as compared to the baseline test. These figures represent the oil temperature out of the engine subtracted by the oil temperature into the engine. Other areas such as power output and fuel consumption were basically unchanged by using the insulated housing.

\subsubsection{Rotor}

The second thermal-barrier-coated component screening test was with 2 undensified zirconia-coated rotors. The coated rotors were installed in the engine via the same disassembly, inspection, and reassembly procedures used in previous builds. The same testing parameters were measured as in previous tests. Likewise, the same speeds, loads, ignition timing, break-in cycle, oil type and temperature, and coolant were used.

During the first part of the test the engine ran quite well; but, as the test time was lengthened, carbon deposits built up on the rotors and rotor housings. These deposits were observed through exhaust port inspection (by removing the exhaust header and visually looking inside the engine through the exhaust ports). Thirty-one hours into the test a major problem developed. While running a point at $5000 \mathrm{rpm}$ and $120 \mathrm{ft}-1 \mathrm{bs}$ of torque the rear rotor housing began to experience scuffing. The extent of the scuffing is shown in figure 5.6.1-1. Although the front rotor housing did not have this problem, it probably would have given more time.

The scuffing appeared to be caused from overheating the rotor housing plus oil deposit build up on the rotor housing. Fortunately, the engine was shut down before major damage occurred. Upon post-inspection, the only parts found unusable were the apex seals which had uneven wear. The rotor housings were cleaned up and the engine reassembled with new apex seals. The engine then completed 100 hours of endurance tests successfully. A photograph of the coated rotors is seen after testing seen in figure 5.6.1-2. It should be noted that after scuffing had occurred the fifth and sixth auxiliary intake ports 


$$
\text { of ous QuAY }
$$

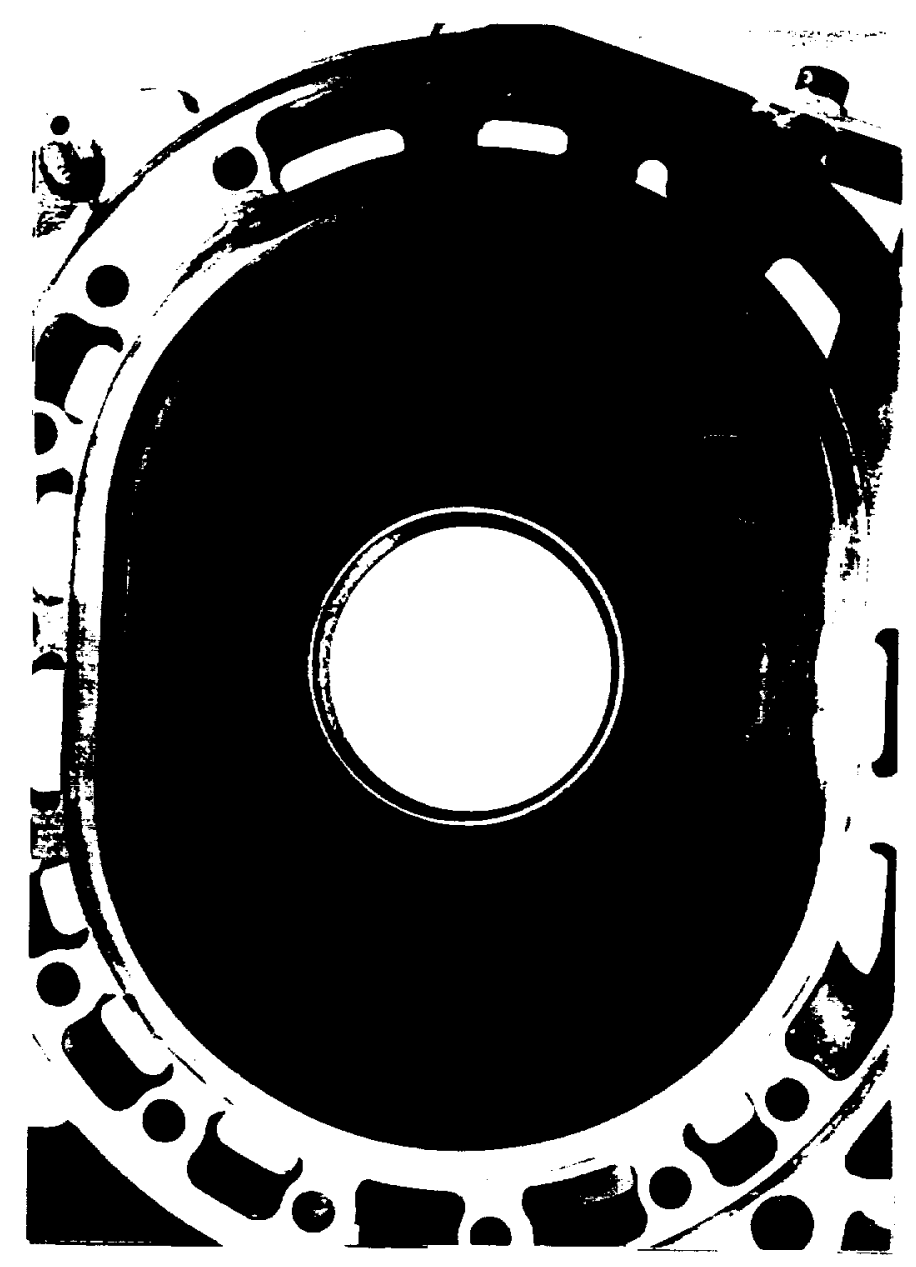

$$
A I-C / 122-4
$$

Figure 5.6.0-1. Zirconia coated Intermediate Housing Densified by Kaman Science's Process After Completing 51 Hours of Testing. 


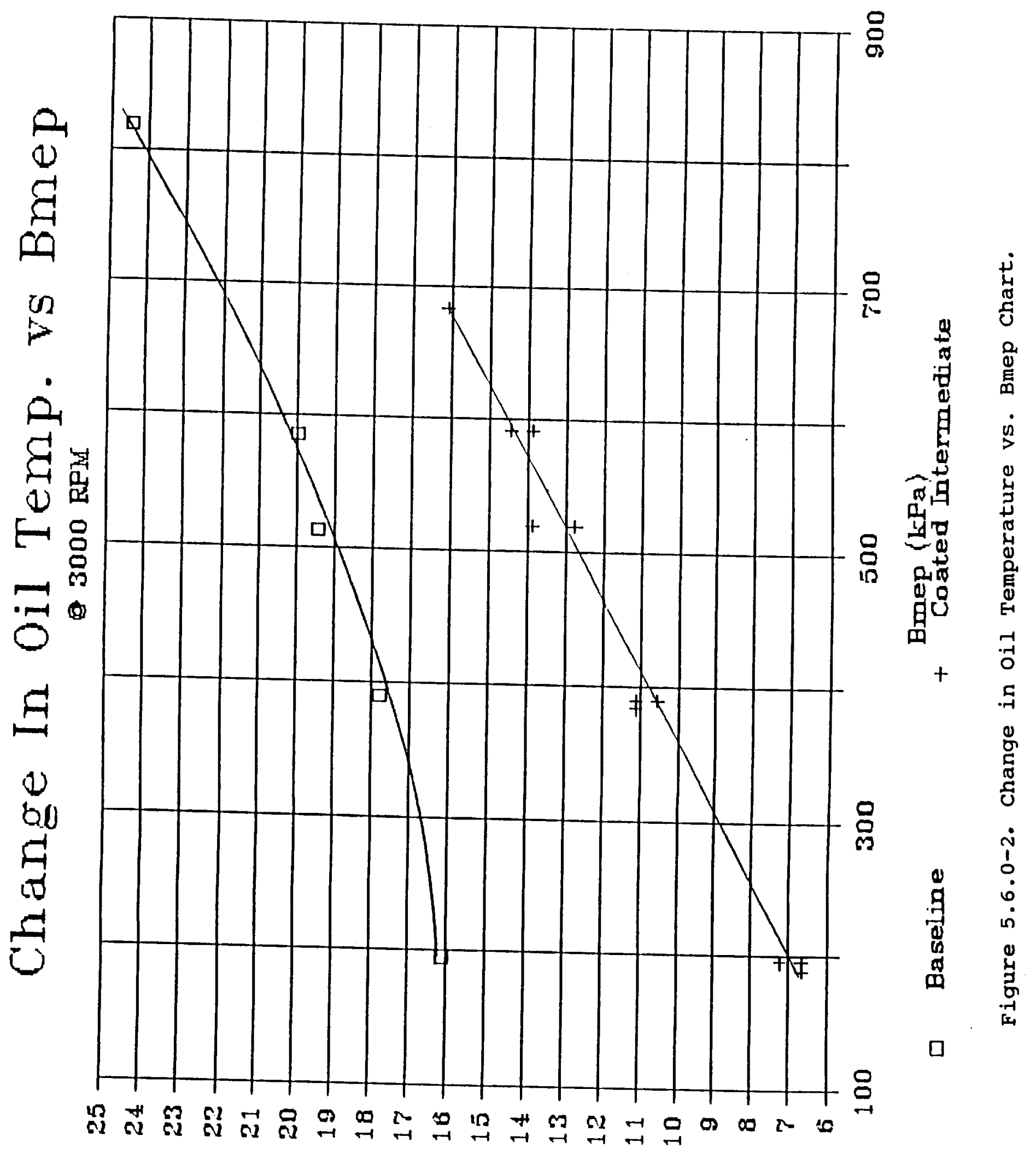

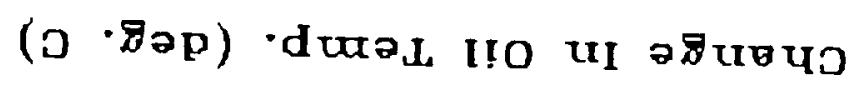




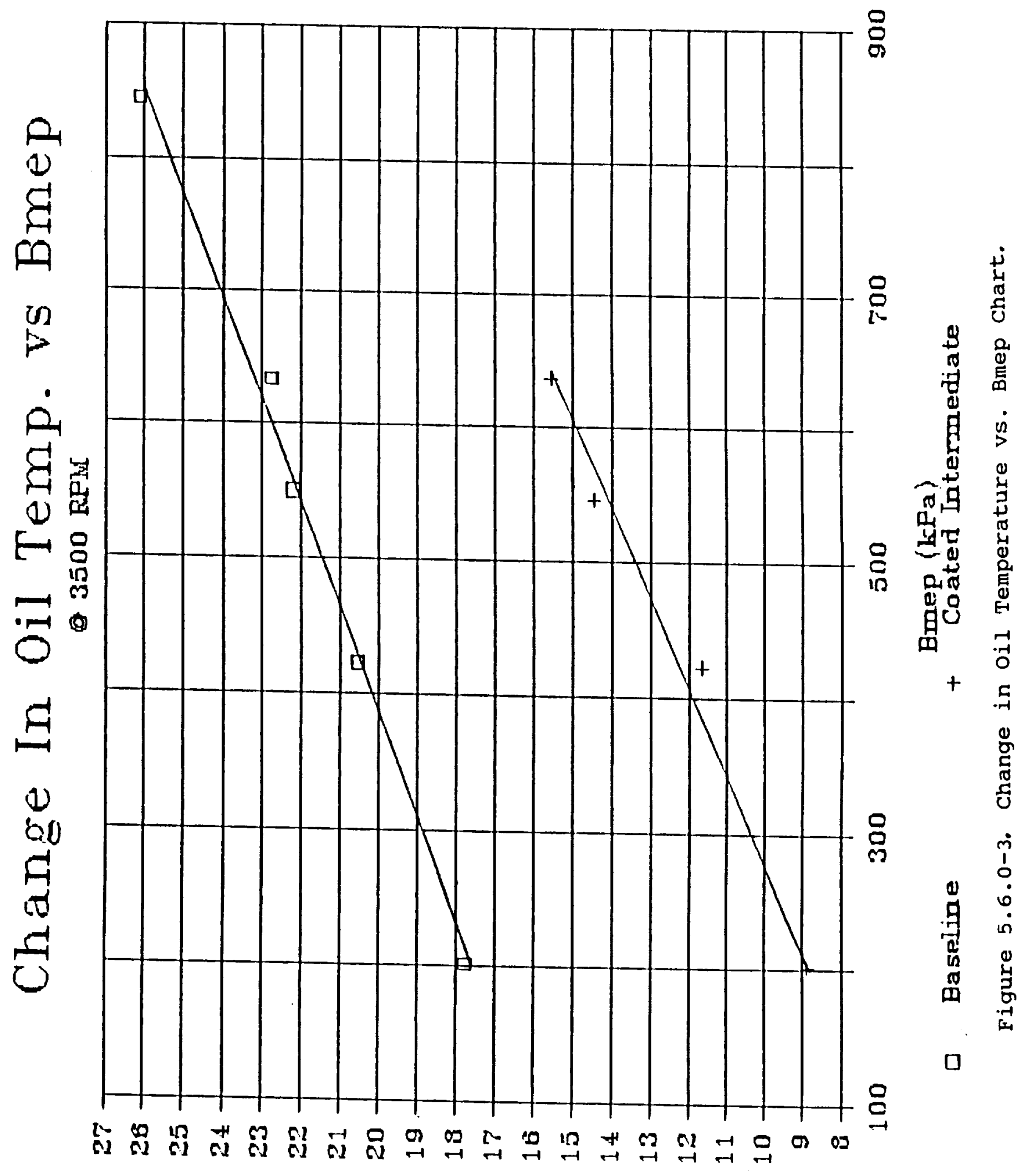

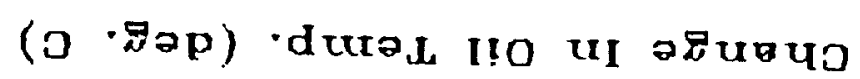




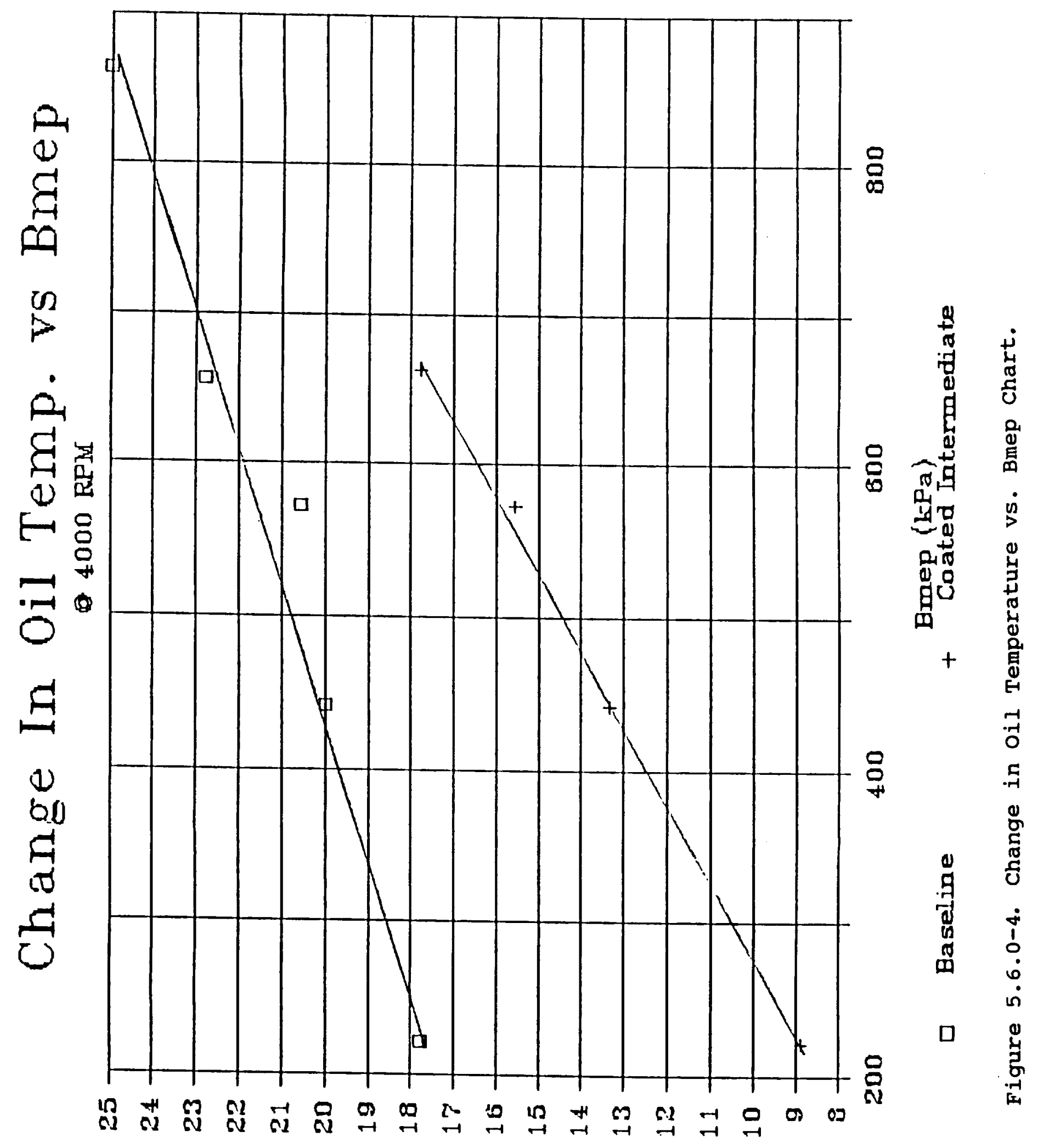

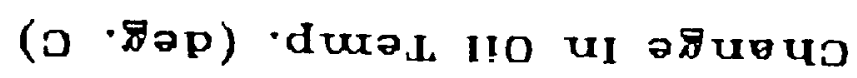




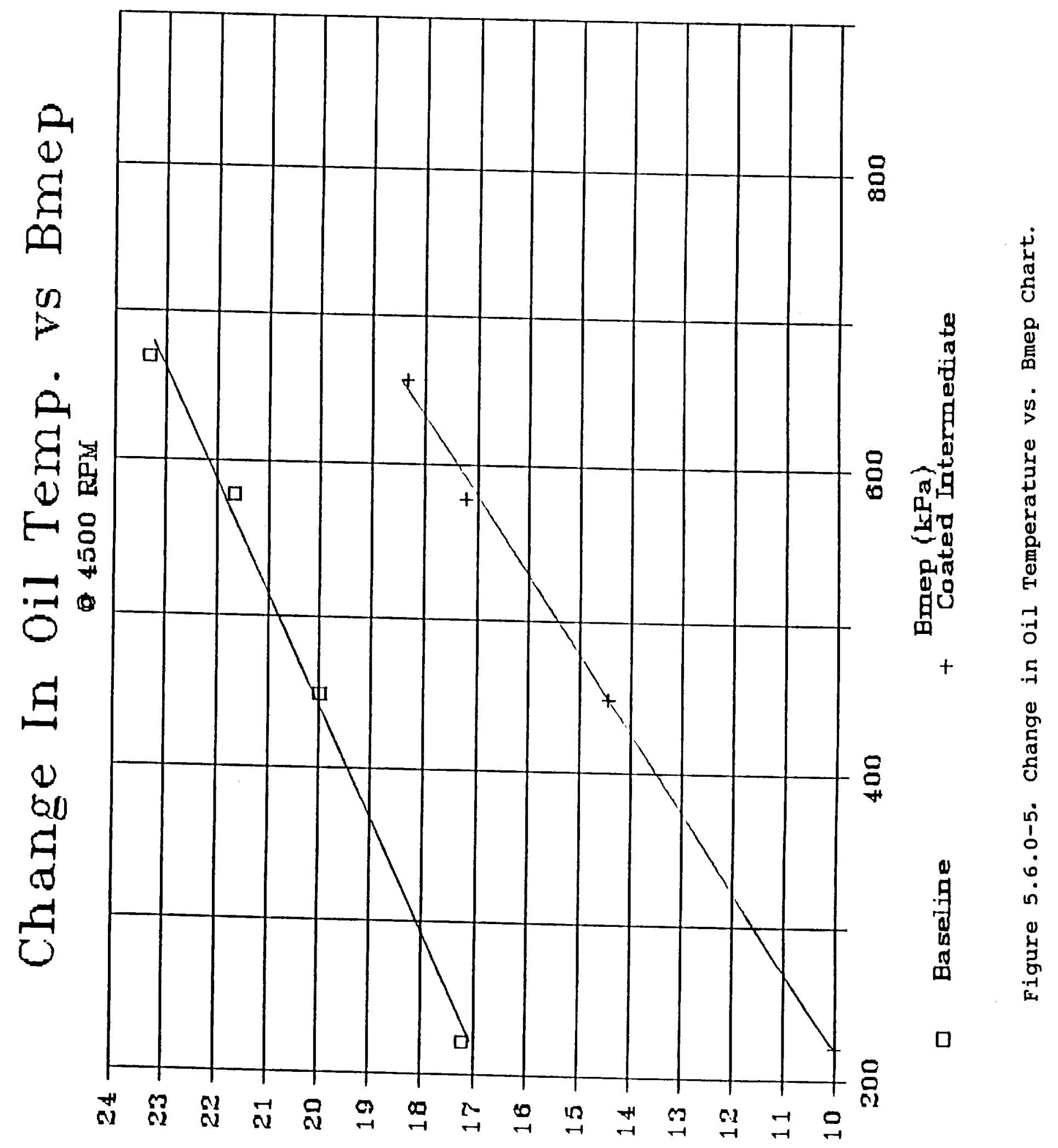

$(0 \cdot 8 ә p) \cdot$ dur⿰氵 


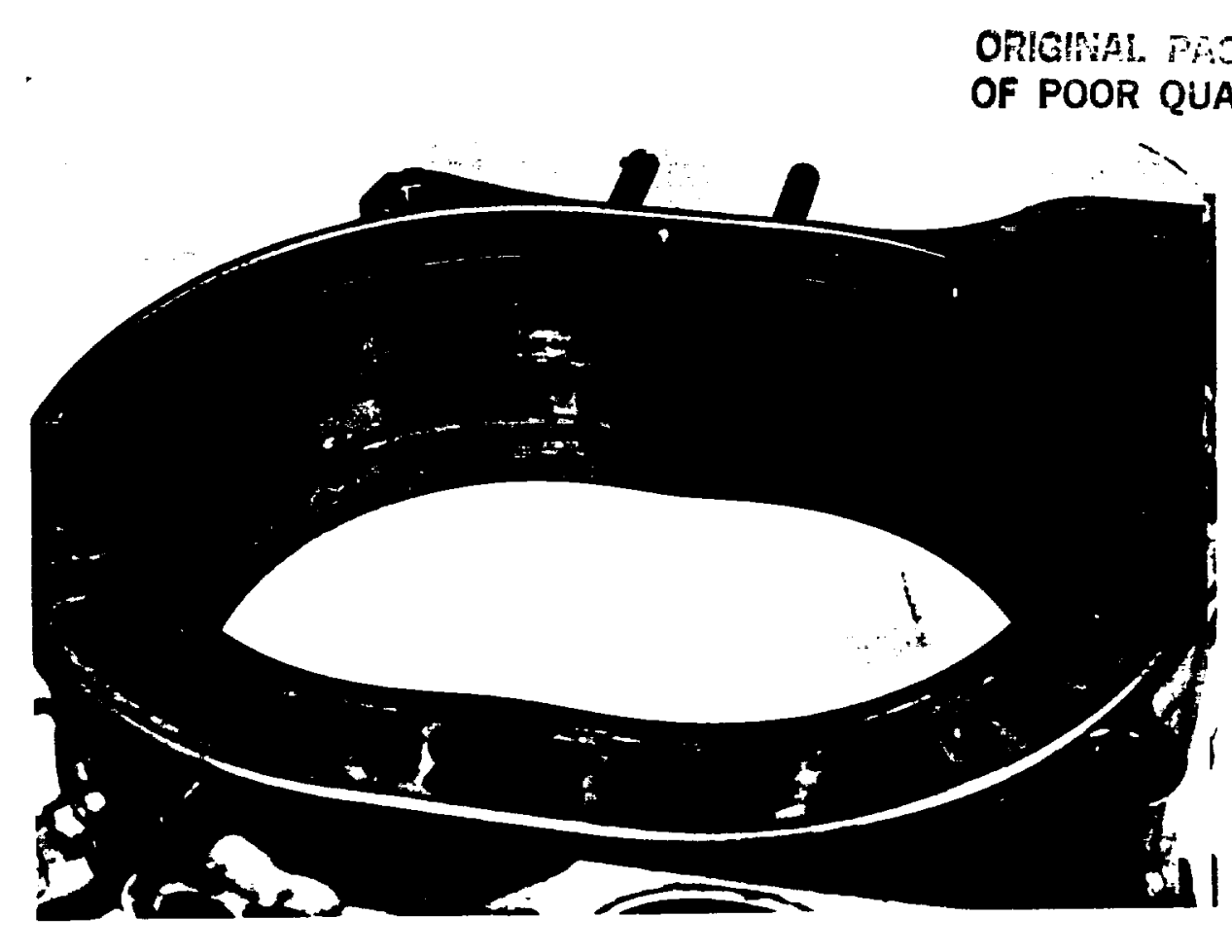

$A I-C / 126-4 A$

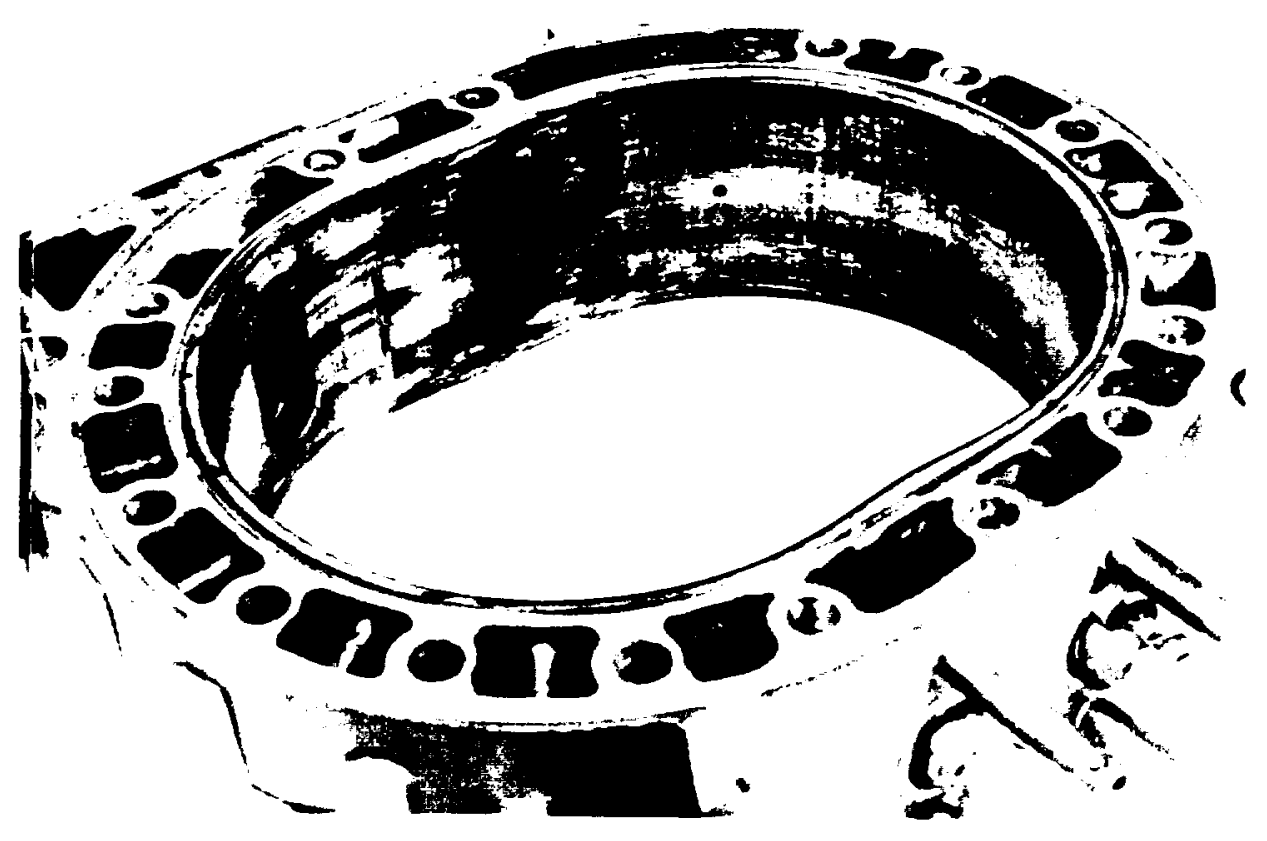

$A I-C / 126-3 A$

Figure 5.6.1-1. Rear Rotor Housing After 31 Hours of Testing Time with Thermal-Barrier-Coated Rotor. 


\section{ORIGINAL PACE IS}

\section{OF, POOR QUALITY}

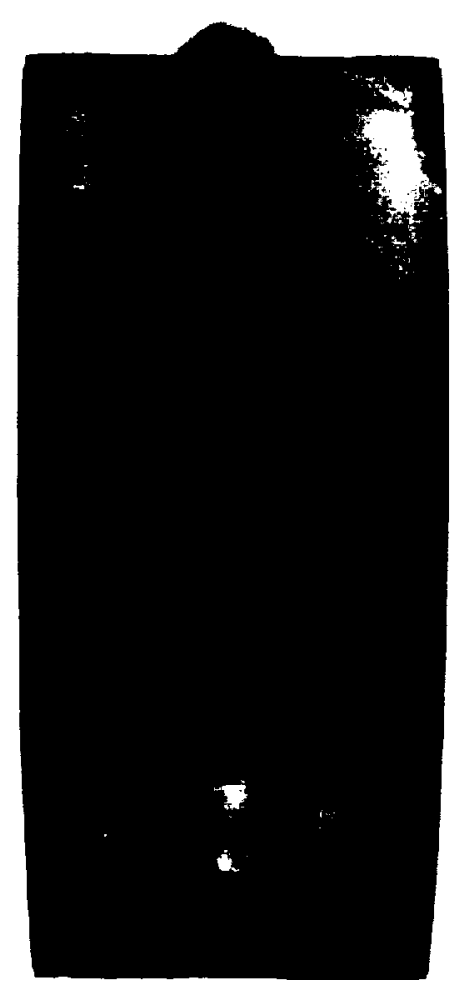

$B I-C Y 3-1$

Figure 5.6.1-2. Undensified zirconia Coated llazda Rotor A. ter 100 Hours of lesting. 
were manually opened in an effort to introduce a cool combustion charge later in the combustion cycle. These ports were left open for the remainder of the testing. By opening these 2 ports, both the fuel consumption and the power output did increase by a small amount. Data gathered from testing these undensified rotors is found in Appendix G-I.

There was a dramatic decrease in the amount of heat transferring into the oil system. Figures 5.6.1-3 through 5.6.1-7 show the data comparisons between the coated intermediate housing and the undensified coated rotors. Here, ignition timing was correct in both cases and though the 2 data plots are similar for every speed and load, both cases are much lower than that of the baseline test. The 2 coated rotors (combined in one assembly) are capable of reducing heat transfer into the oil system more than when using the one coated intermediate housing.

A second change in the data between the coated intermediate housing and the coated rotors was a dramatic increase in exhaust temperatures in the case of the coated rotors. Figures 5.6.1-8 through 5.6.1-12 show the comparison between the coated intermediate housing and the undensified coated rotors. Again, only data taken with correct ignition are compared.

One more candidate thermal-barrier-coated rotor was tested after completing the 100 hours of testing with the undensified zirconia-coated rotor. This test was with 1 zirconia-coated rotor densified by Adiabatics. This coated rotor was run in the engine along with 1 stock rotor. All conditions of the test were identical to the previous test including the open fifth and sixth intake ports. This test used stock seals and housings. This endurance test ran 100 hours without incident. A photograph in figure 5.6.1-13 show the rotor after testing. Everything passed inspection at the end of the test. It was noticed, however, more carbon deposits had developed in the rotor housing run with the stock rotor than in the rotor housing run with the coated rotor (seen in figure 5.6.1-14). The data gathered from the densified rotor test is found in Appendix G-II.

In both densified and undensified coated rotor durability tests the coating was in excellent condition after testing.

\subsubsection{Rotor Housing}

With the screening test successfully completed for thermal-barrier coated rotors and intermediate housing, testing proceeded to the rotor housings. The first rotor housing tested was the thermal-barrier coated stock aluminum rotor housing. As described in Task V, only 1 of 2 rotor housings survived the coating process. Therefore, this test consisted of only 1 coated rotor housing located in the front of the engine. High temperature apex seals made from M2 tool steel were used in the rotor placed in the coated rotor housing. The rest of the engine was built using stock components. The engine was built and tested in the same manner as in the previous tests including using the same high-temperature lubricant SDL-1.

During the break-in cycle the engine ran well. Visual inspection through the exhaust ports showed that the coating was holding up. As more testing time elapsed it was noticed that blow-by was creeping up to $12.7 \mathrm{~mm}$ (one half inch) of water whenever loads and or speeds were being changed. As the engine remained at a new load and or speed, blow-by would slowly go back to zero. Several low speed and low torque data points were run, but after 14.7 hours of 


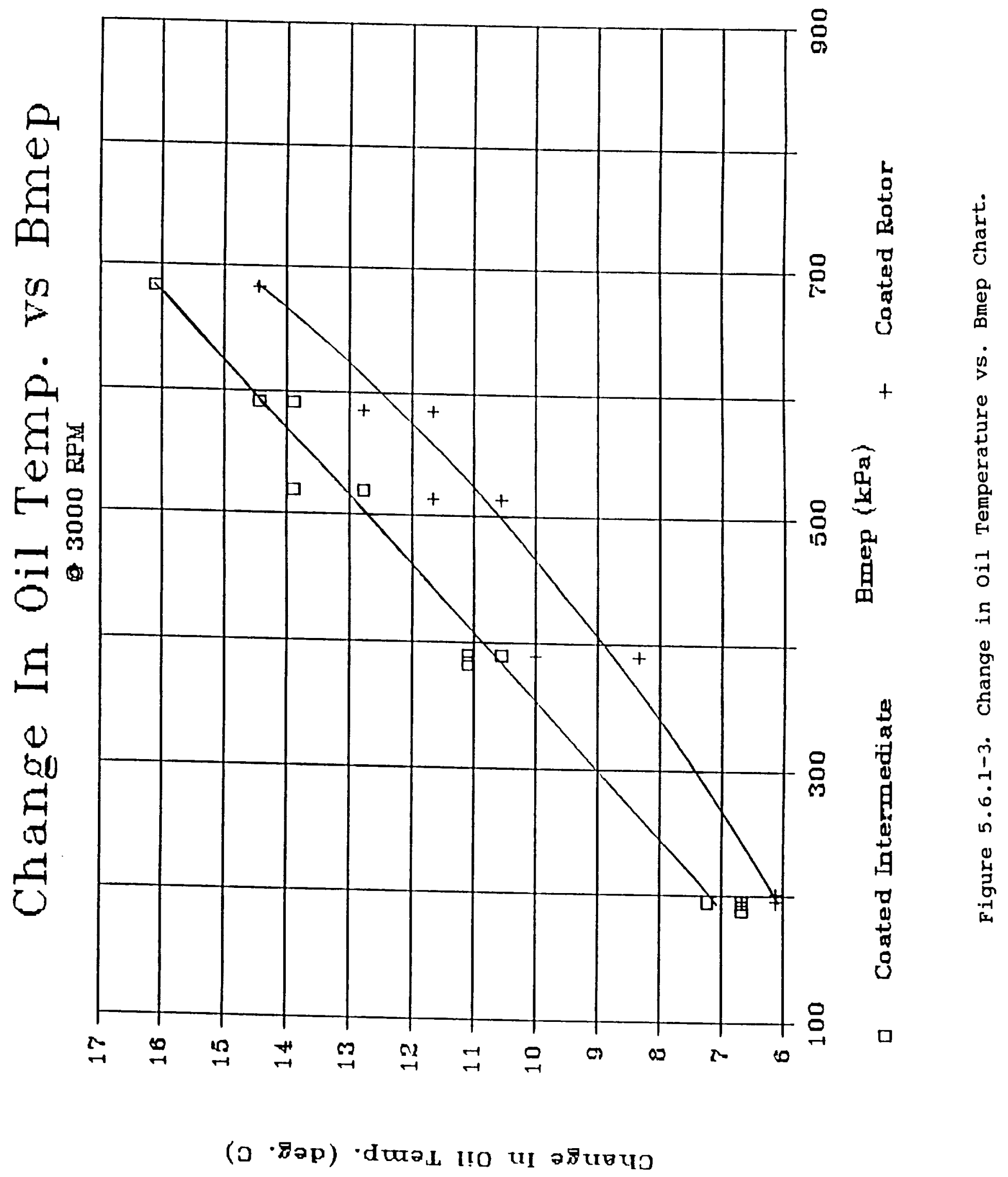




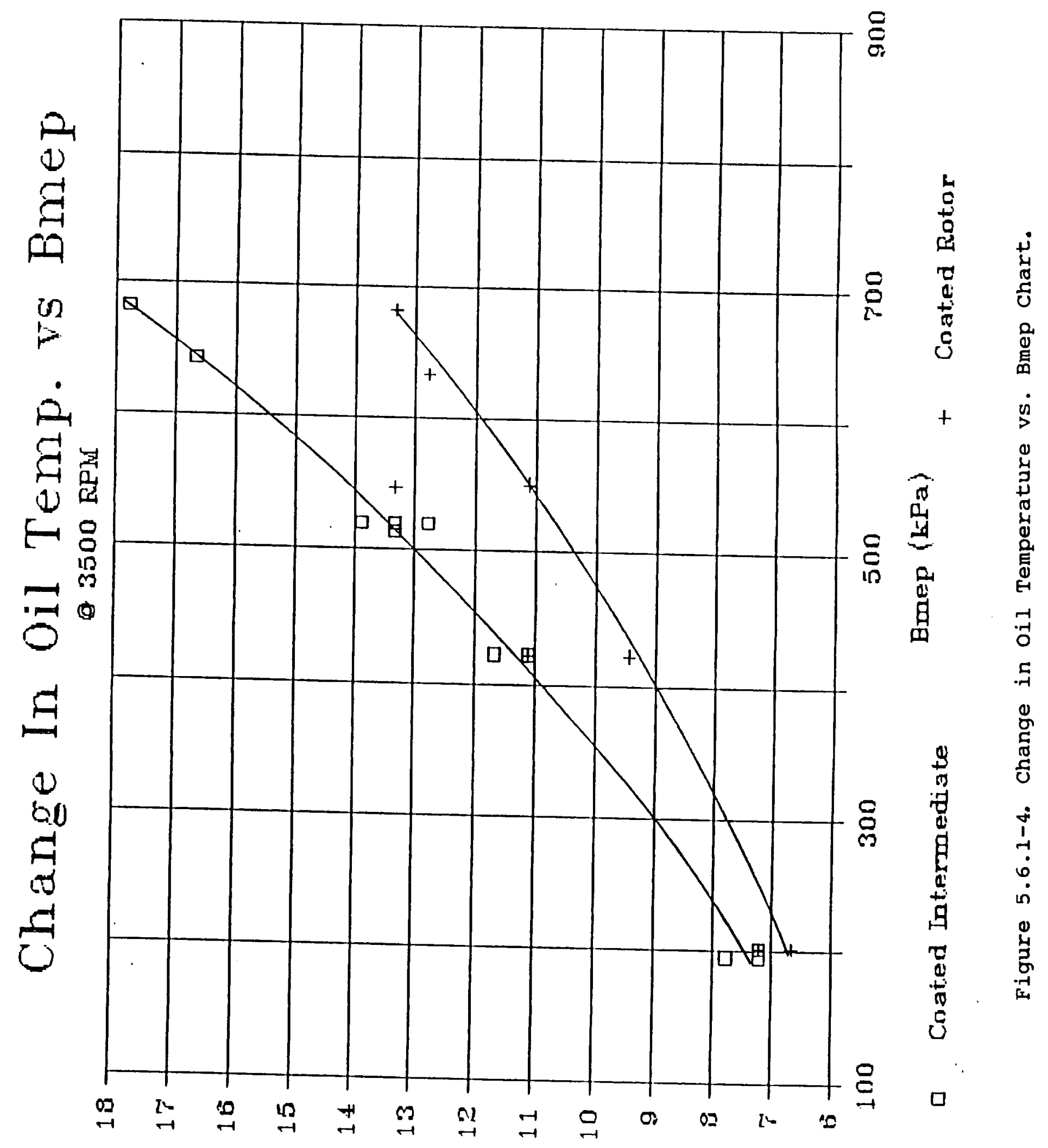

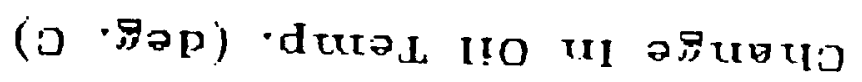




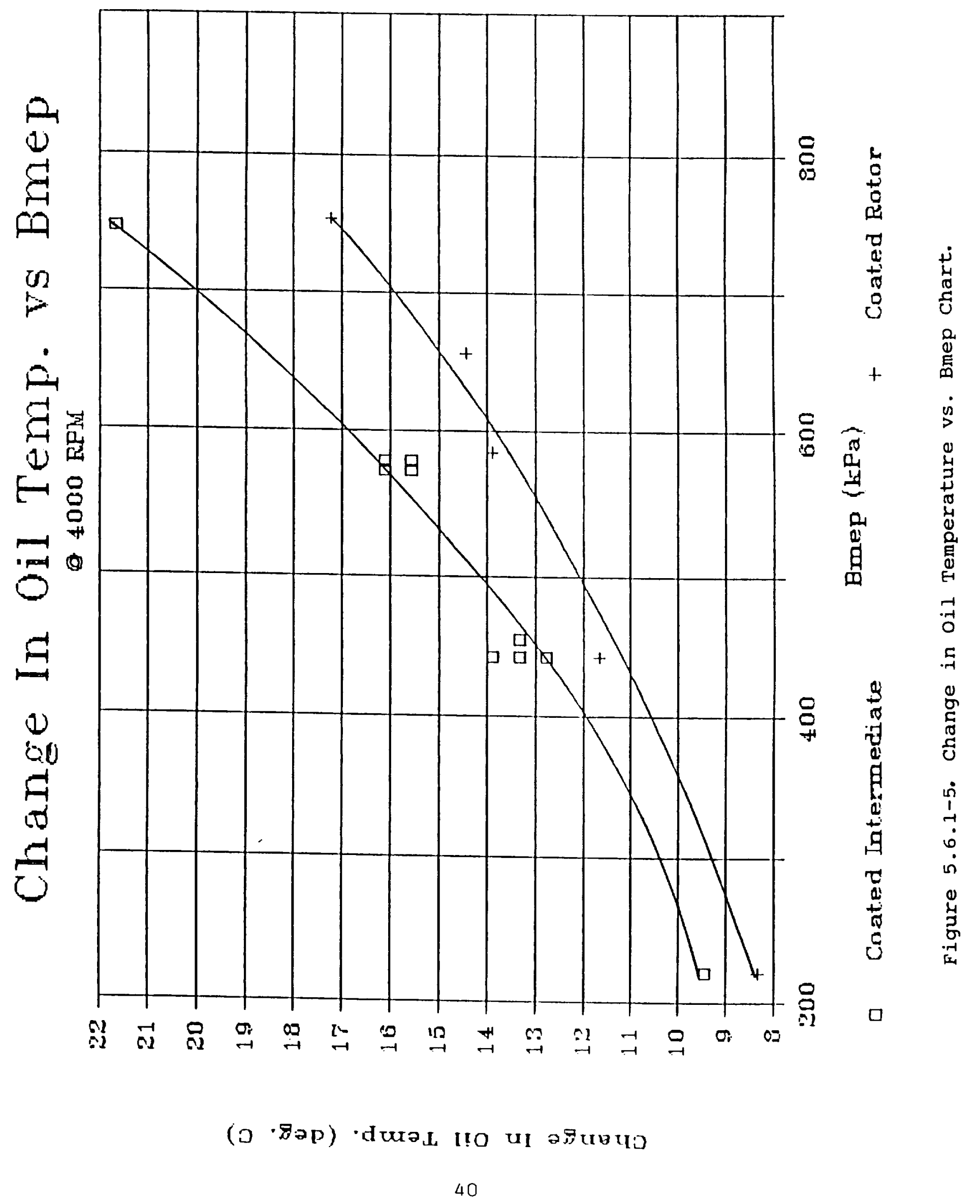




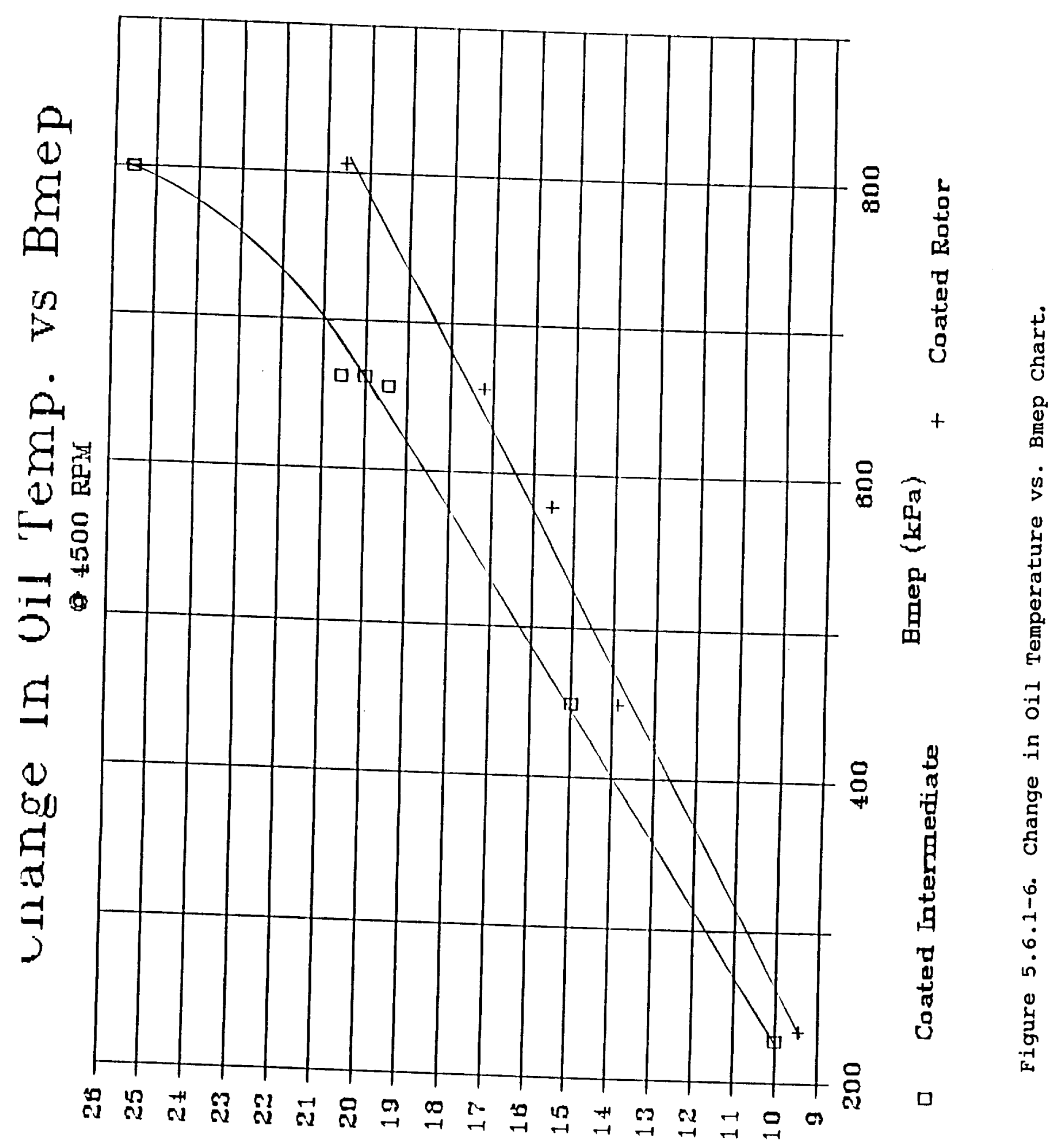

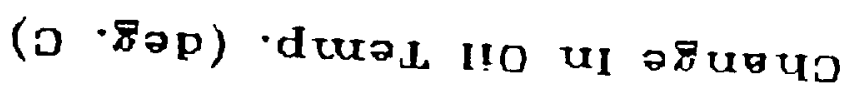
of pros dither 


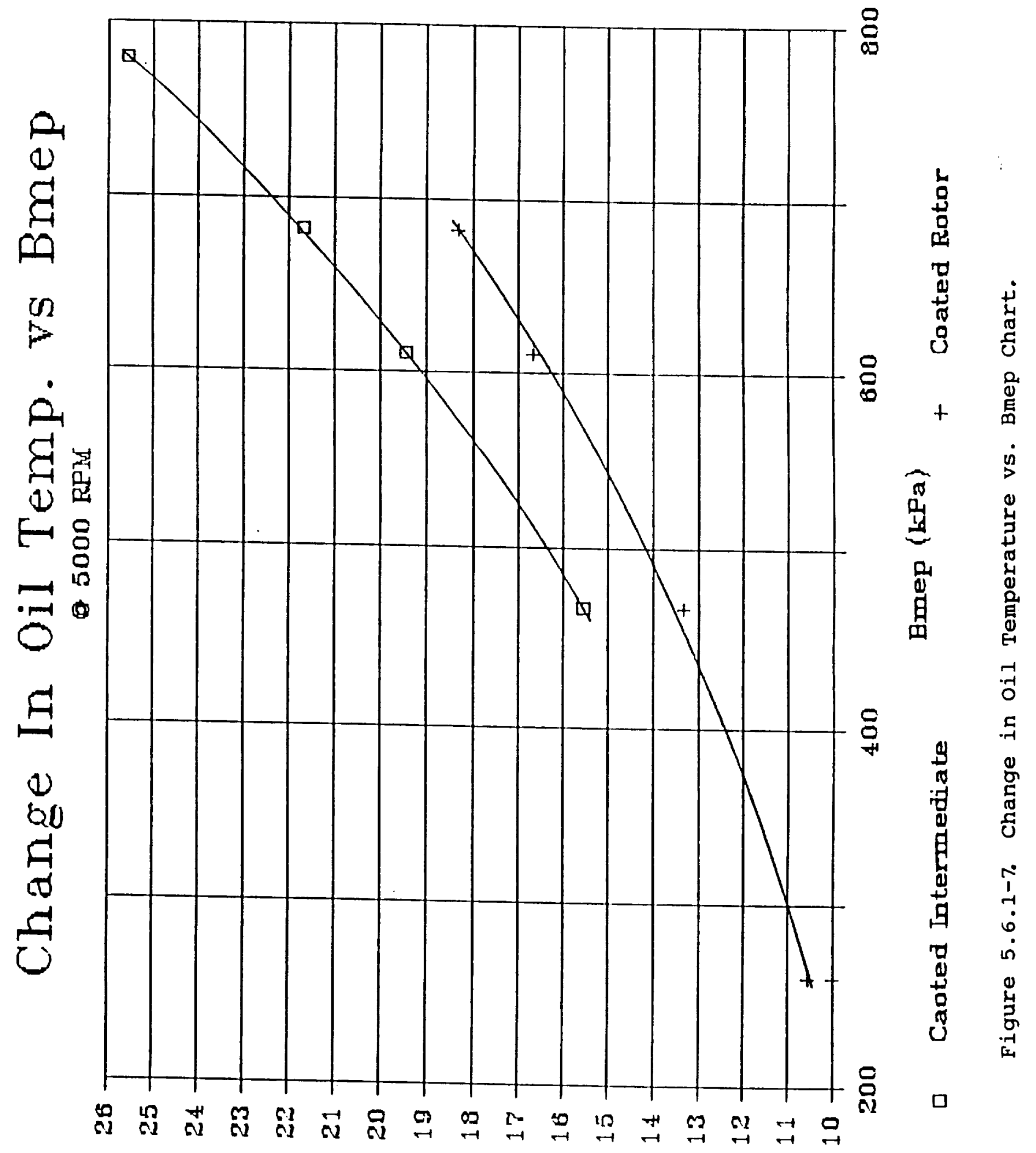

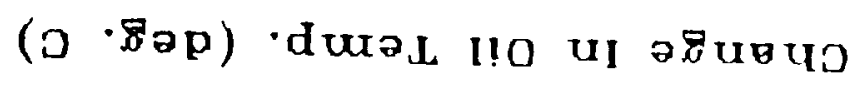




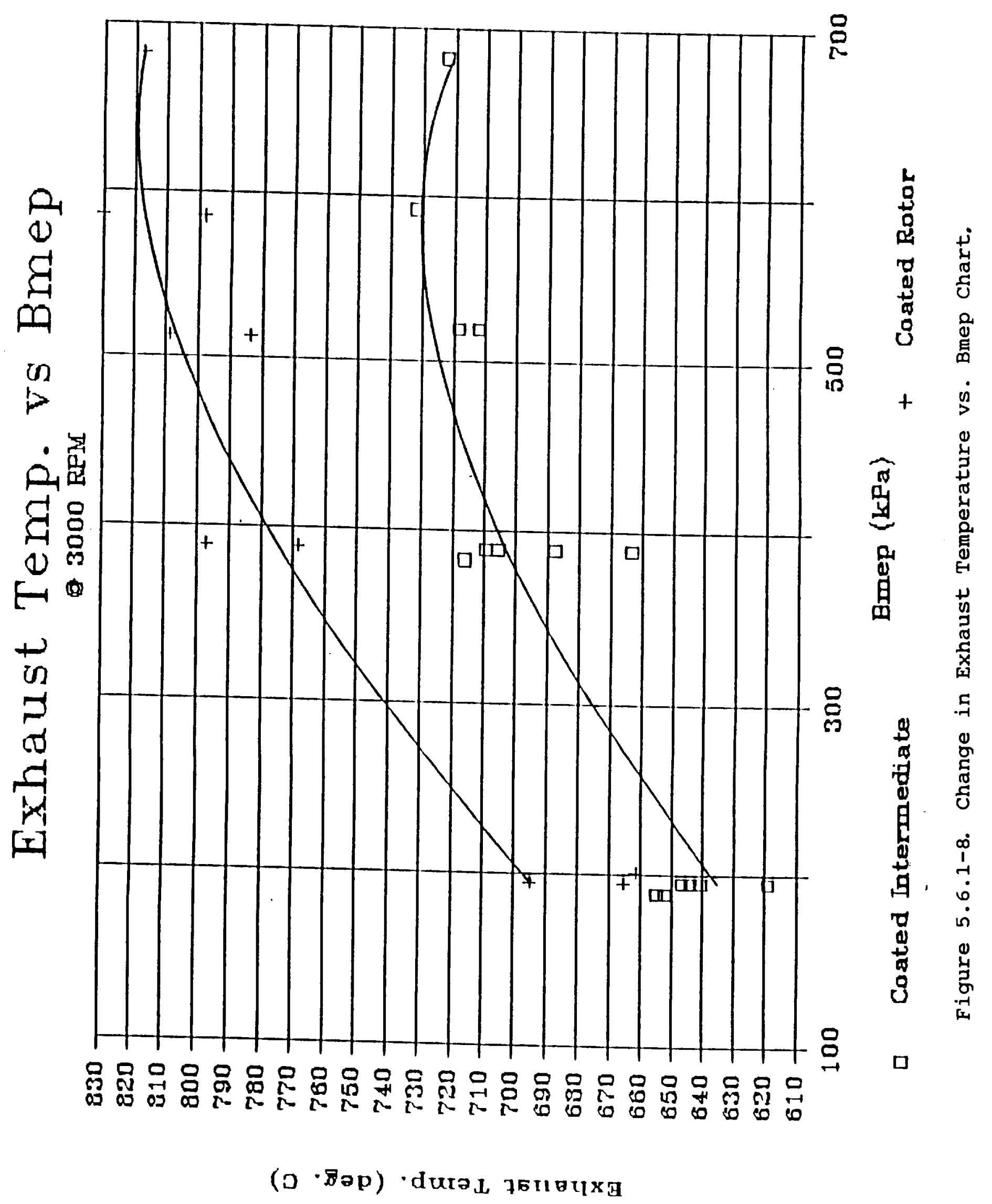




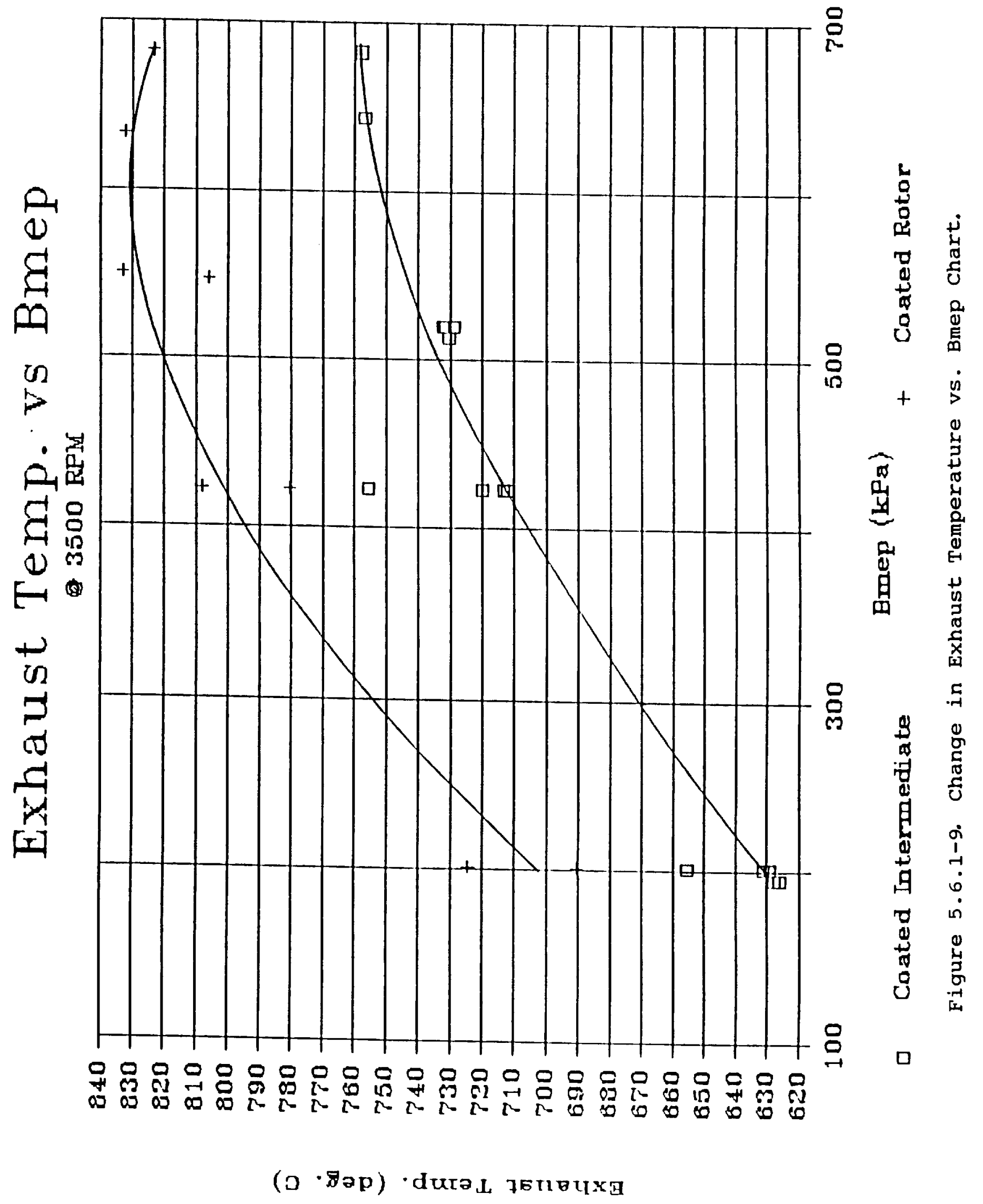




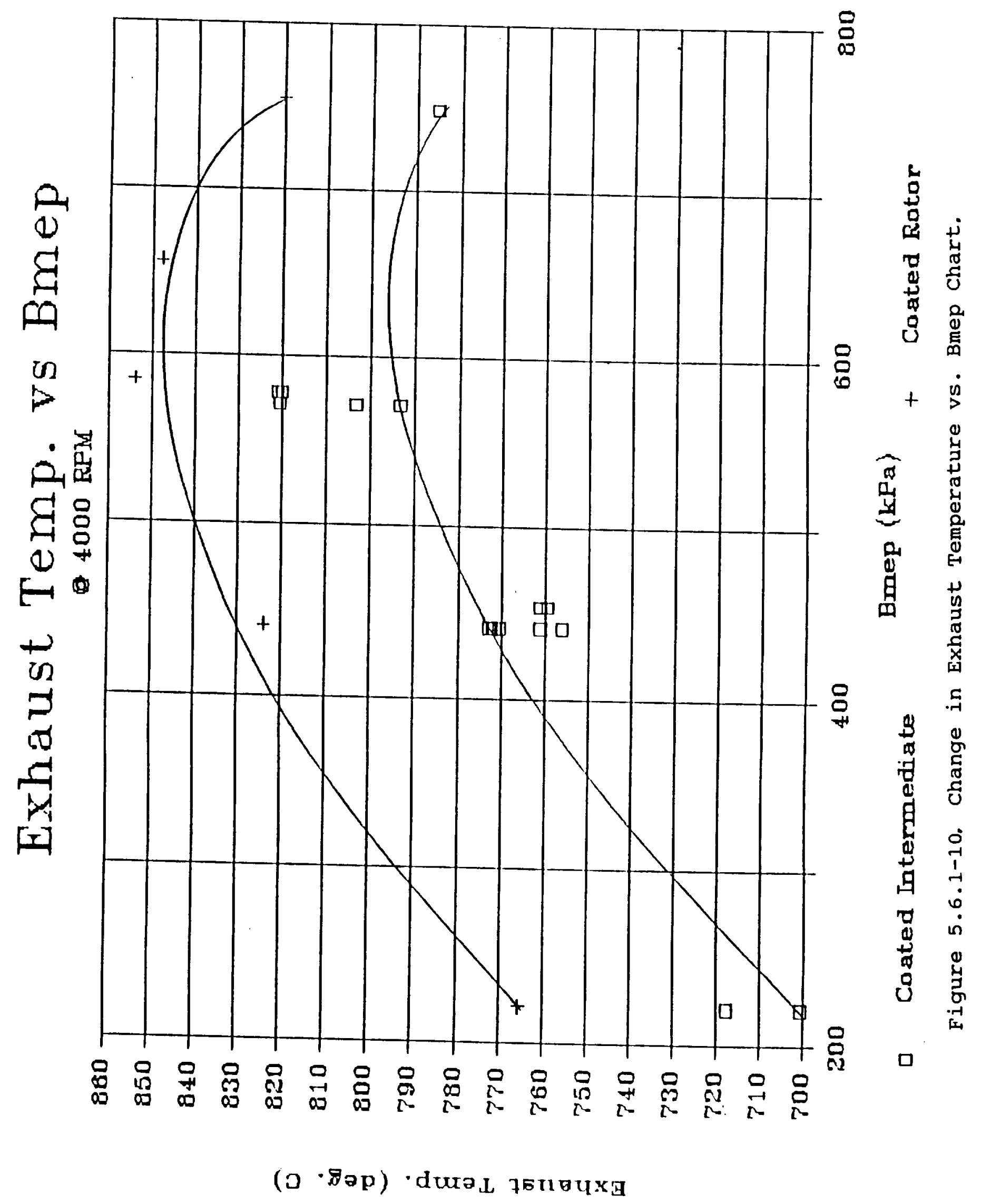




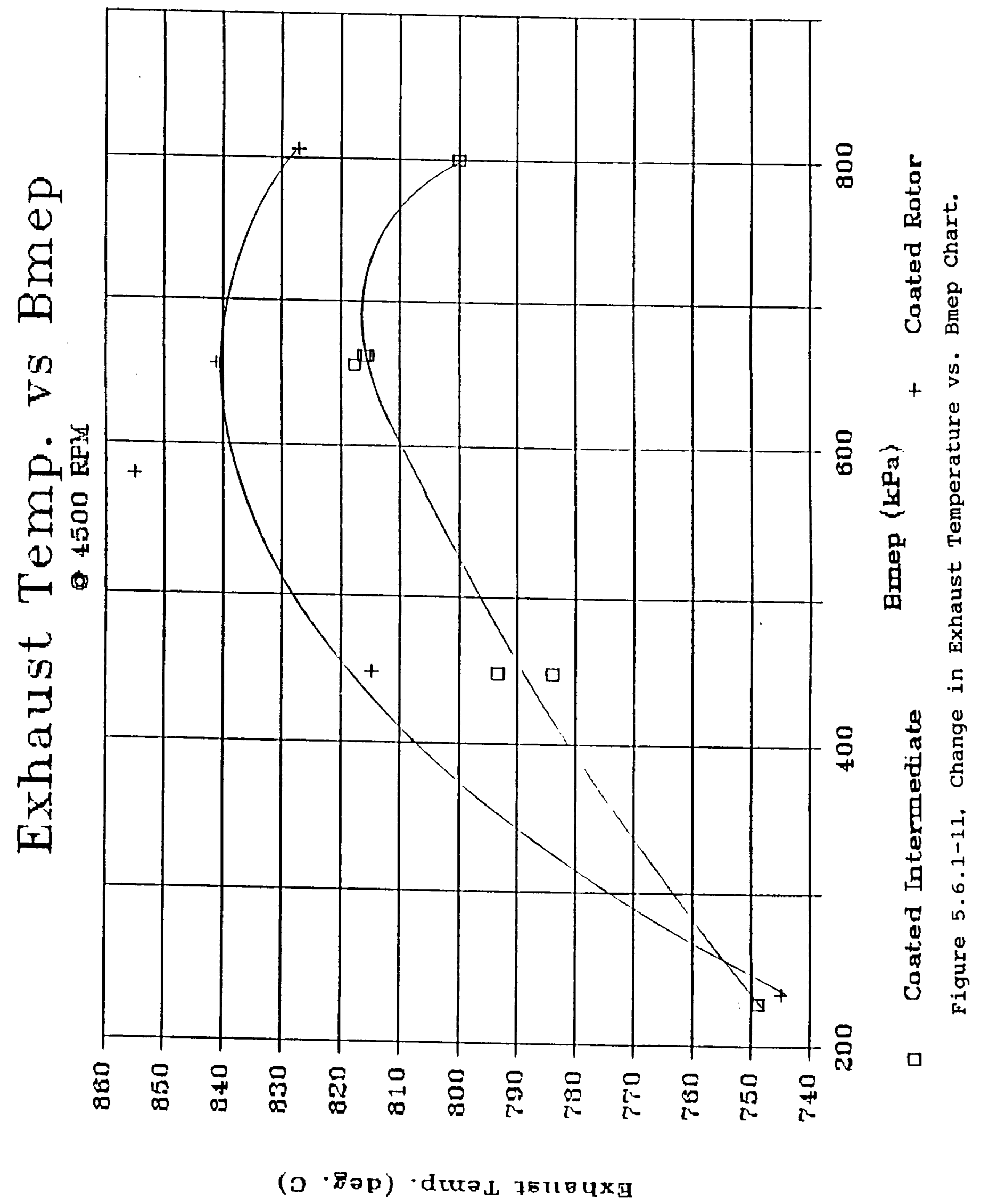




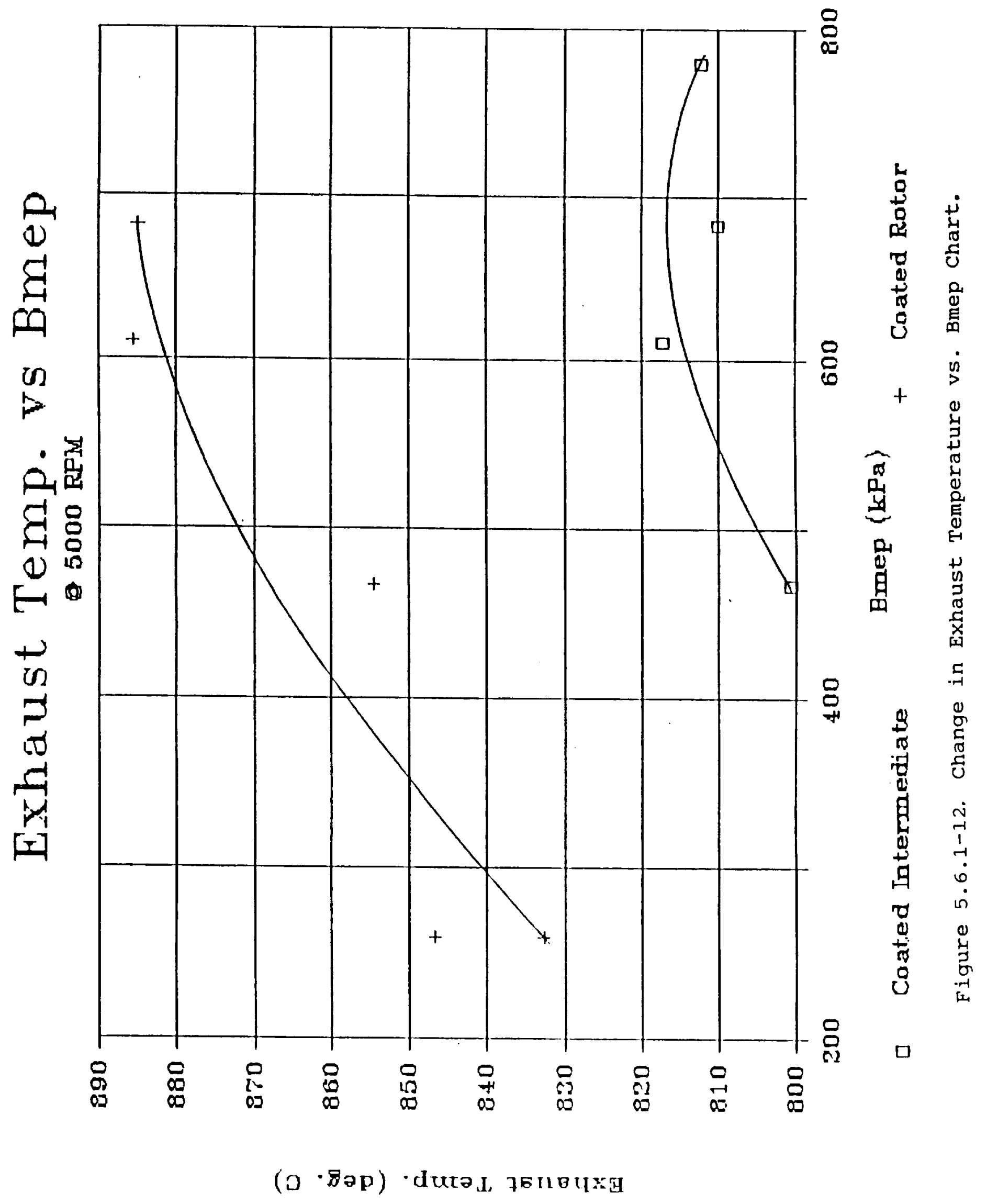


ORIENHS PDEE IS

OF POOR QUUALITY

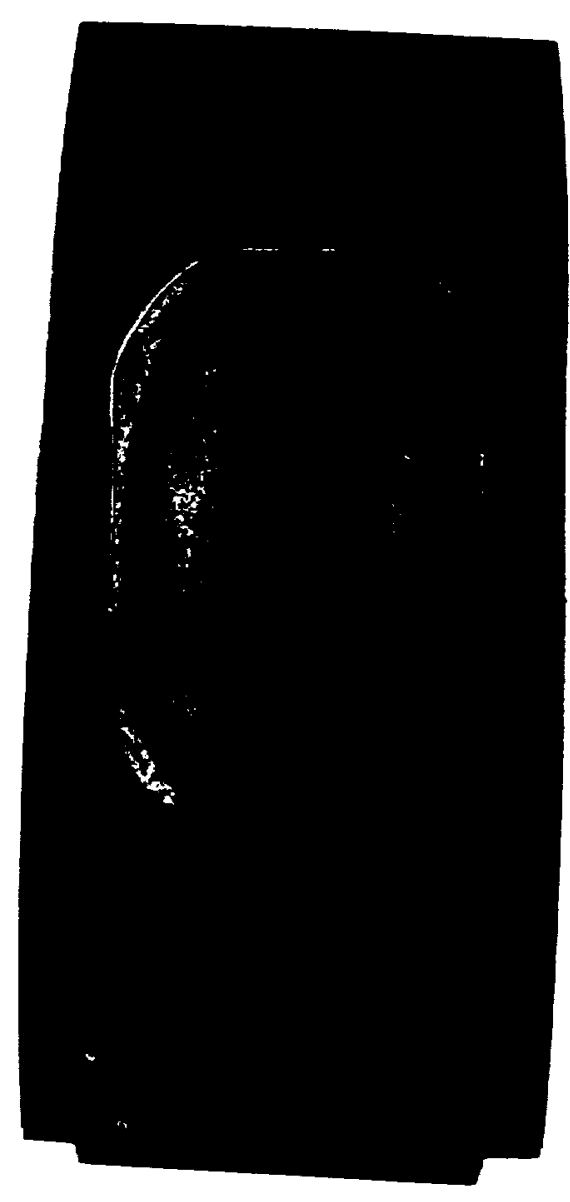

$A I-C / 13>-22 E$

Figure $5.6 .1-13$. Densified Zirconia Coated Mazda Rotor After 100 Hours of lesting. 


\section{ORIGISA PAG BS
OF POOR QUALMY}

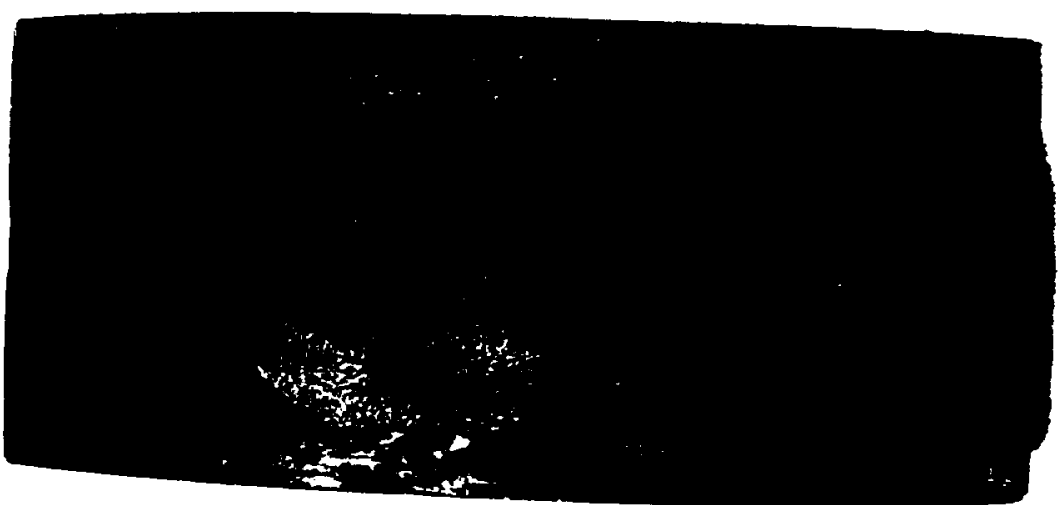

AI-C/137-19A

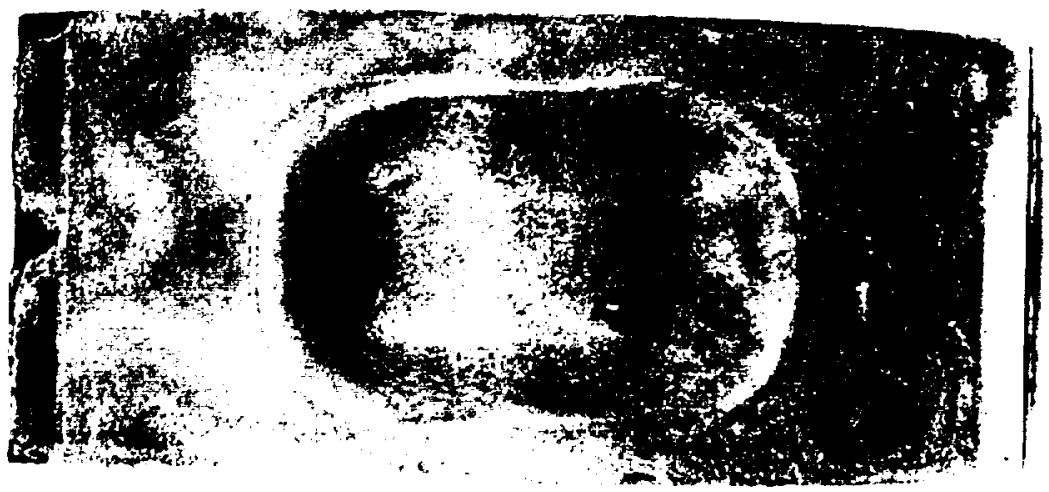

$A I-C / 137-15 A$

Figure 5.6.1-14. Stock Mazda Rotor (a) Compared with Densified coated liazda Rotor After 100 Hours Testing Together in one Build. 
engine testing visual inspection through the exhaust ports revealed coating failure. Data gathered from the housing test is found in Appendix $H$. Photos of the failed rotor housing are shown in figure 5.6.2-1.

When the coated stock aluminum rotor housings failed the apex seals which were made form M2 tool steel were also destroyed.

A request was then made by Adiabatics to NASA for an additional one month extension for testing coated cast iron rotor housings. This request was granted at a meeting at NASA LeRC with the Project Manager on June 17, 1988. This one month extension was later increased one additional month.

The screening test of the cast iron rotor housings consisted of an engine configuration with 2 thermal-barrier-coated cast iron rotor housing (detailed in Task $\mathrm{V}$ ). The front rotor housing had a stock rotor and stock apex seals plus 3 candidate side seals coated with Chem 2 (details in Task IV) which were placed against a stock intermediate housing. The rear rotor housing had a stock rotor and apex seals made of M2 tool steel plus 3 candidate side seals coated by Adiabatics (detailed in Task IV) which were placed against the stock intermediate housing. The engine was assembled and tested in the same manner as in all the previous tests.

As soon as the engine was started, blow-by was noticed. The engine was given a lengthy slow break-in but blow-by never returned to zero. Visual inspections through the exhaust ports showed the coating on the rotor housings to be in excellent condition After the break-in cycle the first 2 data points at 3000 rpm were run. At this point blow-by reached 3 inches of water and the engine was shut down.

The engine was removed from the test cell, disassembled, and inspected. The coating on both front and rear rotor housing was in excellent condition (see figure 5.6.2-2). Likewise, the side seals coated by Adiabatics and the apex seals made from M2 tool steel were in excellent condition. However, the Chem 2 coating on all 3 side seals located in the front rotor housing had worn off. Also, after 16.75 hours into tests the stock apex seals in the front rotor housing had become stuck. These were the only 2 major problems found. The rest of the engine passed inspection.

Since the coating on the rotor housings was still in good condition, further testing was performed. The engine was reassembled using the 2 coated cast iron rotor housings with a complete set of new apex seals made from M2 tool steel. The apex seals had not stuck previously. The same side seals were placed back in the engine. At this point a lubricant change was made to 10 W40 AMS-oil instead of SDL-1. The engine was assembled and tested in the same manner as before.

This build ran over 9 hours before the engine had to be disassembled again. During this run blow-by remained zero and the engine ran quite well. Then, when trying to run a point at $3500 \mathrm{rpm}$ a problem developed. A safety device malfunctioned shutting the engine ignition off. This problem was quickly corrected but the engine would not restart. A compression test on each rotor housing showed the compression to be essentially zero. Upon post-disassembly the reason for low compression was found. The seals which were made from M2 tool steel had warped (figure 5.6.2-3). The warpage occurred along the edge of the apex seal which contacts the trochoid contour of the rotor housing. 


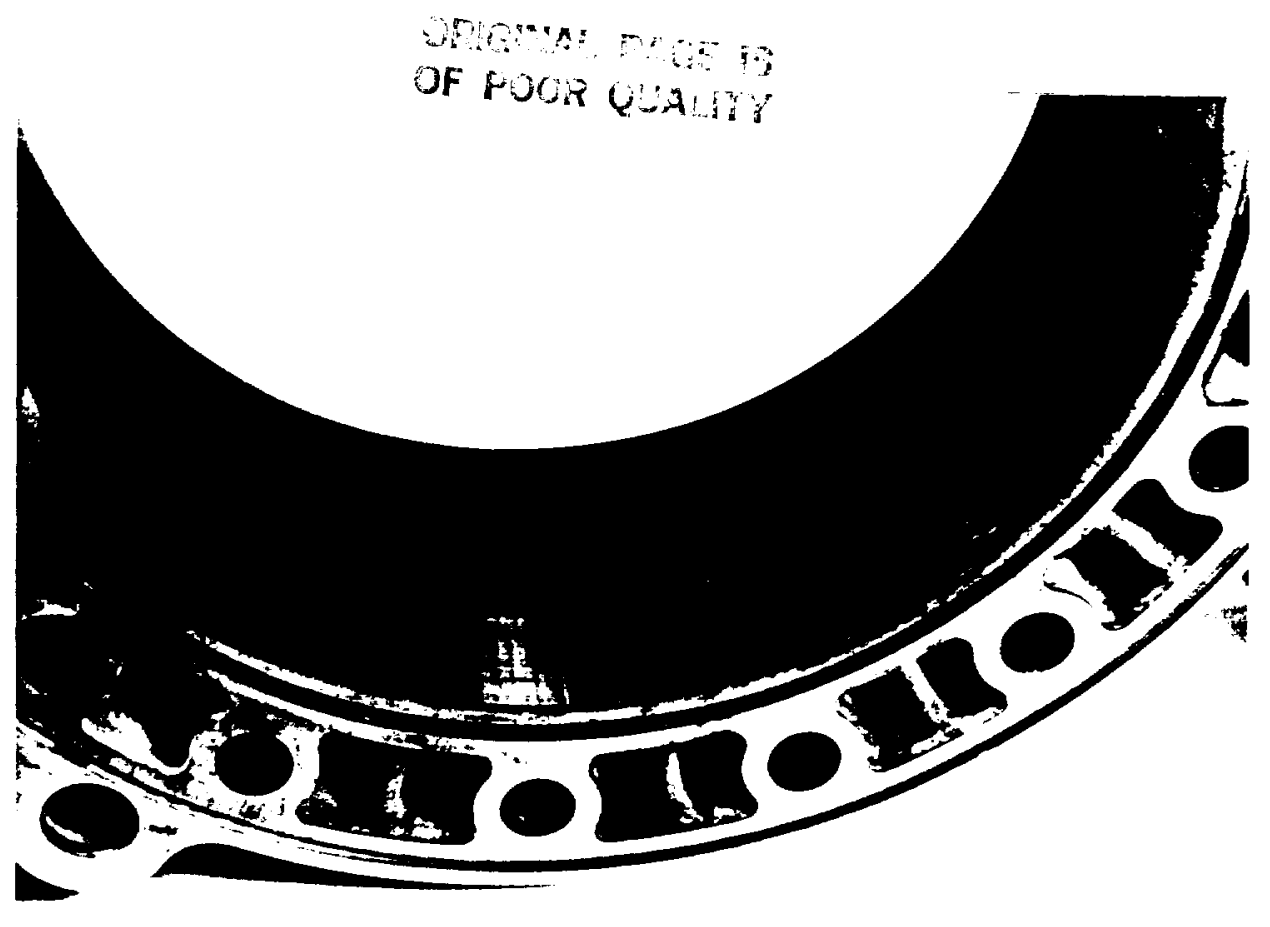

$\mathrm{AI}-\mathrm{C} / 137-14$

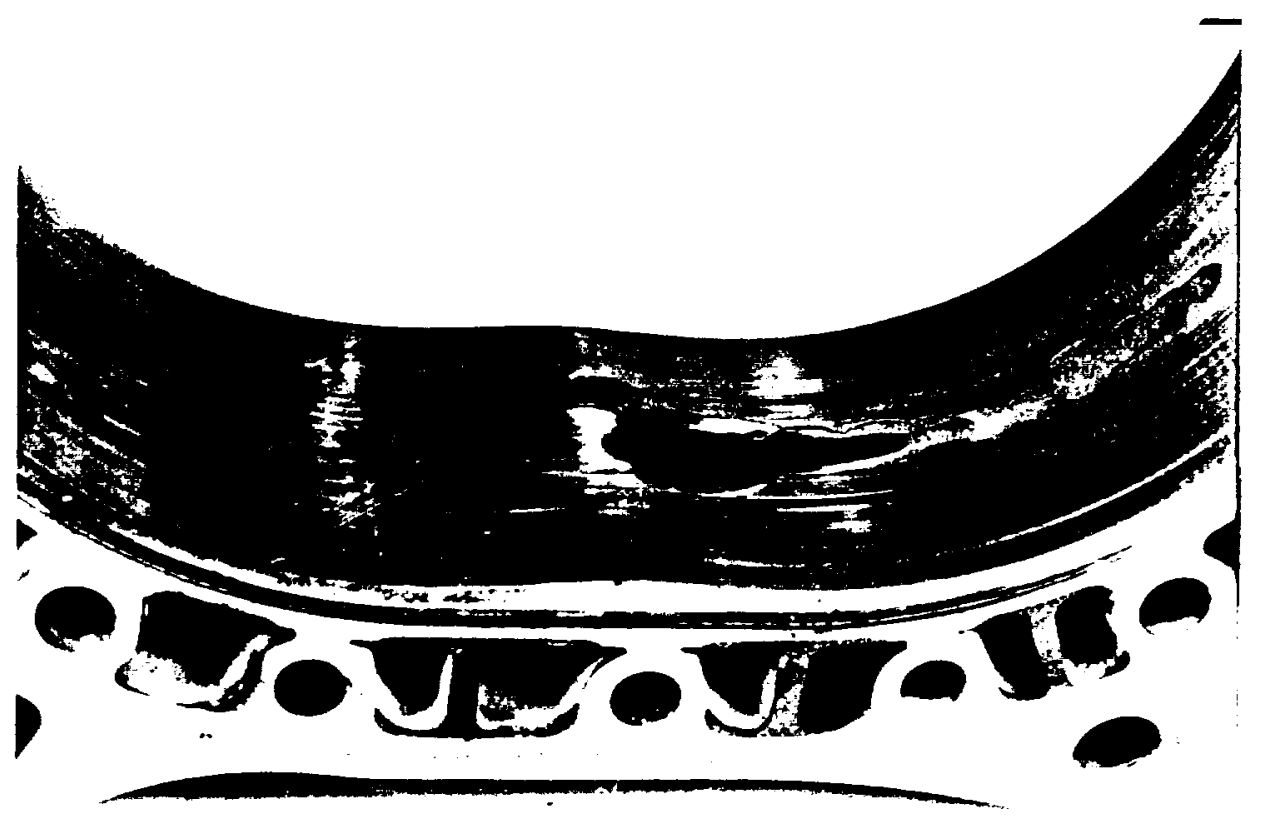

$A I-C / 145-15$

Figure 5.6.2-1. Failed Thermal Barrier Coating on Mazda Rotor Housing After 14 Hours of Testing. 
ORIGINAL PRAE IS

OF POOR QUALITY

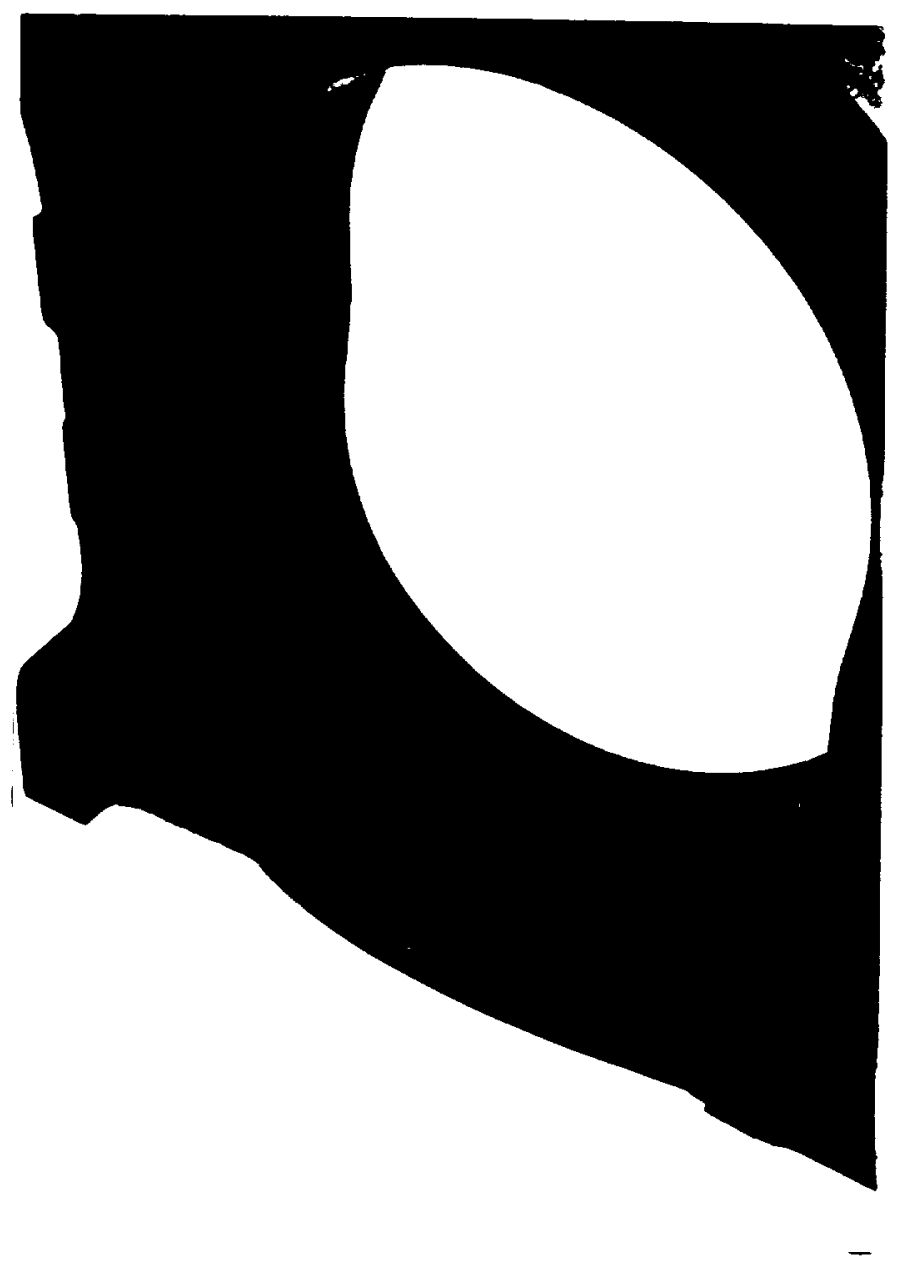

$A I-C / 150-22 A$

$\begin{array}{ll}\text { Figure 5.6.2-2. } & \text { Coated Cast Iron Rotor Housing After Testing } \\ & 16.75 \text { Hours. }\end{array}$ 
ORIGINA PMSE IS

OF, POOR QUALITY

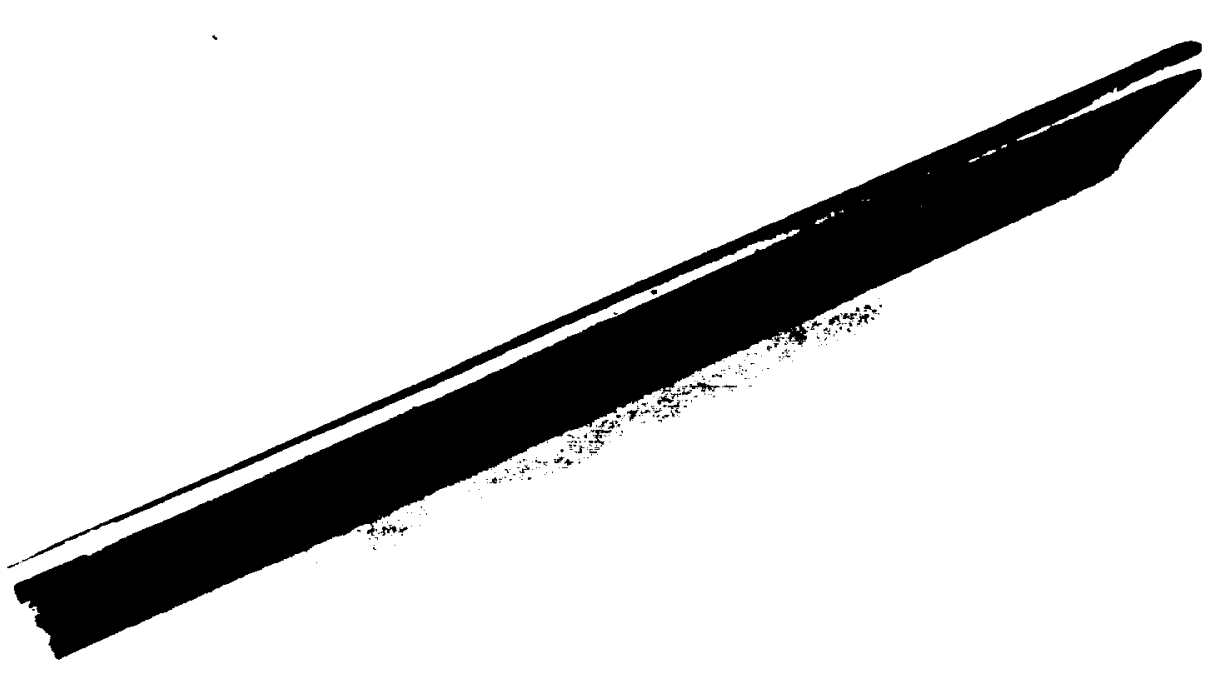

$A I-C / 150-25 A$

Figure 5.6.2-3. Warped M2 Tool steel Apex Seals Tested with coated cast Iron Rotor Housing. 
At this point the coating on the rotor housings was still in good condition so the engine was reassembled for further testing. This build consisted of all the previous components with the exception of the warped M2 apex seals which were replaced with stock apex seals. It was hoped that the change in lubricant to AMS-oil would be sufficient to keep the apex seals from sticking. Other components like the side seals which were coated by Adiabatics, Inc. and the coated cast iron rotor housings were in good condition and therefore placed back in the engine in their original locations.

The engine was reassembled and tested in the same manner as in the previous tests. Again, while the engine was running a point at $3500 \mathrm{rpm}$ the compression was lost. The engine was disassembled and warped apex seals were again found (5.6.2-4). Unfortunately, the coating on the rotor housings was also found to be in bad condition. Small areas of coating had chipped at various areas around the trochoid contour. In 1 area of the compression zones of the front rotor housing the coating had separated from the parent material at the bond coat. Between the problem with the apex seals and the coating failure on the rotor housings, the testing was stopped at this point. The total testing time for the cast iron rotor housings was 32.5 hours and the final condition of the rotor housings can be seen in figure 5.6.2-5. A comparison between a stock side seal and one of the slurry coated side seals (after testing) is shown in figure 5.6.2-6. The data gathered from the testing of the cast iron rotor housings is found in appendix I.

During the testing with coated cast iron rotor housings, housing temperatures were observed as being twice as high as was observed during other testing.

Table 3 summarizes the results of the testing performed with the components procured for the Mazda engine.

\subsection{Task VII Prototype Engine - Procurement/Assembly - NASA 1007R}

The engine which will ultimately pursue the goals of the better efficiencies discovered in Phase $I$ is the NASA-owned 1007R engine built by John Deere. Completion of this contract entails modifying four different components of a 1007R engine with thermal-barrier coatings. Actual 1007R engine assembly and testing will be performed by John Deere and is not included in this project. The following is a description of the modifications of the 1007R components.

\subsubsection{Rotor}

One 1007R rotor was machined to remove $0.762 \mathrm{~mm}(0.030 \mathrm{inch})$ of material on the rotor combustion faces with the exception of a $9.5 \mathrm{~mm}(0.375$ inch) land at each apex (such that the apex seals are fully supported by the parent rotor material) and a $0.762 \mathrm{~mm}(0.030 \mathrm{inch})$ land along the side lands. A thin band of parent material was left untouched during machining around the lip of the combustion chamber (figure 5.7.0-1). A $0.762 \mathrm{~mm}(0.030$ inch) layer of plasma-sprayed zirconia lincluding a $0.127 \mathrm{~mm}(0.005$ inch) layer of NiCrAlY bond coat] was then sprayed onto the resultant pocket in the faces of the rotor and the high spots removed. The surface was then densified. The coating densification process was the non-toxic, low-temperature process developed by Adiabatics, Inc. 
ORIGMAL PROE is

OF POOFi QURLITY

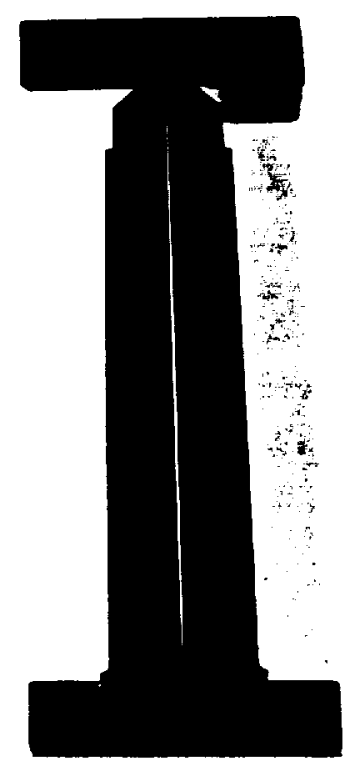

$$
\text { AI }-C / 152-2 \mathrm{~A}
$$

Figure 5.6.2-4. Warped Standard Cast Iron Apex Seals Tested vith coated cast Iron Rotor Housing. 


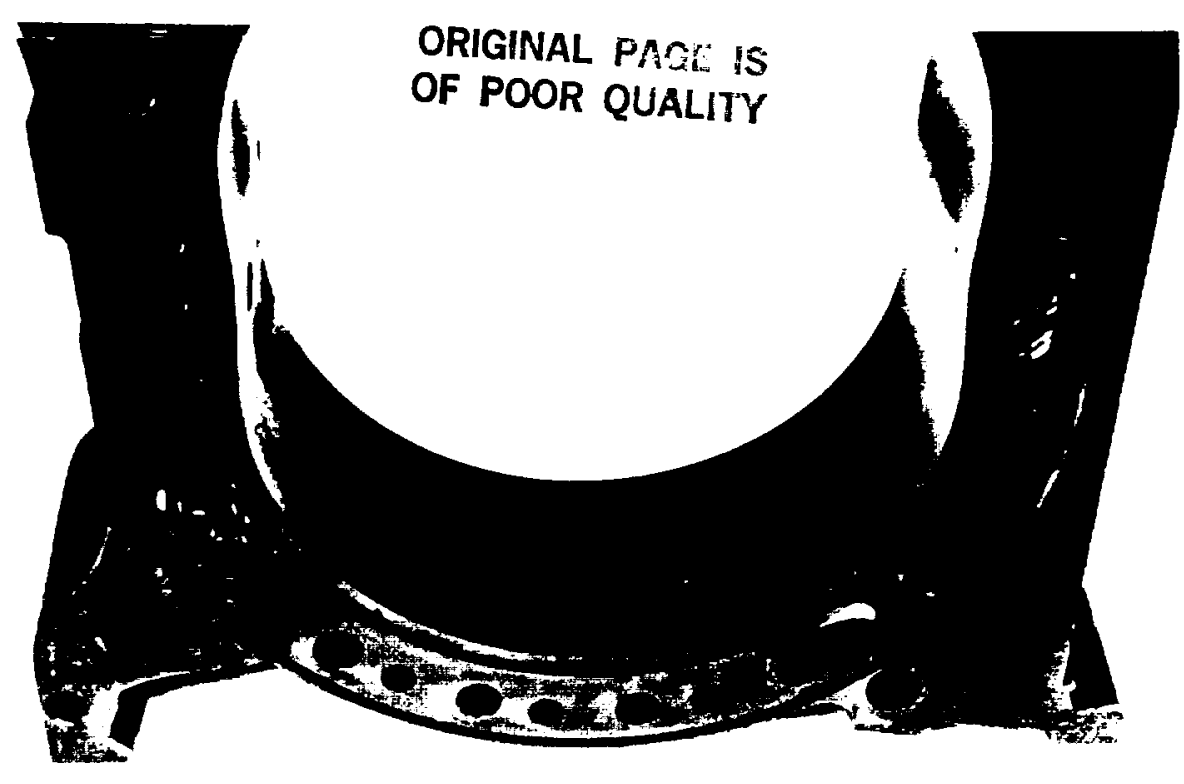

$A I-C / 152-5 A$

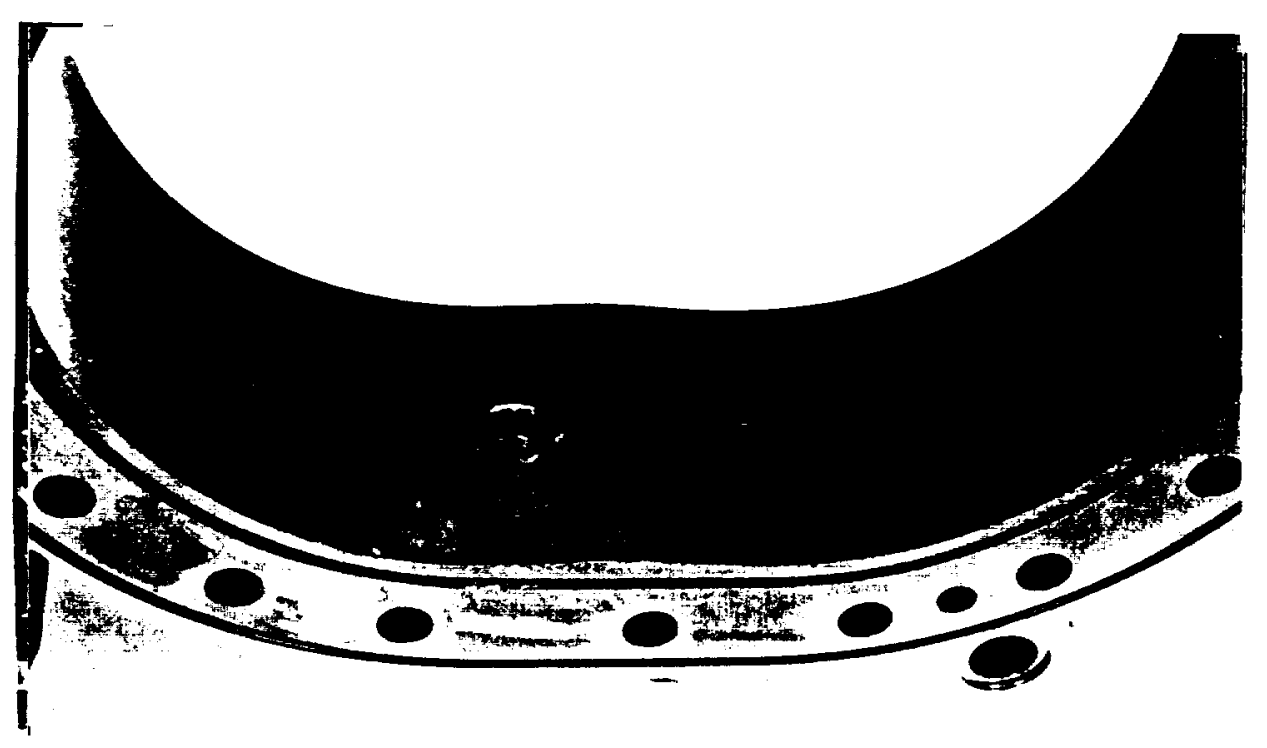

$A I-C / 15=-6 ?$

Figure 5.6.2-5. Coated Cast Iron Rotor Housing After 32.3 Hours of Testing. 


$$
\begin{aligned}
& \text { ORALP } \\
& \text { OF POOR }
\end{aligned}
$$

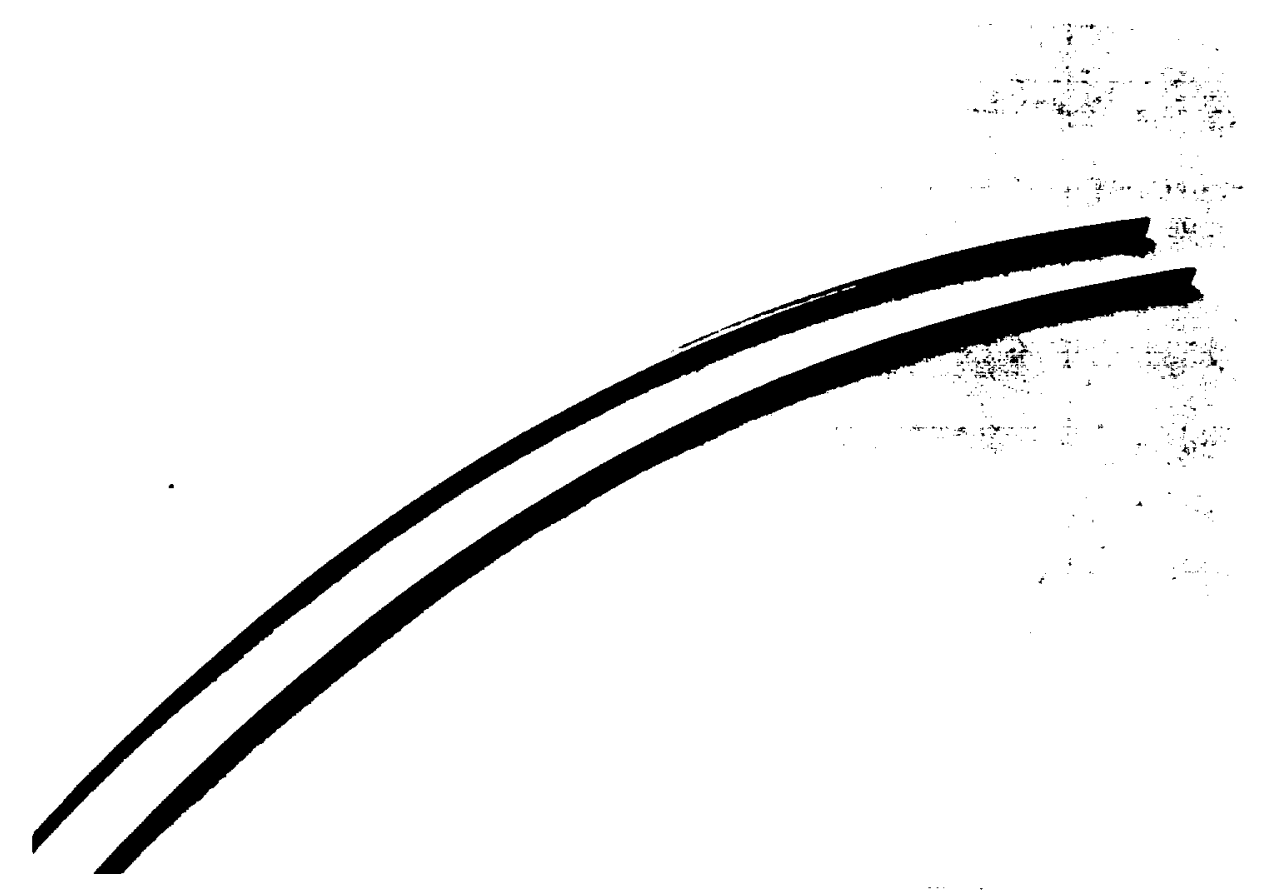

$A I-C / 152-3 A$

Figure 5.6.2-6. Adiabatics' slurry coating on a Mazda side seal (below) Compared to a stock side seal (top) After 32.5 Hours of Engine Testing. 


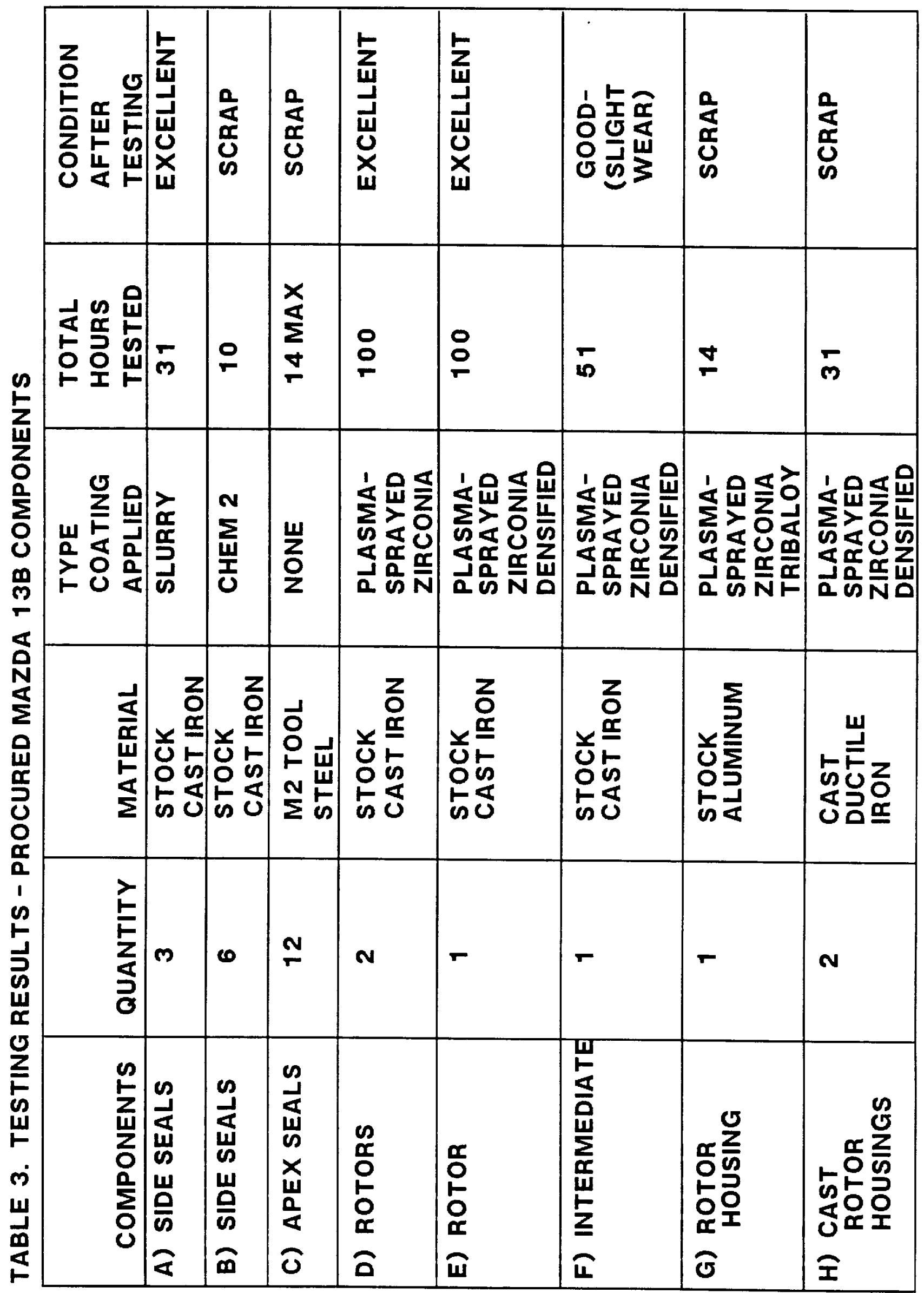


ORIGLA: PUAS

OF POOR QUAE:YY

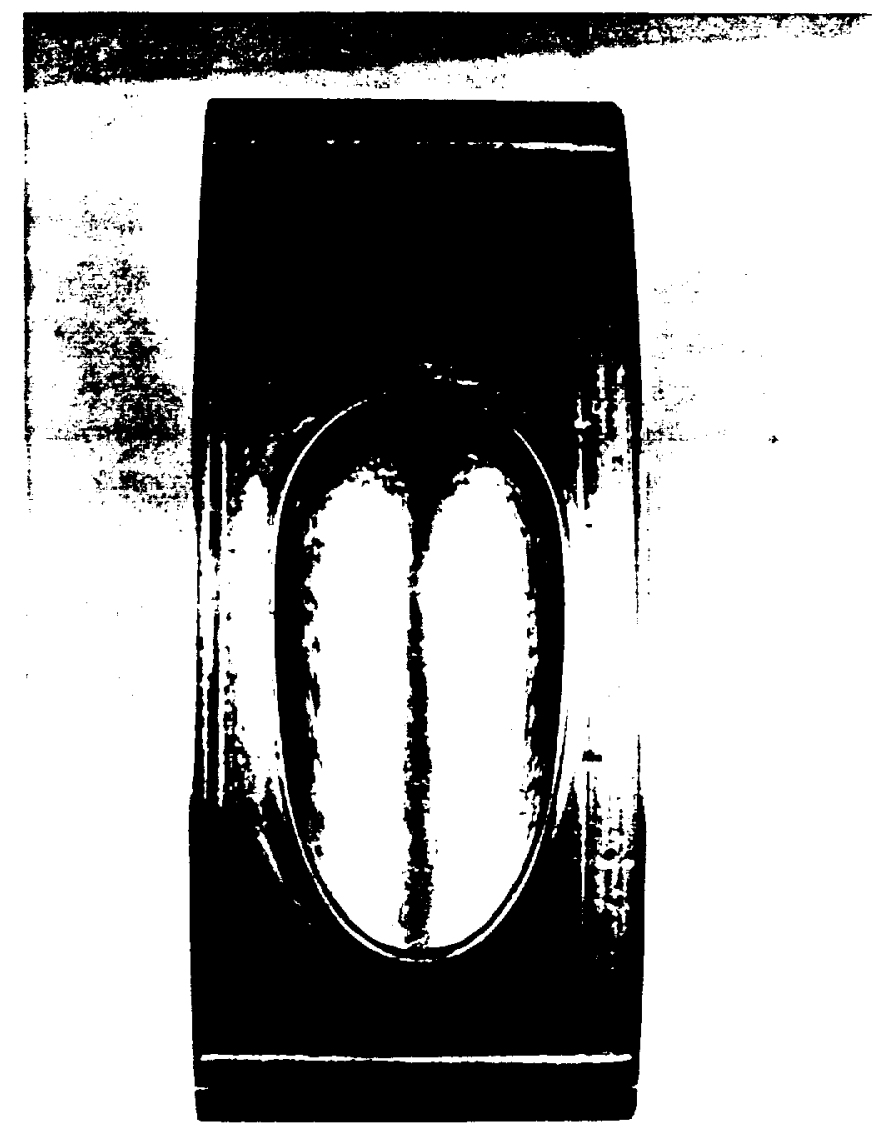

$A I-C / 144-6$

Figure 5.7.0-1. 1007R Rotor After Machining Process Showing the Lip of Untouched Material Around the Combustion Chamber. 
Photographs in figures 5.7.0-1 and 5.7.0-2 show the rotor in the different phases of coating application. Figure 5.7.0-3 is a drawing which details the coating on the rotor.

\subsubsection{Side Housings}

Both a front and a rear aluminum 1007R side housings were coated with thermal-barrier coatings. Since these pieces are made of aluminum they could not be densified with chrome oxide at $537.8 \mathrm{C}(1000 \mathrm{~F})$. Obviously, the aluminum will not withstand such an extreme densification temperature. Therefore an alternate wear coating was required.

The alternative was to spray the insulative coating first and then coat the insulation with a wear coating. More specifically, spray on the zirconia and then spray a wear surface directly on top the zirconia. The wear coating selected was Tribaloy 800 (the same type of coating combination used in modifying the aluminum Mazda rotor housing).

Two attempts were made to apply the zirconia/Tribaloy 800 combination onto the side housings. The first attempt was as follows:

1. $0.889 \mathrm{~mm}(0.035$ inch) of parent material was machined from the face of each side housing in the area where the housing is exposed to the rotor.

2. The housing was sent to APS Material, Inc. where a $0.127 \mathrm{~mm}(0.005$ inch) layer of plasma-sprayed NiCrAlY bond coat plus a $0.508 \mathrm{~mm}(0.020 \mathrm{inch}$ ) layer of plasma-sprayed zirconia was applied.

3. After the zirconia coating application the pieces were sent to a machine shop where zirconia was ground to ensure dimensional correctness.

4. After grinding, the housings were sent to Stellite, Inc. to have the wear coating applied. A jet coat process was used to apply more than a $0.254 \mathrm{~mm}$ ( 0.010 inch) layer of Tribaloy 800 .

At this point the coating process was stopped because Stellite, Inc. could not get the T. Pictures of the Mazda engine mounted in the test cell can be seen in figure 5.1.3-1.

The fifth operation was the test itself. Engine testing started with a compression test. The compression tester takes six (6) measurements (one for each rotor face). Next, the engine was started and run through the break-in cycle which consisted of running at varying speeds with light to no-load. During this run all systems were checked to make sure they were functioning properly.

A test was to be run to develop inch) layer of plasma-sprayed zirconia and a layer exceeding $0.254 \mathrm{~mm}$ ( 0.010 inch) thick of plasma-sprayed Tribaloy 800 were applied. The drawing in figure 5.7.1-1 details the coating applied to the side housings.

2. After coating the side housings were ground and 1 apped.

One of the 2 side housing completed the grinding and lapping operation successfully. Unfortunately, the other side housing was under sprayed and 


\section{ORGMAL \\ OF POOR QuAnTY}

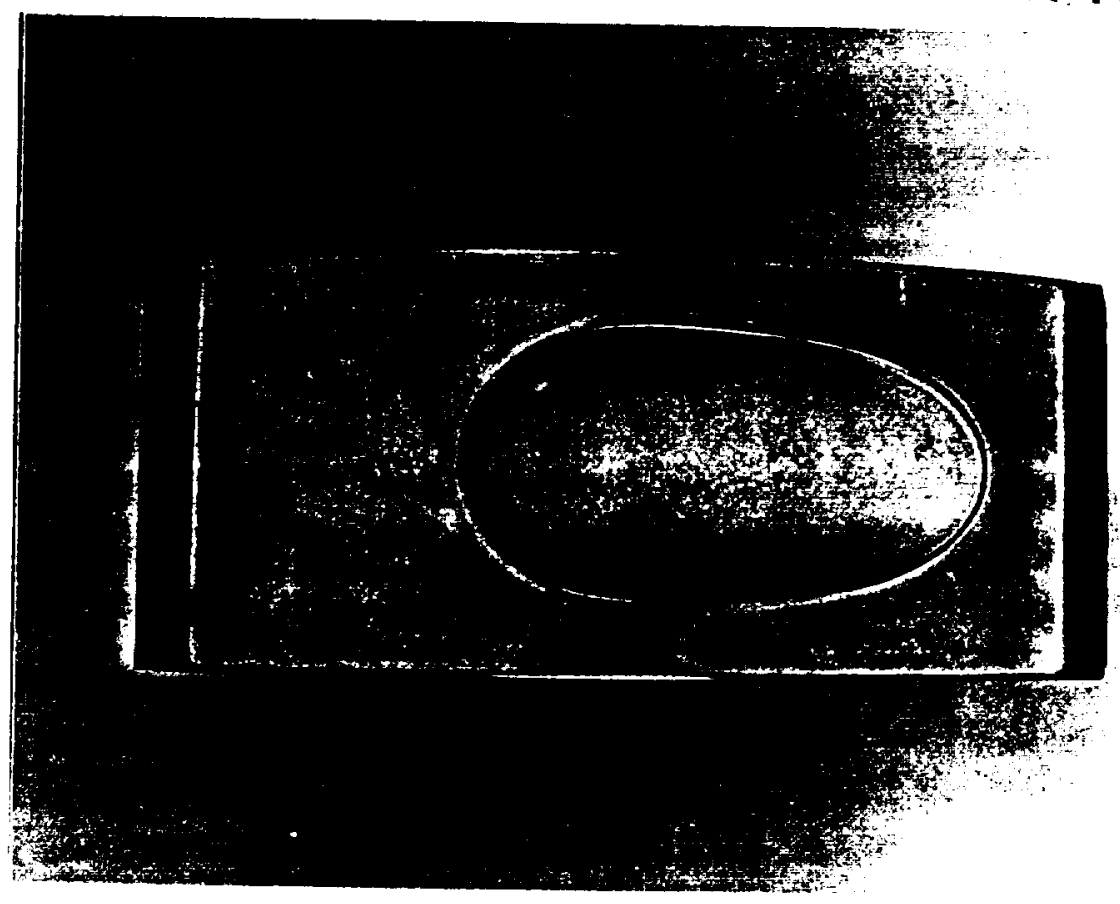

(a)

$\mathrm{AI}-\mathrm{C} / 145-14 \mathrm{~A}$

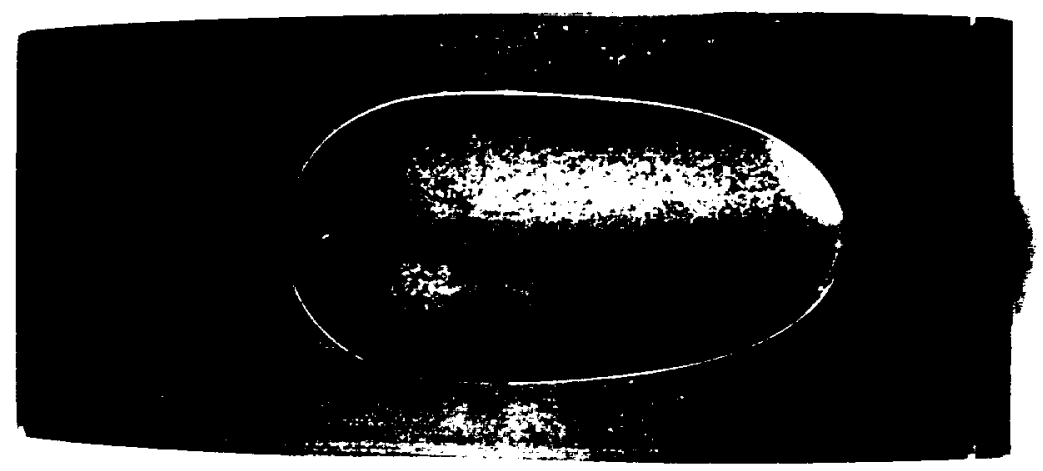

(b)

$A I-C \cdot 145-152$ $\begin{array}{ll}\text { Figure 5.7.0-2. } & \text { loo7f Rotor Shown (a) Zfter zirconia application } \\ & \text { and (b) After Zirconia Densification. }\end{array}$ 


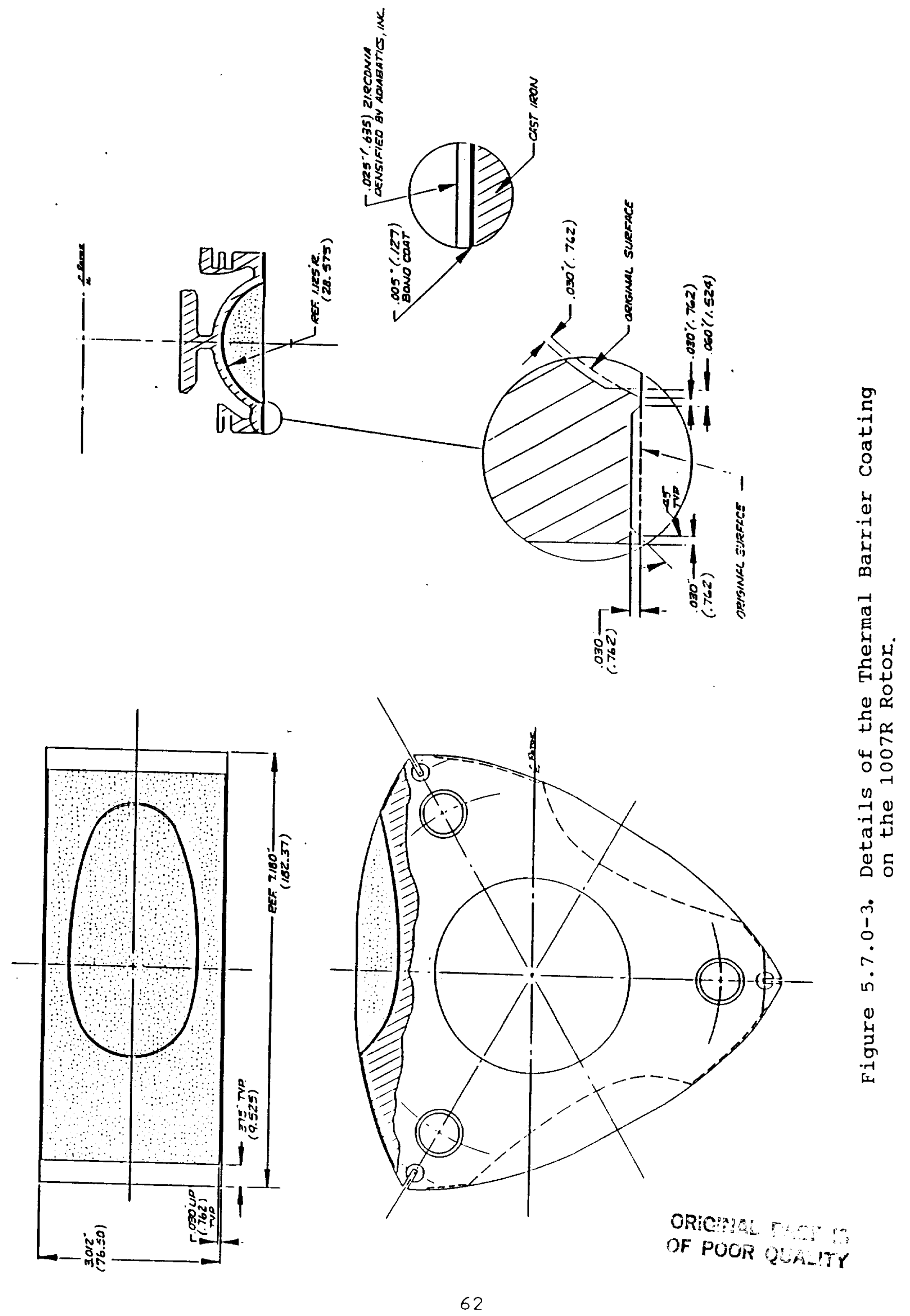



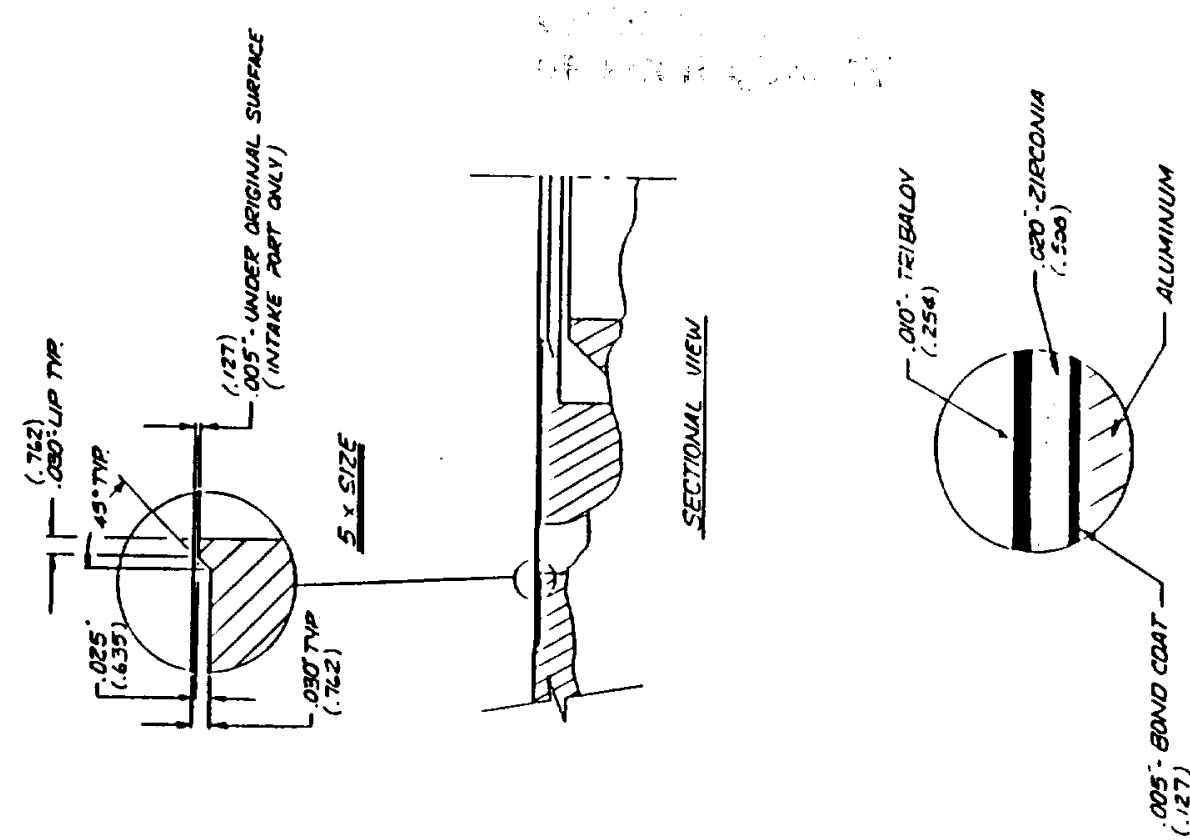

5

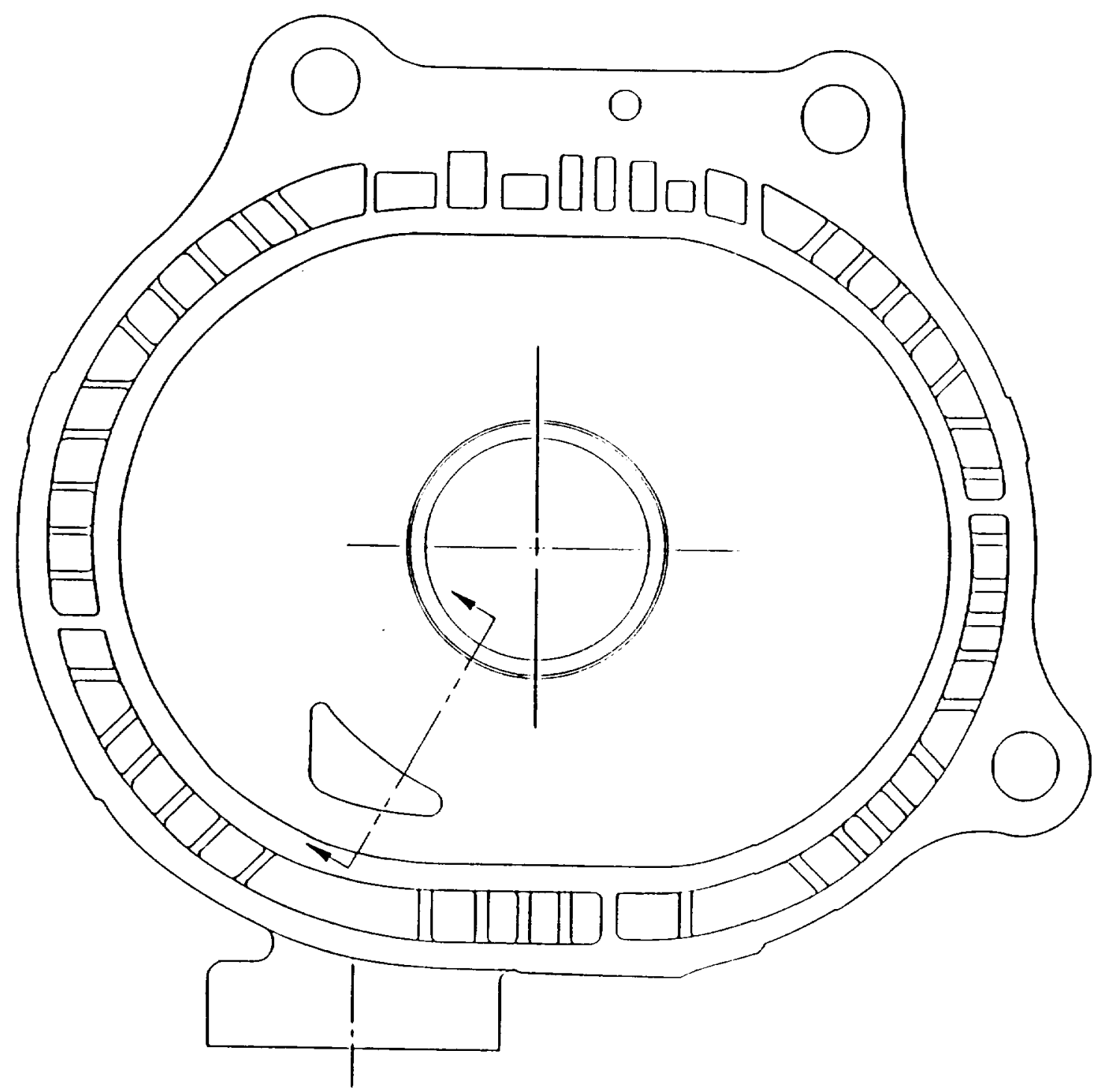

点

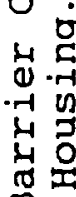

$\infty$

멀

总豆

世

吃

.

苗

$+0$

1) 
therefore was shipped back to APS Material Inc. to have additional Tribaloy 800 applied. This housing was then reground and lapped. Pictures in figure 5.7.1-2 show the 1007R side housing after machining and after grinding and lapping. After lapping was completed Adiabatics Inc. noticed some cracking around the crankshaft hole in the area which had been built up (figure $5.7 .1-3)$.

\subsubsection{Rotor Housing}

The aluminum $1007 \mathrm{R}$ rotor housing was coated with the same zirconia/Tribaloy 800 combination used on the aluminum side housing.

1. The rotor housing was sent to Eonic, Inc. where $0.889 \mathrm{~mm}(0.035$ inch) of parent material was removed.

2. The housing was sent to APS Materials, Inc. where a $0.127 \mathrm{~mm}(0.005$ inch) bond coat plus $0.508 \mathrm{~mm}(0.020$ inch) of zirconia was applied to the trochoid contour and $0.635 \mathrm{~mm}(0.025 \mathrm{inch})$ of zirconia to the exhaust port.

3. With the zirconia applied the housing was then sent back to Eonic where the coating on the trochoid contour was ground. The trochoid was ground to 0.254 $\mathrm{mm}(0.010$ inch) over size (per side) to ensure dimensional correctness and ensure room for the wear coating application.

4. After grinding, the rotor housing was sent back to APS Material, Inc. for the application of a wear coating. Tribaloy 800 was plasma-sprayed on top of the zirconia more than $0.254 \mathrm{~mm}$ ( 0.010 inch) thick.

5. After applying the Tribaloy, the housing was sent back to Eonic for final grinding and lapping of the Tribaloy coating back to original dimensions.

A drawing detailing this coating is shown in figure 5.7.2-1. Pictures in figure 5.7.2-2 show the rotor housing in different phases of coating application.

Table 4 summarizes the components procured for the assembly of the insulated 1007R engine.

\subsection{Task VIII Exhaust Energy Utilization}

As an internal combustion engine is made more adiabatic a greater amount of exhaust enthalpy will flow from the engine. That is, some of the energy which would have been lost to engine coolant, lubrication, radiation and convection will appear in the exhaust gas in the form of a higher exhaust temperature. This higher exhaust temperature represents a large energy flow which can be recovered.

An analytical assessment was made of compounding a turbocharged 1007R John Deere rotary engine. The engine specifications and data for 2 test conditions are tabulated in Tables 5, 6, and 7. These data were employed in a rotary engine simulation which works on an energy balance of the engine, and was used to determine additional energy which would become available as the engine was insulated and the coolant was removed. An energy balance of the baseline noninsulated, cooled engine appears in Table 8 . Changes (percentages) in heat rejection to the oil, coolant, and radiation due to insulation and coolant 
ORICERSE. POS

OF POOR QUiniTY

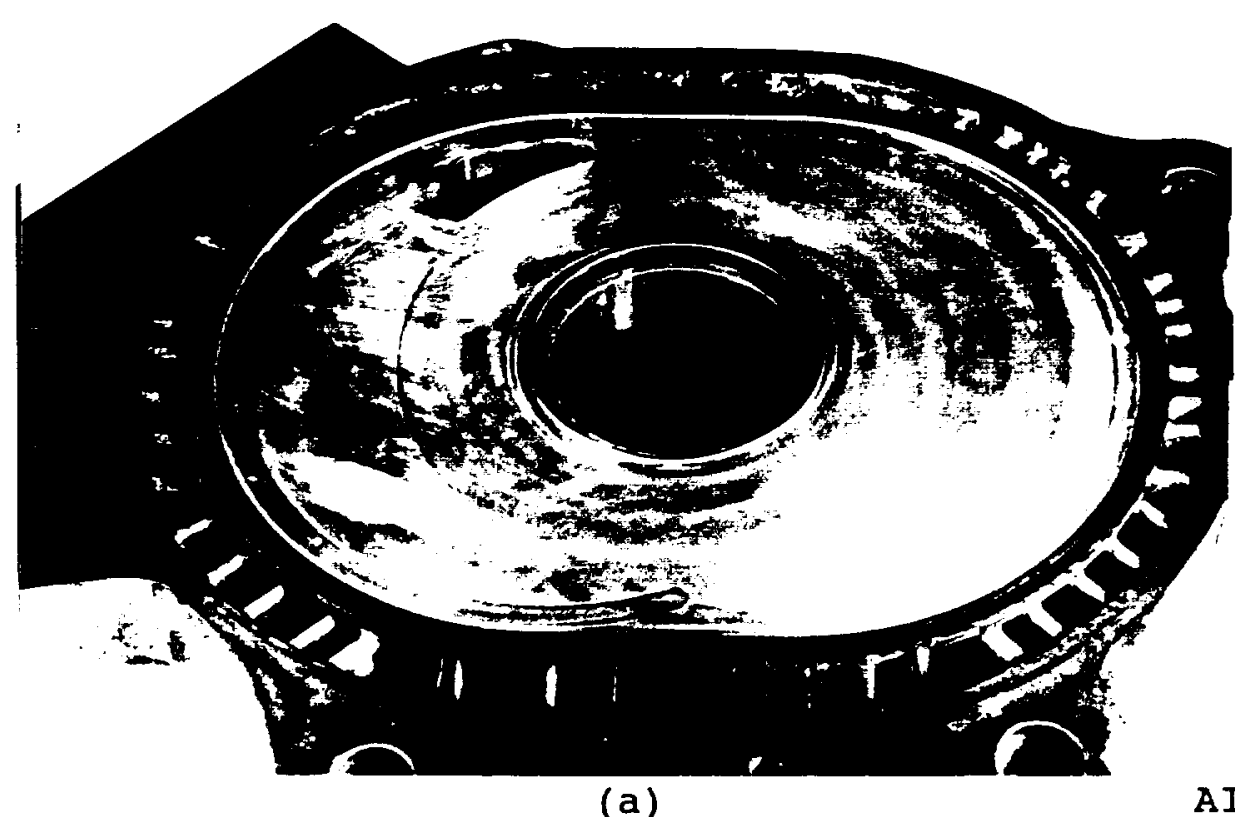

AI-C/141-19

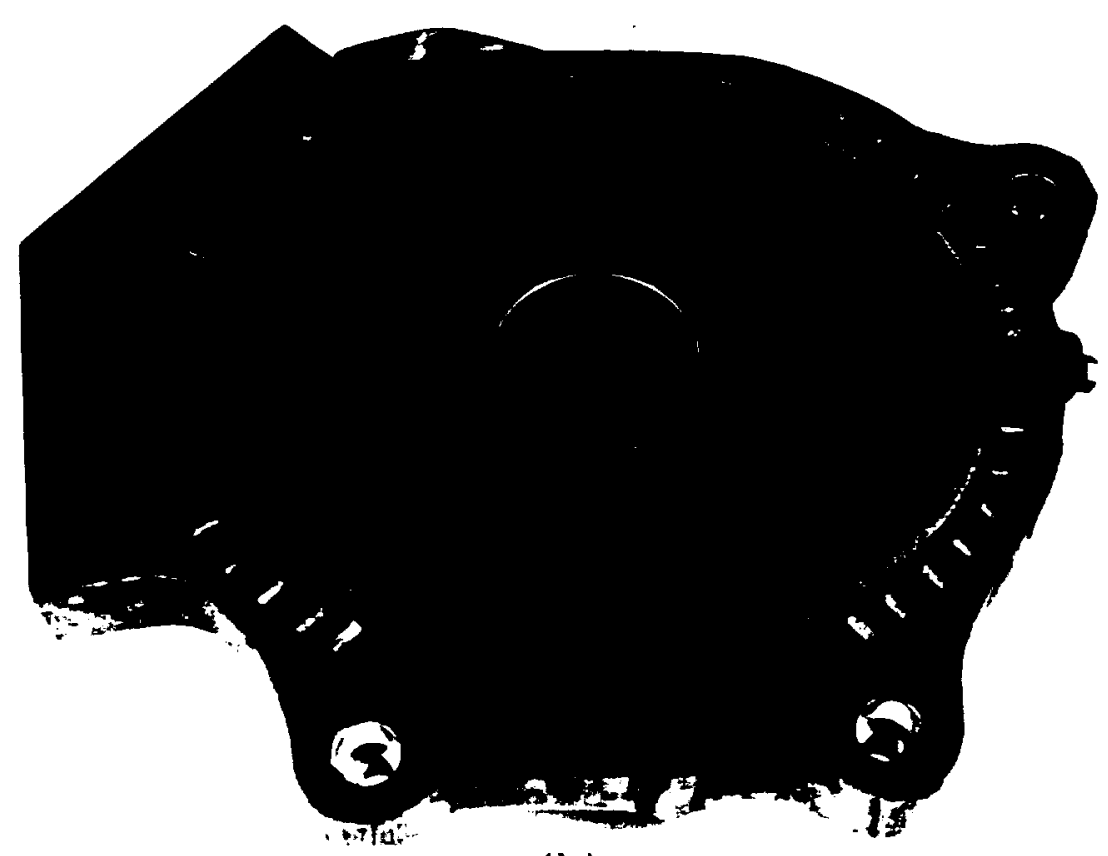

(b)

$\mathrm{AI}-\mathrm{C} / 155-12 \mathrm{~A}$

Figure 5.7.1-2. 1007R Side Housing After Maching (a) and Final Lapping (b). 
ORLE:

OF POOR QU⿴囗十⺝

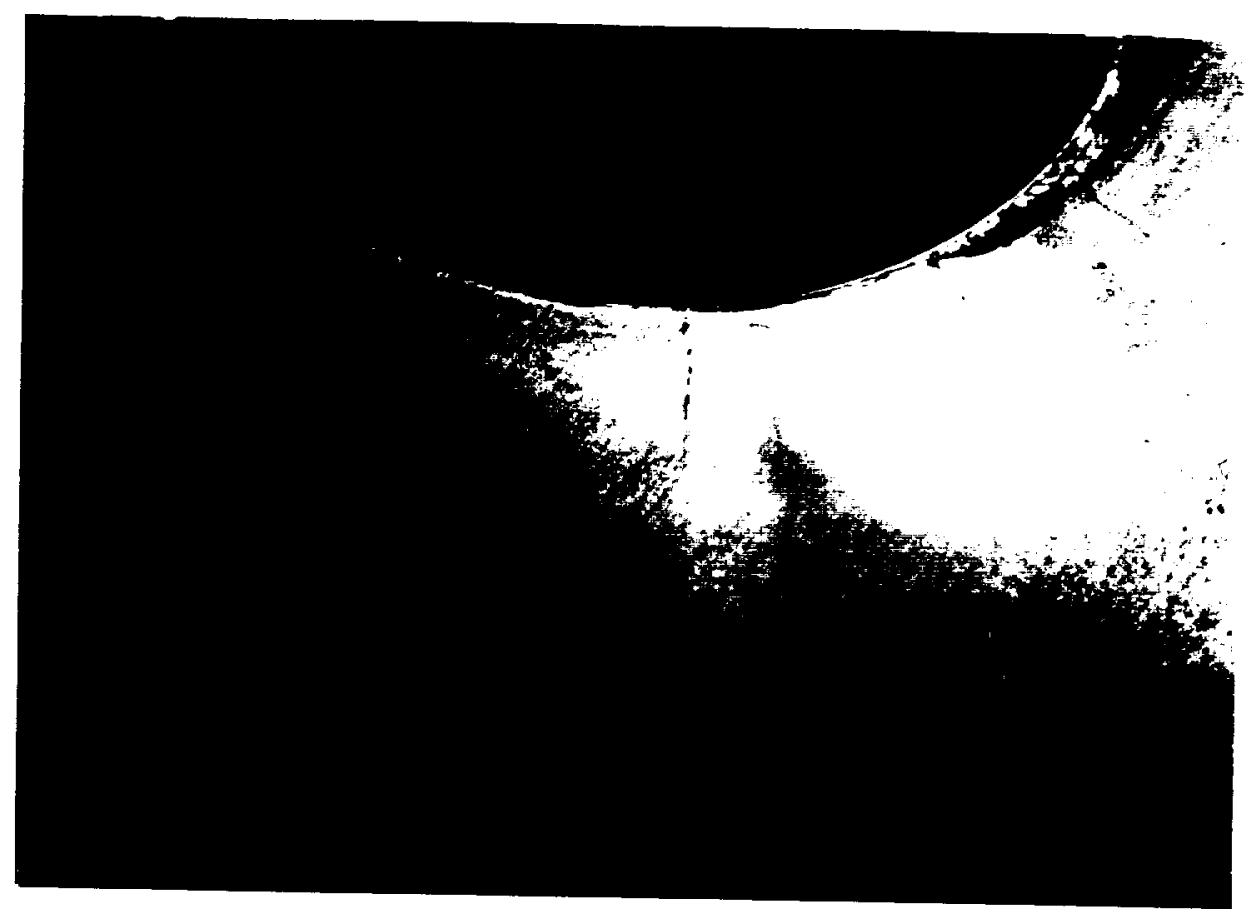

AI-C/155-17A

Figure 5.7.1-3. Cracking Around the Crankshaft Hole of 1007R Side Housing After Final Lapping. 

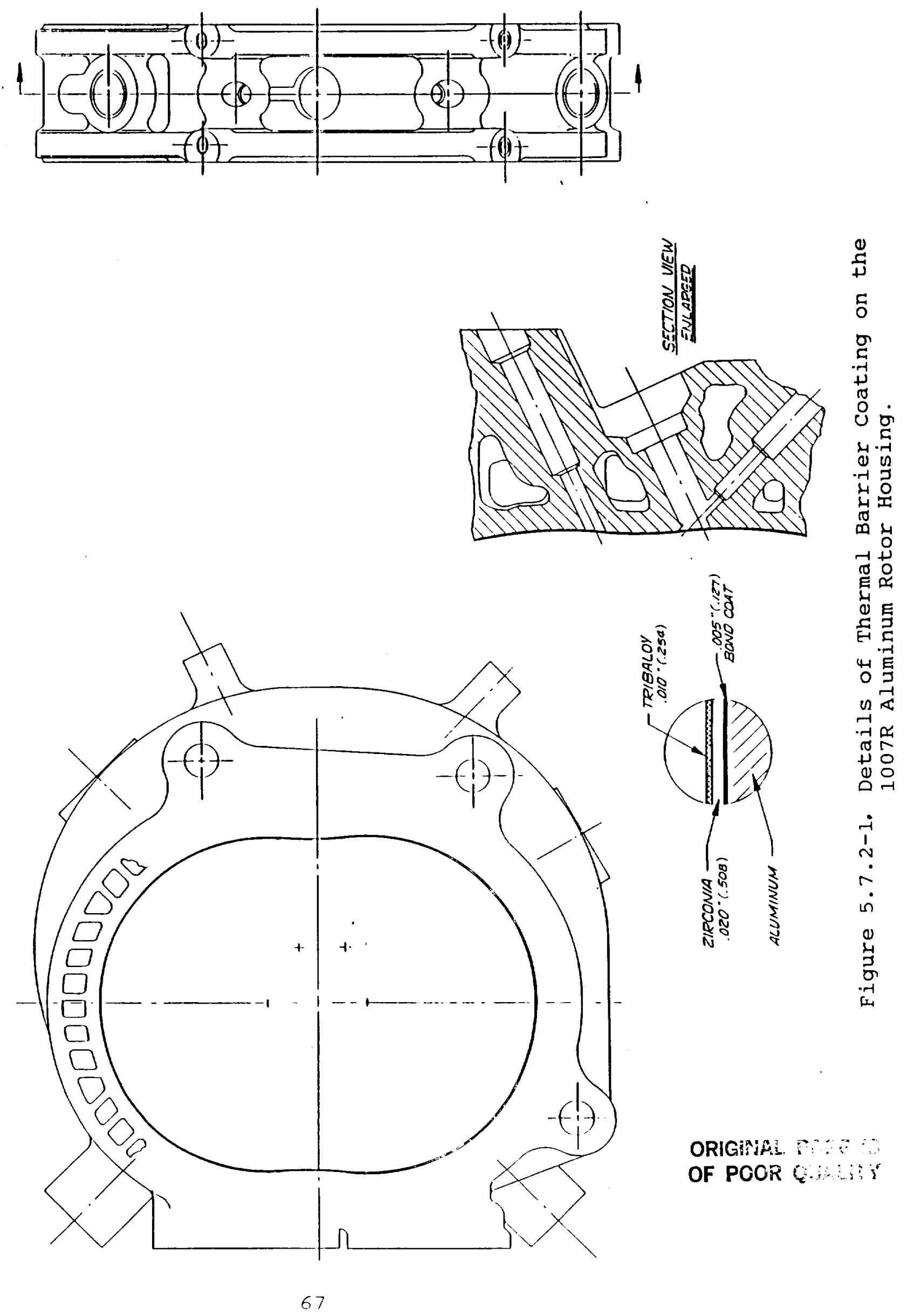
ORIGHAL PAL IS

OF POGR QUALITY

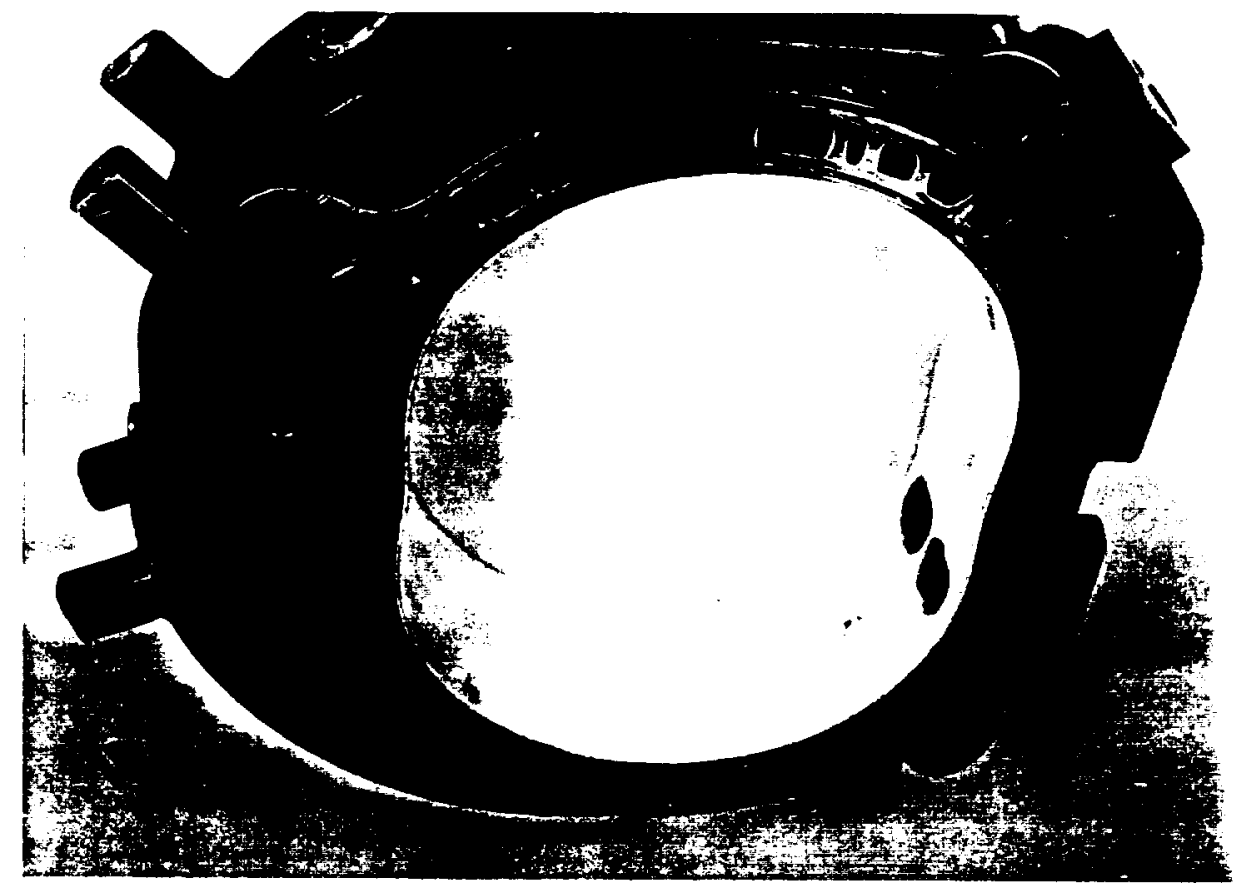

(a)

$A I-C / 146-20$

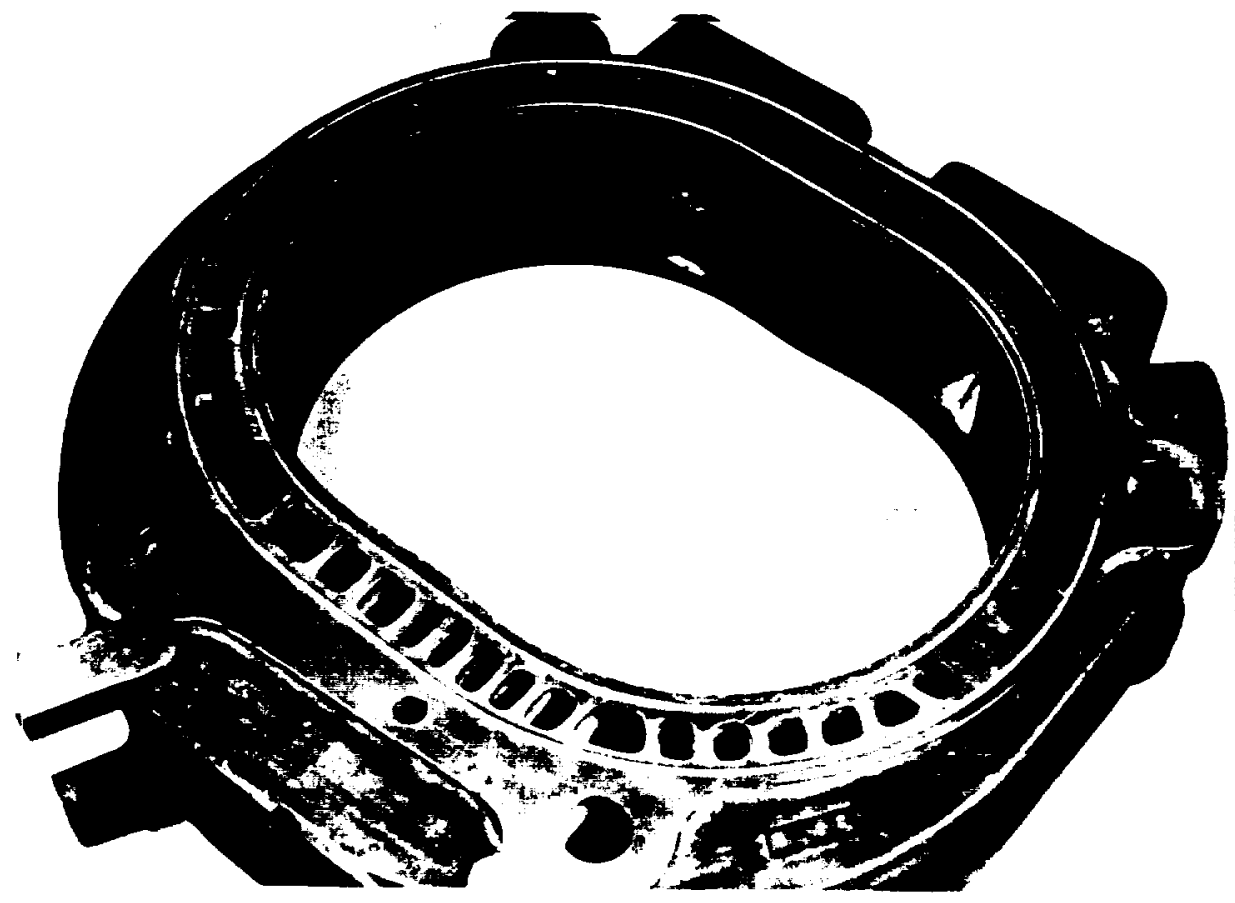

(b)

$A I-C / 152-17 A$

Figure 5.7.2-2. 1007R Rotor Housing Shown After Zirconia (a) and Tribaloy 800 (b) Application. 
OPOC:

OE FuE C i o

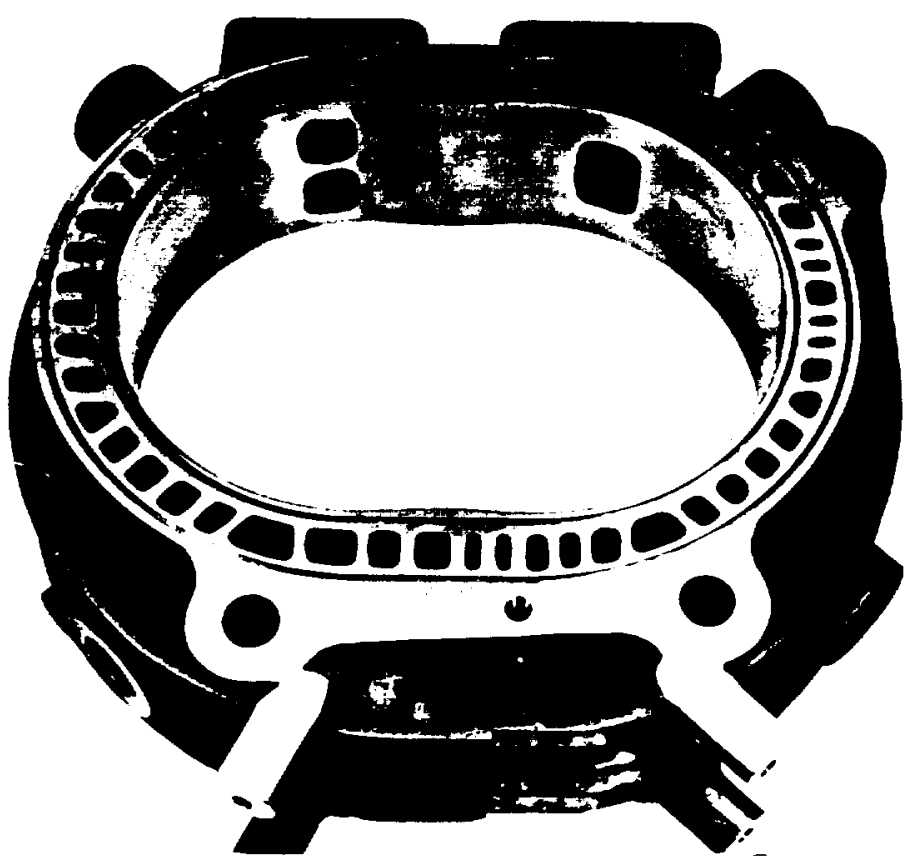

$\mathrm{AI}-\mathrm{C} / 155-15 \mathrm{~A}$

Figure 5.7.2-2 Cont. 1007R Rotor Housing After Final Lapping. 


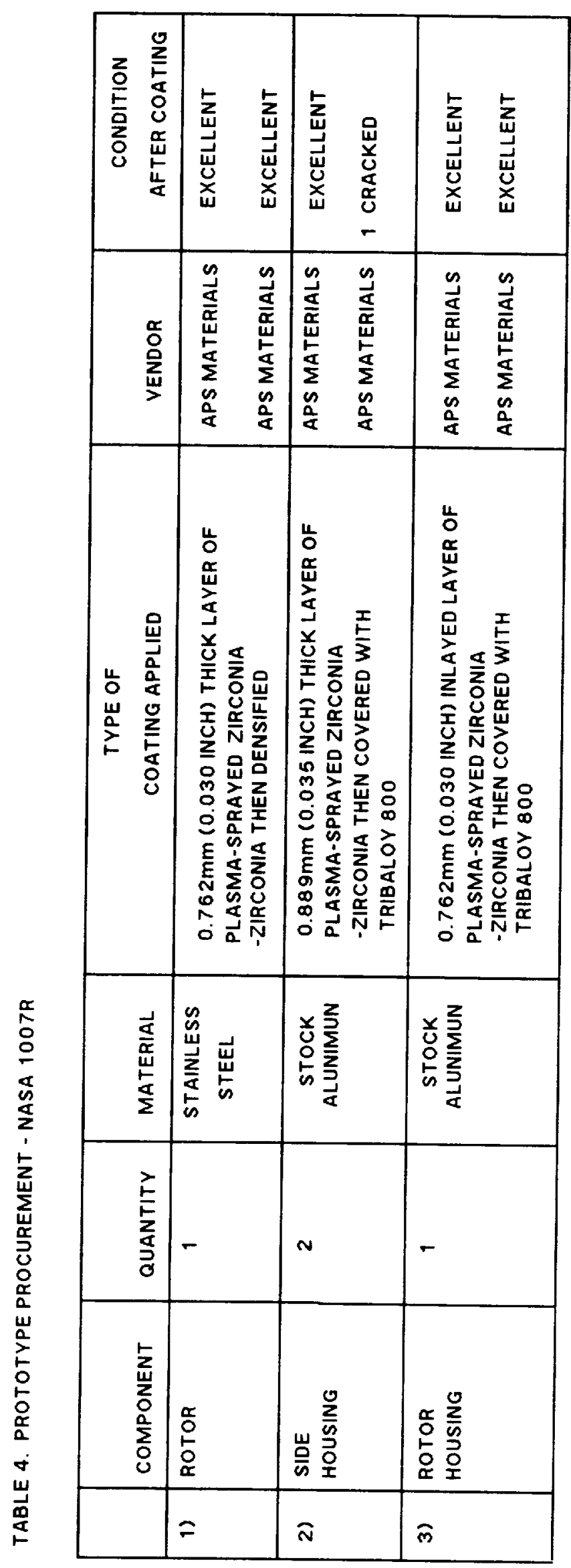


Table 5. 1007R Baseline Engine Basic Engine Configuration

\begin{tabular}{|c|c|}
\hline ENGINE TYPE & Rotary Turbocharged DISC \\
\hline ECCENTRICITY (in) & 0.607 \\
\hline TROCHOID GENERATING RADIUS (in) & 4.221 \\
\hline CHAMBER DEPTH (in) & 3.036 \\
\hline DISPLACEMENT (in' ) & 40.42 \\
\hline COMPRESSION RATIO & 7.500 \\
\hline PORT 'TIMING (deg • ATC) : & -626.3 \\
\hline INTAKE PORT OPENS & -229.5 \\
\hline INTAKE PORT CLOSES & 208.7 \\
\hline EXHAUST PORT OPENS & 610.5 \\
\hline EXHAUST PORT CLOSE & \\
\hline
\end{tabular}


TABLE 7 JOHN DEERE TEST DATA

\author{
ENGINE 0701-3 \\ COMPRESSION RATIO: 7.5 \\ TURBOCHARGER: AIRESEARCH T04, $1.3 \mathrm{~A} / \mathrm{R}$
}

\begin{tabular}{|c|c|c|c|}
\hline POINT NO. & - & 54 & 57 \\
\hline ENGINE SPEED & RPM & 7990 & 8003 \\
\hline LOAD & $1 \mathbf{b}$ & 102.6 & 120.6 \\
\hline BRAKE POWER & HP & 136.6 & 160.9 \\
\hline BMEP & psi & 167.6 & 197.0 \\
\hline BSFC & $1 \mathrm{~b} / \mathrm{HP}-\mathrm{hr}$ & 0.5098 & 0.5066 \\
\hline FUEL-AIR RATIO & - & 0.0378 & 0.0417 \\
\hline AIR FLOW & $1 \mathrm{~b} / \mathrm{hr}$ & 1840 & 1950 \\
\hline FUEL & - & JET $A$ & JET $A$ \\
\hline T TEST CELL AMB & $F$ & 97 & 88 \\
\hline T AIR PLENUM & $\mathbf{F}$ & 83 & 76 \\
\hline T AIR FILTER & $F$ & 82 & 74 \\
\hline T AIR BOTTLE & $F$ & 80 & 72 \\
\hline $\mathrm{T}$ COMP IN & $\mathrm{F}$ & 81 & 73 \\
\hline T COMP OUT & $F$ & 263 & 272 \\
\hline T ENG IN & $\mathrm{F}$ & 119 & 119 \\
\hline P BAROMETRIC & in $\mathrm{Hg}$ & 29.84 & 29.88 \\
\hline$P$ COMP IN & in $\mathrm{H} 20$ & $-18 \cdot 5$ & $-21 \cdot 5$ \\
\hline$P$ COMP OUT & in $\mathrm{Hg}$ & 31.3 & 34.2 \\
\hline$P$ ENG IN & in $\mathrm{Hg}$ & 24.3 & 29.4 \\
\hline RPM TURBO & RPM & 99500 & 104060 \\
\hline FUEL FLOW, TOTAL & $1 \mathrm{~b} / \mathrm{hr}$ & 69.66 & 81.50 \\
\hline TUEL FLOW, PILTO & $1 \mathrm{~b} / \mathrm{hr}$ & 6.11 & 5.49 \\
\hline T FUEL, MAIN & C & 38 & 39 \\
\hline T FUEL, PILTO & $\bar{c}$ & 37 & 36 \\
\hline MAIN INJ PRES & psi & 10000 & 15000 \\
\hline PILOT INJ PRES & psi & 7000 & 7000 \\
\hline T TURBINE IN & $\mathrm{F}$ & 1423 & 1457 \\
\hline T TURBINE OUT & $\mathrm{F}$ & 1361 & 1425 \\
\hline $\mathrm{P}$ TURBINE IN & in $\mathrm{Hg}$ & 12.7 & 15.0 \\
\hline$P$ TURBINE OUT & in $\mathrm{H} 2 \mathrm{O}$ & -5.3 & -4.8 \\
\hline OIL FLOW & $\mathrm{gal} / \mathrm{min}$ & 4.61 & 4.87 \\
\hline P OIL & psi & 63 & 61 \\
\hline T ENG OIL IN & $\mathbf{F}$ & 173.4 & 174 \\
\hline T ENG OIL OUT & $\mathbf{F}$ & 213.2 & 217 \\
\hline $\mathrm{T} T / C$ OIL OUT & $\mathbf{F}$ & 192 & 195 \\
\hline COOLANT FLOW & $1 \mathrm{~b} / \mathrm{hr}$ & 1613 & 1599 \\
\hline $\mathrm{T}$ COOLANT IN & $\mathbf{F}$ & 177.8 & 175.1 \\
\hline T COOLANT OUT & $\mathbf{F}$ & 184.5 & 182.7 \\
\hline DELTA $T$ COOLANG & $\mathbf{F}$ & 7.0 & 7.6 \\
\hline P COOLANT IN & psi & 19.4 & 20.0 \\
\hline P COOLANT, ROT hsg & psi & 12.0 & 12.8 \\
\hline P COOLANT, DE hsg & psi & 10.5 & 10.8 \\
\hline P COOLANT OUT & psi & 8.0 & 8.4 \\
\hline T INTERCOOLER IN & $\mathrm{F}$ & 79.4 & 77 \\
\hline T INTERCOOLER OUT & $\mathrm{F}$ & 92.2 & 91 \\
\hline
\end{tabular}


TABLE 7 JOHN DEERE TEST DATA (Cont.)

ENGINE 0701-3

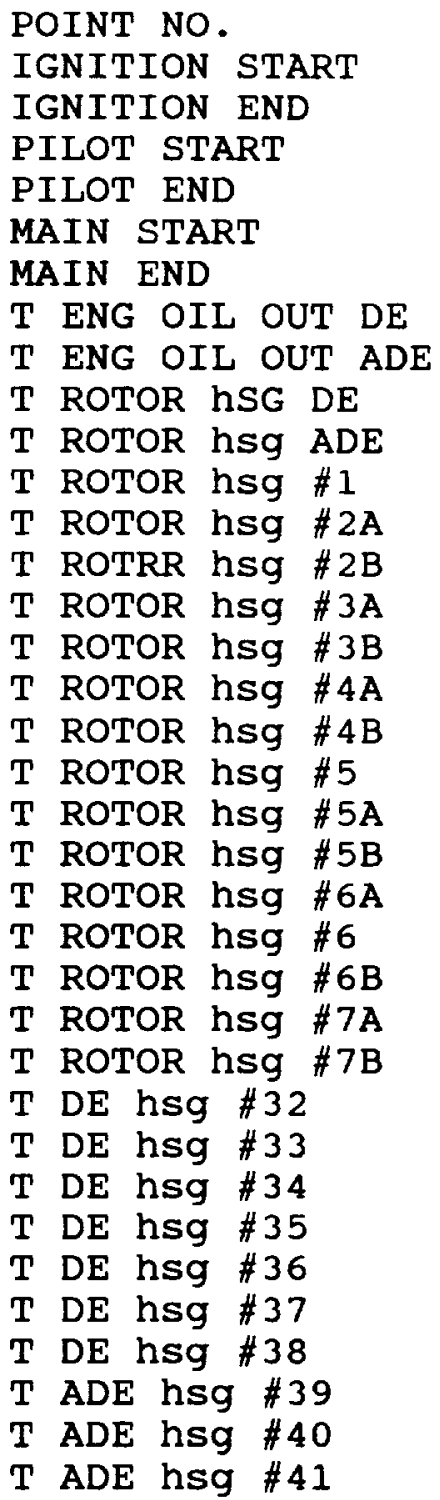

POINT NO.

IGNITION START

PILOT END

MAIN START

$T$ ENG OIL OUT DE

$T$ ENG OIL OUT ADE

T ROTOR hSG DE

$T$ ROTOR hsg ADE

T ROTOR hsg \#1

T ROTOR hsg \#2A

T ROTRR hsg \#2B

$T$ ROTOR hsg \#3A

$T$ ROTOR hsg \#3B

$T$ ROTOR hsg \#4A

T ROTOR hsg \#4B

T ROTOR hsg \#5

T ROTOR hsg \#5B

T ROTOR hsg \#6A

T ROTOR hsg \#6

T ROTOR hsg \#6B

T ROTOR hsg \#7A

$T$ ROTOR hsg \#7B

T DE hsg \#32

T DE hsg \#33

$T$ DE hsg \#34

T DE hsg \#35

T DE hsg \#36

Ds $\# 37$

T ADE hsg \#40

T ADE hsg \#41

\begin{tabular}{|c|c|c|}
\hline - & 54 & 57 \\
\hline deg BTC & 53 & 56 \\
\hline deg BTC & 7 & 5 ATC \\
\hline deg BTC & 52 & 55 \\
\hline deg BTC & 3 & 10 ATC \\
\hline deg BTC & 51 & 52 \\
\hline deg BTC & $8 \mathrm{ATC}$ & 10 \\
\hline$F$ & 238 & 243 \\
\hline$F$ & 217 & 221 \\
\hline $\mathrm{F}$ & 360 & 377 \\
\hline$F$ & 379 & 392 \\
\hline $\mathrm{F}$ & 207 & 204 \\
\hline $\mathrm{F}$ & 223 & 221 \\
\hline$F$ & 220 & 219 \\
\hline$F$ & 238 & 236 \\
\hline $\mathrm{F}$ & 230 & 228 \\
\hline $\mathrm{F}$ & 231 & 235 \\
\hline$F$ & 244 & 253 \\
\hline $\mathrm{F}$ & 196 & 191 \\
\hline $\mathrm{F}$ & 215 & 215 \\
\hline F & OUT & 212 \\
\hline $\mathrm{F}$ & 199 & 198 \\
\hline $\mathrm{F}$ & 190 & 188 \\
\hline F & 206 & 208 \\
\hline $\mathrm{F}$ & 191 & 192 \\
\hline $\mathrm{F}$ & 195 & 195 \\
\hline F & 192 & 194 \\
\hline F & OUT & OUT \\
\hline $\mathbf{F}$ & 223 & 228 \\
\hline F & 214 & 217 \\
\hline$F$ & 214 & 219 \\
\hline $\mathrm{F}$ & 196 & 197 \\
\hline $\mathbf{F}$ & 198 & 200 \\
\hline $\mathbf{F}$ & 199 & 201 \\
\hline $\mathbf{F}$ & 209 & 211 \\
\hline $\mathbf{F}$ & 199 & 201 \\
\hline
\end{tabular}




\section{TABLE 8. : ENERGY BALANCE (simulation)}

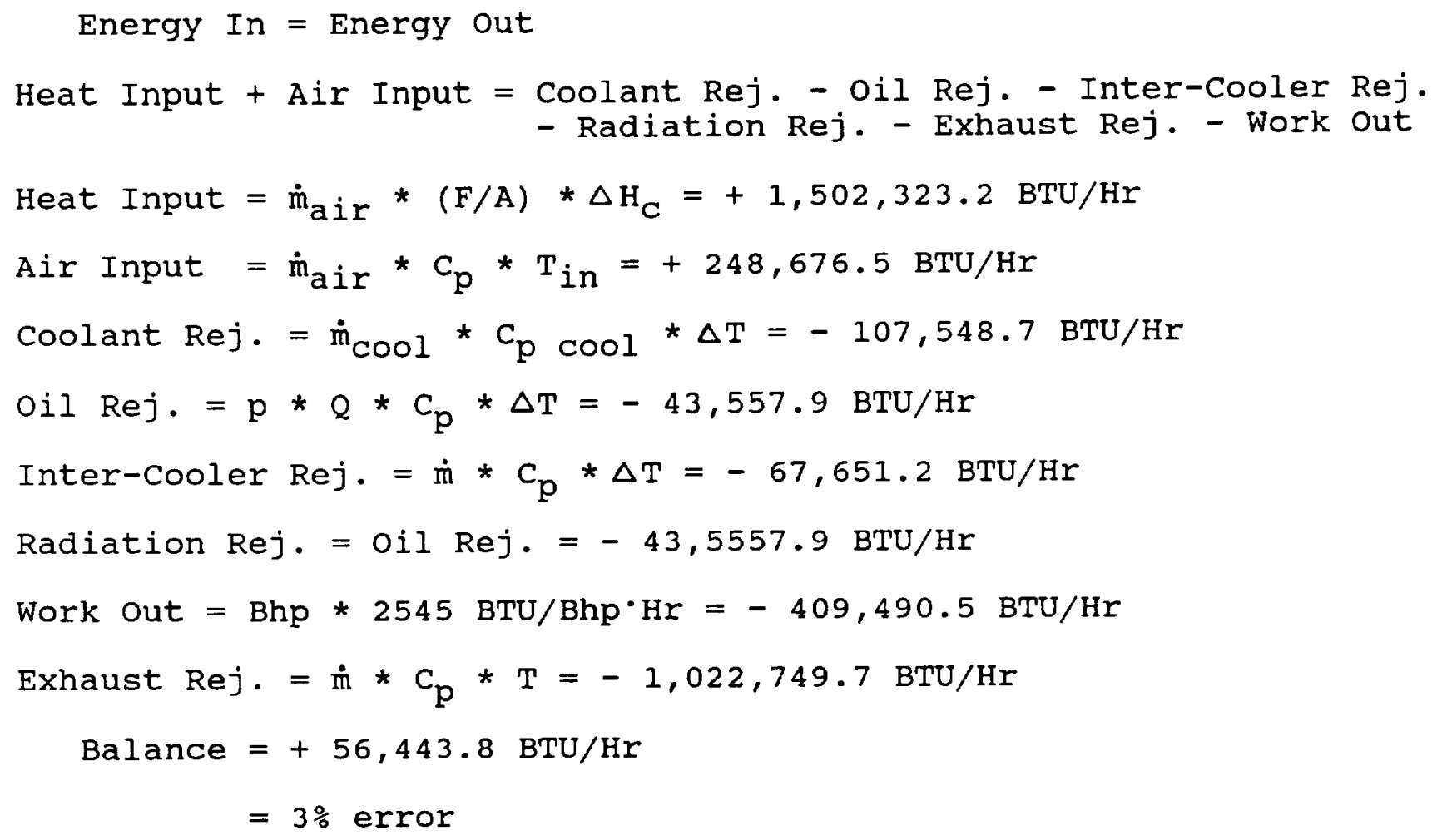

\section{Assumptions}

Fuel Enthalpy Neglected

Radiation Rej. = oil Rej. 
removal were obtained from a study performed by ADAPCO. It was decided that the percentage changes in heat rejection would be more approximate rather than the absolute changes reported by ADAPCO for addition of insulation and removal of engine coolant. These percentages were obtained from the heat transfer rates in Table 6.

The simulation was calibrated to the John Deere data (point 57) for a baseline. The output from the simulation appears as the baseline data in Table 9 .

The specific heat rejections to coolant and oil were then successively changed by the percentages developed from Table 6. The input and output for an insulated, cooled engine appears in Table 10. Input and output for the insulated, uncooled engine appears in Table 11.

The additional power in the exhaust is plotted in figure 5.8-1. A nearly linear relationship exists between $\%$ adiabacity and $\%$ power gain. Approximately $7.5 \%$ additional power becomes available for $20.8 \%$ adiabacity (insulated, cooled), and $14.9 \%$ additional power becomes available for $41.6 \%$ adiabacity (insulated, uncooled). A portion of this additional power can be recovered in the bottoming cycle. The amount of recovery then is dependent on the efficiency of the bottoming cycle used. As mentioned above a value of $50 \%$ was assumed. Then the recoverable power is shown in figure $5.8-1$ to be $3.75 \%$ of the rotary engine brake power for $20.8 \%$ adiabacity and $7.45 \%$ for $41.6 \%$ adiabacity.

This analysis indicated that a significant amount of additional power becomes available in the exhaust gas by adding thermal insulation to the engine and removing the engine coolant.

\subsection{Task IX Reporting}

Quarterly Technical and Progress Reports were submitted throughout the program. Each task was reported in each progress report. One copy of the Final Report draft shall be submitted for review in 1 ieu of the 4 copies specified.

\subsection{CONCLUSIONS}

1. Application of adiabatic (low heat rejection) engine technology to the rotary (Wankel type) engine is highly dependent upon the materials used for the basic engine components.

2. Fundamental work on increasing the permissible operating temperature of the apex seal/rotor housing tribological system is required before the adiabatic technology can be successfully applied to a complete engine.

3. Successful low heat rejection major engine components have been designed, analyzed, fabricated and tested in a Mazda gasoline rotary engine and low heat rejection components fabricated for the NASA 1007R stratified charge engine. The 1007R components are available for testing by John Deere's Rotary Engine Division. 
TABLE 9 BASELINE

\section{INPUT}

INLET TEMPERATURE - DEGREES F

INLET PRESSURE - IN HG ASB

INTAKE PRESSURE DROP - IN H2O

COMPRESSOR EFFICIENCY

INTERCOOLER COOLANT IN TEMP - F

INTERCOOLER EFFECTIVITY

BASELINE EXHAUST ENTHALPY - BTU/MIN

73.00
29.88
21.50
75.00
77.0
80.00
18095.30

OUTPUT

BMEP - PSI

FMEP - PSI

BSFC - LBS/BHP/HR

ISFC - LBS/IHP/HR

FUEL AIR RATIO

FRICTION HORSEPOWER

COMPRESSOR MASS FLOW - LBS/HR

197.0000

37.0000

0.5076

0.4272

0.0420

30.3000

COMPRESSOR PRESSURE RATIO

TURBINE PRESSURE RATIO

COMPRESSOR HORSEPOWER

ADDITIONAL POWER FOR TURBOCOMPOUNDING

19443.0000

COOLANT HEAT REJECTION - BTU/MIN

LUBE OIL HEAT REJECTION - BTU/MIN

INTERCOOLER HEAT FLOW - BTU/MIN

RADIATION HEAT REJECTION - BTU/MIN

ENGINE THERMAL EFFICIENCY

AMBIENT PRESSURE - IN HG

COMPRESSOR INLET

COMPRESSOR OUTLET

ENGINE INLET

TURBINE INLET

TURBINE OUTLET

AMBIENT TEMPERATURE - F

COMPRESSOR INLET

COMPRESSOR OUTLET

2.26

1.46

34.30

0.00

1792.000

673.000

1132.000

673.000

0.272

29.88

28.30

63.95

59.81

43.77

29.88

ENGINE INLET

TURBINE INLET

TURBINE OUTLET

73.

73.

258.

113.

1573 .

1410 . 


\section{TABLE 10 INSULATED COOLED ENGINE}

INPUT

INLLET TEMPERATURE - DEGREES $F$

73.000

INLET PRESSURE - IN HG ABS

29.880

INTAKE PRESSURE DROP - IN H2O

COMPRESSION RATIO

DESIRED FUEL AIR RATIO

APPARENT VOLUMETRIC EFFICIENCY

21.500

7.500

0.042

FRICTION REDUCTION PERCENTAGE

125.000

ISFC REDUCTION PERCENTAGE

COMPRESSOR EFFICIENCY

INTERCOOLER COOLANT IN TEMP - F

15.000

INTERCOOLER EFFECIVITY

COOLANT - SPECIFIC HEAT REJECTION

$-22.500$

75.000

77.000

80.000

8.821

3.573

LUBE - SPECIFIC HEAT REJECTION

18095.300

OUTPUT

\begin{tabular}{|c|c|}
\hline BMEP - PSI & 197.000 \\
\hline FMEP - PSI & 37.000 \\
\hline $\mathrm{BSFC}-\mathrm{LBS} / \mathrm{BHP} / \mathrm{HR}$ & 0.507 \\
\hline ISFC - LBS/IHP/HR & 0.427 \\
\hline FUEL FLOW - CU MM PER STROKE & 93 \\
\hline ACTUAL FUEL AIR RATIO & \\
\hline FRICTION HORSEPOWER & 30.30 \\
\hline COMPRESSOR MASS FLOW - LBS/HR & 1944.000 \\
\hline COMPRESSOR PRESSURE RATIO & 2.26 \\
\hline TURBINE PRESSURE RATIO & 1.460 \\
\hline COMPRESSOR HORSEPOWER & 34.30 \\
\hline ADDITIONAL POWER FOR TURBOCOMPOUNDING & 24.0 \\
\hline COOLANT HEAT REJECTION - BTU/MIN & 1120.000 \\
\hline LUBE OIL HEAT REJECTION - BTU/MIN & 564.000 \\
\hline INTERCOOLER HEAT FLOW - BTU/MIN & 1132.000 \\
\hline RADIATION HEAT REJECTION - BTU/MIN & 564.000 \\
\hline ENGINE THERMAL EFFICIENCY & 0.272 \\
\hline AMBIENT PRESSURE - IN HG & 29.88 \\
\hline COMPRESSOR INLET & 28.30 \\
\hline COMPRESSOR OUTLET & 63.95 \\
\hline ENGINE INLET & 59.81 \\
\hline TURBINE INLET & 43.77 \\
\hline TURBINE OUTLET & 29.88 \\
\hline AMBIENT TEMPERATURE - F & 73. \\
\hline COMPRESSOR INLET & 73. \\
\hline COMPRESSOR OUTLET & 258 . \\
\hline ENGINE INLET & 113. \\
\hline TURBINE INLET & 1573 . \\
\hline TURBINE OUTLET & 1410 \\
\hline
\end{tabular}


TABLE 11 INSULATED UNCOOLED ENGINE

\section{INPUT}

\author{
INLLET TEMPERATURE - DEGREES F \\ INLET PRESSURE - IN HG ABS \\ INTAKE PRESSURE DROP - IN H2O \\ COMPRESSION RATIO \\ DESIRED FUEL AIR RATIO \\ APPARENT VOLUMETRIC EFFICIENCY \\ FRICTION REDUCTION PERCENTAGE \\ ISFC REDUCTION PERCENTAGE \\ COMPRESSOR EFFICIENCY \\ INTERCOOLER COOLANT IN TEMP - F \\ INTERCOOLER EFFECIVITY \\ COOLANT - SPECIFIC HEAT REJECTION \\ LUBE - SPECIFIC HEAT REJECTION \\ BASELINE EXHAUST ENTHALPY - BTU/MIN
}

$$
\begin{array}{r}
73.000 \\
29.880 \\
21.500 \\
7.500 \\
0.042 \\
125.000 \\
15.000 \\
-22.500 \\
75.000 \\
77.000 \\
80.000 \\
6.510 \\
2.636 \\
18095.300
\end{array}
$$

\footnotetext{
197.0000

37.0000

0.5076

0.4272

93.5805

0.0420

30.3000

1944.0000

2.2600

1.4600

34.3000

24.0000

349.000

534.000

1132.000

534.000

0.272

29.88

28.30

63.95

59.81

43.77

29.88

73.

73.

258 .

113 .

1573 .

1410 .
}

COMPRESSOR HORSEPOWER

ADDITIONAL POWER FOR TURBOCOMPOUNDING

RADIATION HEAT REJECTION - BTU/MIN

ENGINE THERMAL EFFICIENCY

\author{
AMBIENT PRESSURE - IN HG \\ COMPRESSOR INLET \\ COMPRESSOR OUTLET \\ ENGINE INLET \\ TURBINE INLET \\ TURBINE OUTLET \\ AMBIENT TEMPERATURE - F \\ COMPRESSOR INLET \\ COMPRESSOR OUTLET \\ ENGINE INLET \\ TURBINE INLET \\ TURBINE OUTLET
}




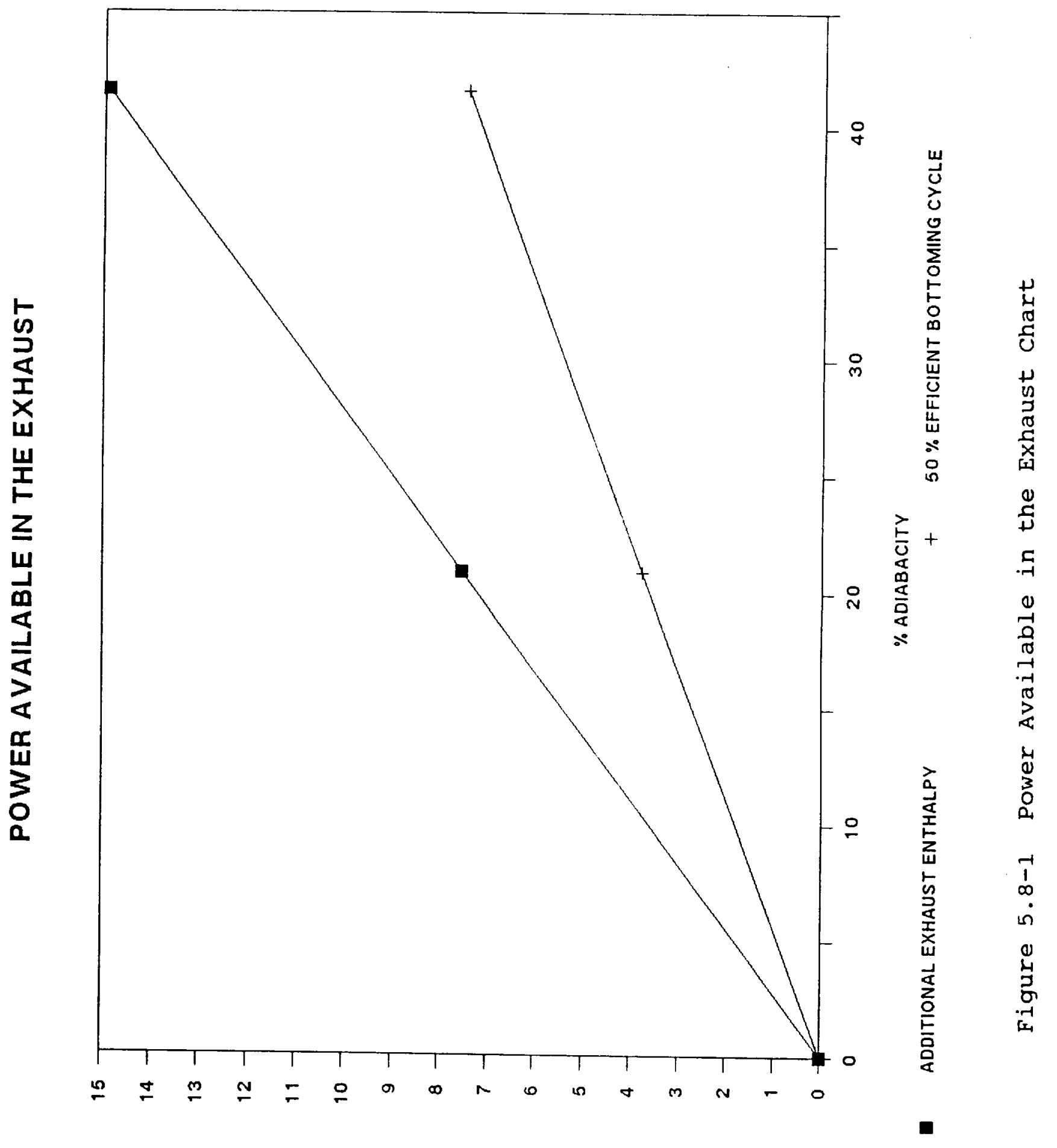

$\forall \exists \operatorname{MOd} 7 \forall N O I L I 00 \forall \%$ 
4. Application of insulating coatings to the engine's rotor, by plasma spraying partially stabilized zirconia (PSZ) followed by surface densification, has proven to be successful. A similar coating with high temperature chrome oxide densification to provide a good wear surface was successful on the Mazda cast iron side housings. However, application of the same material to the aluminum side housings and aluminum rotor housing of the $1007 \mathrm{R}$ engine is not possible because the processing temperatures required to obtain good wear surfaces are above the maximum permissible temperature to which the aluminum can be exposed.

5. A layered coating consisting of PSZ and Tribaloy 800 has been applied to the aluminum 1007R components to provide a thermal barrier insulating layer with a good tribological surface. Testing by John Deere is required to demonstrate the integrity of this coating.

6. Conclusive data on reduction of heat rejection is not available from the Mazda testing but will be generated when the components are tested in the stratified charge combustion engine by John Deere. Examination of the data from the Mazda engine testing with the insulated components result in the conclusion that dramatic reductions in heat rejection are achievable with todays coating technology. For instance, looking at Figure 5.6.1-8, adding only $0.75 \mathrm{~mm}$ of coating to the rotors raised the peak exhaust temperature $90 \mathrm{C}$. from 730 to 820 C. and Figure 5.6.1-3 shows that the temperature rise in the lube oil in the engine dropped more than 20 percent. Application of $0.5 \mathrm{~mm}$ of insulating coating to both sides of the Mazda intermediate housing (the two end housing sides were not coated) reduced the temperature rise in the lube oil by 50 percent (Figure 5.6.0-3). If similar results are observed on the stratified charge combustion engine, reductions of heat transfer to the lube oil of 75 percent or greater are expected.

7. Testing of the coated aluminum and coated cast iron rotor housings was not sufficient to demonstrate the thermal performance of the coating systems as the coatings failed before adequate data could be obtained. A conclusion which can be drawn from the rotor housing testing is that successfully coating the aluminum rotor housing with an insulating material with good tribological properties may not be possible. The aluminum rotor housings tested on the Mazda engine failed in the zirconia layer probably from the combination of high compressive loads under the apex seals and high tensile loads caused by the high thermal expansion of the aluminum housing. The coating failure may have been aggravated by either a poor quality PSZ plasma spray or damage to the PSZ caused by the trochoid grinding process. Based on these results, the processing of the rotor housing for the $1007 R$ engine has been closely watched at every step to improve the quality of the resulting coating which will hopefully provide sufficient life to enable heat rejection data to be obtained.

8. Testing of the special coated cast iron Mazda rotor housings with minimal cooling (no cooling passages in the high heat flux area) were more successful, in that the coatings did not fail immediately (they were used for three engine builds). The engine ran very well with the cast iron housings and sounded different (less high frequency noise) 
at low power levels and experienced failures of the apex seal system which terminated each test as the power was increased. The apex seal system failures included severe bowing of the seals (indicating that the wear surface was running significantly higher temperature than the inner surface of the seal), accelerated apex seal wear and sticking of the seals in the rotors. These failures are due to breakdown of the lubrication system at the very high surface temperatures which were experienced on the inner surface of the insulated cast iron rotor housing. Based upon extrapolation of the rotor housing heat flux thermocouple data, the temperature of the cast iron and coating interface was in excess of $244 \mathrm{C}$. as compared to $103 \mathrm{C}$. for the baseline engine at the same load. The baseline engine had a wall temperature of 127 C. at full load. While the absolute values of these data are highly questionably (actual temperatures are known to be higher) the data does show that the minimally cooled, insulated cast iron housing runs significantly hotter than the standard cooled aluminum housing. This high temperature operation breaks down the lubricating oil causing an increase in friction and also forms hard deposits (which cause the apex seals to stick).

9. As discussed separately in the ADAPCO report the conclusion of the cycle analysis, thermal analysis and stress analysis are that the design approach to insulating the rotor is sound and has acceptable stress levels. However, it is predicted that the insulated aluminum rotor housing with water cooling and the uncooled, insulated, cast iron rotor housing both have excessively high stress levels and will fail. ADAPCO does point out that their analysis could be greatly improved with additional fundamental property data for the coating systems and by using a more sophisticated cycle analysis and transient thermal analysis.

10. Analysis of the cycle simulation data, with various degrees of heat rejection reduction, shows that for a 40 percent reduction of heat rejection to the coolant and lube that an additional 15 percent of the rated engine power is available in the exhaust for compounding recovery.

\section{Z.0 RECOMMENDATIONS}

This program has concluded that it is possible to reduce the heat rejection of high performance rotary engines by using state-of-the-art thermal barrier coatings provided that the basic engine components are made of compatible materials. In order to improve the engine for aircraft applications (or other applications which are weight sensitive) it is necessary to find an alternative to aluminum and cast iron for the engine housings and rotors. A material with low density and good high temperature strength is required. A study to identify an optimal material to replace aluminum or ductile iron for high temperature piston engines [3] has identified a titanium alloy (Ti6242) as having the desired properties and which also has low thermal conductivity.

It is recommended that a technology demonstrator engine be designed using the Ti6242 alloy with thermal barrier coatings on the side housings, rotors and (to a limited extent) the rotor housing. The design should prove that titanium is a superior material for a high performance aircraft engine and that the resulting engine will be inherently more reliable (as compared to an engine with aluminum housing castings). A techno-economic analysis should then be performed to determine the cost and marketing implications. 
It is recommended that efforts be continued (by NASA and others) to develop high temperature lubrication systems which are applicable to the apex seal. This effort should include high temperature liquid lubrication, dry lubrication systems and work on material compatibility.

\section{RECOMMENDATION FOR TESTING AT JOHN DEERE}

It is recommended that the components be tested together in one engine build to determine the performance implications in the stratified charge combustion engine. Testing should be done with an eye to obtaining as much data as possible before coating failure occurs. The coated rotor (which should survive any coating failure of the rotor housing or side housings) should then be tested by itself for durability and performance. If the rotor coating is damaged, Adiabatics, Inc. will recoat it for free. 
1 
APPENDIX A

ADIABATIC, INC.

STATEMENT OF WORK

A -1 
APPENDIX A

ADIABATIC, INC.

STATEMENT OF WORK

TABLE OF CONTENTS

Section

Title

Page

INTRODUCTION . . . . . . . . . . . . . . . . . . . A-3

Task I Engine Selection and Baseline Test. . . . . . . . A-3

Task II Thermal Analysis... . . . . . . . . . . . A-5

Task III Adiabatic Component Design . . . . . . . . . . A-6

Task IV High Temperature Apex/Side Seal Tribology. . . . . A-6

Task V Prototype Engine - Procurement/Assembly - Mazda 13B. . A-7

Task VI Engine Testing . . . . . . . . . . . . . A-7

Task VII Prototype engine - Procurement - NASA 1007R. . . . . A-8

Task VIII Exhaust Energy Utilization . . . . . . . . . . . A-8

Reporting Requirements . . . . . . . . . . . . . . A-8 


\section{ADIABATIC WANKEL TYPE ROTARY ENGINE \\ CONTRAC'I NAS3-24880}

\section{STATEMENT OF WORK}

\section{INTRODUCT ION}

The objective of this project is to design, fabricate, procure, assemble and test a prototype low heat rejection rotary engine based on studies performed in the SBIR Phase I cont.ract entitled "Adlabatic Wanke1 TYPE Rotary Engines" completed in 1985. A program consisting of elght (8) tasks was formulated to acconplish this project as follows:

I Engine Selection and Baseline Test

II Thermal Analysis

II Adiabatic Component Design

IV High Temperature Apex/Side Seal Tribology

$\mathrm{V}$ Prototype Engine - Procurement/Assembly - MAZUA 13B

VI Engine Testing

VII Prototype Engine - Procurement - NASA $1007 \mathrm{R}$

VIII Exhaust Energy Ut11iaation

The following 1s a narrative description of the work plan for each task.

\section{TASK I Englne Selection and Baseline l'est}

This first task starts with selection and purchase of a test engine followed by instrumentation of the engine and baseline testing. Per the conclusions of the first quarterly report and review at a meeting with Mr. William Hady al. NASA LeRC November 12, 1986 a Mazda 13B engine of the latest configuration was procured. Based on engine availability and suitability for test cell operation the engine was purchased (following approval from lir. William llady) Crom Riveinf Beat.,

$$
A-3
$$


Inc. of Anaheim California. The conflguration of the engtre 1s listed in the following table:

Mode 1

Displacement

Rated Power

Intake Port.s

Exhaust Ports

Exhaust Manifold

Carburetion

Ignition Distributor

Electronics)

Ignition Coils

Flywhee l
Mazda $13 \mathrm{~B}$

$1.308 \mathrm{~L}(80 \mathrm{Cu}$ In $)$

$132 \mathrm{KW}$ ( 177 Horsepower)

6 Side Ports (2 Valved)

2 Peripheral

Racing Type Header

Dellorto 48 DHLA (Dual sidedraft)

Mazda Breakerless

(Integral

Mazda Transistor Ignition 'lype Lightwelght steel Type

The plan is to use this englue for oomponent goreening (meohandcal screenting as opposed to performance development). The logic behind this approgoh is that the addition of low heat rejection components to a homogeneous oharge engine will ralse the temperature of the gases during the compresglon stroke and lucrease the tendency of the angline to detongte (early combustion). To counteract this phenomena special fuels with very high octane numbers will have to be used along with power reductions. A test plan for the engine is to be prepared which includes engine and test cell instrumentation, assembly instructions, test cell listallation detalls and the actual 11sting of tests to be run. An eddy ourrent type dyno matched to the Mazda engine is bejing used for this project.

Because the selected engine is a inature product the initial testing is limited to refinement of the test facility and baseline performance measurements of the engine with no endurance or durability testing. A partial listing of the parameters which are be measured and the measuring method are
as follows: 
Englne Speed

lorque

Euel Flow

Air Flow

Intake Temperature

Exhaust Temperature

Coolant In Temperature

Coolant out Temperature

011 In Temperature

o1l Out. Temperature

Rotor Housing Temperature

Side Housing Temperature

Coolant Pressure

011 Pressure

Barometric Pressure

Wet and Dry Bulb Amb Temps.
Speed plokup on dyno.

Load Cell on dyno.

Mass Type Flowmeter

Mass Type Elowineter

Thermocouple

Thermocouple

Thermocouple

Thermocouple

Thermocouple

Thermocouple

Thermooouple

Therinocouple

Bourdon tube gage

Bourdon tube gage

Mercury Barometer

Sling Psychrometer

Following recelpt of the inputs from NASA the detailed test plan will be flnallzed and subintted to NASA for approval.

Following approval of the test plan the Contractor w111 conduct the test program and prepare and lssue an informal test report.

Task II Thermal Analygis

A thernal analysis shall be conducted for NASA's 1007R engine to obtain a thermal history tnoluding the temperature distribution in the rotor and rotor houstugs during rated and peak torque operating conditions.

The analysis shall provide the basis for caloulating the distortion, allowable clearances and thermal stresses in these components. The therinal stresses obtained in this analysis shall be combined with the rotating stresses and pressure loading stresses to provide input for the component design to be performed in Task III - Adlabatic Component Jesign.

After completion of the thermal analysis, the lonlractor shall prepare an informal report and present. it, to the NA:SA Project

$$
\text { A- } 5
$$


Manager for his approval. Upon approval, the Contractor shall proceed with the design of all the adlabatic components as determined in Task III - Adiabatic Component Design.

The following inethod will be used to accomplish thls task:

a. NASA to furnish 1007R drawings and test data to ADAPCO.

b. NASA to furnish MIT Stratifled Charge Combustion lodel.

c. ADAPCO w111 incorporate $1007 \mathrm{R}$ geometry and run the MIT model to generate boundary conditions.

d. ADAPCO to use John Deere data to verify model.

e. ADAPCO to generate $\mathrm{EE}$ model of $1007 \mathrm{R}$ rotor and rotor hsg.

f. ADAPCO to use boundary conditions from $c$. and run $\mathrm{FE}$ analysis.

g. ADAPCO to prepare informal report.

\section{Adlabatic Component Design}

Following completion of TASK 2 , the Contractor will upon approval from NASA's Project Manager have ADAPCo proceed to modify the models for combustion and the FE models for the rotor and rotor housing to include selected low heat rejection components and to run the models and analysis at the low heat rejection conditions. These results will be uaed in an iterative manner to design the actual modifications to the 1007R parts. Detalled drawings of the modifications will be completed by Contractor personnel and submitted to the Project Engineer for approval. Upon appoval, the contractor may initiate procurement of the adjabatio components out.lined in task IV - Hlgh Temperature Apex/Side Seal. Trlbology and task VI - Prototype Engine Procurement - NASA 1007R.

\section{High l'emperature Apex/Side Seal I'ribology}

The Contractor shall evaluate and procure candidate apex seals, side seals and high temperature lubricants as follows:

Based on expertence from reciproogting adlabatic engine testing four candidate sets each of apex seals aud side seals A -6 
for high temperature operation along with high temperature oil for two oll changes will be procured for the 1007R engine. The same candidate apex seal and side seal designs will be procured for the Mazda engine along with the same high temperature oil. The apex seals and high temperature oil will be run in the Mazda engine build with the low heat rejection rotor housing and the side seals and high temperature lube will be run in the engine build with the low heat rejection side housings.

Y Prototype Engine - Procurement/Assembly - Mazda $13 \mathrm{~B}$

The Contractor shall procure, fabricate, modify, and agaemble a complete prototype adiabatic rotary englie lutilizing those parts and or components obtained in performance of Tasks I, III and IV. This engine $1 \mathrm{~s}$ to be uged for screentug components for later inclusion in the $1007 \mathrm{R}$ engine. A series of screening tests are to be planned wherein a concept can be tested individually for mechanical and trlbological integrity.

\section{YI Engine Testing}

The Contractor shall install the Mazda $13 \mathrm{~B}$ rotary engine and auxiliary components from Task IV (High lemperature Apex/Side Seal Tribology) to his test facility and make all necessary preparations for testing. Prior to cominencing the engine testling a test plan w1ll be prepared and approved by the NASA Project Manager. The engine testing shall consist of separate engine bullds and tests for the rotor, rotor housing, and side housings along with a final test of the complete engine. A minimum of four separate engine bulld and test oyoles are required. 
VII Prototype EngIne - Procurement - NASA 1007R

The Contractor is to provide thermal barrier coatings for the following parts of the NASA $1007 \mathrm{R}$ engine:

Note: The parts to be coated are NASA owned parts which are presently at John Deere.

ROTOR - The 1007R rotor will be machined and coated the same as the Mazda rotor.

SIDE HOUSINGS - The present 1007R side housings are aluminum and present the same problem as the aluminum rotor housings. Depending upon the results from the Mazda testing and the thermal analysis program, elther zirconia coated aluminum housings with the three cycle coating or plasma sprayed chrome-oxide or the K-Ramic coated cast fron housings will be supplied.

ROTOR HOUSING - The selection of rotor housing material and coating will be dependant upon the results of the Masda testing and the thermal analyais.

The testing of the $1007 \mathrm{R}$ components w111 be gcoomplished by John Deere and is not included in this project.

\section{YIII Exhaust Energy Ut1lization}

The Contractor shall conduct a study on methods of recovering waste energy from the exhaust of the adlabatic rotary engine using exhaust gas data from the $1007 \mathrm{R}$ engine and the results of the thermodynamic modeling of that engine with low heat refection components. The results of this study will be presented to the NASA Project Manager for his approval.

\section{Reporting Requirements}

Reporting shall be in accordance with the Feports of Work attachment except as modified below:

1. A Quarterly Technical and Progress Report, shall be substituted in lieu of the Monthly Report.

$$
\text { A-8 }
$$


2. Each tagk shall be reported in the Guarterly Progress Report.

3. The Quarterly Progress Report shall include the number of labor hours expended for each category of labor for the quarter as well as cumulative totals.

4. One (1) copy of the Einal Report draft shall be submitted for review in lieu of the four (4) copies specified. 
APPENDIX B

ENGINE TEST PLAN

B-1 
The engine test plan encompasses five engine configuration tests: the standard engine. the standard engine with coated rotors, the standard engine with coated intermediate housing. the standard engine with coated rotor housings, and the standard engine with a combination of all above mentioned costed components. The purpose of the engine tests is to screen components for later inclusion on the 1007R engine. The data from the testing will be analyzed to determine the change in heat rejection.

The first test configuration. the standard engine, is being run to develop baseline information. Because the selected engine is ature product the initial testing is limited to refinement of the test facility and performance measurements of the engine with no endurance or durability testing.

The test consists of engine preparation, instrumentation, and machining of the engine rotor housings and intermediate housing to ensble installation of thermocouples. The assembled engine will be placed on the test stand and connected to an Eaton eddy current type dynamometer Model AD-8081.

The following parameters will be measured and recordeds

Engine Speed

Torque

Fuel Flow

Intake Temperature

Exhaust Temperature

Coolant In Temperature

Coolant Out Temperature

oil In Temperature

oil Out Temperature

Rotor Housing Temperature

Side Housing Temperature
Speed pickup on dyno. Load cell on dyno.

Mass type flow meter.

Thermocouple

-

$\infty$

$\infty$

$\infty$

$\cdots$

$\bullet$

$\infty$

B-2 


$\begin{array}{ll}\text { Intake Pressure } & \text { Mercury Manometer } \\ \text { Exhaust Pressure } & \text { Mercury Manometer } \\ \text { Blow by } & \text { Mercury Manometer } \\ \text { Coolant Pressure } & \text { Bourdon Tube Gauge } \\ \text { Oil Pressure } & \text { Bourdon Tube Gauge } \\ \text { Barometric Pressure } & \text { Mercury Barometer } \\ \text { Wet \& Dry Bulb Amb. Temps. Sling Psychrometer }\end{array}$

(For locations of rotor housing and intermediate housing thermocouples see Figures $1 \& 2$.)

Periodic visual inspection through the exhaust ports and pre and post test measurements of the wear ourfaces will be performed.

The second engine configuration to be tested is the baseline engine with the addition of two insulated rotors. The two rotors will be coated with plasma sprayed zirconia and then densified with a chrome oxide coating. This test will include an endurance teat at various loads to ensure proper component screening. The same parameters will be measured as outlined in the first test configuration.

The third engine configuration tested is the baseline engine with a coated intermediate housing and coated side seal. This test will also be performed under endurance conditions and the test will measure the same parameters as above.

The fourth engine configuration tested is the baseline engine with coated rotor housings and coated apex seals. Testing will be done in the ame manner a above.

The last engine configuration tested is with a combination of all costed components. This test will be performed if all components endure the previous tests. The same parameters will be measured.

Once the test program is performed, Adiabatics. Inc. will prepare and issue an informs 1 test report. 

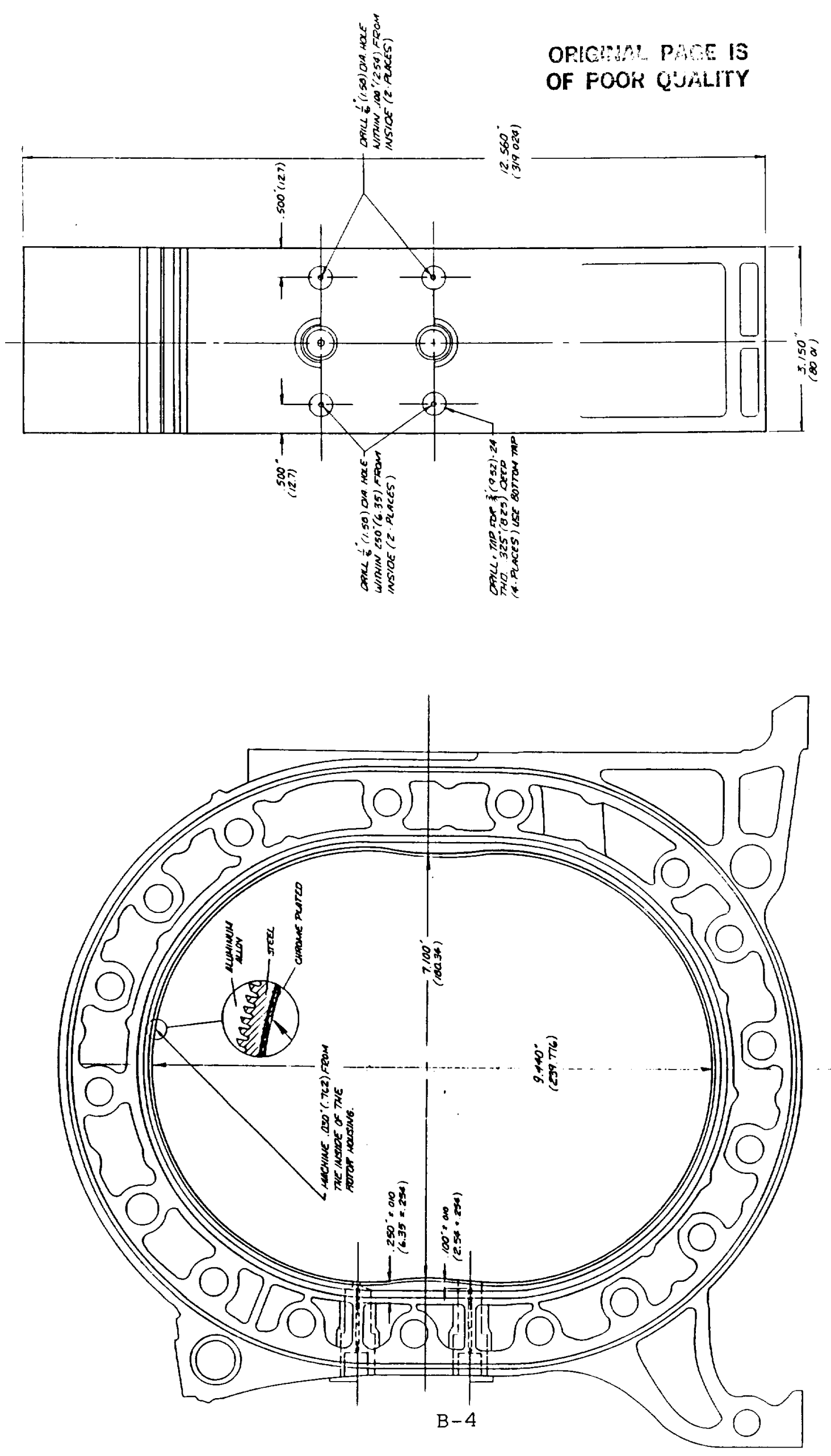

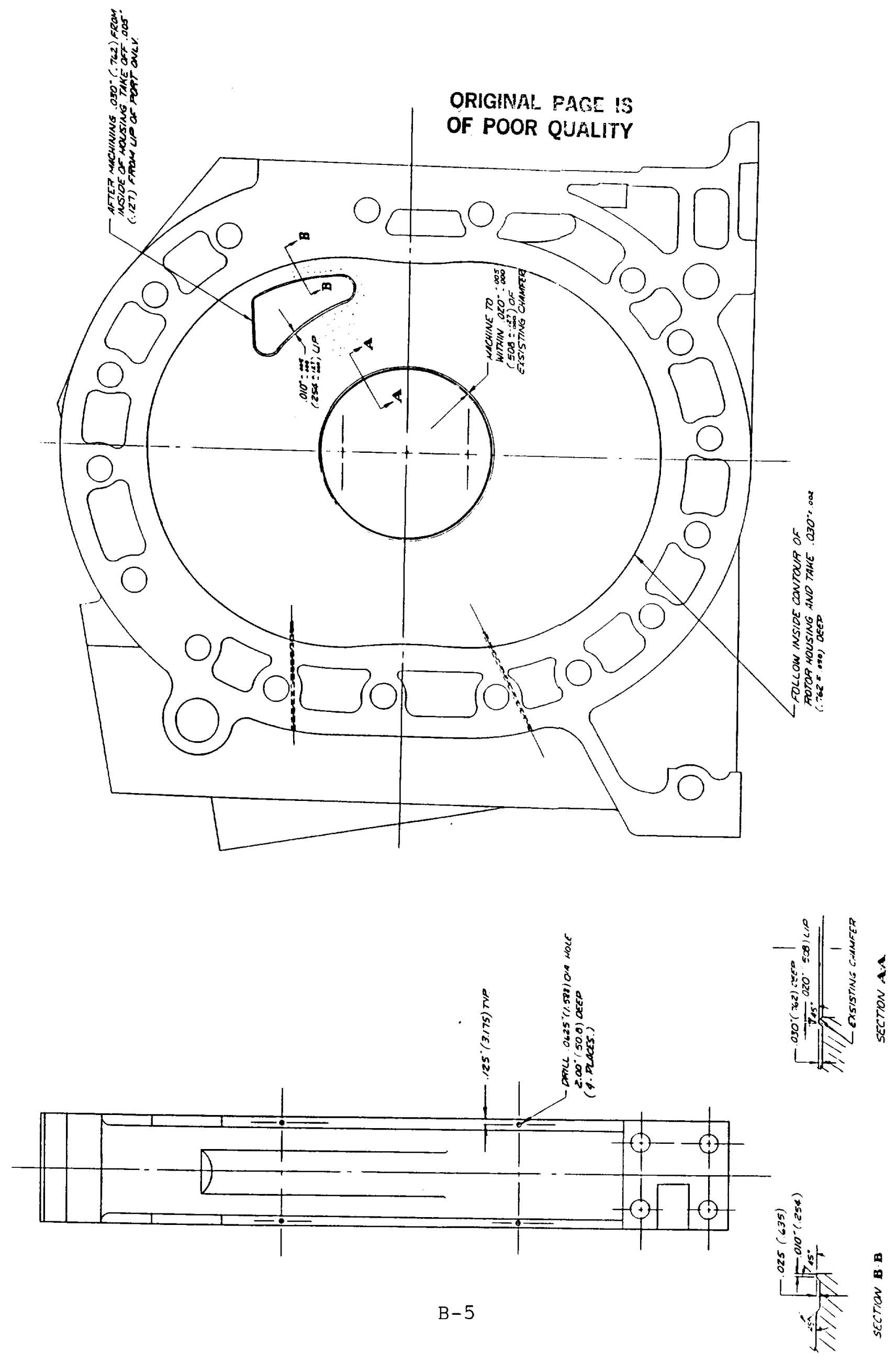
APPENDIX C

BASELINE DATA

C -1 
BASELINE DATA

TABLE OF CONTENTS

Title

Page

\begin{abstract}
Baseline Chart . . . . . . . . . . . . . . . . . . . . . C-3
Baseline Chart . . . . . . . . . . . . . . . . . . . . . . .

Baseline Chart . . . . . . . . . . . . . . . . . . . C-5

Baseline Data. . . . . . . . . . . . . . . . . . . . . C-6

Baseline Data. . . . . . . . . . . . . . . . . . . . C-6
\end{abstract}




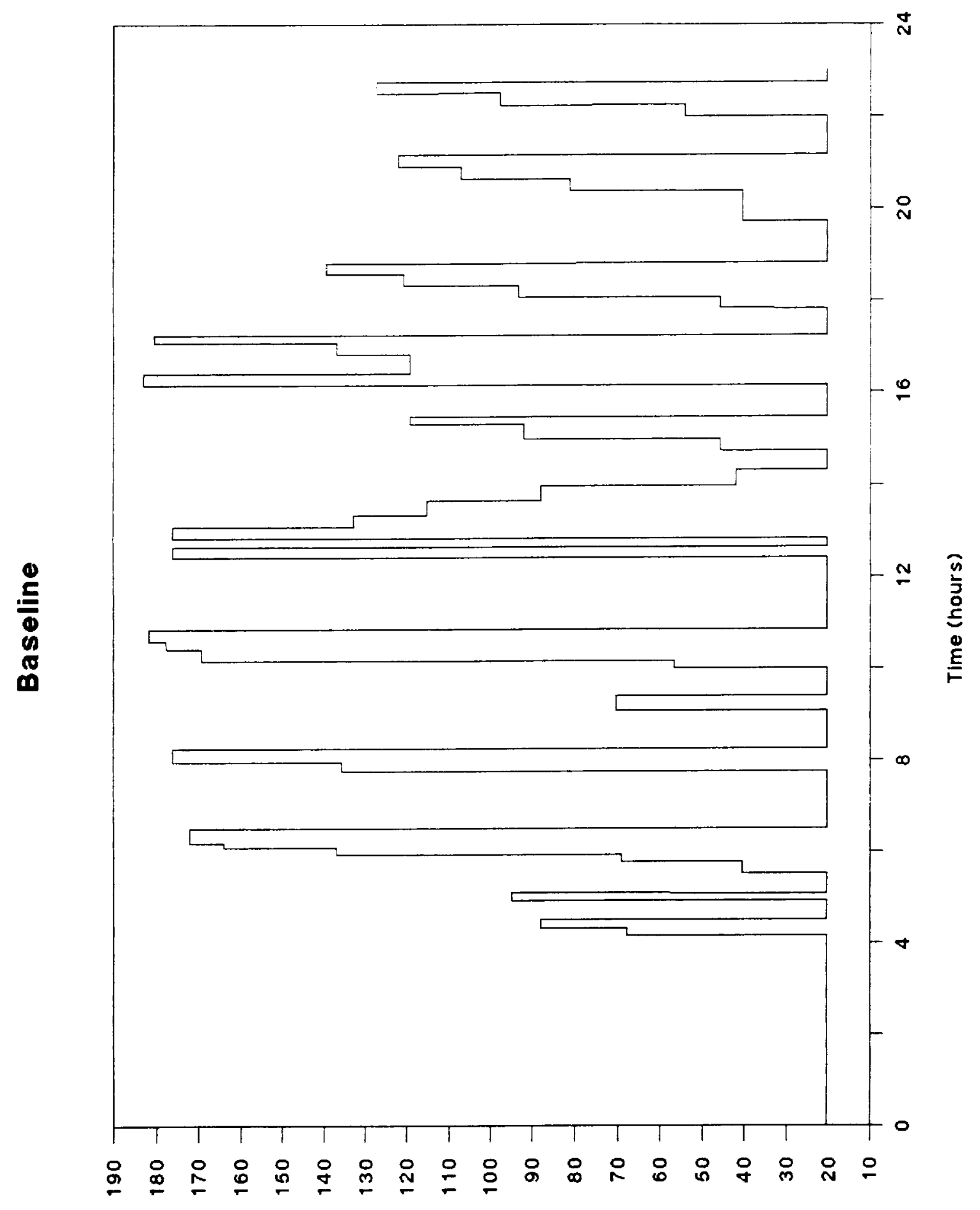

$\left(w_{* N}\right)$ enbsol

$$
\text { C }-3
$$




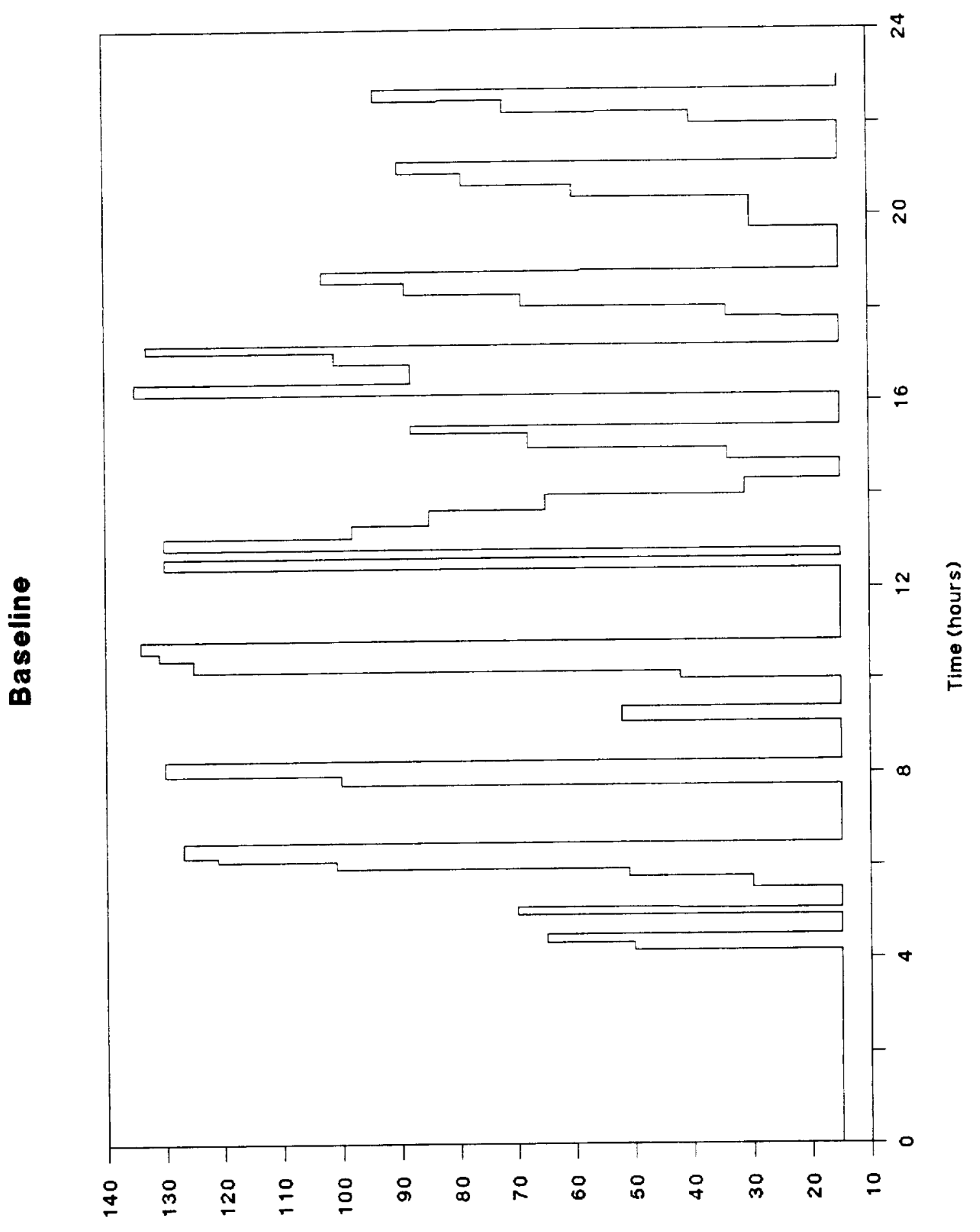

(tf*sql) enb.

C -4 


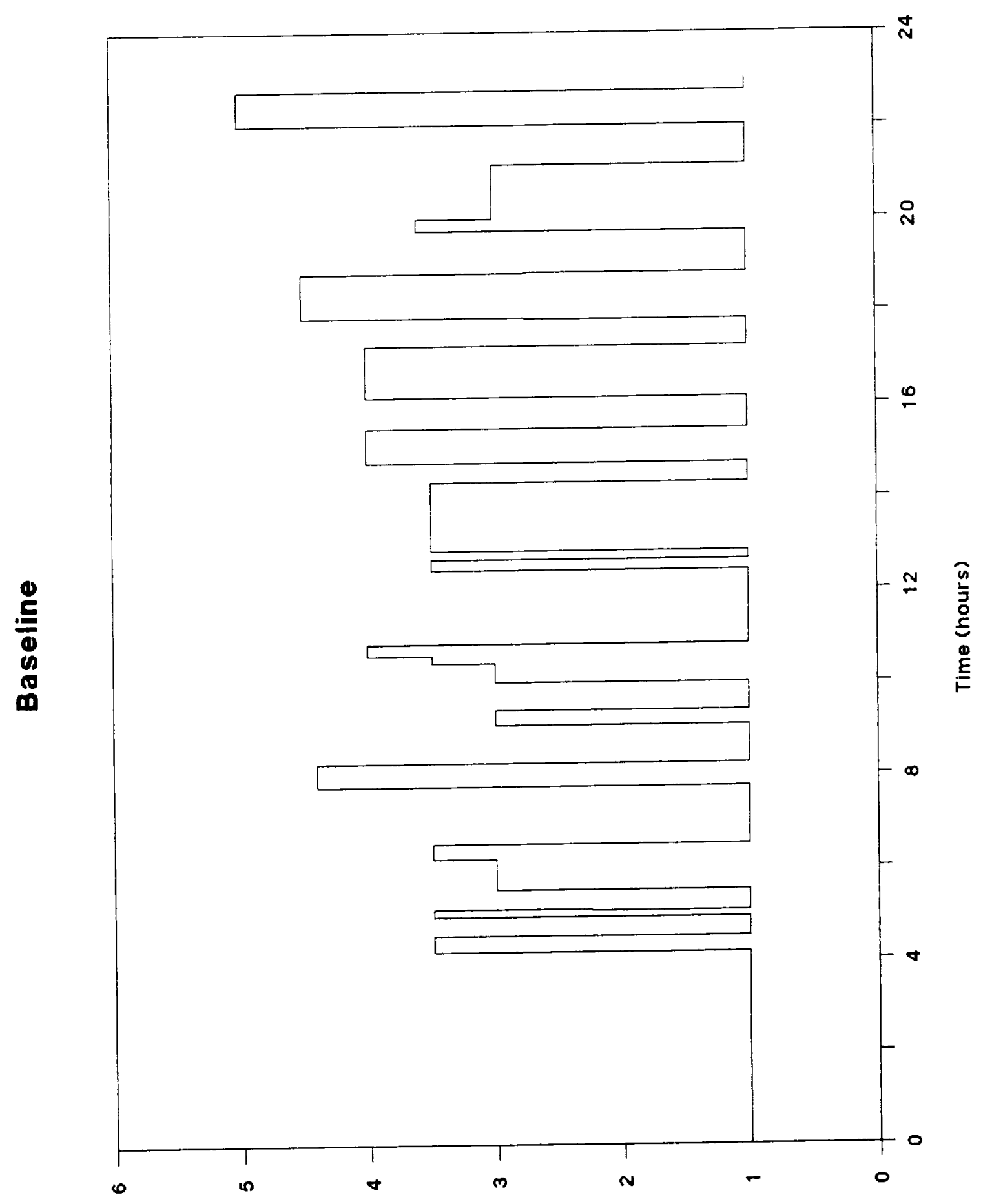

(spuesnoul)

(udd) peads

$$
c-5
$$




\begin{tabular}{|c|c|c|c|c|c|}
\hline$\underline{\underline{E}}$ & 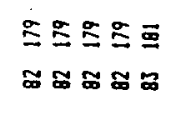 & 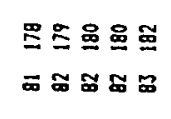 & 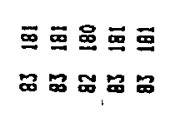 & 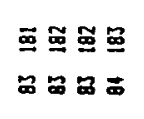 & \\
\hline & 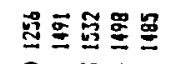 & 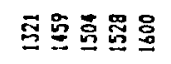 & 暍影路总 & 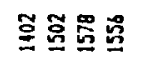 & \\
\hline & 崽う & 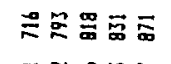 & 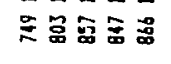 & 方合品引 & \\
\hline & & $=\approx s \approx n$ & $=35 \approx 8$ & $\because 328$ & \\
\hline 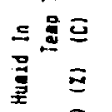 & 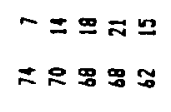 & 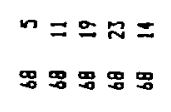 & 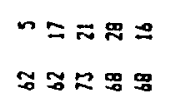 & 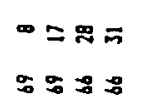 & \\
\hline & 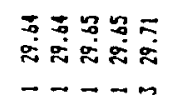 & 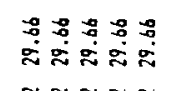 & 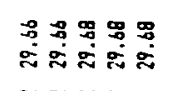 & 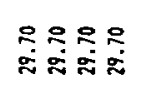 & \\
\hline & 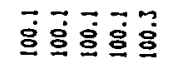 & 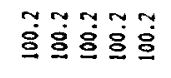 & 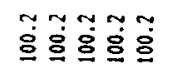 & 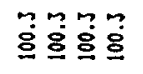 & \\
\hline & 䍐 $\mathbf{8} 5: 98$ & 용요 & 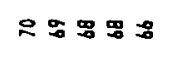 & 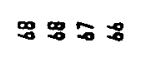 & \\
\hline & $5 \div 9$ & 里鸟品 & 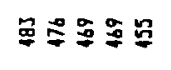 & 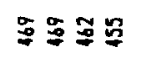 & \\
\hline & $\simeq \simeq \simeq \simeq \simeq$ & $n= \pm m=$ & ஹㅗี & $N \approx N \approx$ & \\
\hline & 30 & $\underline{9}$ & $\Xi \Xi 99$ & $\Xi \Xi \Xi \Xi$ & \\
\hline & 00 & $\infty$ & 00000 & 0000 & \\
\hline & - & 00000 & 00000 & 0000 & \\
\hline & 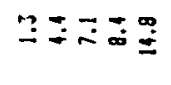 & 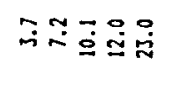 & 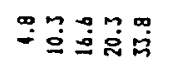 & 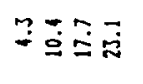 & $\ddot{~} \stackrel{\circ}{=}$ \\
\hline & 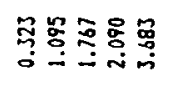 & 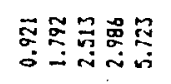 & 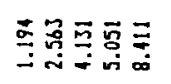 & 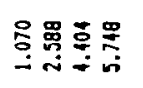 & $\underset{9}{\stackrel{9}{9}}$ \\
\hline & 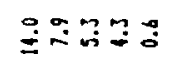 & 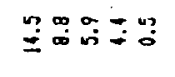 & 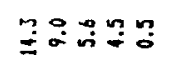 & 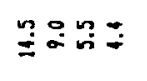 & \\
\hline & $\stackrel{2}{s} \stackrel{0}{=} \stackrel{0}{=}$ & g。ّ & 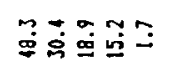 & 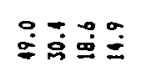 & \\
\hline & 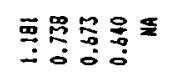 & 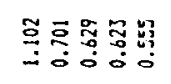 & 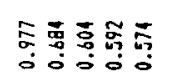 & 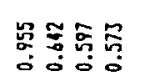 & \\
\hline & 器事总总 & 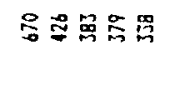 & 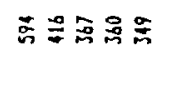 & 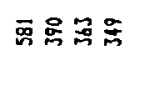 & \\
\hline & 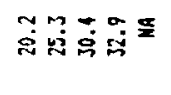 & 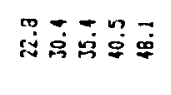 & 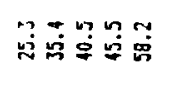 & 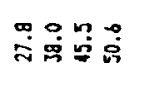 & \\
\hline & 受金富高 & 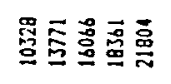 & 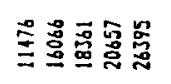 & 芯吾突总 & 言总 \\
\hline & $\infty \simeq \simeq \simeq$ & $a \simeq=20$ & 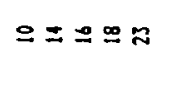 & $=\simeq \mathbf{m} \mathbf{a}$ & \\
\hline & 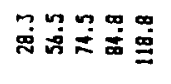 & 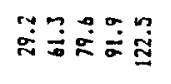 & 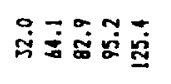 & 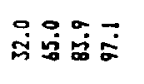 & $=0$ \\
\hline & 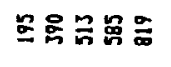 & 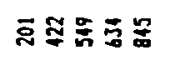 & 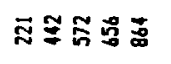 & 西罗哭品 & \\
\hline 2 & 产富宫是 & 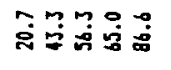 & 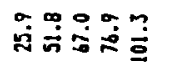 & 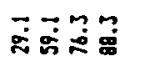 & 象品 \\
\hline & 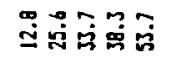 & $\overrightarrow{\mathrm{g}}$ & 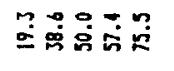 & 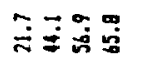 & $\overrightarrow{\dot{g}} \overline{-}$ \\
\hline $\bar{E}$ & 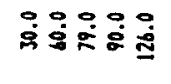 & 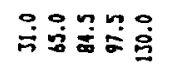 & 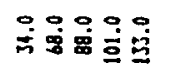 & 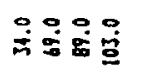 & 审ं \\
\hline$=$ & 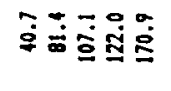 & 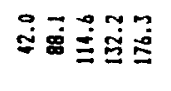 & 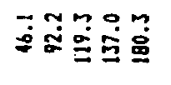 & 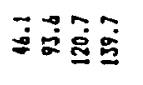 & 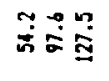 \\
\hline & 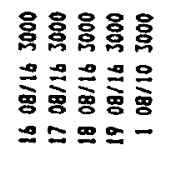 & 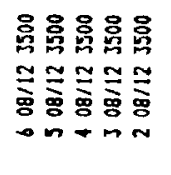 & 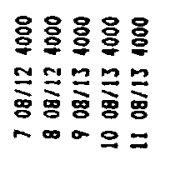 & 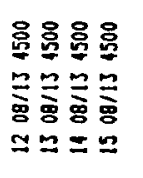 & 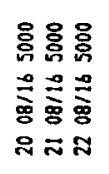 \\
\hline
\end{tabular}




\begin{tabular}{|c|c|c|c|c|c|}
\hline 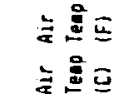 & 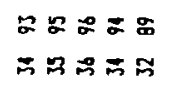 & $\begin{array}{l}=28=2 \\
=\approx 00\end{array}$ & 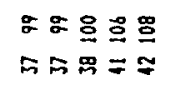 & $\begin{array}{l}8 \\
8 \\
0:\end{array}$ & \\
\hline$m$ & 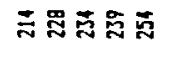 & 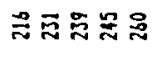 & $\bar{N}$ & $\Xi \Xi \bar{\Xi}$ & $\approx \Xi$ \\
\hline$=$ & $\bar{\Xi} \Xi \Xi \Xi \Xi$ & $\cong \Xi$ & $\Phi \Phi$ & & $\Xi \Xi$ \\
\hline : & 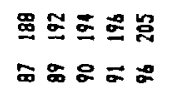 & 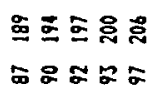 & $\begin{array}{l}\Xi \Xi \\
\Phi \approx\end{array}$ & $\begin{array}{l}\tilde{a} \\
\alpha\end{array}$ & 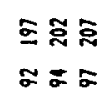 \\
\hline & $\approx \approx$ & 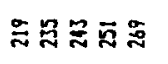 & $\bar{\pi} \bar{\approx}$ & 玉 & N \\
\hline & $\ddot{\varrho} \cong \cong 9 \mathbb{\Xi}$ & $\underline{\underline{\Xi}} \cong \mathbb{\Xi} \tilde{\underline{Z}}$ & $\underline{\underline{9}}$ & $\cong \Xi$ & $\bar{I}$ \\
\hline & & & & & $\bar{\Sigma}$ \\
\hline |: & & & & & \\
\hline$=$ & $\approx \approx$ & $\vec{F}$ & $\vec{n}$ & 홍요 & 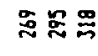 \\
\hline & $\Xi \Xi \Xi \Xi \tilde{I}$ & $\Xi \Xi$ & & & $=$ \\
\hline & 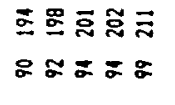 & $\begin{array}{l}\stackrel{2}{2} \\
\vdots \Xi\end{array}$ & & 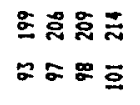 & \\
\hline & 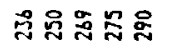 & 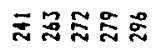 & 유: & & 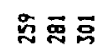 \\
\hline & 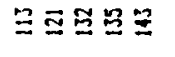 & 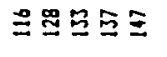 & & & 果 \\
\hline & & & & & \\
\hline & $\approx$ & 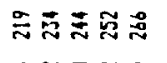 & $\stackrel{2}{\approx}$ & & 串蛋 \\
\hline & $\stackrel{g}{\Xi} \cong \Xi \Xi$ & 号罪 요 & $\Xi 2$ & 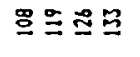 & 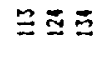 \\
\hline & 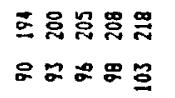 & 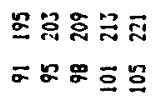 & 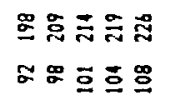 & 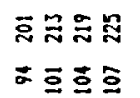 & $\begin{array}{l}\mathbf{D} \approx \approx \\
\mathbf{D} \Xi \mathbf{g}\end{array}$ \\
\hline & 풍요 & 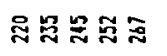 & $\approx \approx$ & 急尽 & 点踪 \\
\hline & 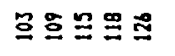 & $\Xi \cong \cong \Xi \Xi$ & 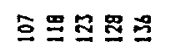 & $\Phi \bar{\Xi} \Xi \underline{\Xi}$ & $\Xi \Xi$ \\
\hline & 8 & $\bar{\approx} \stackrel{\sigma}{\approx}$ & $\Xi$ & & 政 \\
\hline & 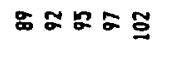 & のよ゙ます & $\approx=$ & 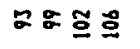 & $2 \Xi$ \\
\hline$\dot{\mathbf{z}} \mathbf{z}$ & $\because=$ & $==$ & $= \pm$ & $\Rightarrow \approx D=$ & 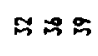 \\
\hline & $\simeq$ & & & & \\
\hline & $\Xi \Xi \Xi \Xi す$ & $\Xi \Xi \Xi \Xi \Xi$ & $\Phi \Xi$ & & ฉำฐ \\
\hline ت & 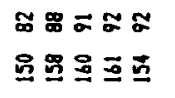 & 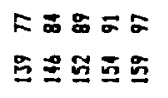 & $\begin{array}{l}2=0 \\
\equiv\end{array}$ & 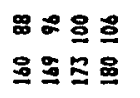 & 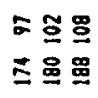 \\
\hline & $: 2 \approx \approx 00$ & $5358=$ & :Rロニ゚ & Е 天゚思 & $\approx \approx:$ \\
\hline & $\underline{\mathbf{g}} \mathbf{\Xi} \mathbf{\Xi} \mathbf{\Phi} \mathbf{\Xi}$ & $\underline{\Phi} \mathbf{\Phi} \mathbf{\Phi} \mathbf{\Phi} \mathbf{\Phi}$ & 畐菩芯台兽 & 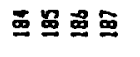 & $\mathbf{\Xi} \mathbf{\Xi}$ \\
\hline & & あらすのる & 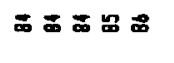 & 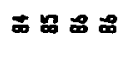 & 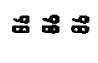 \\
\hline 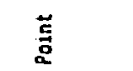 & 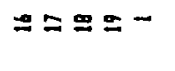 & $a n+m$ & $\cdots \infty=$ & $\simeq m=$ & $\pi$ \\
\hline
\end{tabular}


APPENDIX D

ADAPCO

STATEMENT OF WORK

$D-1$ 
STATEMENT OF WORK

The purpose of this program is to determine the structural implications of an "adiabatic" direct injection stratified charge combustion rotary (Wankel) type engine.

To accomplish this program ADAPCO is to perform the following tasks using the NASA (John Deere) 1007R engine as the candidate engine:

1. Generate the three dimensional ANSYS finite element model for the rotor and rotor housing using the drawings generated by John Deere.

2. Using the MIT DISC model, generate the thermal and pressure boundary conditions for the above engine at rated and torque peak conditions.

3. Compare the results of the above analysis with test data supplied by John Deere and iterate the model as necessary such that the predicted pressures and temperatures agree with the measurements.

4. Using the above boundary conditions along with inertia loads and assembly loads, run the FE models and determine the deflections, stresses and temperatures of the components.

5. Run the MIT DISC model for the adiabatic configuration assuming a .030 inch plasma sprayed zirconia thermal barrier coating densified from chrome oxide on the combustion face of the rotor, the side housings and the rotor housing to determine the pressure and temperature boundary conditions for the insulated engine.

6. Modify the FE models to include the thermal barrier coatings.

7. Run the FE models with and without coolant in the rotor housing. Reiterate back through task 5 as necessary such that the MIT DISC and ANSYS surface temperatures are in agreement.

8. Analyze the results of the above run to determine if the stresses, temperature and deflections are acceptable. If they are not acceptable, modify the models to incorporate design changes to make the values acceptable and recycle until a satisfactory solution is found.

\section{REPORTING}

An interim report and a final report which details all of the effort and results shall be prepared and submitted per the schedule. A magnetic tape copy of the completed ANSYS finite element models is required.

\section{SCHEDULE}

Program start date - 1 April 1987

Interim report due - 1 July 1987

Program complete - 1 October 1987

Final report due - 1 November 1987 
APPENDIX E

PRE \& POST MEASUREMENT

$E-1$ 
PRE \& POST MEASUREMENT

TABLE OF CONTENTS

Title

Page

Main Bearing . . . . . . . . . . . . . . . . . . . . . . . E-4

Rotor Housing. . . . . . . . . . . . . . . . . . . . . . . E E-4

Rotor. . . . . . . . . . . . . . . . . . . . . . . E-5

Rotor oil Seal . . . . . . . . . . . . . . . . . . . E-6

Apex Seal. . . . . . . . . . . . . . . . . . . . . . . . . . E-6

Side Seal. . . . . . . . . . . . . . . . . . . . . . . . E-7

Corner seal. . . . . . . . . . . . . . . . . . . . . . E-8

Pre \& Post Compression Tests . . . . . . . . . . . . . . . . E-9

Front Main Bearing Clearance . . . . . . . . . . . . . . . E-11

Rear Main Bearing Clearance. . . . . . . . . . . . . . . E-12

Front Rotor Bearing clearance. . . . . . . . . . . . . . . . E-13

Rear Rotor Bearing clearance . . . . . . . . . . . . . . . E-14

Front Rotor.Housing Width Difference . . . . . . . . . . . . E-15

Rear Rotor Housing Width Difference. . . . . . . . . . . . . E-17

Front Rotor Clearance. . . . . . . . . . . . . . . . . E-19

Rear Rotor Clearance . . . . . . . . . . . . . . . . . E-20

Front Rotor Oil Seal Lip Width . . . . . . . . . . . . . . E-2l

Rear Rotor oil seal Lip Width. . . . . . . . . . . . . . . E-23

Front Rotor Apex Seal Clearance. . . . . . . . . . . . . . . E-25

Front Rotor Apex Seal Height . . . . . . . . . . . . . . . E-26

Front Rotor Apex Spring Free Height. . . . . . . . . . . . . . E-27

Front Rotor Apex Seal Weight . . . . . . . . . . . . . . . E-28

Rear Rotor Apex Seal Clearance . . . . . . . . . . . . . . . E-29 


\section{TABLE OF CONTENTS (Cont.)}

\section{$\underline{\text { Title }}$}

Rear Rotor Apex Seal Height. . . . . . . . . . . . E-30

Rear Rotor Apex Spring Free Height . . . . . . . . . . . E-31

Rear Rotor Apex Seal Weight. . . . . . . . . . . . E-32

Front Rotor Side Seal Protrusion . . . . . . . . . . . E-33

Front Rotor Side Seal Weight . . . . . . . . . . . E E-35

Rear Rotor Side Seal Protrusion.............. . E-37

Rear Rotor Side Seal Weight. . . . . . . . . . . . . E-39

Front Rotor Corner Seal Protrusion . . . . . . . . . . . E-41

Front Rotor Corner Seal Weight ................ . E-44

Rear Rotor Corner Seal Protrusion. . . . . . . . . . . . E-46

Rear Rotor Corner Seal Weight. . . . . . . . . . . . . . E-49 
The five pages that follow are a description of the pre and post test measurement procedures. The procedures are described in the 1987 Mazda shop manual. All measurements not recorded were checked and were OK.

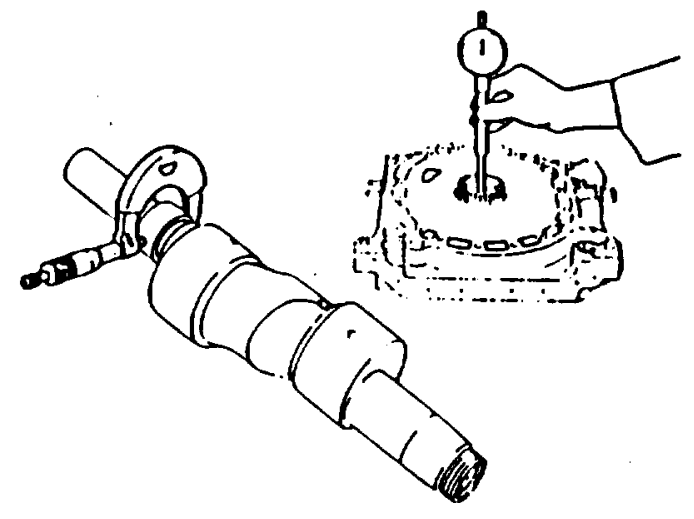

1. Check the main bearing clearance. Measure the inner diameter of the main bearing and the outer diameter of the eccentric shaft main journal.

$$
\begin{array}{ll}
\text { Standard clearance: } & 0.04-0.08 \mathrm{~mm} \\
& (.0016-.0031 \mathrm{in}) \\
\text { Clearance Limit: } & 0.10 \mathrm{~mm} \\
& (.0039 \mathrm{in.})
\end{array}
$$

ROTOR HOUSING

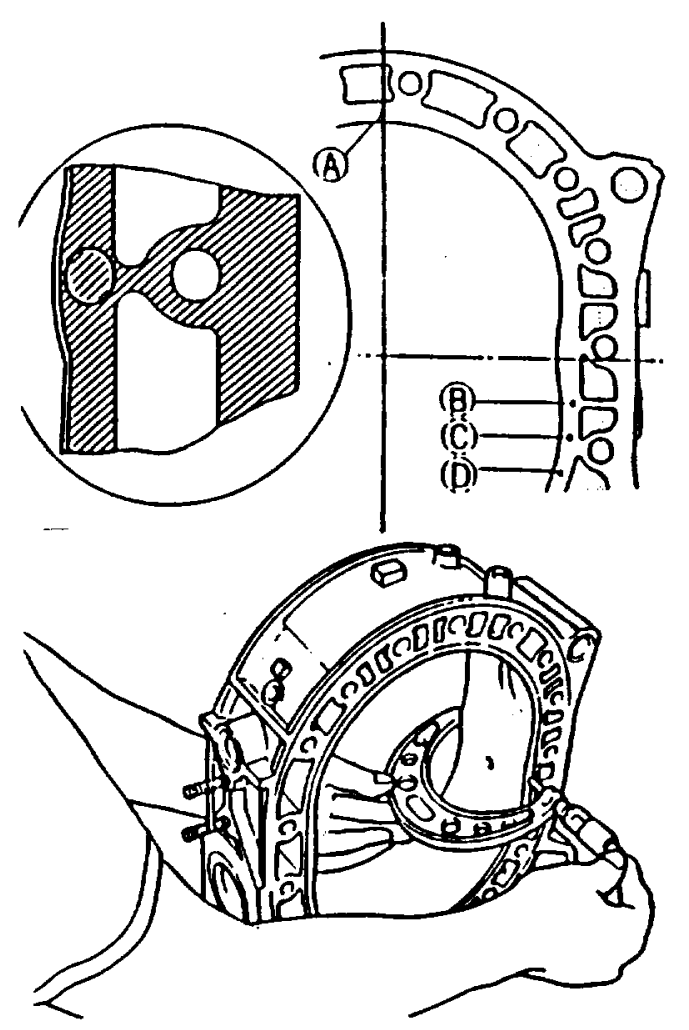

1. Check the width difference of the rotor housing. Measure the rotor housing width at the points $A, B, C$, and $D$ as shown in the figure.

2. Check the difference between the value of point $A$ and the minimum value among the points $B, C$, and $D$.
Difference Limit:

$$
\begin{aligned}
& 0.06 \mathrm{~mm} \\
& (.0024 \mathrm{in.})
\end{aligned}
$$


ORIGINAL P:OS Is

OF POOF Qusniri
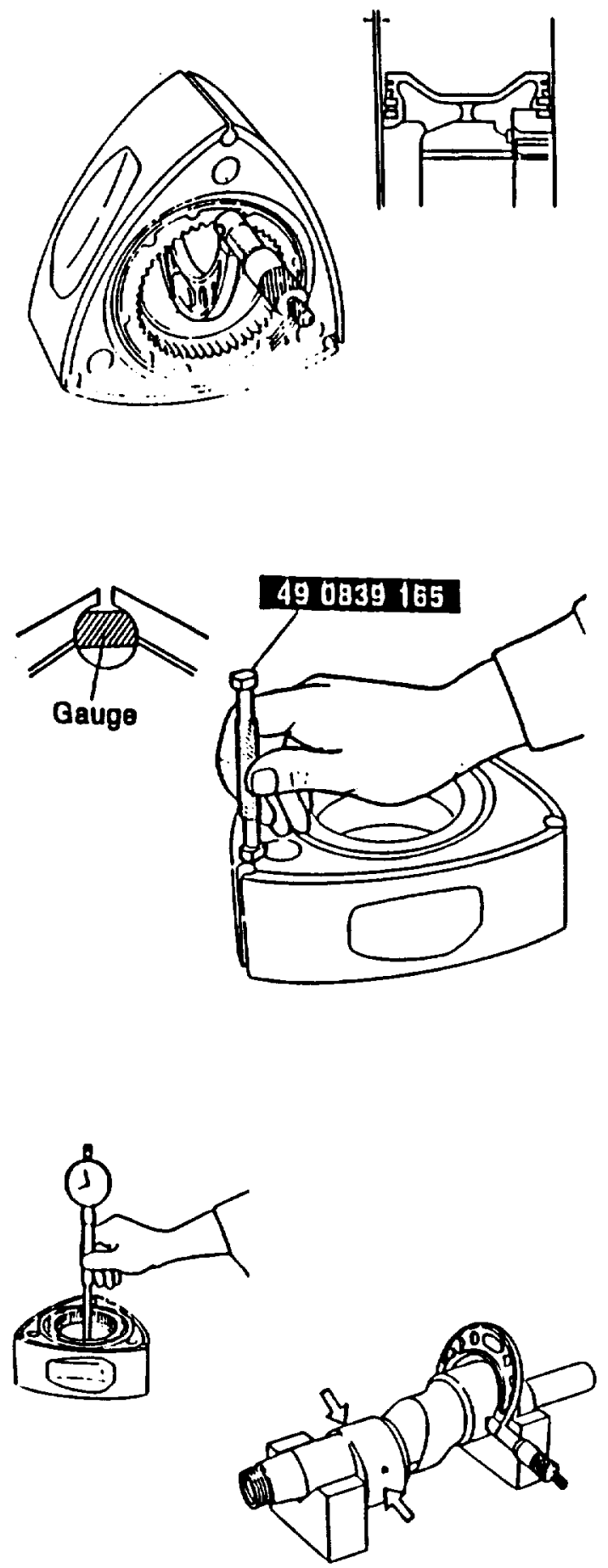

ROTOR

Check the clearance between the side housing and rotor.

1. Measure the rotor housing width and the maximum rotor width at three points.

$$
\begin{array}{ll}
\text { Standard Clearance: } & 0.12-0.21 \mathrm{~mm} \\
& (.0047-.0083 \mathrm{in.}) \\
\text { Clearance Limit: } & .004 \mathrm{in} .
\end{array}
$$

2. Check the corner seal bores for wear

1) If neither end of the gauge goes into the bore, use the original corner seal.

2) If only one end of the gauge goes into the bore, replace the corner seal.

3) If both ends of the gauge go into the bore, replace the rotor.

3. Check the rotor bearing clearance. Measure the inner diameter of the rotor bearing and the outer diameter of the eccentric shaft rotor journal. Standard

Clearance: $\quad 0.04-0.08 \mathrm{~mm}$

$$
(.0016-.0031 \text { in. })
$$

Clearance Limit: $0.10 \mathrm{~mm}$

$$
\text { (.0039 in.) }
$$


ROTOR OIL SEAL

1. Check the oil seal lip width.

$$
\text { Lipwidth: } \begin{aligned}
.0 .05 \mathrm{~mm} \\
(.020 \text { in } \max .)
\end{aligned}
$$
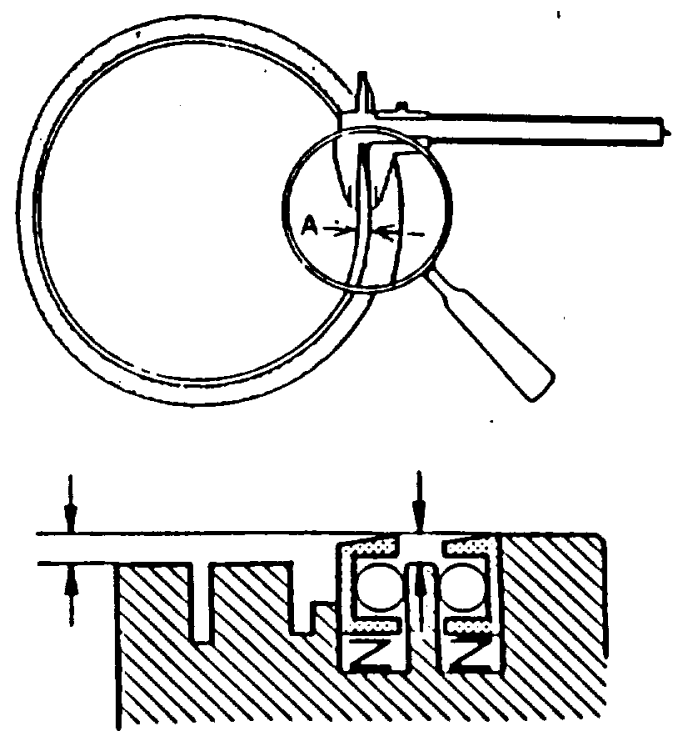

2. Check oil seal protrusion.

$$
\text { Protrusion: } \begin{aligned}
& 0.05 \mathrm{~mm} \\
& (.020 \mathrm{in} \mathrm{min.)}
\end{aligned}
$$

\section{APEX SEAL}

1. Measure the height of the apex seal at two points.

$$
\begin{array}{ll}
\text { Standard Height: } & 8.0 \mathrm{~mm} \\
& (.315 \mathrm{in.}) \\
\text { Height Limit: } & 6.5 \mathrm{~mm} \\
& (.256 \mathrm{in.})
\end{array}
$$
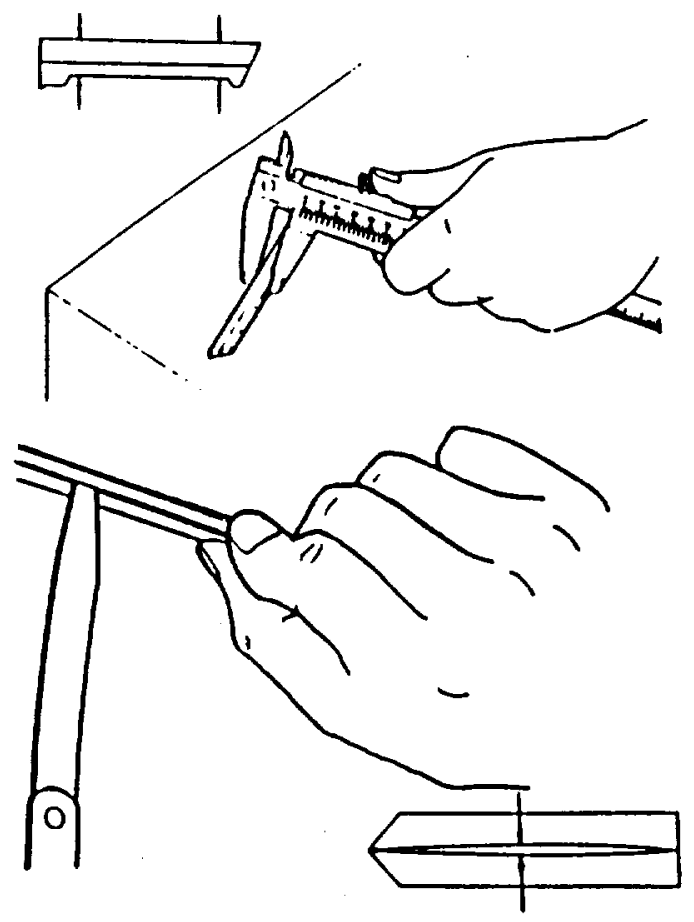

2. Check the apex seals for warpage.

Warpage Limit: $\quad 0.06 \mathrm{~mm}$

$$
(0.0024 \text { in. })
$$




\section{ORIGINA! FREF IS \\ OF POOR QUALTY}

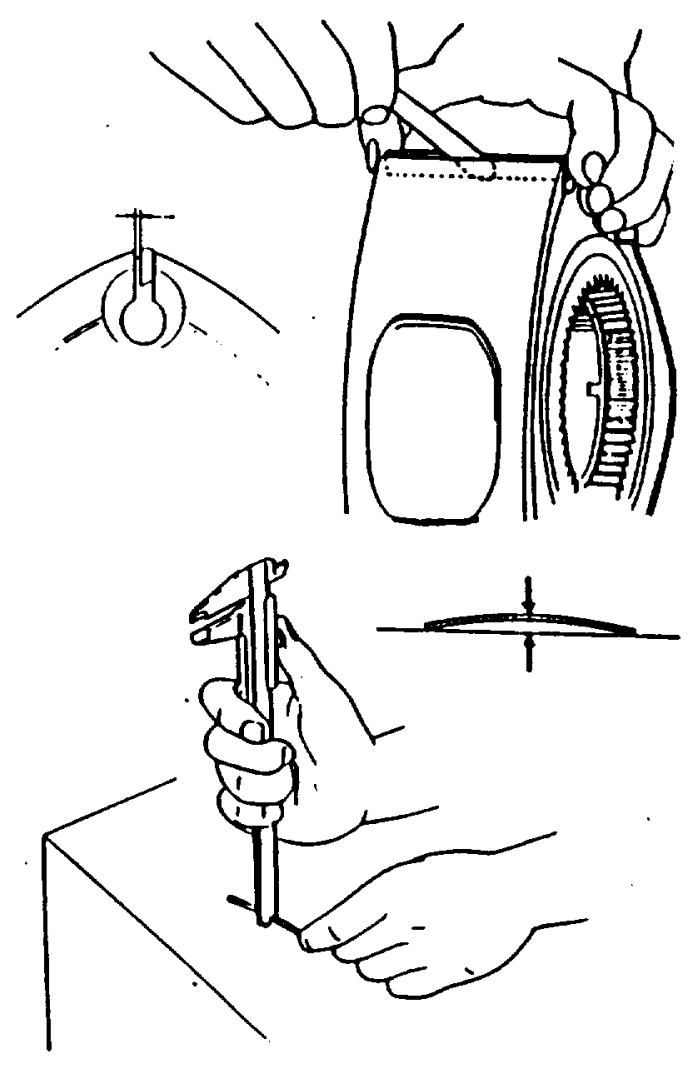

$79.9-80.1 \mathrm{~mm}$

$(3.146-3.154$ in $)$
APEX SEAL cont.

3. Check the clearance of the apex seal and the groove.

Standard clearance: $0.062-0.102 \mathrm{~mm}$

$(.0024-.004$ in.)

Clearance Limit: $\quad 0.15 \mathrm{~mm}$

$(.0059$ in. $)$

4. Check the apex seal spring for wear and free height.

Free Height Limit:

Long Spring

$$
\begin{aligned}
& 4.6 \mathrm{~mm} \\
& (.181 \mathrm{in.})
\end{aligned}
$$

5. Measure the apex seal length.

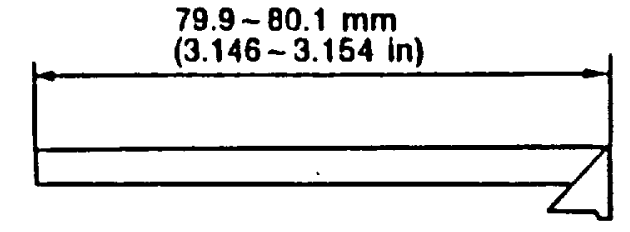

\section{SIDE SEAL}

1. Check side seal protrusion.

Protrusion: $0.5 \mathrm{~mm}$

(.020 in.) min.

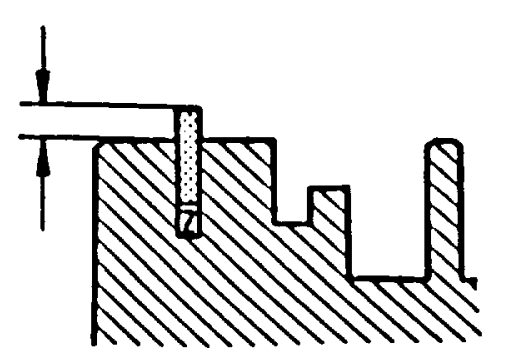


SIDE SEAL cont.

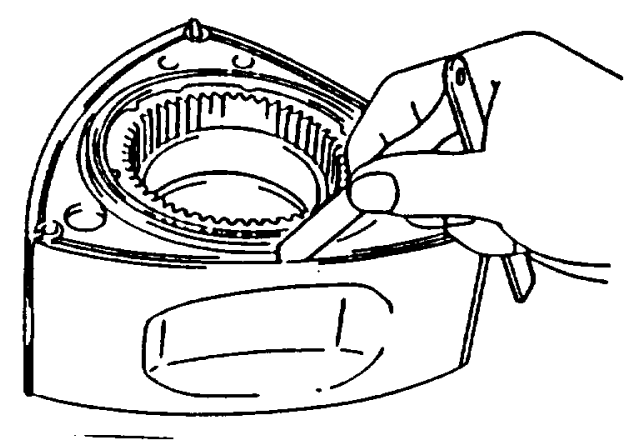

2. Check the clearance between the side seal and the groove.

Standard Clearance: $0.028-0.078 \mathrm{~mm}$

$(.0011-.0031$ in. $)$

Clearance Limit: $\quad 0.10 \mathrm{~mm}$

$$
(.0039 \mathrm{in.})
$$

3. Check the clearance between the side seal and the corner seal.

Standard Clearance: $0.05-0.15 \mathrm{~mm}$

$(0.0020-0.0059$ in.)

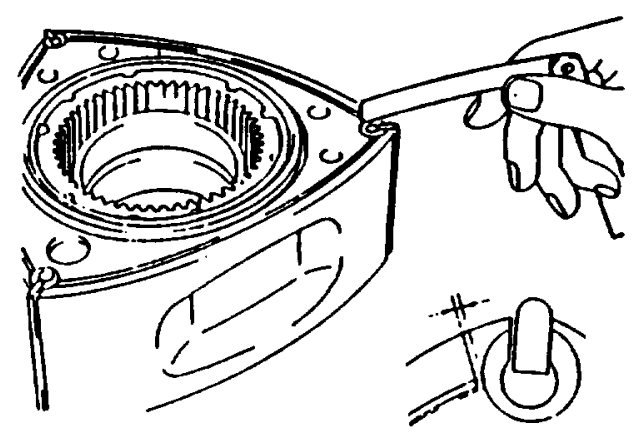

$\begin{array}{ll}\text { Clearance Limit: } & 0.4 \mathrm{~mm} \\ & (.016 \mathrm{in.})\end{array}$

CORNER SEAL

Check the corner seal protrusion.

Protrusion: $\quad 0.5 \mathrm{~mm}$

(.020 in) min.

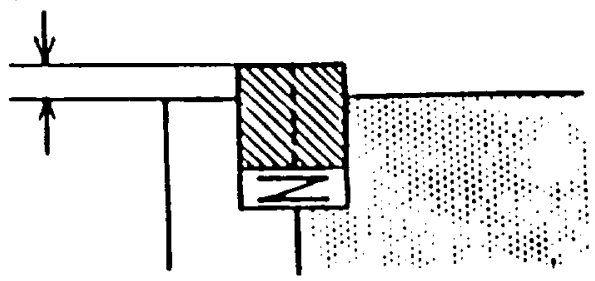




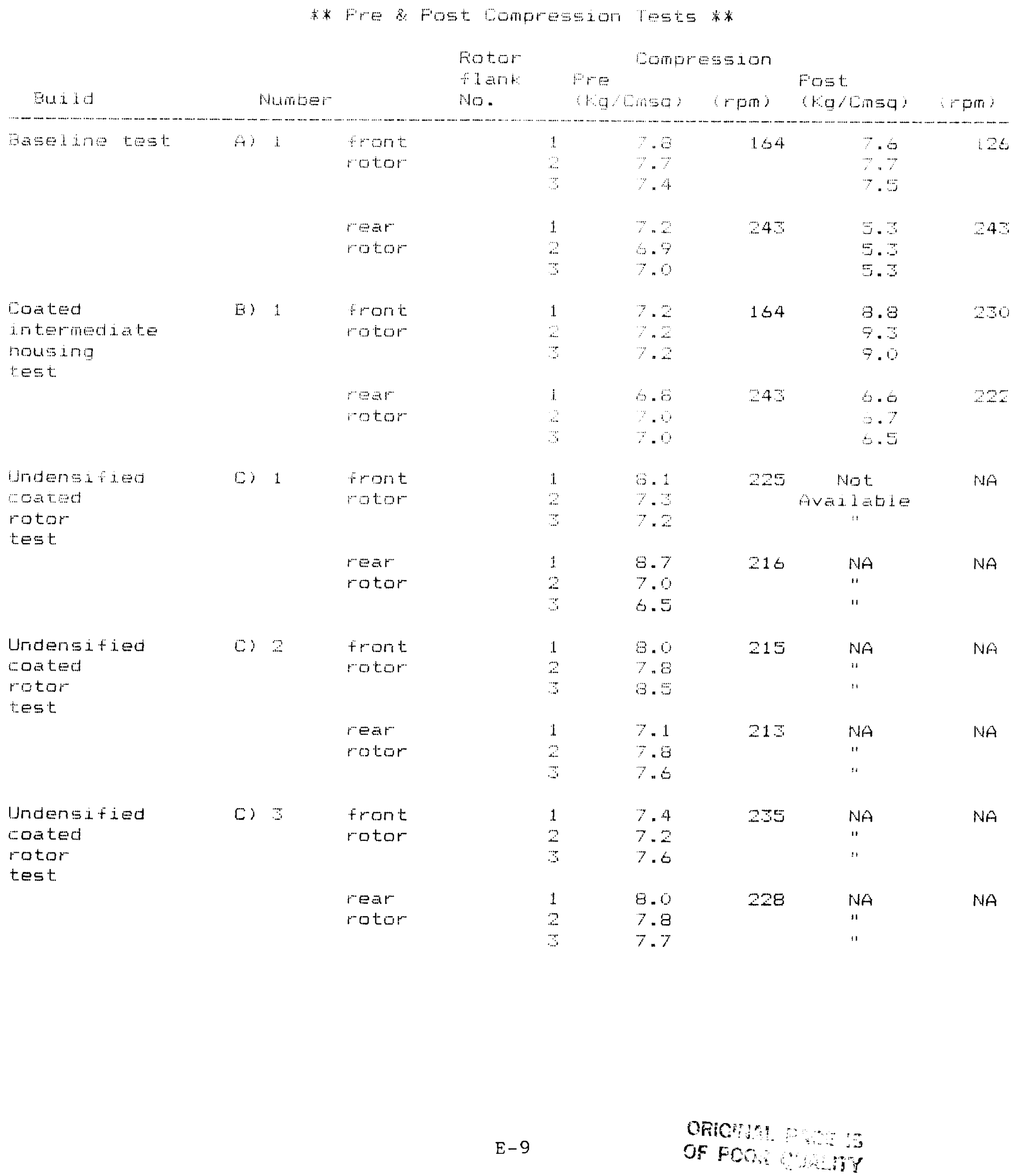


* Fre \& Fost Compression Tests

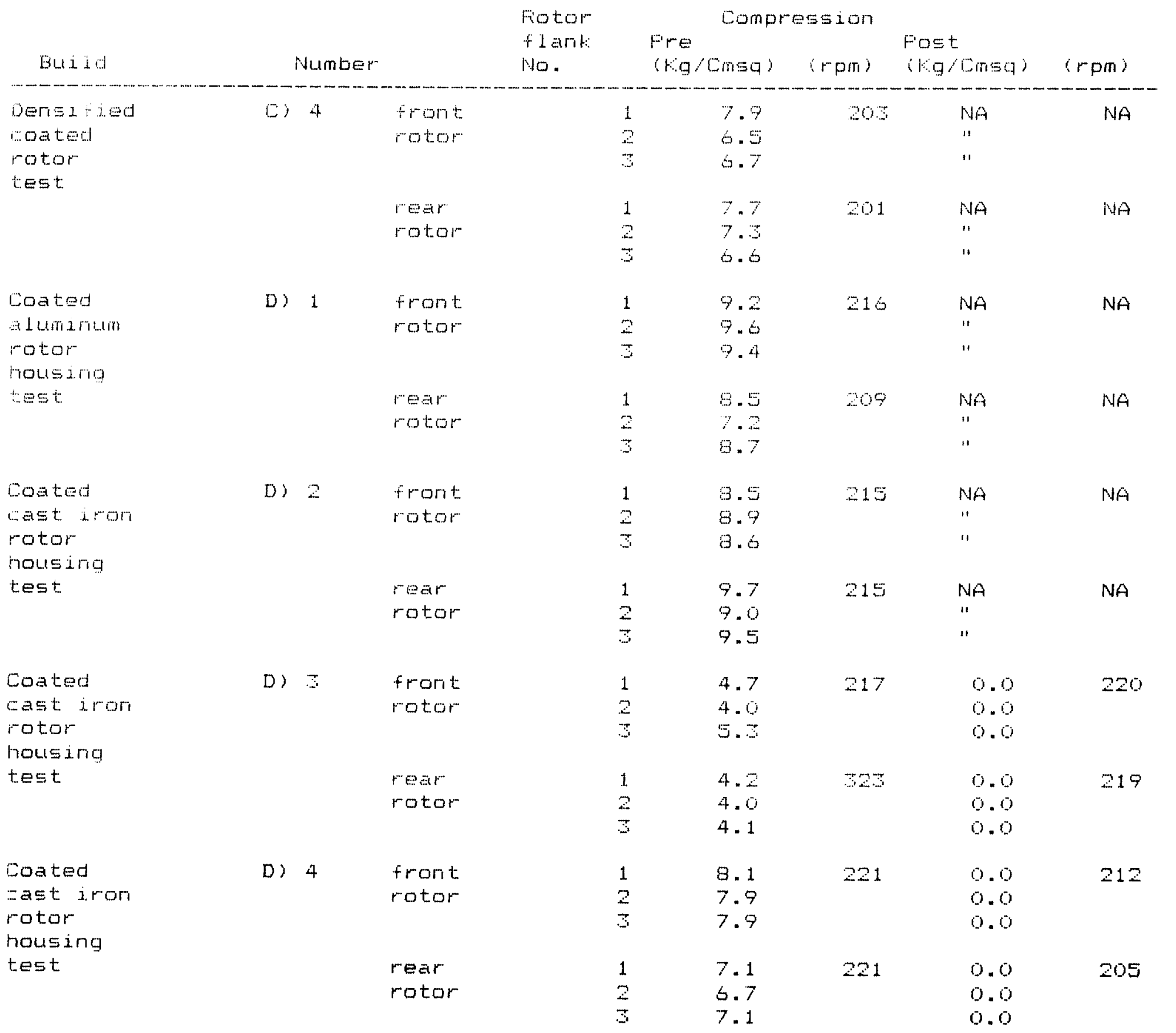


* Front Majr Eearing Cilearance **

\begin{tabular}{|c|c|c|c|c|c|c|c|}
\hline $\begin{array}{l}\text { ithi } \\
\text { Mun }\end{array}$ & $\begin{array}{l}1 \\
\text { abe }\end{array}$ & $\begin{array}{l}\text { Gtandard } \\
\text { bearance } \\
\text { inch }\end{array}$ & $\begin{array}{l}\text { Clearance } \\
\text { Limit } \\
\text { (inch) }\end{array}$ & $\begin{array}{l}\text { FrE } \\
\text { (inch) }\end{array}$ & $\begin{array}{l}F r e \\
(\mathrm{mrm})\end{array}$ & $\begin{array}{l}\text { Fost } \\
\text { (inch) }\end{array}$ & $\begin{array}{l}\text { Fost } \\
\text { (mon) }\end{array}$ \\
\hline$A$ & $i$ & $\begin{array}{l}.0016 \\
+0 \\
0.00-31\end{array}$ & 9.009 & 3.020 & 0.0509 & 0.1020 & 0.000 \\
\hline$B)$ & $\perp$ & & & 9.0020 & $0.0,58$ & 0.000 & 0.0508 \\
\hline 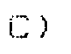 & 1 & & & 0.0020 & 9.050 & 0.0020 & 0.0508 \\
\hline $\mathrm{E})$ & 2 & & & 0.0020 & 0.0508 & 0.0020 & 0.0508 \\
\hline 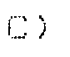 & $r$ & & & 0.0020 & 0.0508 & 0.0029 & 0.0711 \\
\hline$(\ldots)$ & 4 & & & 10029 & 9.6797 & 0.000 & 0.076 \\
\hline D) & 1 & & & 0.0030 & 0.076 & 0.000 & 10762 \\
\hline $0 \%$ & $\because$ & & & ० 100 & 9.0762 & $0,0,0$ & 10.076 \\
\hline D) & $\therefore$ & & & 0.0030 & 0.0762 & 0.0030 & 9.0765 \\
\hline Di & $A$ & & & $0.00 \pm 0$ & 0.0762 & 0.00 & 0.0762 \\
\hline
\end{tabular}

ORIGUVA r:SE:

OF POOR quAntTy 


\section{OBPH PACE IS \\ OF PUOR QUALITY}

\begin{tabular}{|c|c|c|c|c|c|c|c|}
\hline \multicolumn{8}{|c|}{ k * Fear Main } \\
\hline \multicolumn{2}{|c|}{$\begin{array}{l}\text { Build } \\
\text { Number }\end{array}$} & $\begin{array}{l}\text { Standard } \\
\text { clearance } \\
\text { inch) }\end{array}$ & $\begin{array}{l}\text { Clearance } \\
\text { imitim } \\
\text { inch) }\end{array}$ & $\begin{array}{l}\text { Fre } \\
\text { (inch) }\end{array}$ & $\begin{array}{l}\text { Fire } \\
(\min )\end{array}$ & $\begin{array}{l}\text { Fost } \\
\text { (inch) }\end{array}$ & $\begin{array}{l}\text { Fost } \\
(\mathrm{mm})\end{array}$ \\
\hline A) & 1 & $\begin{array}{l}0.0016 \\
\operatorname{ta} \\
.0031\end{array}$ & 0.0059 & 0.0020 & 0.0508 & 0.0020 & 0.0508 \\
\hline s) & l & & & 0.0020 & 0.0508 & 0.0020 & 0.0508 \\
\hline c) & 1 & & & 0.0020 & 0.0509 & 0.0020 & 0.0508 \\
\hline ) & 2 & & & 0.0020 & 0.0508 & 0.0020 & 0.0508 \\
\hline 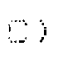 & $\%$ & & & 0.0020 & 0.0508 & 0.0028 & 0.0711 \\
\hline \% & 4 & & & 0.0028 & 0.0711 & 0.0028 & 0.0711 \\
\hline$D)$ & 1 & & & 0.0029 & 0.0757 & 0.0029 & $0.07 \%$ \\
\hline D) & $\therefore$ & & & 0.0029 & 0.0757 & 0.0000 & 0.0762 \\
\hline D) & $\Xi$ & & & 0.0030 & 0.0762 & 0.0030 & 0.0762 \\
\hline D) & 4 & & & 0.00 .0 & 0.0762 & 0.0030 & 0.0762 \\
\hline
\end{tabular}




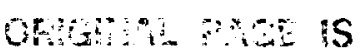

OF POUR QUALITY

* Front fotor Bearing Clearance **

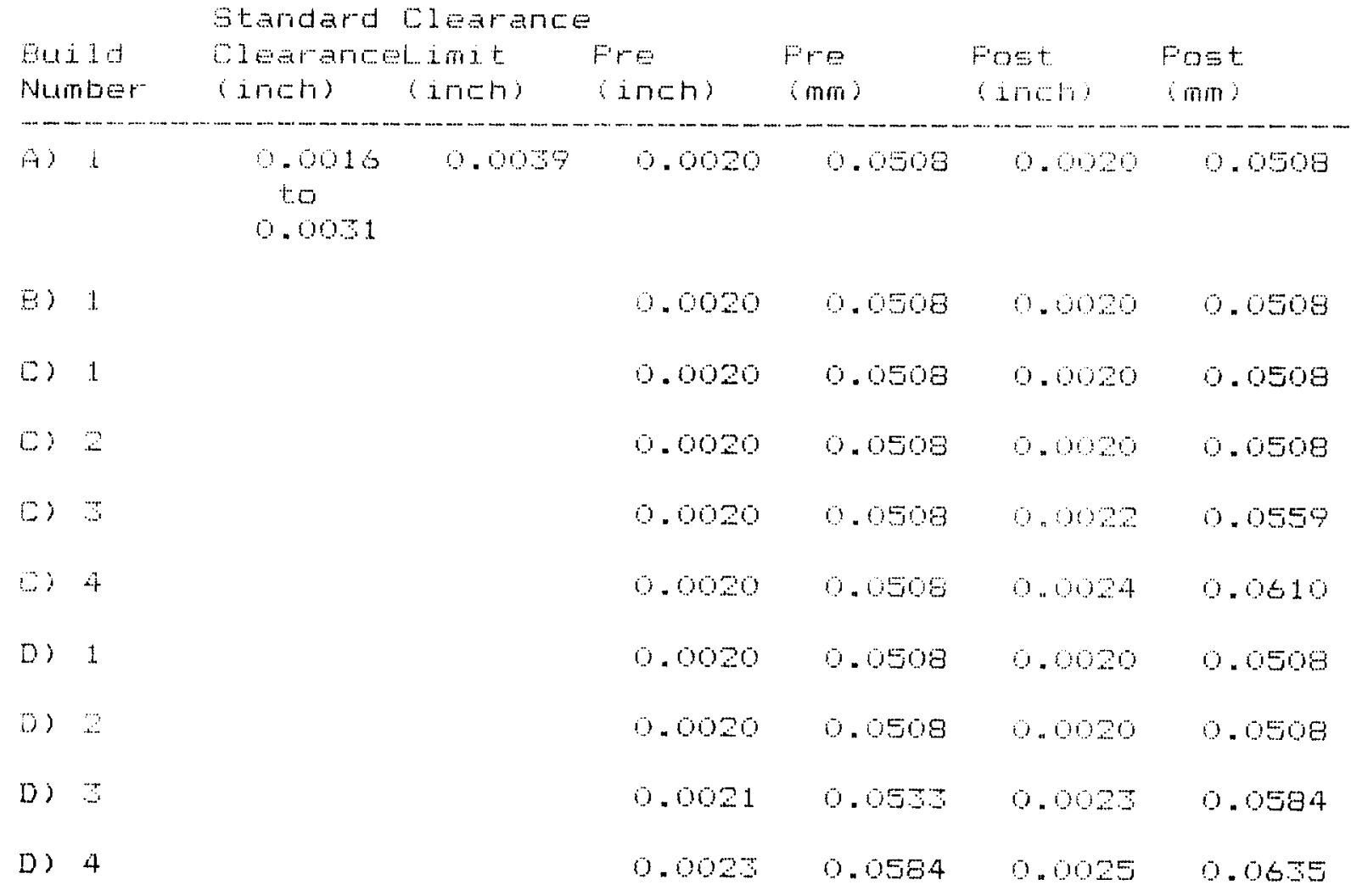


CF

* Fear Fotor Eearing Clearance **

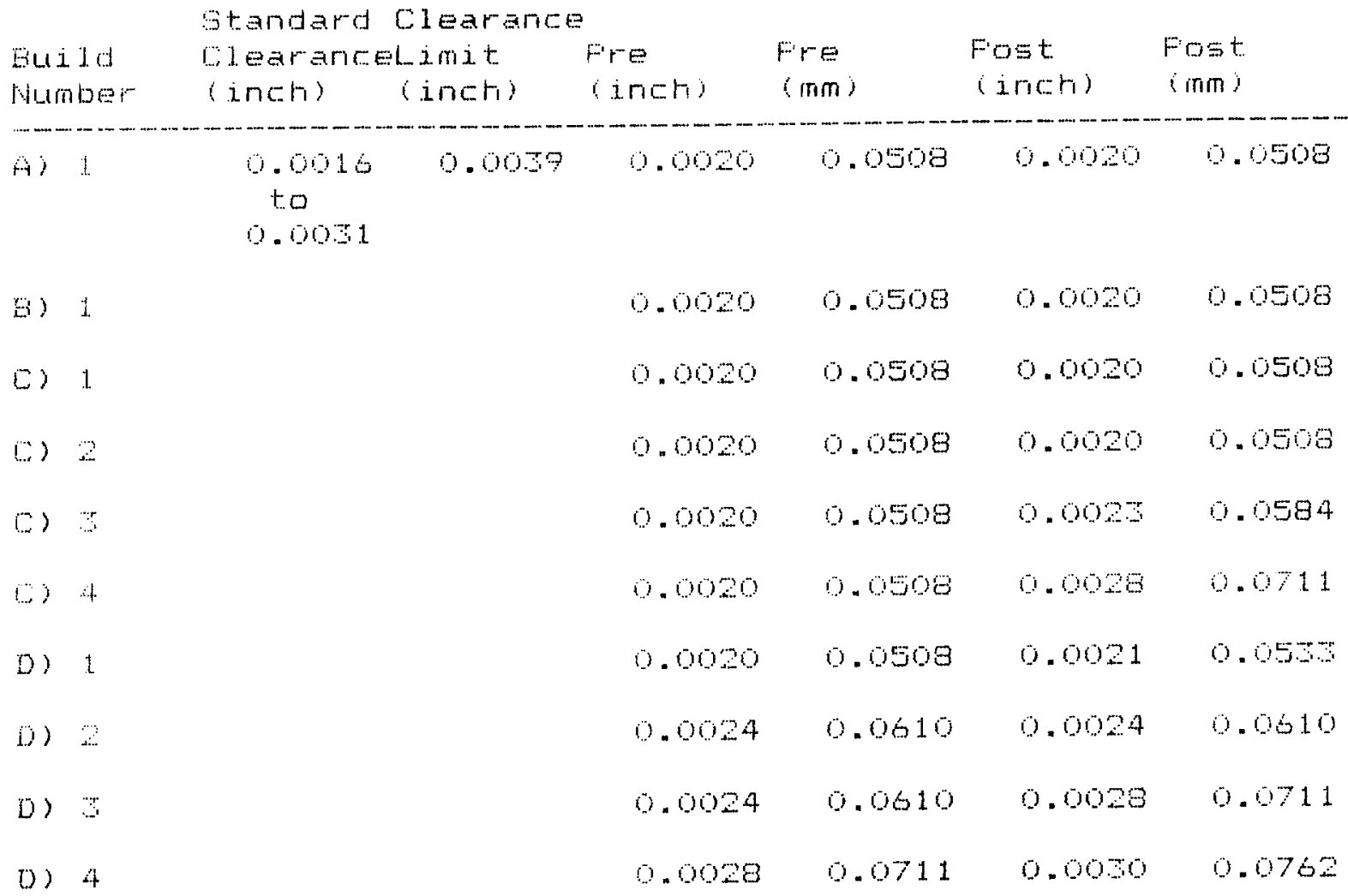




\section{OR:GINAE PAGE IS OF POOR QUALITY}

** Front Fotor Housing width Difterence w $^{*}$

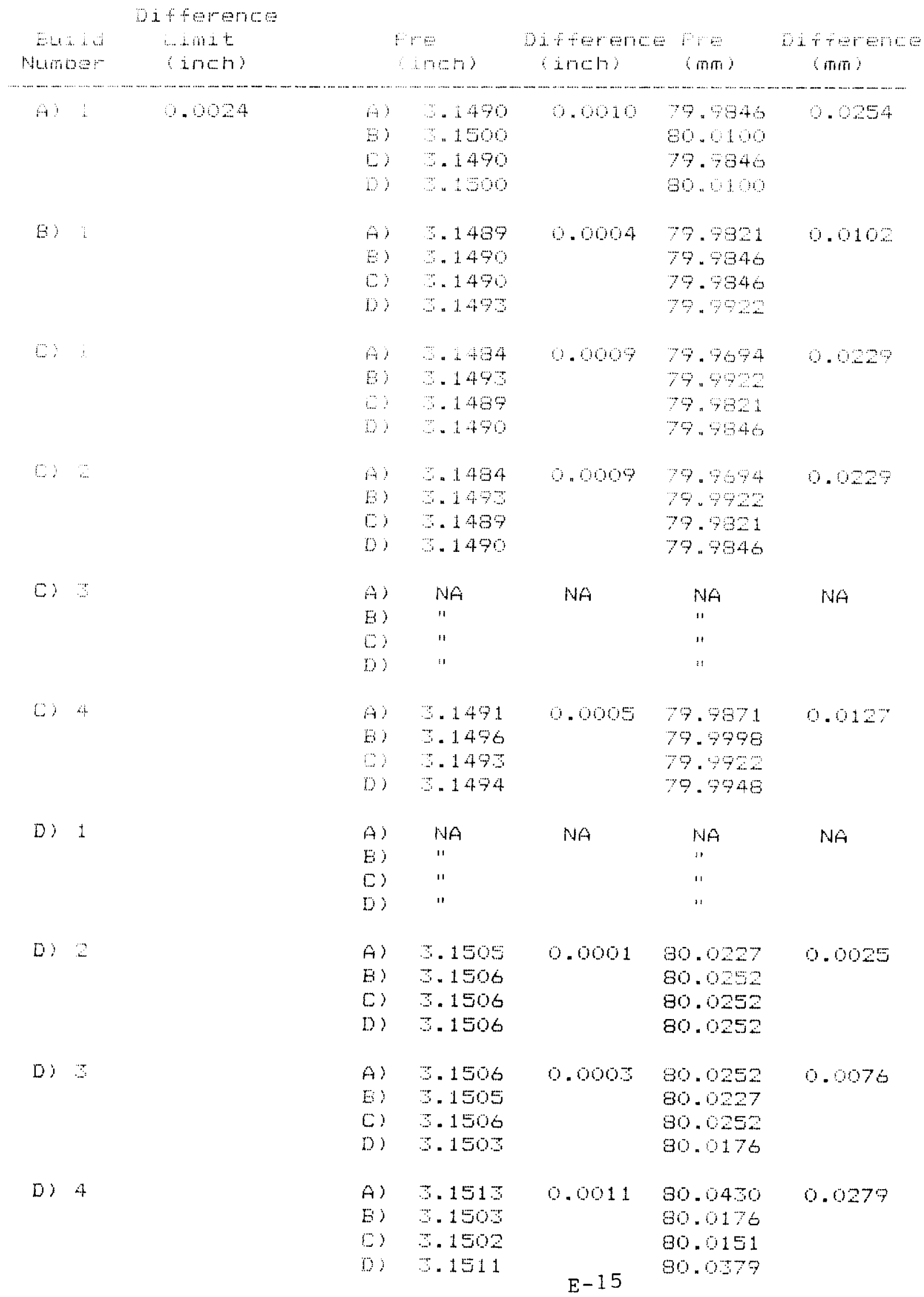




\section{Cnigin nroe is \\ OF POJE QUALITY}

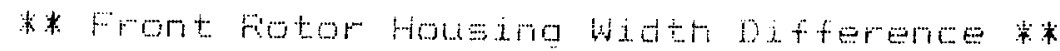

\begin{tabular}{|c|c|c|c|c|c|c|c|}
\hline $\begin{array}{l}\text { Eul } \\
\text { rumt }\end{array}$ & $\begin{array}{ll}10 \\
\text { iser }\end{array}$ & $\begin{array}{l}i t \text { tereno } \\
\text { imit } \\
\text { incti }\end{array}$ & & $\begin{array}{l}\text { ost } \\
\text { (inct) }\end{array}$ & $\begin{array}{l}\text { Difference } \\
\text { inch }\end{array}$ & $\begin{array}{c}e r s t \\
(m m)\end{array}$ & 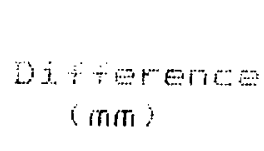 \\
\hline$A)$ & . & 0.0024 & $\begin{array}{l}\text { A) } \\
\text { ह) } \\
\text { C) } \\
\text { b) }\end{array}$ & $\begin{array}{l}\because 149 \% \\
3.1490 \\
\therefore .1490 \\
\because .1490\end{array}$ & .0004 & $\begin{array}{l}79.9621 \\
79.9646 \\
79.9346 \\
79.9722\end{array}$ & ओणू \\
\hline$\theta$ & : & & $\begin{array}{l}A) \\
B> \\
D \\
D\end{array}$ & $\begin{array}{l}.1494 \\
.149 \\
.1499 \\
.1490\end{array}$ & 0.0009 & $\begin{array}{l}79.9694 \\
79.9922 \\
79.9621 \\
79.9646\end{array}$ & 0.0229 \\
\hline $\mathrm{C}$ & : & & $\begin{array}{l}A) \\
B) \\
B) \\
\cdots\end{array}$ & $\begin{array}{l}=1484 \\
=1493 \\
=1489 \\
-149\end{array}$ & 0.0009 & $\begin{array}{l}79.9694 \\
79.9922 \\
79.9921 \\
79.9946\end{array}$ & $0.02 \%$ \\
\hline 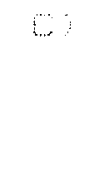 & & & $\begin{array}{l}A ; \\
B ; \\
D ; \\
D\end{array}$ & $\begin{array}{l}\mathrm{NA} \\
11 \\
11 \\
" 1\end{array}$ & $N A$ & $\begin{array}{l}\text { NA } \\
" 1 \\
" 1 \\
" 1\end{array}$ & $\mathrm{NA}$ \\
\hline$C$ & $\because$ & & $\begin{array}{l}A) \\
B) \\
C ; \\
D ?\end{array}$ & $\begin{array}{l}x .1491 \\
.149 \% \\
.1494 \\
x .1496\end{array}$ & 0.0005 & $\begin{array}{l}79.9871 \\
79.9922 \\
79.9948 \\
79.9998\end{array}$ & $0.012 \%$ \\
\hline $\mathrm{O}$ & $\because$ & & $\begin{array}{l}A) \\
B) \\
C) \\
D)\end{array}$ & $\begin{array}{l}x .1494 \\
=1490 \\
.1490 \\
.1490\end{array}$ & 0.0006 & $\begin{array}{l}79.9694 \\
79.9846 \\
79.9846 \\
79.9846\end{array}$ & 0.0 \\
\hline D) & 1 & & $\begin{array}{l}A) \\
B) \\
C) \\
D\end{array}$ & $\begin{array}{l}3.1473 \\
-146 \Xi \\
3.1463 \\
3.1468\end{array}$ & 0.0010 & $\begin{array}{l}79.9414 \\
79.9160 \\
79.9160 \\
79.9287\end{array}$ & 0.0254 \\
\hline D) & 2 & & $\begin{array}{l}\text { A) } \\
\text { B) } \\
\text { C) } \\
\text { D) }\end{array}$ & $\begin{array}{l}\Xi .1506 \\
\Xi .1505 \\
\Xi .1506 \\
3.1500\end{array}$ & 0.0003 & $\begin{array}{l}30.0252 \\
60.0227 \\
80.0252 \\
80.0176\end{array}$ & 0.0070 \\
\hline D) & $\Xi$ & & $\begin{array}{l}\text { A) } \\
\text { B) } \\
\text { C) } \\
\text { D) }\end{array}$ & $\begin{array}{l}\because .1506 \\
.1505 \\
.1506 \\
3.1503\end{array}$ & 0.0005 & $\begin{array}{l}30.0252 \\
80.0227 \\
30.0252 \\
80.0176\end{array}$ & 0.0076 \\
\hline 0$)$ & 4 & & $\begin{array}{l}\text { A) } \\
\text { E) } \\
\text { C) } \\
\text { D) }\end{array}$ & $\begin{array}{l}\Xi 1505 \\
\therefore .1500 \\
\Xi .1507 \\
.1507\end{array}$ & $0.000 \mathrm{E}$ & $\begin{array}{l}80.0227 \\
80.0303 \\
80.0278 \\
80.0278\end{array}$ & 0.0076 \\
\hline
\end{tabular}


ORIGINAL PAEE IS

OF POOR QUALITY

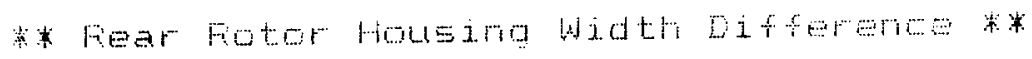

\begin{tabular}{|c|c|c|c|c|c|c|c|}
\hline 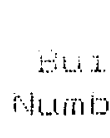 & & $\begin{array}{l}\text { ferenoe } \\
\text { tinit } \\
\text { inch }\end{array}$ & & Mati & 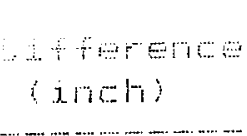 & (mitio & 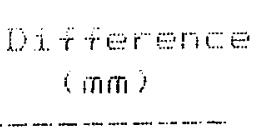 \\
\hline 9 & 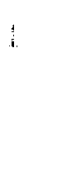 &, 0024 & $\begin{array}{l}\mathrm{H} \\
\mathrm{E} \\
\mathrm{C} ; \\
\mathrm{D})\end{array}$ & $\begin{array}{l}r .490 \\
y-1900 \\
-1500 \\
-1000\end{array}$ & al & $\begin{array}{l}-9640 \\
0,110 \\
90.4100 \\
90.100\end{array}$ & 9.0254 \\
\hline$B$ & 1 & & $\begin{array}{l}a j \\
B) \\
\mathrm{C}) \\
\mathrm{Di}\end{array}$ & $\begin{array}{l}\because .191 \\
\because=1491 \\
-149 \\
\because 1471\end{array}$ & 0.000 & $\begin{array}{l}79.971 \\
79.967 \\
79.9940 \\
7.9 \% 1\end{array}$ & 0.076 \\
\hline$\ldots$ & $i$ & & $\begin{array}{l}\mathrm{A} ; \\
\mathrm{B} ; \\
\mathrm{B} ;\end{array}$ & $\begin{array}{l}\because .144 \\
\because 148 \% \\
\because .148 \\
\cdots .1499\end{array}$ & $0.0,0$ & $\begin{array}{l}79.994 \\
79.919 \\
79.99 \% \\
7.96-1\end{array}$ & 0.12 \\
\hline $\mathrm{C}$ & $\therefore$ & & $\begin{array}{l}A \\
b i \\
C \\
D\end{array}$ & $\begin{array}{l}-1484 \\
\cdots 1489 \\
\because=1489 \\
\because 1489\end{array}$ & 0.0005 & $\begin{array}{l}79.994 \\
79.919 \\
79.979 \\
79.9021\end{array}$ & 9.21 \\
\hline Cj & $\xi$ & & $\begin{array}{l}\text { A) } \\
\text { B) } \\
C) \\
D\end{array}$ & $\begin{array}{l}\text { NA } \\
" 1 \\
" 1 \\
"\end{array}$ & $N A$ & $\begin{array}{l}\mathrm{HA} \\
" 1 \\
1 \\
1\end{array}$ & $N A$ \\
\hline $\mathrm{B})$ & 4 & & $\begin{array}{l}A \\
B) \\
C \\
D\end{array}$ & $\begin{array}{l}\because-1490 \\
\because .1502 \\
\because .149 \\
\because 1492\end{array}$ & 0.01012 & $\begin{array}{l}79.936 \\
60.9151 \\
79.9722 \\
79.9677\end{array}$ & $0.0 \%$ \\
\hline D) & $t$ & & $\begin{array}{l}\text { A) } \\
\text { E) } \\
\text { C) } \\
\text { D) }\end{array}$ & $\begin{array}{l}\text { NA } \\
" 1 \\
" 1\end{array}$ & $\mathrm{NA}$ & $\begin{array}{l}M A \\
" 1 \\
11 \\
" 1\end{array}$ & NA \\
\hline D) & $\therefore$ & & $\begin{array}{l}\text { A) } \\
\text { B) } \\
\text { C) } \\
D)\end{array}$ & $\begin{array}{l}\because .1505 \\
\because .1505 \\
\because .1504 \\
=1507\end{array}$ & $0.000 \%$ & $\begin{array}{l}90.0227 \\
80.0227 \\
80.0202 \\
80.0278\end{array}$ & 0.0076 \\
\hline$D ;$ & 4 & & $\begin{array}{l}\text { Ai } \\
\text { E) } \\
\text { C) } \\
\text { D) }\end{array}$ & $\begin{array}{l}\because .1505 \\
=.1505 \\
=1504 \\
=1507\end{array}$ & 0.0003 & $\begin{array}{l}90.0227 \\
00.0227 \\
60.0202 \\
80.0278\end{array}$ & 0.0076 \\
\hline D) & 4 & & $\begin{array}{l}\text { A) } \\
\text { B) } \\
\text { C) } \\
\text { D) }\end{array}$ & $\begin{array}{l}\square .1504 \\
=.1504 \\
\because .1507 \\
\square .1506\end{array}$ & 0.0003 & $\begin{array}{l}30.0202 \\
80.0202 \\
80.0270 \\
60.0252\end{array}$ & 0.0076 \\
\hline
\end{tabular}




\section{CRIGIMI FAOE IS \\ OF POOR QUALITY}

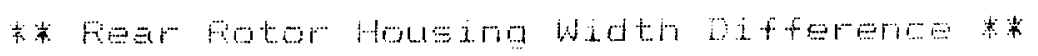

\begin{tabular}{|c|c|c|c|c|c|c|c|}
\hline $\begin{array}{l}\text { Eut } \\
\text { numb }\end{array}$ & $\operatorname{Lin}$ & $\begin{array}{l}\text { ifference } \\
\text { bimit } \\
\text { inch }\end{array}$ & & $\begin{array}{l}0 t \\
n e n\end{array}$ & $\begin{array}{l}\text { oxfference } \\
\text { (inch) }\end{array}$ & $\begin{array}{l}F o s t \\
\text { inin }\end{array}$ & $\begin{array}{c}D D+f e r e m c e \\
(\mathrm{~mm})\end{array}$ \\
\hline$A$ i & $\mathrm{t}$ & .0024 & $\begin{array}{l}A j \\
B j \\
C ; \\
0 ;\end{array}$ & $\begin{array}{l}\therefore .1491 \\
\therefore .1991 \\
\because .1494 \\
\therefore .1494\end{array}$ & .0007 & $\begin{array}{l}79.9971 \\
79.9971 \\
79.9949 \\
79.9946\end{array}$ & 0.0178 \\
\hline E) & 1 & & $\begin{array}{l}A) \\
b i \\
b i \\
b)\end{array}$ & $\begin{array}{l}.1484 \\
.1489 \\
.1488 \\
.1489\end{array}$ & 0.0005 & $\begin{array}{l}79.9694 \\
79.9719 \\
79.9795 \\
79.9921\end{array}$ & 0.0127 \\
\hline$\omega$ & $i$ & & $\begin{array}{l}A ; \\
b ; \\
b ; \\
b i\end{array}$ & $\begin{array}{l}.2494 \\
\cdots 1485 \\
.1489 \\
\therefore .1469\end{array}$ & 0.0005 & $\begin{array}{l}79.9694 \\
79.9719 \\
79.9793 \\
79.9621\end{array}$ & 0.0127 \\
\hline$\because$ & 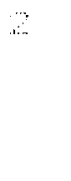 & & $\begin{array}{l}\text { a) } \\
E) \\
D i \\
D)\end{array}$ & $\begin{array}{l}\text { NA } \\
: " \\
" 1 \\
" 1\end{array}$ & HA & $\begin{array}{l}\mathrm{NA} \\
: " \\
" 1 \\
" 1\end{array}$ & $\mathrm{NA}$ \\
\hline C) & $x$ & & $\begin{array}{l}A) \\
\text { E) } \\
C ; \\
D ?\end{array}$ & $\begin{array}{l}\therefore .1490 \\
\therefore .1496 \\
\therefore .1495 \\
\therefore .1495\end{array}$ & 0.0000 & $\begin{array}{l}79.9946 \\
79.9998 \\
79.9975 \\
79.9975\end{array}$ & $0.015=$ \\
\hline$B$ & it & & $\begin{array}{l}\text { A) } \\
\text { Bi } \\
\text { Ci } \\
D i\end{array}$ & $\begin{array}{l}\because 1490 \\
=1498 \\
\Xi .1497 \\
\therefore .1496\end{array}$ & 0.000 & $\begin{array}{l}79.9846 \\
80.0049 \\
30.0024 \\
79.9998\end{array}$ & $0.020 \%$ \\
\hline D) & 1 & & $\begin{array}{l}\text { A) } \\
\text { B) } \\
\text { C) } \\
\text { D) }\end{array}$ & $\begin{array}{l}\therefore 1497 \\
\therefore .1509 \\
\because 1495 \\
\therefore 1502\end{array}$ & 0.0022 & $\begin{array}{l}79.9770 \\
80.0329 \\
79.9772 \\
60.0151\end{array}$ & 0.0559 \\
\hline D) & 2 & & $\begin{array}{l}\text { A) } \\
\text { E) } \\
\text { C) } \\
\text { D) }\end{array}$ & $\begin{array}{l}\because .1505 \\
.1505 \\
3.1504 \\
\therefore .1507\end{array}$ & $0.000 \mathrm{Z}$ & $\begin{array}{l}80.0227 \\
80.0227 \\
80.0202 \\
80.0278\end{array}$ & 0.0076 \\
\hline D) & 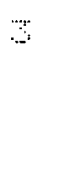 & & $\begin{array}{l}\text { A) } \\
\text { B) } \\
\text { C) } \\
\text { D) }\end{array}$ & $\begin{array}{l}\because .1505 \\
\because .1506 \\
\Xi .1504 \\
\therefore .1505\end{array}$ & 0.0002 & $\begin{array}{l}30.0227 \\
30.0252 \\
30.0202 \\
80.0227\end{array}$ & 0.0051 \\
\hline D) & 4 & & $\begin{array}{l}\text { A) } \\
\text { B) } \\
\text { C) } \\
D ?\end{array}$ & $\begin{array}{l}x .1505 \\
\cdot .1504 \\
\times .1505 \\
\times .1506\end{array}$ & 0.0002 & $\begin{array}{l}80.0227 \\
80.0202 \\
80.0227 \\
80.0252\end{array}$ & 0.0051 \\
\hline
\end{tabular}




\begin{tabular}{|c|c|c|c|c|c|c|c|}
\hline \multicolumn{2}{|c|}{$\begin{array}{l}\text { Buid } 1 \text { d } \\
\text { Number }\end{array}$} & $\begin{array}{l}\text { Standard } 0 \\
\text { olearance } \\
\text { inch) }\end{array}$ & $\begin{array}{l}\text { earance } \\
\text { Limit } \\
(\operatorname{inch})\end{array}$ & $\begin{array}{l}\text { Fre } \\
\text { (inch) }\end{array}$ & $\begin{array}{l}\text { Fre } \\
\text { imm }\end{array}$ & $\begin{array}{l}\text { Fost } \\
\text { (ingh) }\end{array}$ & $\begin{array}{l}\text { Fost } \\
\text { (mon) }\end{array}$ \\
\hline (i) & $t$ & $\begin{array}{l}.0047 \\
100 \\
.0083\end{array}$ & 0.0040 & $N A$ & $N A$ & 0.0001 & 0.1549 \\
\hline E) & 1 & & & 0.0061 & 0.1549 & 0.0069 & 0.1753 \\
\hline C: & 1 & & & 0.0060 & 0.1524 & 0.0060 & 0.1524 \\
\hline C) & 2 & & & 0.0060 & 0.1524 & 0.0060 & 0.1524 \\
\hline D) & $\therefore$ & & & 0.0072 & 0.1929 & 0.0073 & 0.1354 \\
\hline E: & 4 & & & 0.0070 & 0.1778 & $0_{00 \% 1}$ & 0.1005 \\
\hline b) & 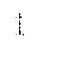 & & & .0000 & $0.20 \mathrm{z}$ & .0001 & 0.2057 \\
\hline Di & 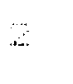 & & & 0.0081 & 0.2057 & .0081 & 0.2057 \\
\hline D) & $\therefore$ & & & 0.0081 & 0.2057 & 0.0082 & o) 209 \\
\hline D) & 4 & & & 0.0082 & 0.2085 & 0.0082 & 0.2083 \\
\hline
\end{tabular}




\begin{tabular}{|c|c|c|c|c|c|c|c|}
\hline \multicolumn{2}{|c|}{$\begin{array}{l}\text { Euid } 1 \\
\text { Number }\end{array}$} & $\begin{array}{l}\text { Standard } \\
\text { Clearance } \\
\text { (inch) }\end{array}$ & $\begin{array}{l}\text { learance } \\
\text { Limit } \\
\text { (inch) }\end{array}$ & $\begin{array}{l}\text { Fre } \\
\text { (inch) }\end{array}$ & $\begin{array}{l}\text { Fre } \\
\text { (inm) }\end{array}$ & $\begin{array}{l}\text { Fost } \\
\text { (inch) }\end{array}$ & $\begin{array}{l}\text { Fost } \\
\text { (inm) }\end{array}$ \\
\hline$A$ & 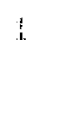 & $\begin{array}{l}0.0047 \\
t 0 \\
0.0083\end{array}$ & 0.0040 & Nit & NA & $0.00 \% 1$ & 0.1503 \\
\hline E) & 1 & & & 0.0067 & 0.1702 & 0.0067 & 0.1753 \\
\hline$C$ & $i$ & & & 0.0070 & 0.1778 & 0.0070 & 0.1778 \\
\hline E) & 2 & & & 0.0070 & 0.1778 & 0.0070 & 0.1778 \\
\hline$C ;$ & - & & & 0.0071 & 0.1803 & 0.0071 & $0.180 \mathrm{~S}$ \\
\hline$C$ & 4 & & & 0.0065 & 0.1651 & 0.0065 & 0.1651 \\
\hline D) & i & & & 0.0065 & 0.1651 & 0.0060 & 0.1676 \\
\hline D) & $z$ & & & 0.0080 & 0.202 & 0.0082 & 0.2083 \\
\hline D) & $\dot{s}$ & & & 0.0002 & 0.2083 & 0.0083 & 0.2108 \\
\hline D) & 4 & & & 0.0083 & 0.2108 & 0.0083 & 0.2108 \\
\hline
\end{tabular}


ORIGINDL PAGE IS

OF POOR QUALITY

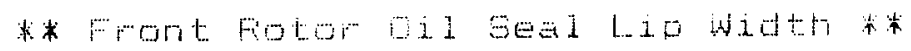

\begin{tabular}{|c|c|c|c|c|c|c|c|c|}
\hline \multicolumn{2}{|c|}{$\begin{array}{l}\text { Busda } \\
\text { Number }\end{array}$} & \multicolumn{3}{|l|}{$\begin{array}{c}\text { Eandard } \\
\text { incio }\end{array}$} & $\begin{array}{l}\text { Fre } \\
\text { (imen) }\end{array}$ & $\begin{array}{l}\text { Pre } \\
\text { mon }\end{array}$ & $\begin{array}{l}\text { Post } \\
\text { (ineti) }\end{array}$ & $\begin{array}{l}0=t \\
\min \end{array}$ \\
\hline \multirow[t]{4}{*}{$A$} & 1 & max & gear & AnחЕr & $\mathrm{NA}$ & NH & NA & $M A$ \\
\hline & & 0.0200 & side & outer & $N A$ & $\mathrm{HA}$ & $N F_{i}$ & $N A$ \\
\hline & & & platir & driner & $\mathrm{NA}$ & $N A$ & NA & NA \\
\hline & & & эide & wuter & $N A$ & $\mathrm{NA}$ & $N A$ & $\mathrm{Ni}$ \\
\hline \multirow[t]{4}{*}{$B$} & 1 & & gear & LMner & 0.0110 & 9.2794 & 0.0200 & 0.5080 \\
\hline & & & ज्de & outer & 0.0100 & - .2540 & 0.0140 & . . 550 \\
\hline & & & م1 & inrier & 0.0160 & o. 4964 & o. 400 & 1.0150 \\
\hline & & & $=i d E$ & outer & 0.0100 & $=25+4$ & .0400 & 1.0160 \\
\hline \multirow[t]{4}{*}{ i. } & & & $g=a r$ & Anmer & . .000 & $a-20$ & बकब० & . $20 \mathrm{z}$ \\
\hline & & & $31 d e$ & muter & 0.0000 & - 20 & .0030 & . $20 \mathrm{a}$ \\
\hline & & & piain & Limmer & .080 & a & . .000 & 0.202 \\
\hline & & & side & outer & .0000 & . & 0.0080 & $0.20 \mathrm{x}$ \\
\hline \multirow[t]{4}{*}{ C) } & 2 & & gear & inner & 0.0000 & 0.202 & 0.0000 & $0.20+2$ \\
\hline & & & 510 & outer & 0.0000 & $0.20 \mathrm{~T}$ & 0.0090 & $0.20 x$ \\
\hline & & & plain & inner & 0.0080 & $0 \times 2032$ & 0.0080 & 0.2032 \\
\hline & & & sde & outer & 0.0080 & 0.2012 & 0.0080 & $.20 \pi$ \\
\hline \multirow[t]{4}{*}{ C) } & 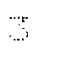 & & gear" & Lnner & 0.0080 & $0.20 \% 2$ & 0.0150 & 0.302 \\
\hline & & & 5100 & outer & 0.0000 & a $20 \mathrm{z}$ & 0.0120 & 0.840 \\
\hline & & & plain & inner & .0080 & a . 2002 & 0.0100 & .2540 \\
\hline & & & side & outer & 0.0080 & 0.205 & 0.0100 & 0.2540 \\
\hline \multirow[t]{4}{*}{ C) } & 4 & & gear & inner & 0.0110 & .2794 & 0.0130 & 0.502 \\
\hline & & & $s i d e$ & outer & 0.0100 & .2540 & 0.0130 & 0.3302 \\
\hline & & & م1 & inner & 0.0100 & 0.2540 & 0.0120 & 0.3048 \\
\hline & & & side & outer & 0.0110 & 0.2794 & 0.0150 & 0.5002 \\
\hline \multirow[t]{4}{*}{ D) } & 1 & & gear & iriner & 0.0150 & 0.3610 & 0.0180 & 0.4572 \\
\hline & & & side & outer & 0.0160 & 0.4064 & 0.0150 & 0.5810 \\
\hline & & & plain & inner & 0.0100 & $0 . \sec$ & 0.0140 & 0.3550 \\
\hline & & & side & outer & 0.0120 & 0.3049 & 0.0120 & 0.3048 \\
\hline \multirow[t]{4}{*}{ D) } & 2 & & gear & inner & 0.0120 & 0.8046 & 0.0130 & 0.0302 \\
\hline & & & side & outer & 0.0120 & 0.348 & 0.0150 & 0.3810 \\
\hline & & & plain & immer & 0.0120 & 0.0049 & 0.0130 & 0.3502 \\
\hline & & & side & outer & 0.0200 & ). 5080 & 0.0140 & 0.3556 \\
\hline
\end{tabular}




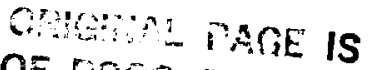 \\ OF POOR QUALITY}

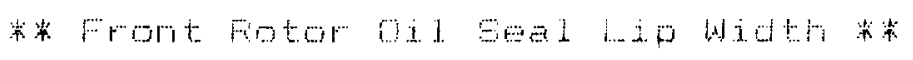

\begin{tabular}{|c|c|c|c|c|c|c|c|}
\hline $\begin{array}{l}\text { Duicio } \\
\text { Numor }\end{array}$ & $\begin{array}{c}\text { standard } \\
\text { (incti) }\end{array}$ & & & $\begin{array}{l}\text { rye } \\
\text { incti) }\end{array}$ & $\begin{array}{l}\text { ree } \\
\text { min? }\end{array}$ & $\begin{array}{l}\text { Wost } \\
\text { inch: }\end{array}$ & $\begin{array}{l}\text { Post } \\
\text { mim }\end{array}$ \\
\hline D) & $\begin{array}{l}\text { तins } \\
.0200\end{array}$ & $\begin{array}{l}\text { gear } \\
\text { gide }\end{array}$ & $\begin{array}{l}\text { Lrrmer } \\
\text { cuter }\end{array}$ & $\begin{array}{l}0.0150 \\
.0150\end{array}$ & $\begin{array}{l}.502 \\
. .9810\end{array}$ & $\begin{array}{r}.0190 \\
=0180\end{array}$ & $\begin{array}{l}0.4520 \\
.4572\end{array}$ \\
\hline & & $\begin{array}{l}\text { plath } \\
\text { side }\end{array}$ & $\begin{array}{l}\text { marer } \\
\text { outer }\end{array}$ & $\begin{array}{l}0.0130 \\
.0140\end{array}$ & $\begin{array}{l}0.302 \\
.3550\end{array}$ & $\begin{array}{r}.0160 \\
.0100\end{array}$ & $\begin{array}{l}.4064 \\
.4572\end{array}$ \\
\hline D) : & & $\begin{array}{l}\text { gear } \\
\text { EjdE }\end{array}$ & $\begin{array}{l}\text { inner } \\
\text { outer }\end{array}$ & $\begin{array}{l}0.000 \\
0.0170\end{array}$ & $\begin{array}{r}.5080 \\
.4318\end{array}$ & $\begin{array}{l}0.0200 \\
0.0170\end{array}$ & $\begin{array}{r}0.5060 \\
0.419\end{array}$ \\
\hline & & $\begin{array}{l}\text { 1ain } \\
\text { side }\end{array}$ & $\begin{array}{l}\text { inner } \\
\text { outer }\end{array}$ & $\begin{array}{l}0.0150 \\
0.090\end{array}$ & $\begin{array}{l}.9810 \\
.457\end{array}$ & $\begin{array}{r}0.00 \\
.0100\end{array}$ & $\begin{array}{r}.3910 \\
.4572\end{array}$ \\
\hline
\end{tabular}




\section{OFIGINAL PAGE IS \\ OF POOR QUALITY}

* Fiear Fotor uil Seal lip width wa

\begin{tabular}{|c|c|c|c|c|c|c|c|c|}
\hline \multicolumn{2}{|c|}{$\begin{array}{l}\text { Build } \\
\text { Number }\end{array}$} & \multicolumn{3}{|l|}{$\begin{array}{l}\text { Standard } \\
\text { (inch) }\end{array}$} & $\begin{array}{l}\text { Fre } \\
\text { (iпci) }\end{array}$ & $\begin{array}{l}\text { Fre } \\
\text { (ma) }\end{array}$ & $\begin{array}{l}\text { Fost } \\
\text { (inch) }\end{array}$ & $\begin{array}{l}\text { Post } \\
(\mathrm{mm})\end{array}$ \\
\hline \multirow[t]{4}{*}{$A$} & 1 & $\max$ & $g e a r^{-}$ & inrier & $N A$ & $N A$ & $\mathrm{NA}$ & NA \\
\hline & & 0.0200 & $s i d e$ & outer & $N A$ & $N A$ & NA & $\mathrm{NA}$ \\
\hline & & & Plain & inner & $N A$ & $N A$ & NA & $N A$ \\
\hline & & & side & outer & $N A$ & $N A$ & $N A$ & $N A$ \\
\hline \multirow[t]{4}{*}{ E) } & $!$ & & gear & inner & 0.0110 & 0.2794 & 0.0210 & 0.5344 \\
\hline & & & side & outer & 0.0100 & 0.2540 & 0.010 & 0.002 \\
\hline & & & p1aiп & i.riner & 0.0160 & 0.4064 & 0.0480 & 1.2192 \\
\hline & & & side & outer & 0.0120 & 0.3048 & 0.0390 & 0.9900 \\
\hline \multirow[t]{4}{*}{$E$} & $i$ & & gear & inrier & 0.0080 & $0.20 x$ & 0.080 & 0.2032 \\
\hline & & & $s i d e$ & outer & .0080 & $0.20 \mathrm{~L}$ & 0.0000 & 0.2052 \\
\hline & & & plair & driner & .0080 & 0.202 & .0080 & 0.2032 \\
\hline & & & side & outer & 0.0080 & 0.202 & 0.0000 & 0.2032 \\
\hline \multirow[t]{4}{*}{ C) } & 2 & & qear & inner & 0.0080 & 0.2022 & 0.0080 & 0.2032 \\
\hline & & & side & outer & 0.0080 & 0.20 .2 & 0.0080 & 0.2032 \\
\hline & & & plain & inner & 0.0080 & 0.2032 & 0.0080 & 0.2032 \\
\hline & & & side & outer & 0.0080 & 0.2052 & 0.0080 & 0.2052 \\
\hline \multirow[t]{4}{*}{$C$} & $\because$ & & gear & inner & 0.0080 & 0.2032 & 0.0130 & 0.5302 \\
\hline & & & side & outer & 0.0080 & 0.2 .2 & 0.0130 & 0.5002 \\
\hline & & & plain & inner & 0.0080 & 0.2052 & 0.0120 & 0.3048 \\
\hline & & & side & outer & 0.0000 & 0.20 .2 & 0.0140 & 0.5556 \\
\hline \multirow[t]{4}{*}{ C) } & 4 & & gear & inner & 0.0110 & 0.2774 & 0.0160 & 0.4064 \\
\hline & & & side & outer & 0.0110 & 0.2794 & 0.0160 & 0.4064 \\
\hline & & & plain & inner & 0.0100 & 0.2540 & 0.0130 & 0.3 .302 \\
\hline & & & side & outer- & 0.0100 & 0.2540 & 0.0130 & 0.3302 \\
\hline \multirow[t]{4}{*}{ D) } & 1 & & gear & inner & 0.0130 & 0.3502 & 0.0160 & 0.4064 \\
\hline & & & side & outer & 0.0120 & 0.3048 & 0.0160 & 0.4064 \\
\hline & & & plain & inner & 0.0150 & 0.5810 & 0.0130 & 0.5302 \\
\hline & & & side & outer & 0.0100 & 0.2540 & 0.0150 & 0.5302 \\
\hline \multirow[t]{4}{*}{ D) } & 2 & & gear & inner & 0.0160 & 0.4064 & 0.0160 & 0.4064 \\
\hline & & & side & outer & 0.0100 & 0.2540 & 0.0110 & 0.2794 \\
\hline & & & plain & inner & 0.0150 & $0 . .810$ & 0.0100 & 0.2540 \\
\hline & & & side & outer & 0.0160 & 0.4034 & 0.0160 & 0.4064 \\
\hline
\end{tabular}


ORIOHA: FAOE is

OF POOK QUALITY

* Rear Rotor dil Seal Lip Width **

\begin{tabular}{|c|c|c|c|c|c|c|c|}
\hline $\begin{array}{l}\text { Build } \\
\text { Number }\end{array}$ & $\begin{array}{c}\text { Standard } \\
\text { (inch) }\end{array}$ & & & $\begin{array}{l}\text { Pre } \\
\text { (inch) }\end{array}$ & $\begin{array}{l}\text { Pre } \\
(\mathrm{mm})\end{array}$ & $\begin{array}{l}\text { Post } \\
\text { (inch) }\end{array}$ & $\begin{array}{l}\text { Post } \\
(\mathrm{mm})\end{array}$ \\
\hline D) 3 & $\begin{array}{l}\max \\
0.0200\end{array}$ & $\begin{array}{l}\text { gear } \\
\text { side }\end{array}$ & $\begin{array}{l}\text { inner } \\
\text { outer }\end{array}$ & $\begin{array}{l}0.0090 \\
0.0110\end{array}$ & $\begin{array}{l}0.2286 \\
0.2794\end{array}$ & $\begin{array}{l}0.0090 \\
0.0120\end{array}$ & $\begin{array}{l}0.2286 \\
0.3048\end{array}$ \\
\hline & & $\begin{array}{l}\text { Plain } \\
\text { side }\end{array}$ & $\begin{array}{l}\text { inner } \\
\text { outer }\end{array}$ & $\begin{array}{l}0.0100 \\
0.0160\end{array}$ & $\begin{array}{l}0.2540 \\
0.4064\end{array}$ & $\begin{array}{l}0.0130 \\
0.0180\end{array}$ & $\begin{array}{l}0.3302 \\
0.4572\end{array}$ \\
\hline D) 4 & & $\begin{array}{l}\text { gear } \\
\text { side }\end{array}$ & $\begin{array}{l}\text { inner } \\
\text { outer }\end{array}$ & $\begin{array}{l}0.0090 \\
0.0120\end{array}$ & $\begin{array}{l}0.2286 \\
0.3048\end{array}$ & $\begin{array}{l}0.0100 \\
0.0120\end{array}$ & $\begin{array}{l}0.2540 \\
0.3048\end{array}$ \\
\hline & & $\begin{array}{l}\text { plain } \\
\text { side }\end{array}$ & $\begin{array}{l}\text { inner } \\
\text { outer }\end{array}$ & $\begin{array}{l}0.0120 \\
0.0180\end{array}$ & $\begin{array}{l}0.3048 \\
0.4572\end{array}$ & $\begin{array}{l}0.0120 \\
0.0180\end{array}$ & $\begin{array}{l}0.3048 \\
0.4572\end{array}$ \\
\hline
\end{tabular}




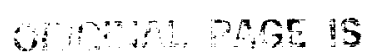

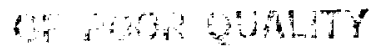

* Front Fotor Aper Seal. Clearance

\begin{tabular}{|c|c|c|c|c|c|c|c|c|}
\hline $\begin{array}{l}\text { But } \\
\text { Numb }\end{array}$ & $1 \mathrm{de}$ & $\begin{array}{l}\text { Standard } \\
\text { olearance } \\
\text { (inch) }\end{array}$ & & $\begin{array}{l}\text { wre } \\
\text { anchi }\end{array}$ & $\begin{array}{l}\text { Fre } \\
\text { (mini })\end{array}$ & & $\begin{array}{l}\text { Fost } \\
\text { (inch) }\end{array}$ & $\begin{array}{l}\text { Fost } \\
\sin m\end{array}$ \\
\hline$A$ ) & 1 & $\begin{array}{l}.0024 \\
t 0 \\
.0040\end{array}$ & $\begin{array}{l}\text { A) } \\
\text { E) } \\
\text { C) }\end{array}$ & $\begin{array}{l}0.0030 \\
.0030 \\
0.0030\end{array}$ & $\begin{array}{l}10762 \\
0.0762 \\
0.0762\end{array}$ & $\begin{array}{l}\text { a) } \\
\text { B) } \\
\text { E) }\end{array}$ & $\begin{array}{l}0.0000 \\
.00 \mathrm{0} \\
.0000\end{array}$ & $\begin{array}{r}.0762 \\
0.0762 \\
0.0762\end{array}$ \\
\hline B) & 1 & & $\begin{array}{l}\text { A) } \\
\text { B) } \\
\text { C) }\end{array}$ & $\begin{array}{l}0.0030 \\
0.0030 \\
0.0050\end{array}$ & $\begin{array}{l}0.0762 \\
0.0762 \\
0.0762\end{array}$ & $\begin{array}{l}\text { A) } \\
\text { B) } \\
\text { C) }\end{array}$ & $\begin{array}{l}0.0030 \\
0.0030 \\
.0050\end{array}$ & $\begin{array}{l}0.0762 \\
0.0762 \\
0.0762\end{array}$ \\
\hline C) & 1 & & $\begin{array}{l}\text { A) } \\
\text { B) } \\
\text { C) }\end{array}$ & $\begin{array}{l}0.0030 \\
0.0000 \\
0.0030\end{array}$ & $\begin{array}{l}0.0762 \\
0.0762 \\
0.0762\end{array}$ & $\begin{array}{l}\text { A) } \\
\text { B) } \\
\text { C) }\end{array}$ & $\begin{array}{l}0.0030 \\
0.0030 \\
0.0030\end{array}$ & $\begin{array}{l}0.0762 \\
0.0762 \\
0.0762\end{array}$ \\
\hline E) & 2 & & $\begin{array}{l}\text { A) } \\
\text { E) } \\
\text { C) }\end{array}$ & $\begin{array}{l}0.0050 \\
.0000 \\
.0050\end{array}$ & $\begin{array}{l}0.0762 \\
0.0762 \\
0.0762\end{array}$ & $\begin{array}{l}a) \\
b) \\
\text { c) }\end{array}$ & $\begin{array}{l}0.0030 \\
0.0000 \\
0.0000\end{array}$ & $\begin{array}{l}0.0762 \\
0.0762 \\
0.0762\end{array}$ \\
\hline$C)$ & 3 & & $\begin{array}{l}\text { A) } \\
\text { E) } \\
\text { C) }\end{array}$ & $\begin{array}{l}0.0030 \\
0.0030 \\
.0030\end{array}$ & $\begin{array}{l}0.0762 \\
0.0762 \\
0.0762\end{array}$ & $\begin{array}{l}A) \\
B) \\
C)\end{array}$ & $\begin{array}{l}0.0050 \\
0.0000 \\
0.0000\end{array}$ & $\begin{array}{l}0.0762 \\
0.0762 \\
0.0762\end{array}$ \\
\hline C) & 4 & & $\begin{array}{l}\text { A) } \\
\text { B) } \\
\text { C) }\end{array}$ & $\begin{array}{l}0.0030 \\
0.0030 \\
0.0030\end{array}$ & $\begin{array}{l}0.0762 \\
0.0762 \\
0.0762\end{array}$ & $\begin{array}{l}\text { A) } \\
\text { E) } \\
\text { C) }\end{array}$ & $\begin{array}{l}0.0030 \\
0.0030 \\
0.0030\end{array}$ & $\begin{array}{l}0.0762 \\
0.0762 \\
0.0762\end{array}$ \\
\hline D) & 1 & & $\begin{array}{l}\text { A) } \\
\text { B) } \\
\text { C) }\end{array}$ & $\begin{array}{l}0.0030 \\
0.0030 \\
0.0030\end{array}$ & $\begin{array}{l}0.0762 \\
0.0762 \\
0.0762\end{array}$ & $\begin{array}{l}\text { A) } \\
\text { B) } \\
\text { C) }\end{array}$ & $\begin{array}{l}0.0030 \\
0.0050 \\
0.0030\end{array}$ & $\begin{array}{l}0.0762 \\
0.0762 \\
0.0762\end{array}$ \\
\hline D) & 2 & & $\begin{array}{l}\text { A) } \\
\text { B) } \\
\text { C) }\end{array}$ & $\begin{array}{l}0.0030 \\
0.0030 \\
0.0030\end{array}$ & $\begin{array}{l}0.0762 \\
0.0762 \\
0.0762\end{array}$ & $\begin{array}{l}\text { A) } \\
\text { B) } \\
\text { C) }\end{array}$ & $\begin{array}{l}0.0030 \\
0.0030 \\
0.0030\end{array}$ & $\begin{array}{l}0.0762 \\
0.0762 \\
0.0762\end{array}$ \\
\hline D) & 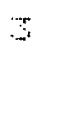 & & $\begin{array}{l}\text { A) } \\
\text { B) } \\
\text { C) }\end{array}$ & $\begin{array}{l}0.0030 \\
0.0050 \\
0.0030\end{array}$ & $\begin{array}{l}0.0762 \\
0.0762 \\
0.0762\end{array}$ & $\begin{array}{l}\text { A) } \\
\text { E) } \\
\text { C) }\end{array}$ & $\begin{array}{l}0.0030 \\
0.0030 \\
0.0030\end{array}$ & $\begin{array}{l}0.0762 \\
0.0762 \\
0.0762\end{array}$ \\
\hline D) & 4 & & $\begin{array}{l}\text { A) } \\
\text { B) } \\
\text { C) }\end{array}$ & $\begin{array}{l}0.0030 \\
0.0030 \\
0.0030\end{array}$ & $\begin{array}{l}0.0762 \\
0.0762 \\
0.0762\end{array}$ & $\begin{array}{l}\text { A) } \\
\text { B) } \\
\text { C) }\end{array}$ & $\begin{array}{l}0.0050 \\
0.0050 \\
0.0050\end{array}$ & $\begin{array}{l}0.0762 \\
0.0762 \\
0.0762\end{array}$ \\
\hline
\end{tabular}




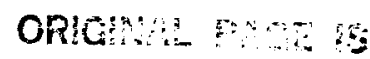

of PCOn quatir

a Front fotor mpex geal Melght

\begin{tabular}{|c|c|c|c|c|c|c|c|c|}
\hline $\begin{array}{l}\text { Buta. } \\
\text { Numie }\end{array}$ & 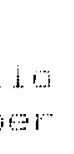 & $\begin{array}{l}\text { tendard } \\
\text { Heidtht } \\
\text { (non) }\end{array}$ & & $\begin{array}{l}\text { Pre } \\
\text { (2noh) }\end{array}$ & $\begin{array}{l}\text { wre } \\
\text { (inin })\end{array}$ & & $\begin{array}{l}\text { Post } \\
\text { inchi }\end{array}$ & $\begin{array}{c}P o \equiv t \\
(\mathrm{~mm})\end{array}$ \\
\hline$(m)$ & i & $\begin{array}{l}n \perp n \\
0.21 . . .\end{array}$ & $\begin{array}{l}\text { i) } \\
\mathrm{b}) \\
\mathrm{c})\end{array}$ & $\begin{array}{r}.50 \\
.50 \\
.20\end{array}$ & $\begin{array}{r}0.4592 \\
9.4320 \\
.4502\end{array}$ & $\begin{array}{l}a j \\
3 i \\
\cdots\end{array}$ & $\begin{array}{r}x+10 \\
-350 \\
-3520\end{array}$ & $\begin{array}{l}5.4 \% 8 \\
8.4 .28 \\
9.4 .29\end{array}$ \\
\hline $\mathrm{Bi}$ & 1 & & $\begin{array}{l}a \\
0 \\
0 \\
\cdots\end{array}$ & $\begin{array}{r}.30 \\
.320 \\
-320\end{array}$ & $\begin{array}{l}3.4074 \\
3.4228 \\
6.4228\end{array}$ & $\begin{array}{l}\text { A) } \\
B ! \\
\text { ) }\end{array}$ & $\begin{array}{r}.00 \\
.510 \\
-310\end{array}$ & $\begin{array}{r}0.92 \\
9.4074 \\
6.40 \% 4\end{array}$ \\
\hline 0 & 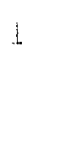 & & $\begin{array}{l}a j \\
b) \\
b i\end{array}$ & $\begin{array}{r}x+10 \\
-3=0 \\
-320\end{array}$ & $\begin{array}{l}9.4074 \\
9.4 .28 \\
9.4 .26\end{array}$ & $\begin{array}{l}\text { A) } \\
\text { B) } \\
\text { C) }\end{array}$ & $\begin{array}{r}010 \\
-50 \\
-20\end{array}$ & $\begin{array}{l}0.4074 \\
6.4 .28 \\
0.4228\end{array}$ \\
\hline$\omega$ & $\ldots$ & & $\begin{array}{l}a \\
B) \\
i\end{array}$ & $\begin{array}{r}0.25 \\
0.15 \\
0.315\end{array}$ & $\begin{array}{l}9.15 \\
\because \quad 0.15 \\
6.315\end{array}$ & $\begin{array}{l}\mathrm{A} \\
\mathrm{B} \\
\mathrm{i}\end{array}$ & $\begin{array}{r}0.315 \\
0.315 \\
0.315\end{array}$ & $\begin{array}{r}0.55 \\
915 \\
9.515\end{array}$ \\
\hline $\mathrm{C}$ & $\because$ & & $\begin{array}{l}A) \\
b) \\
c)\end{array}$ & $\begin{array}{r}0.15 \\
0.015 \\
00.215\end{array}$ & 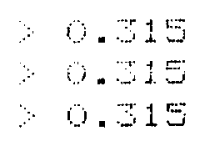 & $\begin{array}{l}A \\
B \\
C\end{array}$ & $\begin{array}{r}0.315 \\
0.315 \\
0.315\end{array}$ & $\begin{array}{r}0.315 \\
0.315 \\
0.015\end{array}$ \\
\hline C) & a & & $\begin{array}{l}\text { A } \\
\mathrm{B}) \\
\mathrm{C}\end{array}$ & $\begin{array}{r}0.315 \\
0.315 \\
0.315\end{array}$ & $\begin{array}{l}0.315 \\
0.515 \\
0 . \pm 15\end{array}$ & $\begin{array}{l}\text { A) } \\
\text { B) } \\
\text { C) }\end{array}$ & $\begin{array}{l}0.315 \\
0.315 \\
0.315\end{array}$ & $\begin{array}{l}0.315 \\
0.315 \\
0.315\end{array}$ \\
\hline D) & \pm & & $\begin{array}{l}A) \\
B> \\
C\end{array}$ & $\begin{array}{r}0.25 \\
0.25 \\
0.215\end{array}$ & $\begin{array}{l}0.315 \\
0.15 \\
0.315\end{array}$ & $\begin{array}{l}\text { A) } \\
\text { E) } \\
\text { C) }\end{array}$ & $\begin{array}{r}0.315 \\
0.315 \\
0.215\end{array}$ & $\begin{array}{r}0.315 \\
0.315 \\
0.315\end{array}$ \\
\hline D) & 2 & & $\begin{array}{l}A) \\
B) \\
B)\end{array}$ & $\begin{array}{r}0.35 \\
0.315 \\
0.315\end{array}$ & $\begin{array}{ll}0 & 0.55 \\
0 & 0.515 \\
3 & 0.315\end{array}$ & $\begin{array}{l}\text { A) } \\
\text { E) } \\
\text { C) }\end{array}$ & $\begin{array}{r}0.215 \\
0.215 \\
0.315\end{array}$ & $\begin{array}{r}0.315 \\
0.315 \\
0.315\end{array}$ \\
\hline D) & 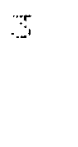 & & $\begin{array}{l}\text { A) } \\
B) \\
\text { C) }\end{array}$ & $\begin{array}{ll}0 & 0.15 \\
\ddots & 0 . \pm 15 \\
\ddots & 0.715\end{array}$ & $\begin{array}{ll}0 & 0.315 \\
y & 0.515 \\
\gamma & 0.315\end{array}$ & $\begin{array}{l}\text { A) } \\
\text { B) } \\
\text { C) }\end{array}$ & $\begin{array}{l}0.315 \\
0.315 \\
0.315\end{array}$ & $\begin{array}{l}0.315 \\
0.315 \\
0.315\end{array}$ \\
\hline D) & 4 & & $\begin{array}{l}\text { A) } \\
\text { B) } \\
\text { C) }\end{array}$ & $\begin{array}{l}0.315 \\
0.315 \\
0.315\end{array}$ & $\begin{array}{ll}0 & 015 \\
0 & 0.315 \\
0 & 0.515\end{array}$ & $\begin{array}{l}\text { A) } \\
\text { B) } \\
\text { C) }\end{array}$ & $\begin{array}{l}0.315 \\
0.315 \\
0.315\end{array}$ & $\begin{array}{l}0.315 \\
0.315 \\
0.315\end{array}$ \\
\hline
\end{tabular}


ORIGINA:

OF POOF OP:

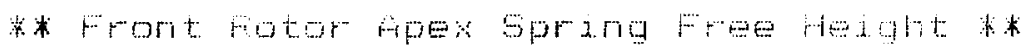

\begin{tabular}{|c|c|c|c|c|c|c|c|c|}
\hline $\begin{array}{l}\text { But } \\
\text { numb }\end{array}$ & id & 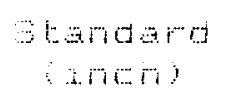 & & $\begin{array}{l}\text { Fes } \\
\text { zrem }\end{array}$ & $\begin{array}{l}F \in \\
\therefore m i n\end{array}$ & & $\begin{array}{l}\text { Fost } \\
\text { Ancti }\end{array}$ & $\begin{array}{l}\text { Fost } \\
\text { mini }\end{array}$ \\
\hline की & & $\begin{array}{c}m 2 n \\
.1910\end{array}$ & $\begin{array}{l}3 \\
6 \\
3\end{array}$ & $\begin{array}{r}2100 \\
.2150 \\
2180\end{array}$ & $\begin{array}{l}5.4610 \\
.4610 \\
.4 x\end{array}$ & $\begin{array}{l}\mathrm{a}) \\
\mathrm{g} \\
\mathrm{y}\end{array}$ & $\begin{array}{r}2190 \\
.2160 \\
.2180\end{array}$ & $\begin{array}{l}5.600 \\
5.4064 \\
5.507\end{array}$ \\
\hline$b)$ & 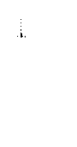 & & $\begin{array}{l}\text { a) } \\
\text { E) } \\
\text { C) }\end{array}$ & $\begin{array}{l}2190 \\
2160 \\
.2160\end{array}$ & $\begin{array}{l}5020 \\
5.4064 \\
5.527\end{array}$ & $\begin{array}{l}\text { i) } \\
\mathrm{B} \\
\mathrm{b}\end{array}$ & $\begin{array}{r}2150 \\
.2100 \\
.2100\end{array}$ & $\begin{array}{l}5.4610 \\
5.4102 \\
5.450\end{array}$ \\
\hline c) & $i$ & & $\begin{array}{l}H i \\
B i \\
B\end{array}$ & $\begin{array}{l}.2150 \\
.2150 \\
.2100\end{array}$ & $\begin{array}{l}5.4610 \\
5.4102 \\
5.40\end{array}$ & $\begin{array}{l}a) \\
B) \\
b\end{array}$ & $\begin{array}{l}0.2150 \\
0.21 .50 \\
.2100\end{array}$ & $\begin{array}{l}5.4610 \\
5.4100 \\
-4.40\end{array}$ \\
\hline $\mathrm{c}$ & $a$ & & $\begin{array}{l}\mathrm{H} \\
\vdots \\
\mathrm{C}\end{array}$ & $\begin{array}{r}0.181 \\
.191 \\
0.181\end{array}$ & $\begin{array}{r}0.131 \\
.161 \\
.161\end{array}$ & $\begin{array}{l}A) \\
\theta) \\
C\end{array}$ & $\begin{array}{r}0.191 \\
. .191 \\
. .191\end{array}$ & $\begin{array}{r}0.101 \\
0.191 \\
.191\end{array}$ \\
\hline$\ldots$ & & & $\begin{array}{l}\text { A) } \\
\text { E) } \\
\text { ) }\end{array}$ & $\begin{array}{r}0.181 \\
0.181 \\
.191\end{array}$ & $\begin{array}{r}.191 \\
0.191 \\
0.191\end{array}$ & $\begin{array}{l}\text { b) } \\
B> \\
C\end{array}$ & $\begin{array}{r}.191 \\
0.181 \\
. \\
.191\end{array}$ & $\begin{array}{l}\because .181 \\
0 \quad 0.131 \\
0.161\end{array}$ \\
\hline $\mathrm{C}$ & 4 & & $\begin{array}{l}\text { A) } \\
\text { B) } \\
\text { C) }\end{array}$ & $\begin{array}{r}0.181 \\
.181 \\
.181\end{array}$ & $\begin{array}{l}0.131 \\
0.131 \\
0.131\end{array}$ & $\begin{array}{l}\text { A) } \\
B i \\
B i\end{array}$ & $\begin{array}{r}0.191 \\
0.191 \\
0.191\end{array}$ & $\begin{array}{ll} & 0.191 \\
\ddots & 0.181 \\
\ddots & 0.181\end{array}$ \\
\hline bi & 1 & & $\begin{array}{l}A) \\
B ; \\
C ;\end{array}$ & $\begin{array}{r}0.191 \\
0.191 \\
0.191\end{array}$ & $\begin{array}{r}0.191 \\
0.181 \\
0.181\end{array}$ & $\begin{array}{l}\text { A) } \\
B) \\
(i)\end{array}$ & $\begin{array}{l}0.181 \\
0.181 \\
0.181\end{array}$ & $\begin{array}{rr}0.181 \\
0.18 t \\
0.181\end{array}$ \\
\hline$D j$ & $\therefore$ & & $\begin{array}{l}(A) \\
B) \\
C)\end{array}$ & $\begin{array}{r}0.191 \\
0.181 \\
0.191\end{array}$ & $\begin{array}{r}0.101 \\
0.181 \\
0.181\end{array}$ & $\begin{array}{l}\text { A) } \\
\text { B) } \\
\text { C) }\end{array}$ & $\begin{array}{r}0.131 \\
0.131 \\
0.131\end{array}$ & $\begin{array}{rr}0.191 \\
0.181 \\
0.191\end{array}$ \\
\hline 0 & $\Xi$ & & $\begin{array}{l}A) \\
B\rangle \\
C)\end{array}$ & $\begin{array}{r}0.131 \\
0.191 \\
0.181\end{array}$ & $\begin{array}{l}0.191 \\
0.181 \\
0.181\end{array}$ & $\begin{array}{l}\text { A) } \\
\text { B) } \\
\text { C) }\end{array}$ & $\begin{array}{r}0.181 \\
0.181 \\
0.191\end{array}$ & $\begin{array}{l}0.181 \\
0.181 \\
0.181\end{array}$ \\
\hline D) & 4 & & $\begin{array}{l}\text { A) } \\
\text { E) } \\
\text { C) }\end{array}$ & $\begin{array}{l}0.181 \\
0.181 \\
0.181\end{array}$ & $\begin{array}{l}0.181 \\
0.181 \\
0.181\end{array}$ & $\begin{array}{l}\text { A) } \\
\text { B) } \\
\text { C) }\end{array}$ & $\begin{array}{l}0.181 \\
0.181 \\
0.181\end{array}$ & $\begin{array}{l}0.181 \\
0.181 \\
0.181\end{array}$ \\
\hline
\end{tabular}


OH:

OF $\mathrm{Fe}$

a Font Fotor Aper Seal Weight w

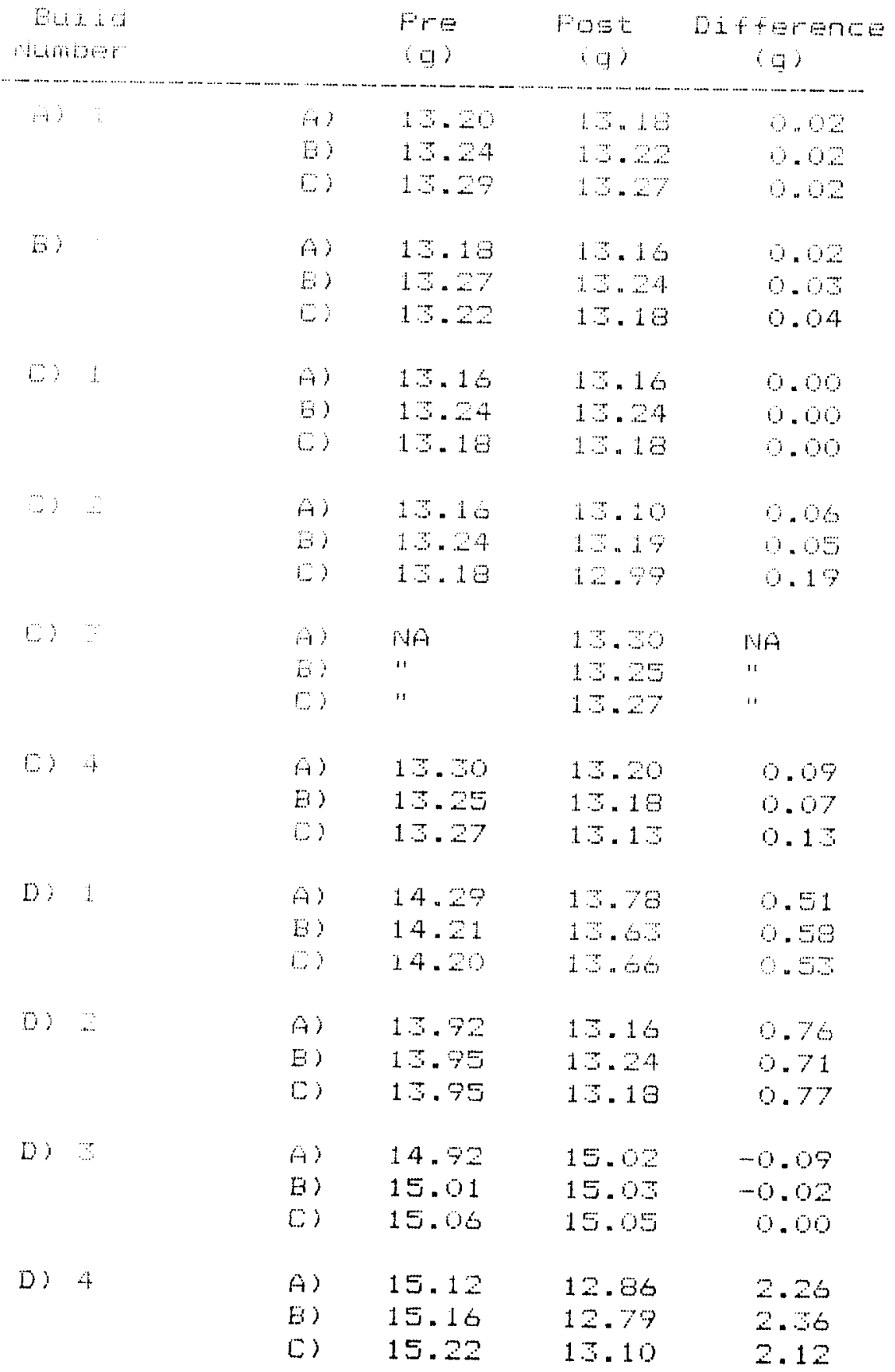


Oritein:

DF PODE C....

* Fear Fotor Apen Geal Clearance

\begin{tabular}{|c|c|c|c|c|c|c|c|c|}
\hline $\begin{array}{r}\text { Bui } \\
\text { Nuint }\end{array}$ & $\begin{array}{l}1 \mathrm{~d} \\
\mathrm{er}\end{array}$ & $\begin{array}{l}\text { Standard } \\
\text { olearance } \\
\text { (incti) }\end{array}$ & & $\begin{array}{l}\text { Fre } \\
\text { (inch) }\end{array}$ & $\begin{array}{l}\text { Fre } \\
\text { (min) }\end{array}$ & & $\begin{array}{l}\text { Fost } \\
(i n c h)\end{array}$ & $\begin{array}{l}\text { Fost: } \\
\text { (inim) }\end{array}$ \\
\hline A) & 1. & $\begin{array}{l}0.0094 \\
+0 \\
.0040\end{array}$ & $\begin{array}{l}\text { A) } \\
\text { E) } \\
\text { C) }\end{array}$ & $\begin{array}{l}.0030 \\
.0030 \\
.0030\end{array}$ & $\begin{array}{l}0.0762 \\
0.0762 \\
0.0762\end{array}$ & $\begin{array}{l}\text { A) } \\
\text { B) } \\
\text { C) }\end{array}$ & $\begin{array}{l}0.0030 \\
0.0030 \\
0.0030\end{array}$ & $\begin{array}{l}0.0762 \\
0.0762 \\
0.0762\end{array}$ \\
\hline B) & $i$ & & $\begin{array}{l}A> \\
B> \\
C\end{array}$ & $\begin{array}{l}0.0030 \\
0.0030 \\
0.0030\end{array}$ & $\begin{array}{l}0.0762 \\
0.0762 \\
0.0762\end{array}$ & $\begin{array}{l}A \text { ) } \\
\text { E) } \\
\text { C) }\end{array}$ & $\begin{array}{l}0.0030 \\
0.0030 \\
0.0050\end{array}$ & $\begin{array}{l}0.0762 \\
0.0762 \\
0.0762\end{array}$ \\
\hline C) & 1 & & $\begin{array}{l}\text { A) } \\
\text { B) } \\
\text { C? }\end{array}$ & $\begin{array}{l}0.0030 \\
0.0030 \\
0.0030\end{array}$ & $\begin{array}{l}0.0702 \\
0.0762 \\
0.0762\end{array}$ & $\begin{array}{l}\text { A) } \\
\text { B) } \\
\text { C) }\end{array}$ & $\begin{array}{l}0.0030 \\
.0030 \\
.0030\end{array}$ & $\begin{array}{l}0.0762 \\
0.0762 \\
0.0762\end{array}$ \\
\hline$\infty$ & $\therefore$ & & $\begin{array}{l}\text { A) } \\
\text { B) } \\
\text { C) }\end{array}$ & $\begin{array}{r}0.0030 \\
0.0050 \\
.0050\end{array}$ & $\begin{array}{l}0.0762 \\
0.0762 \\
0.0762\end{array}$ & $\begin{array}{l}\text { A) } \\
\text { B) } \\
\text { C) }\end{array}$ & $\begin{array}{l}0.0050 \\
0.0000 \\
.0050\end{array}$ & $\begin{array}{l}0.0762 \\
0.0762 \\
0.0762\end{array}$ \\
\hline $\mathrm{c}$ & $x$ & & $\begin{array}{l}\text { A) } \\
\text { B) } \\
\text { C) }\end{array}$ & $\begin{array}{l}0.0030 \\
0.0030 \\
0.0030\end{array}$ & $\begin{array}{l}0.0762 \\
0.0762 \\
0.0762\end{array}$ & $\begin{array}{l}\text { A) } \\
\text { E) } \\
\text { C) }\end{array}$ & $\begin{array}{l}0.0030 \\
0.0030 \\
.0030\end{array}$ & $\begin{array}{l}0.0762 \\
0.0762 \\
0.0702\end{array}$ \\
\hline C) & 4 & & $\begin{array}{l}\text { A) } \\
\text { B) } \\
\text { C) }\end{array}$ & $\begin{array}{l}0.0050 \\
0.0050 \\
0.0030\end{array}$ & $\begin{array}{l}0.0762 \\
0.0762 \\
0.0762\end{array}$ & $\begin{array}{l}\text { A) } \\
\text { B) } \\
\text { C) }\end{array}$ & $\begin{array}{l}0.0030 \\
0.0030 \\
0.0030\end{array}$ & $\begin{array}{l}0.0762 \\
0.0762 \\
0.0762\end{array}$ \\
\hline D) & 1 & & $\begin{array}{l}\text { A) } \\
\text { B) } \\
\text { C) }\end{array}$ & $\begin{array}{l}0.0030 \\
0.0030 \\
0.0030\end{array}$ & $\begin{array}{l}0.0762 \\
0.0762 \\
0.0762\end{array}$ & $\begin{array}{l}\text { A) } \\
\text { B) } \\
\text { C) }\end{array}$ & $\begin{array}{l}0.0030 \\
0.0030 \\
0.0030\end{array}$ & $\begin{array}{l}0.0762 \\
0.0762 \\
0.0762\end{array}$ \\
\hline D) & 2 & & $\begin{array}{l}\text { A) } \\
\text { B) } \\
\text { C) }\end{array}$ & $\begin{array}{l}0.0030 \\
0.0030 \\
0.0030\end{array}$ & $\begin{array}{l}0.0762 \\
0.0762 \\
0.0762\end{array}$ & $\begin{array}{l}\text { A) } \\
\text { B) } \\
\text { C) }\end{array}$ & $\begin{array}{l}0.0030 \\
0.0030 \\
0.0030\end{array}$ & $\begin{array}{l}0.0762 \\
0.0762 \\
0.0762\end{array}$ \\
\hline D) & $\Xi$ & & $\begin{array}{l}\text { A) } \\
\text { E) } \\
\text { C) }\end{array}$ & $\begin{array}{l}0.0030 \\
0.0030 \\
0.0030\end{array}$ & $\begin{array}{l}0.0762 \\
0.0762 \\
0.0762\end{array}$ & $\begin{array}{l}\text { A) } \\
\text { B) } \\
\text { C) }\end{array}$ & $\begin{array}{l}0.0030 \\
0.0030 \\
0.0030\end{array}$ & $\begin{array}{l}0.0762 \\
0.0762 \\
0.0762\end{array}$ \\
\hline D) & 4 & & $\begin{array}{l}\text { A) } \\
\text { B) } \\
\text { C) }\end{array}$ & $\begin{array}{l}0.0030 \\
0.0030 \\
0.0030\end{array}$ & $\begin{array}{l}0.0762 \\
0.0762 \\
0.0762\end{array}$ & $\begin{array}{l}\text { A) } \\
\text { B) } \\
\text { C) }\end{array}$ & $\begin{array}{l}0.0030 \\
0.0030 \\
0.0050\end{array}$ & $\begin{array}{l}0.0762 \\
0.0762 \\
0.0762\end{array}$ \\
\hline
\end{tabular}


ORIGIAR
OF POOR Qusini

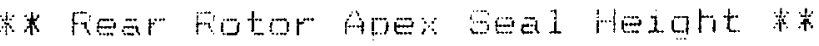

\begin{tabular}{|c|c|c|c|c|c|c|c|c|}
\hline $\begin{array}{l}\text { Buid } \\
\text { Numb }\end{array}$ & id & $\begin{array}{l}\text { tandard } \\
\text { Heignt } \\
\text { inchi }\end{array}$ & & $\begin{array}{l}\text { ree } \\
(2 n e t)\end{array}$ & $\begin{array}{l}F(m e \\
(\text { initis })\end{array}$ & & $\begin{array}{l}\text { Fost } \\
\text { inch) }\end{array}$ & $\begin{array}{l}\text { Fost } \\
\text { inn: }\end{array}$ \\
\hline$\theta$ & 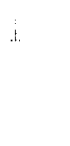 & ) & $\begin{array}{l}A) \\
B \\
0\end{array}$ & 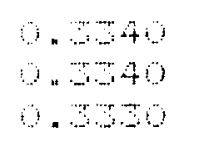 & $\begin{array}{l}.4830 \\
.4630 \\
.4582\end{array}$ & $\begin{array}{l}\text { i } \\
\mathrm{B} \\
\mathrm{C})\end{array}$ & $\begin{array}{r}.320 \\
0.920 \\
.230\end{array}$ & 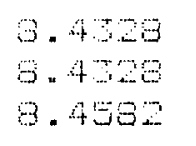 \\
\hline E) & $\vdots$ & & $\begin{array}{l}6 ! \\
6) \\
6 !\end{array}$ & $\begin{array}{r}-20 \\
.520 \\
.530\end{array}$ & $\begin{array}{l}0.428 \\
9.428 \\
9.4582\end{array}$ & $\begin{array}{l}\infty \\
\mathrm{B} \\
\mathrm{C}\end{array}$ & $\begin{array}{r}9300 \\
-510 \\
.300\end{array}$ & $\begin{array}{l}9.3820 \\
8.4074 \\
8.5200\end{array}$ \\
\hline$C ;$ & 1 & & $\begin{array}{l}A) \\
E) \\
C ;\end{array}$ & $\begin{array}{r}0.500 \\
.510 \\
.500\end{array}$ & $\begin{array}{l}9.5320 \\
3.40 \% 4 \\
3.5820\end{array}$ & $\begin{array}{l}A) \\
B) \\
B\end{array}$ & $\begin{array}{r}.3300 \\
.310 \\
0.300\end{array}$ & $\begin{array}{l}3.8320 \\
8.4074 \\
3 . .820\end{array}$ \\
\hline C. & 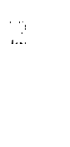 & & $\begin{array}{l}\text { a) } \\
b ; \\
6 ;\end{array}$ & $\begin{array}{r}0.25 \\
0.25 \\
0.15\end{array}$ & 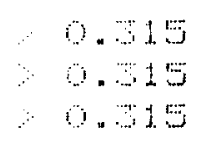 & $\begin{array}{l}\text { a) } \\
\mathrm{B}) \\
6\end{array}$ & $\begin{array}{r}0.15 \\
0.215 \\
0.15\end{array}$ & $\begin{array}{r}9.15 \\
6.015 \\
6.15\end{array}$ \\
\hline$\omega$ & 8 & & $\begin{array}{l}A j \\
B) \\
C\end{array}$ & $\begin{array}{r}1.55 \\
0.515 \\
0.515\end{array}$ & $\begin{array}{l}0.015 \\
6 \quad 0.15 \\
6 \quad 0.515\end{array}$ & $\begin{array}{l}\text { A) } \\
B) \\
C)\end{array}$ & $\begin{array}{r}0.215 \\
0.315 \\
0.015\end{array}$ & $\begin{array}{r}0.515 \\
0.315 \\
0.015\end{array}$ \\
\hline (C) & 4 & & $\begin{array}{l}A) \\
B) \\
B\end{array}$ & $\begin{array}{l}0.315 \\
0.315 \\
0.315\end{array}$ & $\begin{array}{l}9.315 \\
\ddots \quad 0.315 \\
\ddots \quad 015\end{array}$ & $\begin{array}{l}\text { A) } \\
\text { B) } \\
\text { C) }\end{array}$ & $\begin{array}{l}0.35 \\
0.315 \\
0.315\end{array}$ & $\begin{array}{l}0.315 \\
0.315 \\
0.315\end{array}$ \\
\hline D) & $\therefore$ & & $\begin{array}{l}\text { A) } \\
\text { B) } \\
\text { C) }\end{array}$ & $\begin{array}{l}0.35 \\
0.05 \\
0.515\end{array}$ & $\begin{array}{l}0.315 \\
0 \quad 015 \\
0.515\end{array}$ & $\begin{array}{l}\text { A) } \\
8 ; \\
0\end{array}$ & $\begin{array}{r}0.315 \\
0.15 \\
0.315\end{array}$ & $\begin{array}{r}0.315 \\
0.315 \\
0.315\end{array}$ \\
\hline D) & $\because$ & & $\begin{array}{l}\text { A) } \\
\text { B) } \\
\text { C) }\end{array}$ & $\begin{array}{l}0.315 \\
0.315 \\
0.315\end{array}$ & $\begin{array}{l}0.15 \\
6 \quad 0.15 \\
0.15\end{array}$ & $\begin{array}{l}\text { A) } \\
\text { E? } \\
\text { C) }\end{array}$ & $\begin{array}{l}0.515 \\
0.315 \\
0.315\end{array}$ & $\begin{array}{r}0.315 \\
0.315 \\
0.315\end{array}$ \\
\hline$D)$ & 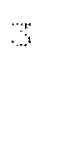 & & $\begin{array}{l}\text { A) } \\
\text { B) } \\
\text { C) }\end{array}$ & $\begin{array}{ll}0.315 \\
\ddots & 0.515 \\
0 & 0.515\end{array}$ & $\begin{array}{l}0.515 \\
0 \quad 0.315 \\
0.315\end{array}$ & $\begin{array}{l}A) \\
\text { E) } \\
\text { C) }\end{array}$ & $\begin{array}{l}0.315 \\
0.315 \\
0.315\end{array}$ & $\begin{array}{l}0.315 \\
0.315 \\
0.315\end{array}$ \\
\hline D) & 4 & & $\begin{array}{l}\text { A) } \\
\text { B) } \\
\text { C) }\end{array}$ & $\begin{array}{l}0.315 \\
0.315 \\
0.315\end{array}$ & $\begin{array}{ll}0.315 \\
\ddots \quad 0.315 \\
0 & 0.315\end{array}$ & $\begin{array}{l}\text { A) } \\
\text { B) } \\
\text { C) }\end{array}$ & $\begin{array}{l}0.315 \\
0.315 \\
0.315\end{array}$ & $\begin{array}{l}0.315 \\
0.315 \\
0.315\end{array}$ \\
\hline
\end{tabular}




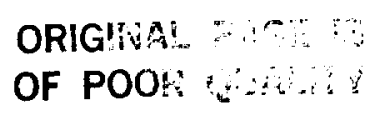

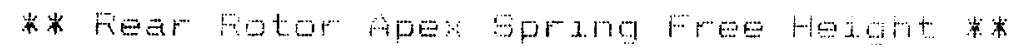

\begin{tabular}{|c|c|c|c|c|c|c|c|c|}
\hline $\begin{array}{r}\text { Sut } \\
\text { Aluint }\end{array}$ & 14 & 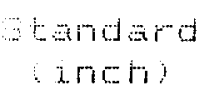 & & $\begin{array}{l}\text { mes } \\
\text { inchi }\end{array}$ & $\begin{array}{l}\text { Fe } \\
\text { (niï) }\end{array}$ & & $\begin{array}{c}\text { pot } \\
1, \cdots n !\end{array}$ & $\begin{array}{l}\text { fost } \\
\text { immi }\end{array}$ \\
\hline$\theta$ & : & $\begin{array}{c}m 1 \pi \\
.1810\end{array}$ & $\begin{array}{l}\mathrm{i} \\
\mathrm{B}) \\
0\end{array}$ & $\begin{array}{r}2160 \\
.2150 \\
.2140\end{array}$ & $\begin{array}{l}3.464 \\
5.4610 \\
5.456\end{array}$ & $\begin{array}{l}a i \\
3 i \\
0\end{array}$ & $\begin{array}{l}.190 \\
.2190 \\
.2150\end{array}$ & $\begin{array}{l}5.57 \% \\
3.5620 \\
\because 4610\end{array}$ \\
\hline $\mathrm{E})$ & $\therefore$ & & $\begin{array}{l}\text { a) } \\
\mathrm{E} \\
\mathrm{C}\end{array}$ & $\begin{array}{r}.2190 \\
.2190 \\
.2150\end{array}$ & $\begin{array}{l}5.597 \\
-5626 \\
5.4610\end{array}$ & $\begin{array}{l}a) \\
i \\
0\end{array}$ & $\begin{array}{r}0.0210 \\
92140 \\
.2120\end{array}$ & $\begin{array}{l}0.52 .4 \\
3.4 .56 \\
5.2048\end{array}$ \\
\hline $\mathrm{c}$ & 1 & & $\begin{array}{l}\text { a) } \\
\mathrm{B} \\
\mathrm{i}\end{array}$ & $\begin{array}{r}.0210 \\
.2140 \\
.2120\end{array}$ & 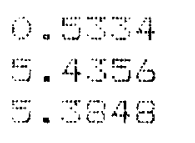 & $\begin{array}{l}\text { a) } \\
\text { a) } \\
6)\end{array}$ & $\begin{array}{l}0210 \\
.2140 \\
2120\end{array}$ & $\begin{array}{l}5.5 .54 \\
5.450 \\
5.5646\end{array}$ \\
\hline i... & $\ldots$ & & $\begin{array}{l}\text { A) } \\
\text { B) } \\
\text { C) }\end{array}$ & $\begin{array}{r}.191 \\
.191 \\
.191\end{array}$ & $\begin{array}{r}0.181 \\
.161 \\
0.191\end{array}$ & $\begin{array}{l}\text { A } \\
\mathrm{B} \\
\mathrm{C}\end{array}$ & $\begin{array}{r}-191 \\
-\quad .191 \\
-191\end{array}$ & $\begin{array}{r}0.101 \\
0.191 \\
.191\end{array}$ \\
\hline$\omega$ & 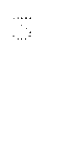 & & $\begin{array}{l}A \\
B \\
0\end{array}$ & $\begin{array}{r}.181 \\
.181 \\
.181\end{array}$ & $\begin{array}{r}0.191 \\
. .191 \\
.191\end{array}$ & $\begin{array}{l}A) \\
B \\
i\end{array}$ & $\begin{array}{l}\ddots .191 \\
\ddots \quad .191 \\
0.191\end{array}$ & $\begin{array}{r}. .61 \\
0.131 \\
.131\end{array}$ \\
\hline c) & 4 & & $\begin{array}{l}A \\
B) \\
B\end{array}$ & $\begin{array}{r}0.181 \\
.181 \\
.131\end{array}$ & $\begin{array}{r}.181 \\
0.181 \\
0.191\end{array}$ & $\begin{array}{l}\text { A) } \\
B) \\
C ;\end{array}$ & $\begin{array}{l}0.181 \\
0.181 \\
0.181\end{array}$ & $\begin{array}{l}0.131 \\
0.131 \\
0.131\end{array}$ \\
\hline$D)$ & $i$ & & $\begin{array}{l}A \\
\theta \\
0\end{array}$ & $\begin{array}{r}.181 \\
0.181 \\
0.181\end{array}$ & $\begin{array}{r}0.191 \\
0.191 \\
.191\end{array}$ & $\begin{array}{l}\text { A) } \\
B) \\
\text { Ci }\end{array}$ & $\begin{array}{l}\gamma \quad 0101 \\
y=131 \\
\because \quad 0.101\end{array}$ & $\begin{array}{r}0.181 \\
0.181 \\
0.181\end{array}$ \\
\hline b) & 2 & & $\begin{array}{l}A) \\
B ; \\
C ;\end{array}$ & $\begin{array}{r}0.181 \\
.181 \\
0.181\end{array}$ & $\begin{array}{r}.191 \\
\quad .181 \\
.191\end{array}$ & $\begin{array}{l}\text { A) } \\
\text { B) } \\
\text { C) }\end{array}$ & $\begin{array}{l}0.191 \\
0.191 \\
0.101\end{array}$ & $\begin{array}{r}0.181 \\
0.181 \\
0.181\end{array}$ \\
\hline D) & 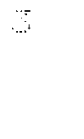 & & $\begin{array}{l}\text { A) } \\
\text { B) } \\
\text { C) }\end{array}$ & $\begin{array}{l}0.181 \\
0.181 \\
0.181\end{array}$ & $\begin{array}{l}0.131 \\
0.181 \\
0.131\end{array}$ & $\begin{array}{l}\text { A) } \\
\text { B) } \\
\text { E) }\end{array}$ & $\begin{array}{r}0.101 \\
0.181 \\
0.101\end{array}$ & $\begin{array}{l}0.191 \\
0.181 \\
0.181\end{array}$ \\
\hline D) & 4 & & $\begin{array}{l}\text { A) } \\
\text { B) } \\
\text { C) }\end{array}$ & $\begin{array}{l}0.181 \\
0.181 \\
0.181\end{array}$ & $\begin{array}{l}0.181 \\
0.181 \\
0.181\end{array}$ & $\begin{array}{l}\text { A) } \\
\text { E) } \\
\text { C) }\end{array}$ & $\begin{array}{ll}0.181 \\
0.181 \\
0.181\end{array}$ & $\begin{array}{l}0.181 \\
0.181 \\
0.181\end{array}$ \\
\hline
\end{tabular}


w wear fotor foes seal wedont w

\begin{tabular}{|c|c|c|c|c|c|}
\hline $\begin{array}{r}\text { Bu } \\
\text { Sum }\end{array}$ & 10 & & $\begin{array}{c}F+e \\
(a)\end{array}$ & $\begin{array}{c}F 0 \leq t \\
17\end{array}$ & $\begin{array}{c}\text { Diterence } \\
9\end{array}$ \\
\hline$\cdots$ & i. & $\begin{array}{l}13 \\
13 \\
3\end{array}$ & $\begin{array}{l}17 \\
13 \\
13 \\
13,12\end{array}$ & $\begin{array}{l}x+19 \\
13-21 \\
3 y-10\end{array}$ & $\begin{array}{l}0.0 \\
0.0 \\
y .0\end{array}$ \\
\hline 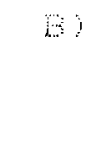 & $\vdots$ & $\begin{array}{l}\text { i } \\
\mathrm{Bi} \\
\mathrm{Ci}\end{array}$ & $\begin{array}{l}1=-10 \\
1-21 \\
1: 19\end{array}$ & $\begin{array}{l}13 \cdot 14 \\
13.16 \\
13.13\end{array}$ & $\begin{array}{l}1.0 \\
0.0 \\
0.6\end{array}$ \\
\hline$\ldots i$ & 1 & 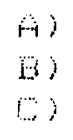 & $\begin{array}{l}1 \Xi \cdot 4 \\
1 \Xi \cdot 16 \\
1 \Xi \cdot 13\end{array}$ & $\begin{array}{l}1-1 \\
10.16 \\
13-1\end{array}$ & $\begin{array}{l}0.00 \\
0.00 \\
.00\end{array}$ \\
\hline $\mathrm{C}$ & $\therefore$ & $\begin{array}{l}4 \\
1 j \\
5 j\end{array}$ & $\begin{array}{l}1-04 \\
4-16 \\
\square-19\end{array}$ & $\begin{array}{l}1.0 \\
1.1 .5 \\
1.11\end{array}$ & 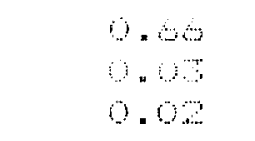 \\
\hline 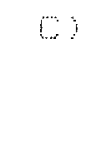 & $\cdots$ & $\begin{array}{l}\mathrm{B} \\
\mathrm{B} i \\
\mathrm{~W}\end{array}$ & $\begin{array}{l}\| A \\
: 1\end{array}$ & $\begin{array}{l}1.26 \\
13.19 \\
13.24\end{array}$ & $\begin{array}{l}\mathrm{NA} \\
" 1 \\
" 1\end{array}$ \\
\hline 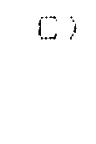 & 4 & $\begin{array}{l}A \\
B i \\
B\end{array}$ & $\begin{array}{l}13.26 \\
1.24 \\
13.19\end{array}$ & $\begin{array}{l}1.24 \\
1-22 \\
13.19\end{array}$ & $\begin{array}{r}0.02 \\
-02 \\
-0.01\end{array}$ \\
\hline D) & 1. & $\begin{array}{l}A) \\
b) \\
b)\end{array}$ & $\begin{array}{l}N A \\
\because 1\end{array}$ & $\begin{array}{l}1.20 \\
1-10 \\
1.13\end{array}$ & $\begin{array}{l}N A \\
11 \\
11\end{array}$ \\
\hline$D$ & $\therefore$ & $\begin{array}{l}A ; \\
\text { a) } \\
C)\end{array}$ & $\begin{array}{l}15.17 \\
15.22 \\
15.11\end{array}$ & $\begin{array}{l}15.12 \\
15.10 \\
15.02\end{array}$ & $\begin{array}{l}0.05 \\
0.13 \\
0.09\end{array}$ \\
\hline$D^{j}$ & $\because$ & $\begin{array}{l}A) \\
B) \\
B)\end{array}$ & $\begin{array}{l}14.99 \\
15.01 \\
15.01\end{array}$ & $\begin{array}{l}14.95 \\
15.01 \\
15.01\end{array}$ & $\begin{array}{l}0.07 \\
0.01 \\
0.00\end{array}$ \\
\hline $\mathrm{Di}$ & 4 & $\begin{array}{l}A) \\
B) \\
C)\end{array}$ & $\begin{array}{l}15.09 \\
15.17 \\
15.22\end{array}$ & $\begin{array}{l}12.81 \\
13.14 \\
13.15\end{array}$ & $\begin{array}{l}2.29 \\
2.04 \\
2.07\end{array}$ \\
\hline
\end{tabular}




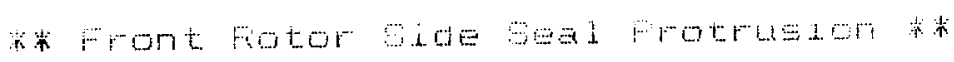

\begin{tabular}{|c|c|c|c|c|c|c|c|c|c|c|}
\hline $\begin{array}{l}\text { But } \\
\text { durino }\end{array}$ & & $\begin{array}{c}\text { Hesgrt } \\
\text { amit } \\
\text { anti }\end{array}$ & & & $\begin{array}{l}\text { Wh } \\
\text { גach }\end{array}$ & $\begin{array}{l}F r e \\
\text { min }\end{array}$ & & & $\begin{array}{l}F o s t \\
(2 \pi) H\end{array}$ & $\begin{array}{c}F=t \\
\text { am }\end{array}$ \\
\hline $1 ;$ & & $\begin{array}{l}\text { min } \\
\text {. कोण }\end{array}$ & $\begin{array}{l}\text { gar } \\
\text { side }\end{array}$ & $\begin{array}{l}A \\
B ; \\
C \\
A \\
B ; \\
C\end{array}$ & $\begin{array}{r}.0500 \\
.0580 \\
.0490 \\
.0590 \\
.0550 \\
.0450\end{array}$ & $\begin{array}{l}1.9700 \\
1.473 \\
1.2446 \\
1.4986 \\
1 . .990 \\
1.1480\end{array}$ & $\begin{array}{l}\text { gear } \\
\text { ende }\end{array}$ & $\begin{array}{l}a \\
B) \\
b) \\
b ; \\
b ;\end{array}$ & $\begin{array}{r}.0450 \\
.0420 \\
0.0490 \\
.0500 \\
.050 \\
.0490\end{array}$ & $\begin{array}{r}.480 \\
.9660 \\
1.2440 \\
1.2700 \\
1.340 \\
. .2440\end{array}$ \\
\hline B) & : & & $\begin{array}{l}\text { gear } \\
\text { ade }\end{array}$ & $\begin{array}{l}A) \\
B ; \\
E \\
\theta \\
B ? \\
D\end{array}$ & $\begin{array}{r}0.0450 \\
.0490 \\
.0490 \\
.0500 \\
.0500 \\
.0490\end{array}$ & $\begin{array}{l}1.1450 \\
1.1430 \\
1.2446 \\
1.2700 \\
1.3462 \\
1.2446\end{array}$ & $\begin{array}{l}\text { aear } \\
91 d 9\end{array}$ & $\begin{array}{l}A) \\
B i \\
6 \\
9 \\
9 \\
b\end{array}$ & $\begin{array}{l}.0500 \\
.0420 \\
.0450 \\
.0450 \\
.0500 \\
.0400\end{array}$ & $\begin{array}{l}1.2700 \\
1.0660 \\
1.1450 \\
1.1450 \\
1.2700 \\
1.1490\end{array}$ \\
\hline$i$ & 1 & & $\begin{array}{l}\text { gear } \\
\text { side }\end{array}$ & $\begin{array}{l}A ; \\
B ? \\
B \\
A ? \\
B ? \\
D ?\end{array}$ & $\begin{array}{r}.0500 \\
.0420 \\
.0450 \\
.0450 \\
.0500 \\
.0450\end{array}$ & $\begin{array}{l}1.2700 \\
1.9008 \\
1.1450 \\
1.1450 \\
1.2700 \\
1.1430\end{array}$ & $\begin{array}{l}9=-\cdots \\
s 20\end{array}$ & $\begin{array}{l}a) \\
b) \\
b \\
\theta \\
b \\
0\end{array}$ & $\begin{array}{l}0.0500 \\
.0420 \\
0.0450 \\
.0450 \\
0.0500 \\
0.0450\end{array}$ & $\begin{array}{l}1.2700 \\
1.0660 \\
1.1450 \\
1.1450 \\
1.2700 \\
1.1480\end{array}$ \\
\hline C) & $=$ & & $\begin{array}{l}\text { gear } \\
\text { gide }\end{array}$ & $\begin{array}{l}\text { A) } \\
\text { B) } \\
\text { C) } \\
\text { A) } \\
\text { B) } \\
\text { C) }\end{array}$ & $\begin{array}{r}0.020 \\
0.020 \\
0.020 \\
0.020 \\
0.020 \\
0.020\end{array}$ & $\begin{array}{r}.020 \\
0.020 \\
0.020 \\
0.020 \\
0.020 \\
.020\end{array}$ & $\begin{array}{l}\text { gear } \\
\text { side }\end{array}$ & $\begin{array}{l}\text { A) } \\
B) \\
\text { C) } \\
\text { A) } \\
\text { B) } \\
\text { C) }\end{array}$ & $\begin{array}{l}0.020 \\
0.020 \\
0.020 \\
0.020 \\
0.020 \\
0.020\end{array}$ & $\begin{array}{r}0.020 \\
0.020 \\
0.020 \\
0.020 \\
0.020 \\
0.020\end{array}$ \\
\hline C) & 5 & & $\begin{array}{l}\text { gear } \\
\text { side }\end{array}$ & $\begin{array}{l}\text { A) } \\
\text { B) } \\
\text { C) } \\
\text { A) } \\
\text { B) } \\
\text { C) }\end{array}$ & $\begin{array}{r}0.020 \\
0.020 \\
0.020 \\
0.020 \\
0.020 \\
0.020\end{array}$ & $\begin{array}{r}0.020 \\
0.020 \\
0.020 \\
0.020 \\
0.020 \\
0.020\end{array}$ & $\begin{array}{l}\text { gear } \\
\text { side }\end{array}$ & $\begin{array}{l}\text { A) } \\
B) \\
\text { C) } \\
\text { A) } \\
\text { B) } \\
\text { C) }\end{array}$ & $\begin{array}{l}0.020 \\
0.020 \\
0.020 \\
0.020 \\
0.020 \\
0.020\end{array}$ & $\begin{array}{r}0.020 \\
0.020 \\
0.020 \\
0.020 \\
0.020 \\
0.020\end{array}$ \\
\hline C) & 4 & & $\begin{array}{l}\text { gear } \\
\text { side }\end{array}$ & $\begin{array}{l}\text { A) } \\
\text { B) } \\
\text { C) } \\
\text { A) } \\
\text { B) } \\
\text { C) }\end{array}$ & $\begin{array}{ll}0.020 \\
0.020 \\
0 & 0.020 \\
2 & 0.020 \\
2 & 0.020 \\
2 & 0.020\end{array}$ & $\begin{array}{l}0.020 \\
0.020 \\
0.020 \\
0.020 \\
00.020 \\
0.020\end{array}$ & $\begin{array}{l}\text { gear } \\
\text { side }\end{array}$ & $\begin{array}{l}\text { A) } \\
\text { B) } \\
\text { C) } \\
\text { A) } \\
\text { B) } \\
\text { C) }\end{array}$ & $\begin{array}{l}0.020 \\
0.020 \\
0.020 \\
0.020 \\
0.020 \\
0.020\end{array}$ & $\begin{array}{l}0.020 \\
0.020 \\
0.020 \\
0.020 \\
00.020 \\
0.020\end{array}$ \\
\hline D) & 1 & & $\begin{array}{l}\text { gear } \\
\text { side }\end{array}$ & $\begin{array}{l}\text { A) } \\
\text { B) } \\
\text { C) } \\
\text { A) } \\
\text { B) } \\
\text { C) }\end{array}$ & $\begin{array}{l}0.020 \\
0.020 \\
80.020 \\
0.020 \\
0.020 \\
0.020\end{array}$ & $\begin{array}{l}0.020 \\
30.020 \\
0.020 \\
0.020 \\
0.020 \\
0.020\end{array}$ & $\begin{array}{l}\text { gear } \\
\text { side }\end{array}$ & $\begin{array}{l}\text { A) } \\
\text { B) } \\
\text { C) } \\
\text { A) } \\
\text { B) } \\
\text { C) }\end{array}$ & $\begin{array}{l}0.020 \\
0.020 \\
0.020 \\
0.020 \\
0.020 \\
0.020\end{array}$ & $\begin{array}{l}0.020 \\
y 0.020 \\
00.020 \\
y 0.020 \\
\Rightarrow 0.020 \\
0.020\end{array}$ \\
\hline
\end{tabular}


I

Or.

* Fromt Rotor side Seal Frotrusjon + *

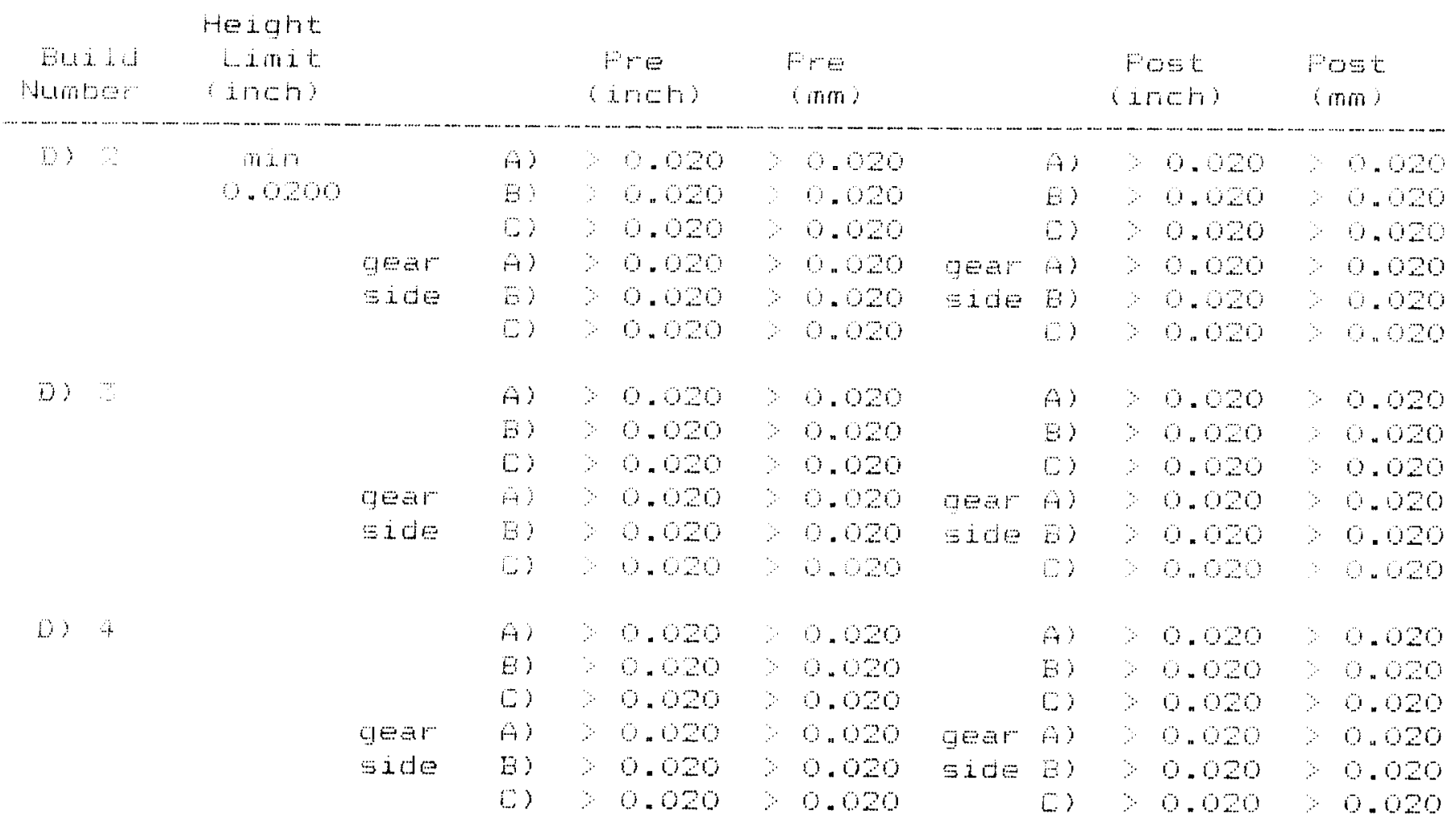


ORIGIR:AL

OF POOR QUAE?

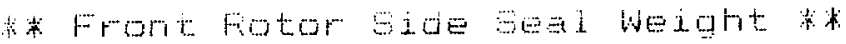

\begin{tabular}{|c|c|c|c|c|c|c|}
\hline Nent & & & & $\begin{array}{c}m= \\
9\end{array}$ & $\begin{array}{c}F_{0}=t \\
9\end{array}$ & $\begin{array}{c}\text { Difference } \\
\text { Pre post } \\
\text { (g) }\end{array}$ \\
\hline$\ldots$ & 1 & $\begin{array}{l}\text { gear } \\
=1 \mathrm{de}\end{array}$ & $\begin{array}{l}A ; \\
B) \\
E ; \\
A ? \\
B) \\
B ?\end{array}$ & $\begin{array}{r}3.91 \\
3.96 \\
3.99 \\
.99 \\
4.90 \\
.99\end{array}$ & $\begin{array}{l}3.77 \\
3.94 \\
3.98 \\
3.98 \\
3.97 \\
3.98\end{array}$ & $\begin{array}{r}0.0 \\
.01 \\
.01 \\
.01 \\
.0 \mathrm{a} \\
.01\end{array}$ \\
\hline$E$ & 1 & $\begin{array}{l} \\
\text { dear } \\
\text { gide }\end{array}$ & $\begin{array}{l}\text { A) } \\
B) \\
0 ; \\
A) \\
B) \\
D\end{array}$ & $\begin{array}{l}.97 \\
\therefore .95 \\
-.99 \\
.90 \\
x .97 \\
\therefore .90\end{array}$ & $\begin{array}{l}3.91 \\
x .97 \\
3.08 \\
4.00 \\
4.00 \\
4.00\end{array}$ & $\begin{array}{r}0.06 \\
-0.02 \\
0.11 \\
-0.02 \\
-0.03 \\
-0.0\end{array}$ \\
\hline$\ldots$ & ! & $\begin{array}{l}\text { gear } \\
\text { =ide }\end{array}$ & $\begin{array}{l}A) \\
B) \\
\text { i) } \\
\text { A) } \\
B> \\
\text { C) }\end{array}$ & $\begin{array}{l}-.71 \\
2.97 \\
3.90 \\
4.00 \\
4.00 \\
4.00\end{array}$ & $\begin{array}{l}3.91 \\
x .97 \\
3.68 \\
4.00 \\
4.00 \\
4.00\end{array}$ & $\begin{array}{l}.00 \\
0.00 \\
.00 \\
0.00 \\
.00 \\
0.00\end{array}$ \\
\hline C) & 2 & $\begin{array}{l}\text { gear } \\
\text { side }\end{array}$ & $\begin{array}{l}\text { A) } \\
\text { B) } \\
\text { C) } \\
\text { A) } \\
\text { B) } \\
\text { C) }\end{array}$ & $\begin{array}{l}.91 \\
3.97 \\
3.68 \\
4.00 \\
4.00 \\
4.00\end{array}$ & $\begin{array}{l}5.91 \\
3.97 \\
3.88 \\
4.00 \\
4.00 \\
4.00\end{array}$ & $\begin{array}{l}.00 \\
0.00 \\
0.00 \\
0.00 \\
0.00 \\
0.00\end{array}$ \\
\hline$\omega$ & ఈ & $\begin{array}{l}\text { gear } \\
\text { side }\end{array}$ & $\begin{array}{l}\text { A) } \\
\text { B) } \\
\text { C) } \\
\text { A) } \\
\text { E) } \\
\text { C) }\end{array}$ & $\begin{array}{l}.91 \\
3.97 \\
3.80 \\
4.00 \\
4.00 \\
4.00\end{array}$ & $\begin{array}{l}3.94 \\
3.97 \\
-.99 \\
3.99 \\
3.99 \\
4.00\end{array}$ & $\begin{array}{r}-0.05 \\
0.00 \\
-0.10 \\
0.01 \\
0.01 \\
0.00\end{array}$ \\
\hline C) & 4 & $\begin{array}{l}\text { gear } \\
\text { side }\end{array}$ & $\begin{array}{l}\text { A) } \\
\text { E) } \\
\text { C) } \\
\text { A) } \\
\text { B) } \\
\text { C) }\end{array}$ & $\begin{array}{l}3.94 \\
3.97 \\
3.93 \\
3.99 \\
-.99 \\
4.00\end{array}$ & $\begin{array}{l}4.01 \\
4.02 \\
5.98 \\
5.97 \\
3.97 \\
4.01\end{array}$ & $\begin{array}{r}-0.06 \\
-0.05 \\
0.00 \\
0.01 \\
0.01 \\
-0.01\end{array}$ \\
\hline D) & 1 & $\begin{array}{l}\text { gear } \\
\text { side }\end{array}$ & $\begin{array}{l}\text { A) } \\
\text { E) } \\
\text { C) } \\
\text { A) } \\
\text { B) } \\
\text { C) }\end{array}$ & $\begin{array}{l}\text { NA } \\
" 1 \\
" 1 \\
" 1 \\
" 1\end{array}$ & $\begin{array}{l}3.97 \\
3.95 \\
3.96 \\
3.97 \\
5.97 \\
4.01\end{array}$ & $\begin{array}{l}\text { NA } \\
" 1 \\
" 1 \\
" 1 \\
" 1\end{array}$ \\
\hline
\end{tabular}


ORIGIA:
OF POOR Gunin:

W Front fotor side geal Hedatit

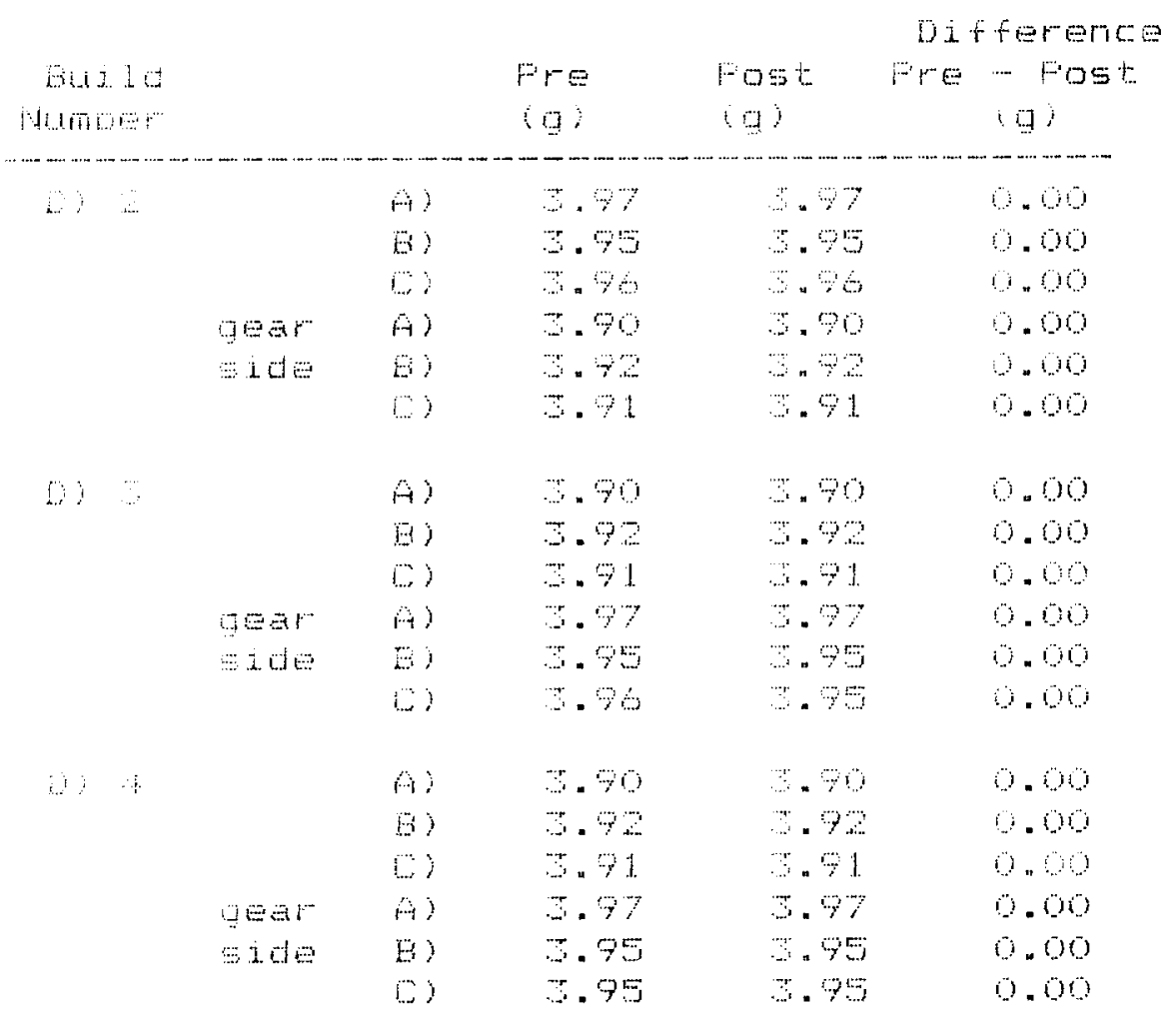




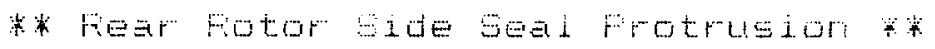

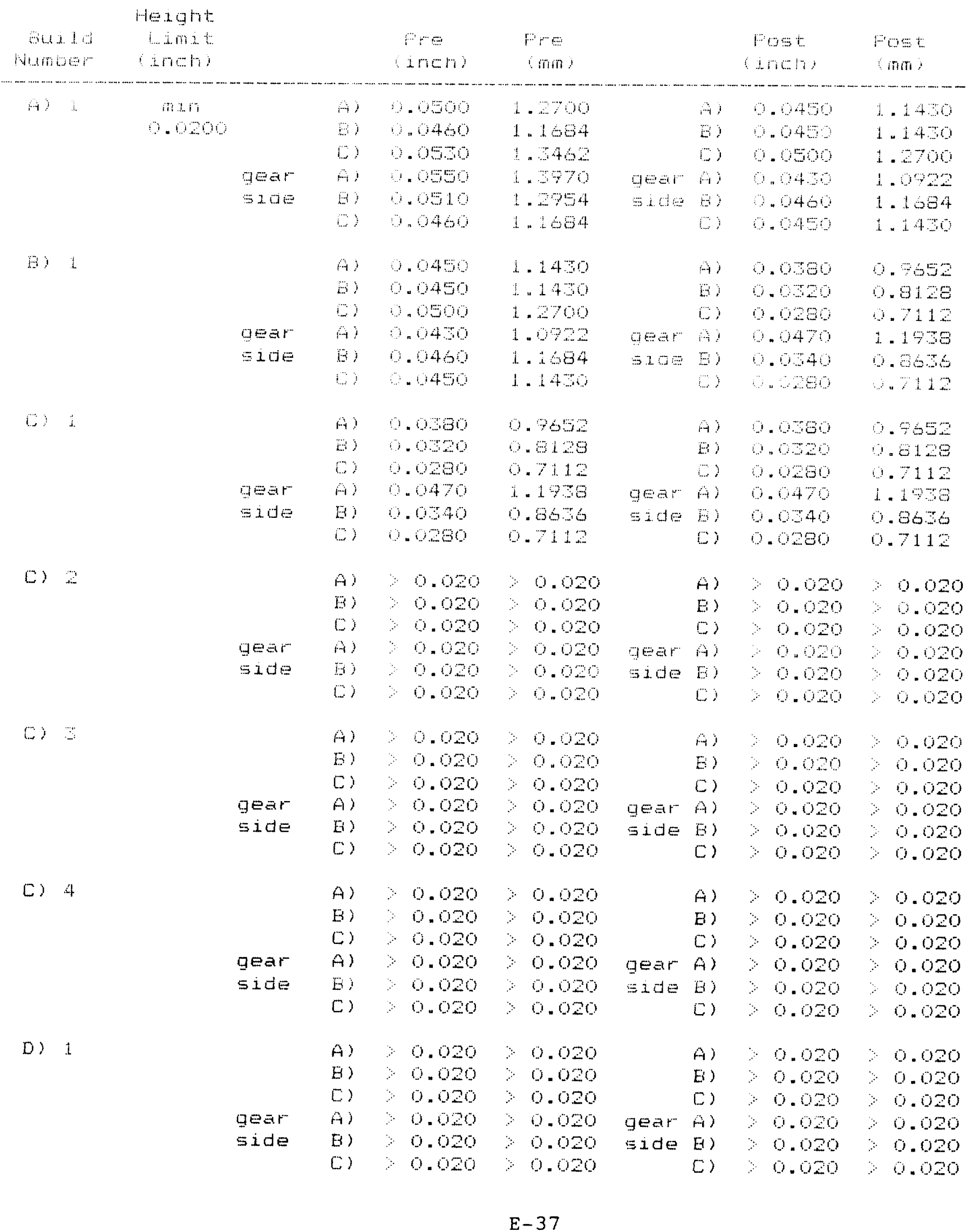


ORICISAL PAOE IS

OF POOR QUALITY

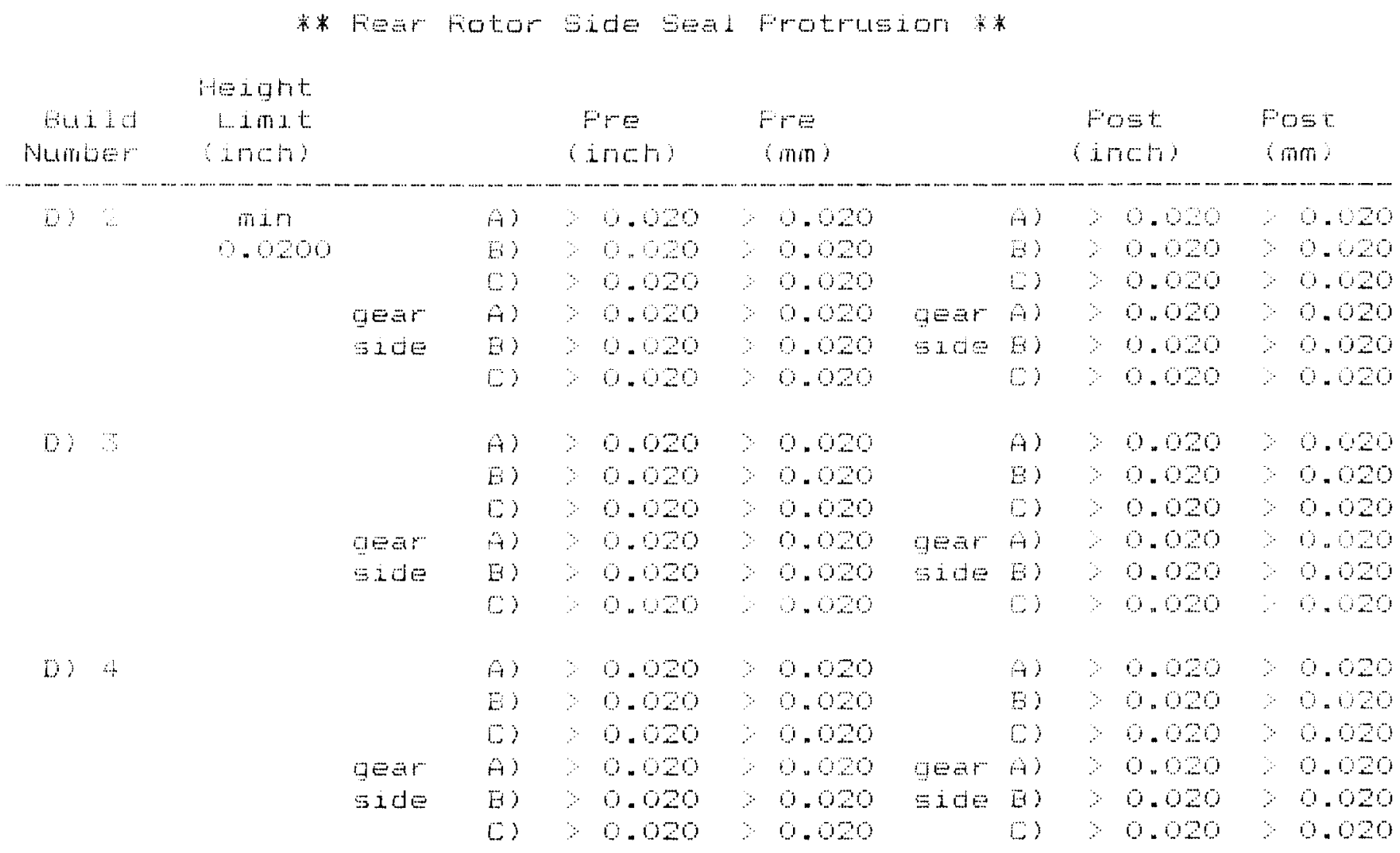


* Fear Fotor Side Seal Weight * *

\section{ORIGINAL PACE IS \\ OF POOR QUAL.ITY}

\begin{tabular}{|c|c|c|c|c|c|c|}
\hline \multicolumn{2}{|c|}{$\begin{array}{r}\text { Eutida } \\
\text { Number }\end{array}$} & & & $\begin{array}{c}F+e \\
(g)\end{array}$ & $\begin{array}{c}\text { Fost } \\
(q)\end{array}$ & $\begin{array}{c}\text { Difference } \\
\text { Fre - Fost } \\
\text { (q) }\end{array}$ \\
\hline$A)$ & 1 & $\begin{array}{l}\text { gear } \\
\text { side }\end{array}$ & $\begin{array}{l}\text { A) } \\
\text { B) } \\
\text { C) } \\
\text { A) } \\
\text { B) } \\
\text { C) }\end{array}$ & $\begin{array}{l}.90 \\
3.99 \\
.99 \\
4.03 \\
4.02 \\
4.02\end{array}$ & $\begin{array}{l}.99 \\
-.99 \\
.98 \\
4.02 \\
4.02 \\
4.01\end{array}$ & $\begin{array}{r}0.01 \\
0.00 \\
0.01 \\
0.01 \\
0.00 \\
0.01\end{array}$ \\
\hline B) & 1 & $\begin{array}{l}\text { gear } \\
\text { side }\end{array}$ & $\begin{array}{l}\text { A) } \\
\text { E) } \\
\text { C) } \\
\text { A) } \\
\text { B) } \\
\text { C) }\end{array}$ & $\begin{array}{l}3.99 \\
3.99 \\
3.99 \\
4.02 \\
4.02 \\
4.01\end{array}$ & $\begin{array}{l}3.91 \\
5.94 \\
3.94 \\
4.00 \\
.997 \\
4.00\end{array}$ & $\begin{array}{l}0.08 \\
0.05 \\
0.04 \\
0.02 \\
0.05 \\
0.01\end{array}$ \\
\hline 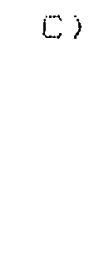 & 1 & $\begin{array}{l}\text { gear } \\
\text { side }\end{array}$ & $\begin{array}{l}\text { A) } \\
\text { B) } \\
\text { C) } \\
\text { A) } \\
\text { E) } \\
\text { C) }\end{array}$ & $\begin{array}{r}.91 \\
-.94 \\
-.94 \\
4.00 \\
3.97 \\
4.00\end{array}$ & $\begin{array}{l}5.91 \\
3.94 \\
-.94 \\
4.00 \\
5.97 \\
4.00\end{array}$ & $\begin{array}{l}0.00 \\
0.00 \\
0.00 \\
0.00 \\
0.00 \\
0.00\end{array}$ \\
\hline C) & 2 & $\begin{array}{l}\text { gear } \\
\text { side }\end{array}$ & $\begin{array}{l}\text { A) } \\
\text { B) } \\
\text { C) } \\
\text { A) } \\
\text { E) } \\
\text { C) }\end{array}$ & $\begin{array}{l}3.91 \\
3.94 \\
3.94 \\
4.00 \\
3.97 \\
4.00\end{array}$ & $\begin{array}{l}3.91 \\
3.94 \\
3.94 \\
4.00 \\
3.97 \\
4.00\end{array}$ & $\begin{array}{l}0.00 \\
0.00 \\
0.00 \\
0.00 \\
0.00 \\
0.00\end{array}$ \\
\hline C) & $\Xi$ & $\begin{array}{l}\text { gear } \\
\text { side }\end{array}$ & $\begin{array}{l}\text { A) } \\
\text { B) } \\
\text { C) } \\
\text { A) } \\
\text { B) } \\
\text { C) }\end{array}$ & $\begin{array}{l}3.98 \\
3.99 \\
3.99 \\
4.03 \\
4.02 \\
4.02\end{array}$ & $\begin{array}{l}3.98 \\
3.98 \\
3.98 \\
4.03 \\
3.98 \\
4.01\end{array}$ & $\begin{array}{l}0.00 \\
0.01 \\
0.01 \\
0.00 \\
0.04 \\
0.01\end{array}$ \\
\hline C) & 4 & $\begin{array}{l}\text { gear } \\
\text { side }\end{array}$ & $\begin{array}{l}\text { A) } \\
\text { B) } \\
\text { C) } \\
\text { A) } \\
\text { B) } \\
\text { C) }\end{array}$ & $\begin{array}{l}3.98 \\
3.98 \\
3.98 \\
4.03 \\
3.98 \\
4.01\end{array}$ & $\begin{array}{l}3.98 \\
3.97 \\
3.99 \\
4.02 \\
3.98 \\
3.99\end{array}$ & $\begin{array}{r}0.00 \\
0.01 \\
-0.01 \\
0.01 \\
0.00 \\
0.02\end{array}$ \\
\hline . & 1 & $\begin{array}{l}\text { gear } \\
\text { side }\end{array}$ & $\begin{array}{l}\text { A) } \\
\text { B) } \\
\text { C) } \\
\text { A) } \\
\text { B) } \\
\text { C) }\end{array}$ & $\begin{array}{l}\text { NA } \\
" 1 \\
" 1 \\
" 1 \\
" 1 \\
" 1\end{array}$ & $\begin{array}{l}3.97 \\
3.97 \\
4.01 \\
4.01 \\
4.02 \\
3.97\end{array}$ & $\begin{array}{l}\text { NA } \\
" 1 \\
" 1 \\
" 1 \\
" 1 \\
" 1\end{array}$ \\
\hline & & & & & & $E-39$ \\
\hline
\end{tabular}




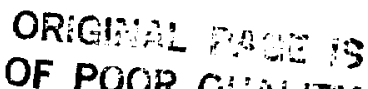

OF POOR GUALITY

* Fear fotor Bide Seal Weight **

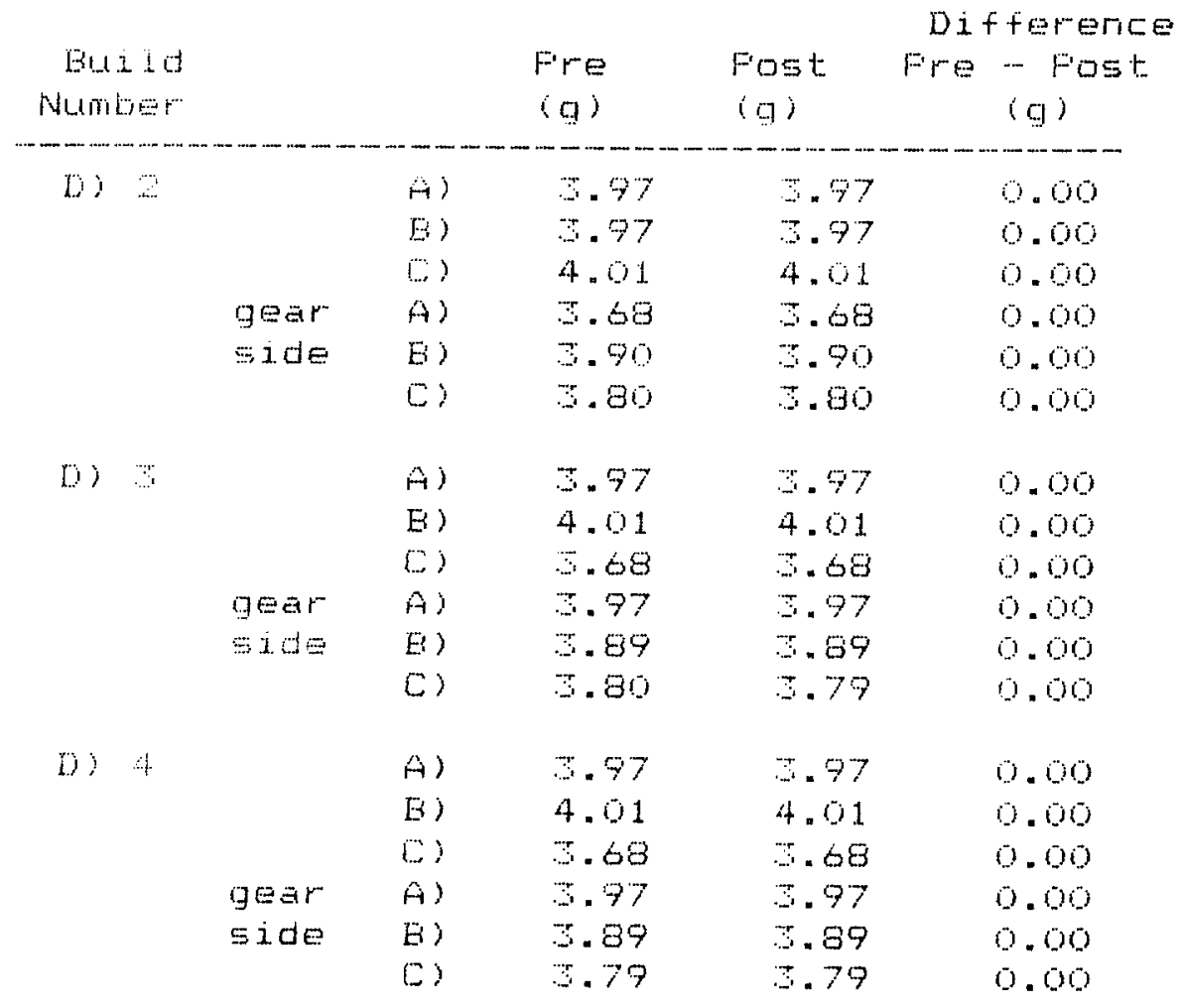


ORIGW

OF POCE

* Front Fotor corner seal Frotruama d

\begin{tabular}{|c|c|c|c|c|c|c|c|c|c|c|}
\hline $\begin{array}{r}\text { buta } \\
\text { Nuirit: }\end{array}$ & $\begin{array}{l}10 \\
6+\end{array}$ & $\begin{array}{l}\text { etodaro } \\
(1, n+m)\end{array}$ & & & $\begin{array}{l}\text { pres } \\
\text { (1moth) }\end{array}$ & $\begin{array}{l}\text { Pre } \\
\text { man })\end{array}$ & & & $\begin{array}{l}\text { most } \\
\text { inch; }\end{array}$ & $\begin{array}{l}\text { Fost: } \\
\text { min: }\end{array}$ \\
\hline (i) & i. & min & $\begin{array}{l}\text { gear } \\
\text { side }\end{array}$ & $\begin{array}{l}A ? \\
B ! \\
C \\
\text { A } \\
B ? \\
C ?\end{array}$ & $\begin{array}{r}0.070 \\
.0540 \\
.0340 \\
.0350 \\
.0260 \\
.0570\end{array}$ & $\begin{array}{l}.9098 \\
0.9050 \\
.5656 \\
.0990 \\
.6604 \\
.909\end{array}$ & $\begin{array}{l}\text { gear } \\
\text { side }\end{array}$ & 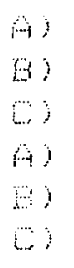 & $\begin{array}{l}.0940 \\
.0290 \\
.050 \\
.0400 \\
.0220 \\
0.0000\end{array}$ & $\begin{array}{l}.0630 \\
.7306 \\
.9892 \\
1.0160 \\
.6120 \\
.7620\end{array}$ \\
\hline E) & $\mathrm{i}$ & & $\begin{array}{l}g e z r \\
g 1 d e\end{array}$ & 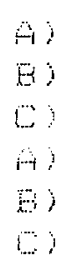 & $\begin{array}{r}0.0450 \\
.0490 \\
.0440 \\
.0400 \\
.050 \\
.0500\end{array}$ & $\begin{array}{l}1.1400 \\
1.2446 \\
1.1176 \\
1.0160 \\
.6120 \\
. .620\end{array}$ & $\begin{array}{l}\text { ges } \\
5 x 0 \%\end{array}$ & $\begin{array}{l}\text { A) } \\
B ? \\
\text { C) } \\
\text { A? } \\
\text { ? } \\
\text { ? }\end{array}$ & $\begin{array}{l}.000 \\
0.0270 \\
.0500 \\
.050 \\
.0450 \\
.0550\end{array}$ & $\begin{array}{r}0.760 \\
0.6950 \\
0.720 \\
0.9396 \\
1.1450 \\
0.6990\end{array}$ \\
\hline$\omega$ & 1 & & $\begin{array}{l}\text { gear } \\
\text { gide }\end{array}$ & $\begin{array}{l}\text { A) } \\
\text { B) } \\
\text { C) } \\
\text { A) } \\
\text { B) } \\
\text { C) }\end{array}$ & $\begin{array}{r}.0300 \\
.0270 \\
.0500 \\
.0370 \\
.0450 \\
.0550\end{array}$ & $\begin{array}{l}.7620 \\
.6850 \\
.7620 \\
0.9398 \\
1.1430 \\
. .9890\end{array}$ & $\begin{array}{l}\text { gear } \\
\text { eide }\end{array}$ & $\begin{array}{l}\text { A) } \\
\text { Bi } \\
\text { Ci } \\
\text { ai } \\
\text { Bi } \\
\text { Ci }\end{array}$ & $\begin{array}{l}0.0500 \\
0.0270 \\
0.0500 \\
0.0970 \\
.0450 \\
.0550\end{array}$ & $\begin{array}{l}0.7620 \\
0.6853 \\
0.7620 \\
0.9598 \\
1.1450 \\
0.6870\end{array}$ \\
\hline C) & 2 & & $\begin{array}{l}\text { gear } \\
\text { gide }\end{array}$ & $\begin{array}{l}\text { A) } \\
\text { B) } \\
\text {; } \\
\text { A) } \\
\text { B) } \\
\text { C) }\end{array}$ & $\begin{array}{l}0.020 \\
\Rightarrow \quad 0.020 \\
0.020 \\
0.020 \\
0.020 \\
0.020\end{array}$ & $\begin{array}{l}0.020 \\
0.020 \\
0.020 \\
0.020 \\
0.020 \\
0.020\end{array}$ & $\begin{array}{l}\text { gear } \\
\text { side }\end{array}$ & $\begin{array}{l}\text { A) } \\
B ? \\
\text { C) } \\
\text { A) } \\
\text { B) } \\
\text { C) }\end{array}$ & $\begin{array}{l}0.020 \\
0.020 \\
0.020 \\
0.020 \\
0.020 \\
0.020\end{array}$ & $\begin{array}{r}0.020 \\
0.020 \\
0.020 \\
0.020 \\
0.020 \\
0.020\end{array}$ \\
\hline $\mathrm{C}$ & $\because$ & & $\begin{array}{l}\text { gear } \\
\text { side }\end{array}$ & $\begin{array}{l}\text { A) } \\
\text { B) } \\
\text { Ci } \\
\text { A) } \\
\text { B) } \\
\text { C) }\end{array}$ & $\begin{array}{r}0.020 \\
0.020 \\
0.020 \\
0.020 \\
0.020 \\
0.020\end{array}$ & $\begin{array}{l}0.020 \\
0.020 \\
0.020 \\
0.020 \\
0.020 \\
0.020\end{array}$ & $\begin{array}{l}\text { gear } \\
\text { side }\end{array}$ & $\begin{array}{l}\text { A) } \\
\text { B) } \\
\text { C) } \\
\text { A) } \\
\text { B) } \\
\text { C) }\end{array}$ & $\begin{array}{l}0.020 \\
0.020 \\
0.020 \\
0.020 \\
0.020 \\
0.020\end{array}$ & $\begin{array}{l}0.020 \\
20.020 \\
0.020 \\
0.020 \\
0.020 \\
0.0 .020\end{array}$ \\
\hline C) & 4 & & $\begin{array}{l}\text { gear } \\
\text { side }\end{array}$ & $\begin{array}{l}\text { A) } \\
\text { B) } \\
\text { C) } \\
\text { A) } \\
\text { E) } \\
\text { C) }\end{array}$ & 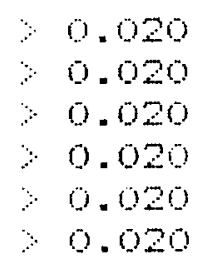 & 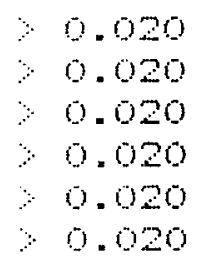 & $\begin{array}{l}\text { gear } \\
\text { side }\end{array}$ & $\begin{array}{l}\text { A) } \\
\text { B) } \\
\text { C) } \\
\text { A) } \\
\text { B) } \\
\text { C) }\end{array}$ & $\begin{array}{l}0.020 \\
0.020 \\
0.020 \\
0.020 \\
0.020 \\
0.020\end{array}$ & $\begin{array}{l}0.020 \\
00.020 \\
0.020 \\
0.020 \\
0.020 \\
0.020\end{array}$ \\
\hline D) & 1 & & $\begin{array}{l}\text { gear } \\
\text { side }\end{array}$ & $\begin{array}{l}\text { A) } \\
\text { B) } \\
\text { C) } \\
\text { A) } \\
\text { B) } \\
\text { C) }\end{array}$ & $\begin{array}{l}\gamma \quad 0.020 \\
\gamma \quad 0.020 \\
0.020 \\
\gamma \quad 0.020 \\
\gamma \quad 0.020 \\
\gamma \quad 0.020\end{array}$ & $\begin{array}{l}0.020 \\
0.020 \\
0.020 \\
0.020 \\
0.020 \\
0.020\end{array}$ & $\begin{array}{l}\text { gear } \\
\text { side }\end{array}$ & $\begin{array}{l}\text { A) } \\
\text { B) } \\
\text { C) } \\
\text { A) } \\
\text { B) } \\
\text { C) }\end{array}$ & $\begin{array}{l}0.0060 \\
0.0080 \\
0.0070 \\
0.020 \\
0.020 \\
0.020\end{array}$ & $\begin{array}{l}0.1524 \\
0.2032 \\
0.1770 \\
0.020 \\
0.020 \\
0.020\end{array}$ \\
\hline
\end{tabular}


OR⿴囗十⺝

OF POCR QuAny

w wont Fotor Gorner beal frotmision

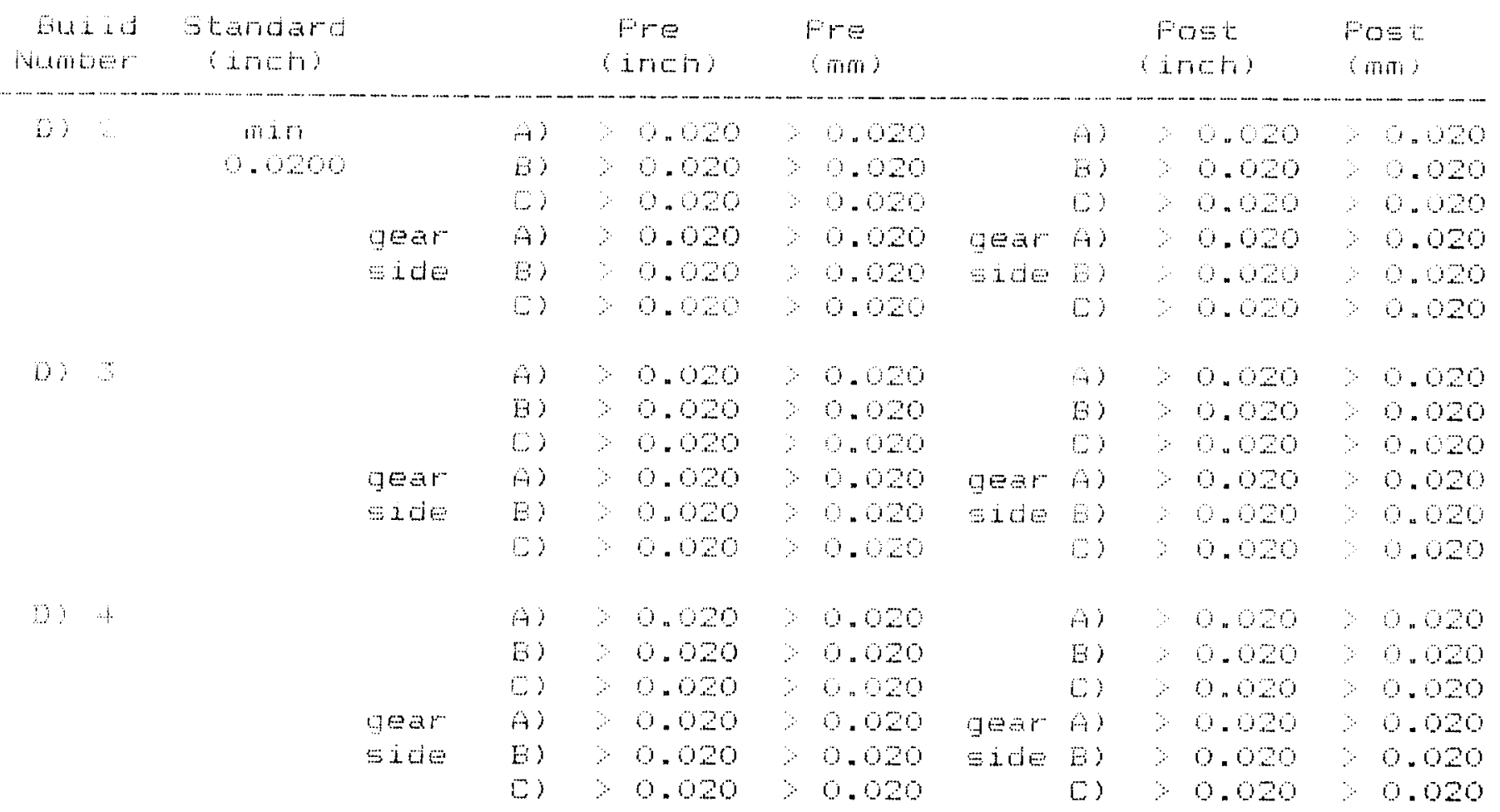


** Front Fotor Corner Seal Weight **

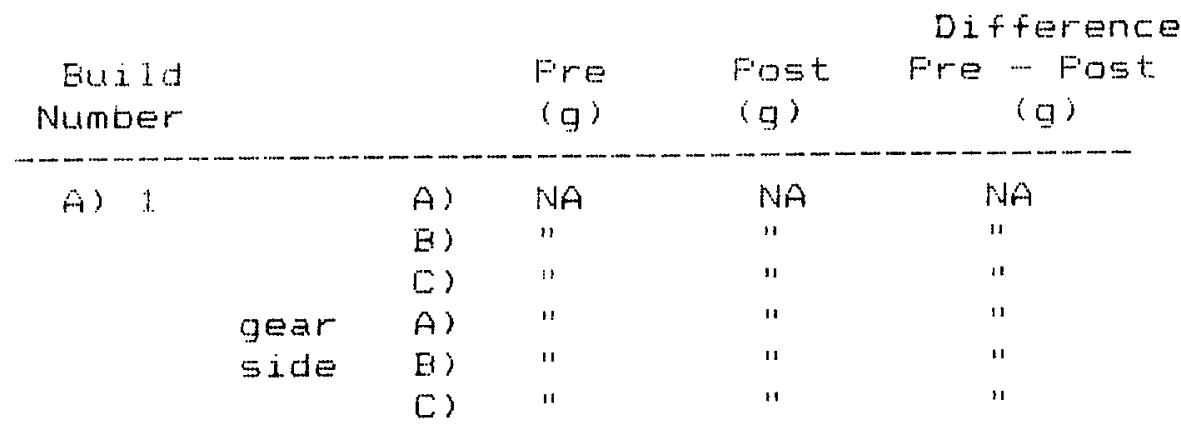

E) 1

\begin{tabular}{|c|c|c|c|c|}
\hline & A) & 2.68 & 2.67 & 0.01 \\
\hline & B) & 2.68 & 2.64 & 0.04 \\
\hline & C) & 2.67 & 2.67 & 0.00 \\
\hline ar & $A$ & 2.68 & 2.67 & 0.01 \\
\hline ide & B) & 2.67 & 2.67 & 0.00 \\
\hline & C) & 2.70 & 2.69 & 0.01 \\
\hline
\end{tabular}

C) 1

$\begin{array}{rrrrr} & \text { A) } & 2.67 & 2.67 & 0.00 \\ & \text { B) } & 2.64 & 2.64 & 0.00 \\ \text { gear } & \text { C) } & 2.67 & 2.67 & 0.00 \\ \text { side } & 2.67 & 2.67 & 0.00 \\ & \text { B) } & 2.67 & 2.67 & 0.00 \\ & \text { C) } & 2.69 & 2.69 & 0.00\end{array}$

C) 2

\begin{tabular}{|c|c|c|c|c|}
\hline & A) & 2.67 & 2.67 & 0.00 \\
\hline & B) & 2.64 & 2.64 & 0.00 \\
\hline & C) & 2.67 & 2.67 & 0.00 \\
\hline & A) & 2.67 & 2.67 & 0.00 \\
\hline ide & E) & 2.67 & 2.67 & 0.00 \\
\hline & C) & 2.69 & 2.69 & 0.00 \\
\hline
\end{tabular}

c) 3

$\begin{array}{rrrrr} & \text { A) } & 2.67 & 2.67 & 0.00 \\ & \text { B) } & 2.64 & 2.68 & -0.04 \\ \text { gear } & \text { C) } & 2.67 & 2.68 & -0.01 \\ \text { Side } & 2.67 & 2.69 & -0.02 \\ & \text { B) } & 2.67 & 2.68 & -0.01 \\ & \text { C) } & 2.69 & 2.67 & 0.02\end{array}$

C) 4

$\begin{array}{lllll} & \text { A) } & 2.67 & 2.64 & 0.03 \\ \text { B) } & 2.68 & 2.66 & 0.02 \\ \text { gear } & \text { A) } & 2.68 & 2.68 & 0.00 \\ \text { side } & 2.69 & 2.67 & 0.02 \\ & \text { B) } & 2.68 & 2.67 & 0.01 \\ \text { C) } & 2.67 & 2.67 & 0.00\end{array}$

D) 1

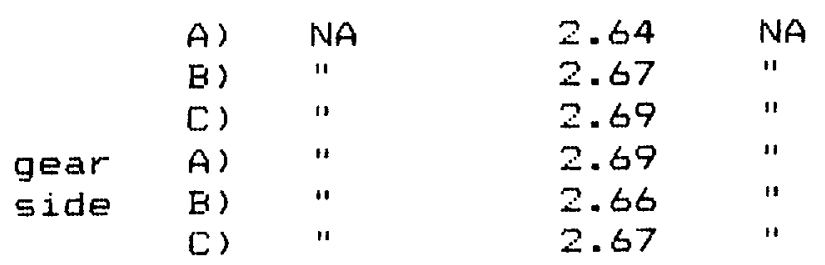


* Front Fotor Corner Seal Weight **

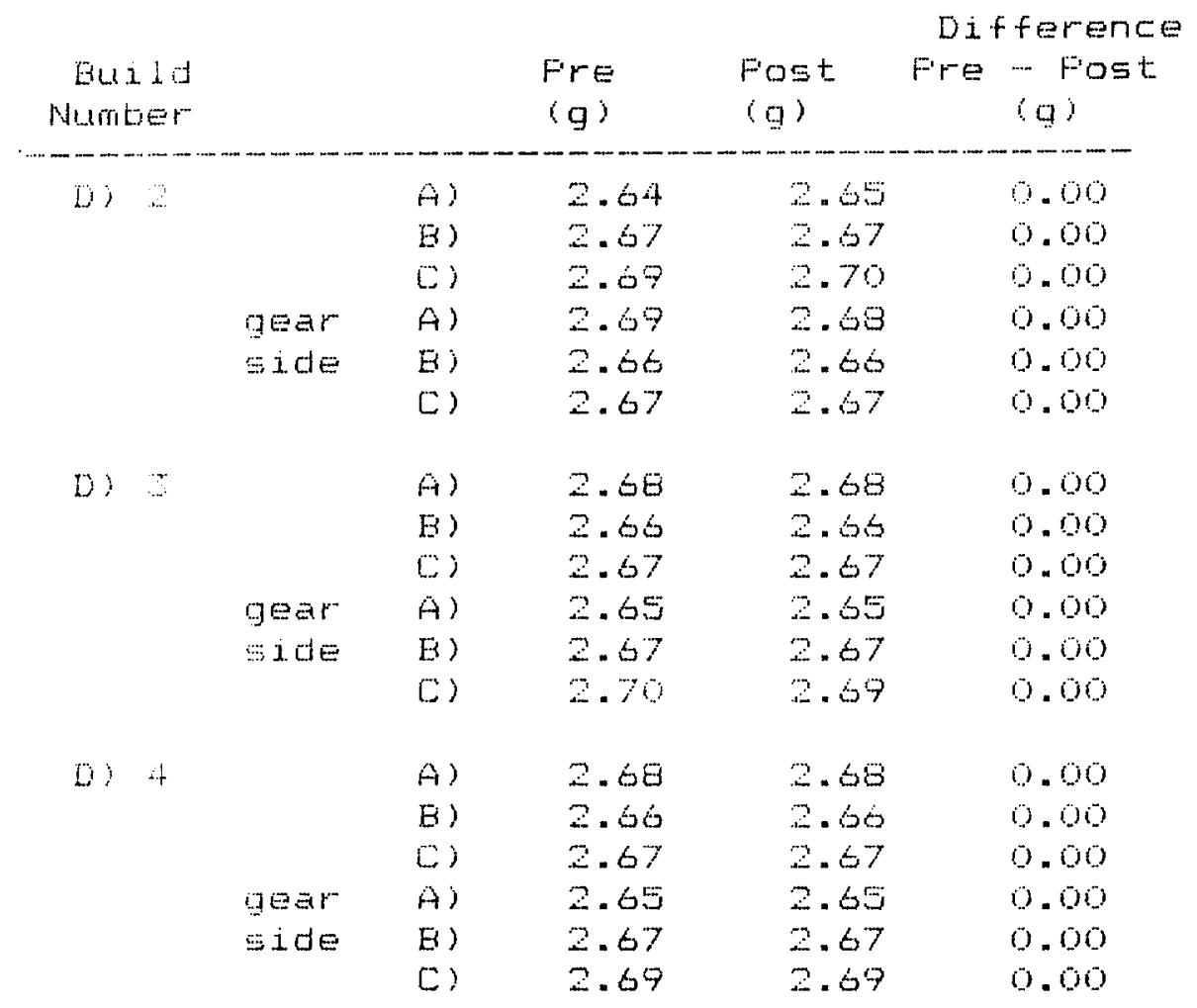




\begin{tabular}{|c|c|c|c|c|c|c|c|c|c|c|}
\hline $\begin{array}{r}\text { Eut } \\
\text { Duinit }\end{array}$ & & $\begin{array}{c}\text { tendard } \\
\text { (now) }\end{array}$ & & & $\begin{array}{l}\text { Fre } \\
\text { (גmoti) }\end{array}$ & $\begin{array}{l}\text { Fre } \\
\text { (mm) }\end{array}$ & & & $\begin{array}{l}\text { Fost } \\
\text { inth) }\end{array}$ & $\begin{array}{l}\text { Post } \\
\text { minti }\end{array}$ \\
\hline+1 & : & $\begin{array}{l}1117 \\
.0200\end{array}$ & $\begin{array}{l}\text { gear } \\
\text { side }\end{array}$ & $\begin{array}{l}A ; \\
B) \\
b \\
A \\
B) \\
B\end{array}$ & $\begin{array}{r}0400 \\
.0570 \\
.0400 \\
.0500 \\
.0400 \\
.0500\end{array}$ & $\begin{array}{r}1.0160 \\
.906 \\
1.0160 \\
.8890 \\
1.0160 \\
.7620\end{array}$ & $\begin{array}{l}\text { gear } \\
\text { side }\end{array}$ & 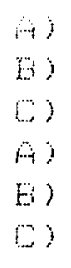 & $\begin{array}{l}.0400 \\
.0020 \\
.0410 \\
.0460 \\
.0080 \\
.0450\end{array}$ & $\begin{array}{l}1.0160 \\
0.6120 \\
1.0414 \\
1.1634 \\
0.9652 \\
1.1430\end{array}$ \\
\hline (B) & i & & $\begin{array}{l}\text { gear } \\
\text { gide: }\end{array}$ & $\begin{array}{l}A) \\
B) \\
\text { : } \\
A) \\
\text { a) } \\
\text { ) }\end{array}$ & $\begin{array}{r}.0570 \\
.0520 \\
.0550 \\
.0450 \\
.0350 \\
.0450\end{array}$ & $\begin{array}{l}1.4478 \\
1.2208 \\
1.3970 \\
1.1684 \\
1.9652 \\
1.1470\end{array}$ & $\begin{array}{l}\text { gear } \\
\text { side }\end{array}$ & $\begin{array}{l}\text { A) } \\
\text { B) } \\
\text { C) } \\
\text { A) } \\
\text { क) } \\
\text { C) }\end{array}$ & $\begin{array}{l}0.0500 \\
0.0510 \\
.0520 \\
.0550 \\
.0510 \\
.0500\end{array}$ & $\begin{array}{l}1.2700 \\
1.2954 \\
1.3208 \\
1.3770 \\
1.2954 \\
1.2700\end{array}$ \\
\hline $\mathrm{C}$ & 1 & & $\begin{array}{l}\text { gear } \\
\text { side }\end{array}$ & $\begin{array}{l}\text { A) } \\
\text { E) } \\
\text { E) } \\
\text { A) } \\
\text { B) } \\
\text { C) }\end{array}$ & $\begin{array}{l}0.0500 \\
0.0510 \\
.0520 \\
0.0550 \\
0.0510 \\
0.0500\end{array}$ & $\begin{array}{l}1.2700 \\
1.2954 \\
1.2208 \\
1.3970 \\
1.2954 \\
1.2700\end{array}$ & $\begin{array}{l}\text { gear } \\
\text { side }\end{array}$ & $\begin{array}{l}A ; \\
\text { B) } \\
\text { C) } \\
\text { A) } \\
\text { B) } \\
\text { C) }\end{array}$ & $\begin{array}{l}0.0500 \\
0.0510 \\
0.0520 \\
0.0550 \\
0.0510 \\
0.0500\end{array}$ & $\begin{array}{l}1.2700 \\
1.2754 \\
1.3208 \\
1.3770 \\
1.2754 \\
1.2700\end{array}$ \\
\hline C) & 2 & & $\begin{array}{l}\text { gear } \\
\text { side }\end{array}$ & $\begin{array}{l}\text { A) } \\
\text { E) } \\
\text { C) } \\
\text { A) } \\
\text { B) } \\
\text { C) }\end{array}$ & $\begin{array}{l}0.020 \\
30.020 \\
00.020 \\
00.020 \\
00.020 \\
0.020\end{array}$ & $\begin{array}{l}0.020 \\
0.020 \\
0.020 \\
0.020 \\
0.020 \\
0.020\end{array}$ & $\begin{array}{l}\text { gear } \\
\text { ide }\end{array}$ & $\begin{array}{l}\text { A) } \\
\text { B) } \\
\text { () } \\
\text { A) } \\
\text { B) } \\
\text { C) }\end{array}$ & $\begin{array}{l}0.020 \\
0.020 \\
0.020 \\
0.020 \\
0.020 \\
0.020\end{array}$ & $\begin{array}{ll}\gamma & 0.020 \\
0 & 0.020 \\
8 & 0.020 \\
0 & 0.020 \\
8 & 0.020 \\
0 & 0.020\end{array}$ \\
\hline C) & $y$ & & $\begin{array}{l}\text { gear } \\
\text { side }\end{array}$ & $\begin{array}{l}\text { A) } \\
\text { E) } \\
\text { C) } \\
\text { A) } \\
\text { B) } \\
\text { C) }\end{array}$ & $\begin{array}{l}0.020 \\
0.020 \\
0.020 \\
0.020 \\
0.020 \\
0.020\end{array}$ & $\begin{array}{l}0.020 \\
0.020 \\
0.020 \\
0.020 \\
00.020 \\
00.020\end{array}$ & $\begin{array}{l}\text { gear } \\
\text { side }\end{array}$ & $\begin{array}{l}\text { A) } \\
\text { E) } \\
\text { C) } \\
\text { A) } \\
\text { B) } \\
\text { C) }\end{array}$ & $\begin{array}{l}0.020 \\
0.020 \\
0.020 \\
0.020 \\
0.020 \\
0.020\end{array}$ & $\begin{array}{ll}9 & 0.020 \\
0 & 0.020 \\
0 & 0.020 \\
0 & 0.020 \\
0 & 0.020 \\
0 & 0.020\end{array}$ \\
\hline C) & 4 & & $\begin{array}{l}\text { gear } \\
\text { side }\end{array}$ & $\begin{array}{l}\text { A) } \\
\text { B) } \\
\text { C) } \\
\text { A) } \\
\text { B) } \\
\text { C) }\end{array}$ & $\begin{array}{ll}0.020 \\
0.020 \\
0.020 \\
0.020 \\
0.020 \\
0.020\end{array}$ & $\begin{array}{l}0.020 \\
0.020 \\
00.020 \\
0.020 \\
0.020 \\
0.020\end{array}$ & $\begin{array}{l}\text { gear } \\
\text { side }\end{array}$ & $\begin{array}{l}\text { A) } \\
\text { B) } \\
\text { C) } \\
\text { A) } \\
\text { B) } \\
\text { C) }\end{array}$ & $\begin{array}{ll}0.020 \\
0 & 0.020 \\
0.020 \\
0 & 0.020 \\
0 & 0.020 \\
0 & 0.020\end{array}$ & $\begin{array}{ll}\gamma & 0.020 \\
y & 0.020 \\
0 & 0.020 \\
0 & 0.020 \\
0 & 0.020 \\
0.020\end{array}$ \\
\hline D) & 1 & & $\begin{array}{l}\text { gear } \\
\text { side }\end{array}$ & $\begin{array}{l}\text { A) } \\
\text { B) } \\
\text { C) } \\
\text { A) } \\
\text { E) } \\
\text { C) }\end{array}$ & $\begin{array}{ll}0 & 0.020 \\
\gamma & 0.020 \\
0 & 0.020 \\
y & 0.020 \\
0 & 0.020 \\
0.020\end{array}$ & $\begin{array}{ll}0.020 \\
20.020 \\
0 & 0.020 \\
0 & 0.020 \\
0 & 0.020 \\
0 & 0.020\end{array}$ & $\begin{array}{l}\text { gear } \\
\text { side }\end{array}$ & $\begin{array}{l}\text { A) } \\
\text { B) } \\
\text { C) } \\
\text { A) } \\
\text { B) } \\
\text { C) }\end{array}$ & $\begin{array}{ll}2 & 0.020 \\
y & 0.020 \\
y & 0.020 \\
y & 0.020 \\
y & 0.020 \\
& 0.020\end{array}$ & $\begin{array}{ll}0 & 0.020 \\
0 & 0.020 \\
0 & 0.020 \\
6 & 0.020 \\
0 & 0.020 \\
0 & 0.020\end{array}$ \\
\hline
\end{tabular}




\section{ORISIM PIS:3 \\ OF FOOF QUALITY}

* Fear Fotor Corner seal Frotrusion

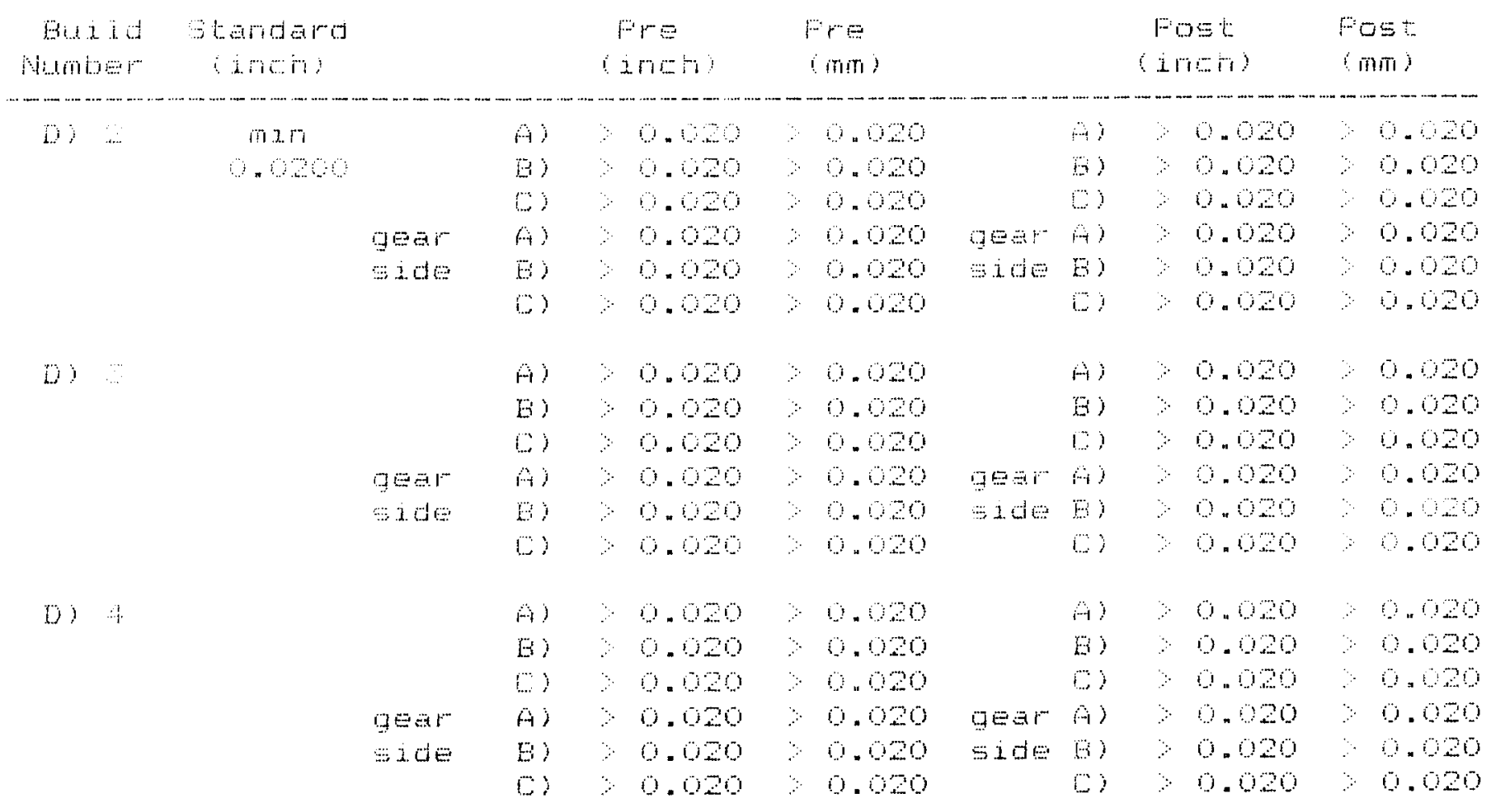


* Fear Fotor Corner Seal Weight

\begin{tabular}{|c|c|c|c|c|c|c|}
\hline \multicolumn{2}{|c|}{$\begin{array}{r}\text { Build } \\
\text { Number }\end{array}$} & & & $\begin{array}{l}F+g \\
(g)\end{array}$ & $\begin{array}{l}\text { Post } \\
\text { (a) }\end{array}$ & $\begin{array}{c}\text { Differer } \\
\text { Wre - Fos } \\
\text { (g) }\end{array}$ \\
\hline \multirow[t]{6}{*}{ Ai) } & 1 & & $A)$ & $\mathrm{NA}$ & $N A$ & NA \\
\hline & & & B) & $"$ & $"$ & $"$ \\
\hline & & & $\mathrm{Ci}$ & $"$ & " & " \\
\hline & & gear & A) & $"$ & $"$ & $" 1$ \\
\hline & & side & B) & 11 & $"$ & $1 "$ \\
\hline & & & C) & $" 1$ & $"$ & $"$ \\
\hline \multirow[t]{6}{*}{ B) } & 1. & & A) & 2.67 & 2.67 & 0.00 \\
\hline & & & B) & 2.68 & 2.67 & 0.01 \\
\hline & & & C) & 2.68 & 2.67 & 0.01 \\
\hline & & gear & A) & 2.67 & 2.69 & -0.02 \\
\hline & & side & B) & 2.70 & 2.69 & 0.01 \\
\hline & & & C) & 2.68 & 2.67 & 0.01 \\
\hline \multirow[t]{6}{*}{ (E) } & 1 & & A) & 2.67 & 2.07 & 0.00 \\
\hline & & & E) & 2.67 & 2.67 & 0.00 \\
\hline & & & 0 & 2.67 & 2.67 & 0.00 \\
\hline & & gear & $A)$ & 2.69 & 2.69 & 0.00 \\
\hline & & side & E) & 2.69 & 2.69 & 0.00 \\
\hline & & & C) & 2.67 & 2.67 & 0.00 \\
\hline
\end{tabular}

C) 2

\begin{tabular}{|c|c|c|c|c|}
\hline & A) & 2.67 & 2.67 & 0.00 \\
\hline & B) & 2.67 & 2.67 & 0.00 \\
\hline & C) & 2.67 & 2.67 & 0.00 \\
\hline gear & A) & 2.69 & 2.69 & 0.00 \\
\hline \multirow[t]{2}{*}{ side } & B) & 2.69 & 2.69 & 0.00 \\
\hline & C) & 2.67 & 2.67 & 0.00 \\
\hline
\end{tabular}

C) 3

$\begin{array}{llll}\text { A) } & 2.67 & 2.67 & 0.00 \\ \text { B) } & 2.67 & 2.66 & 0.01 \\ \text { C) } & 2.67 & 2.67 & 0.00 \\ \text { A) } & 2.69 & 2.69 & 0.00 \\ \text { B) } & 2.69 & 2.69 & 0.00 \\ \text { C) } & 2.67 & 2.67 & 0.00\end{array}$

C) 4

$\begin{array}{lllll} & \text { A) } & 2.67 & 2.67 & 0.00 \\ & \text { B) } & 2.66 & 2.66 & 0.00 \\ \text { Gear } & \text { C) } & 2.67 & 2.68 & 0.00 \\ \text { Side } & 2.69 & 2.67 & 0.02 \\ \text { B) } & 2.69 & 2.68 & 0.00 \\ & \text { C) } & 2.67 & 2.68 & 0.00\end{array}$

D) 1

$\begin{array}{lllll} & \text { A) } & \text { NA } & 2.64 & \text { NA } \\ & \text { B) } & " 1 & 2.66 & " 1 \\ \text { gear } & \text { A) } & 1 & 2.68 & " 1 \\ \text { side } & \text { B) } & 11 & 2.60 & " 1 \\ & \text { C) } & " & 2.67 & " 1\end{array}$


* Fear Fotor Corner Seal Weight **

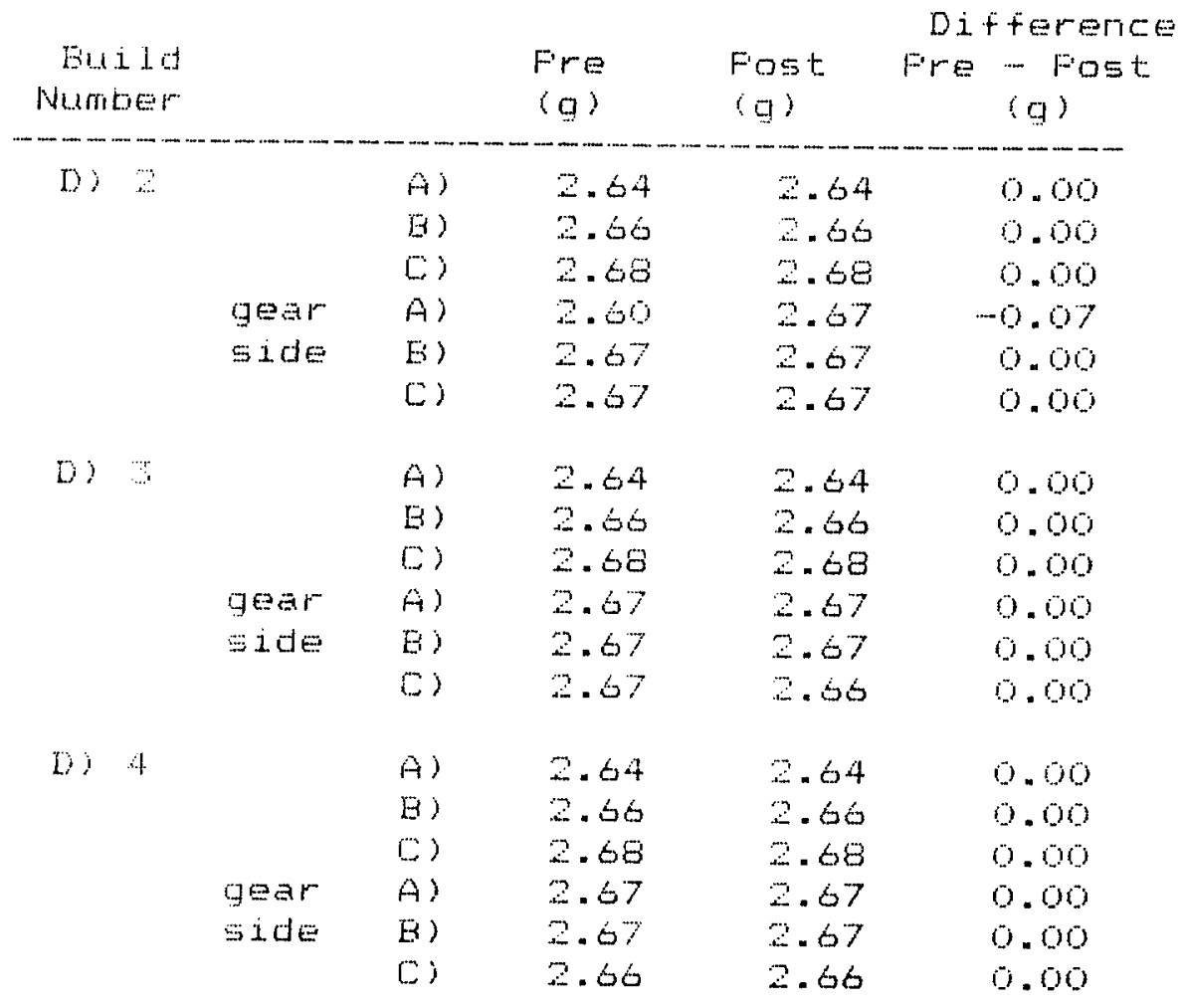

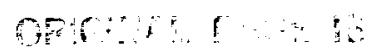

of pace 
1 


\section{APPENDIX F \\ COATED INTERMEDIATE \\ HOUSING DATA}

F -1 
COATED INTERMEDIATE HOUSING DATA

TABLE OF CONTENTS

Title

Page

Coated Intermediate Chart. . . . . . . . . . . . . . . . . F-3

Coated Intermediate Chart. . . . . . . . . . . . . . . . . . F-4

Coated Intermediate chart. . . . . . . . . . . . . . . . . . F-5

Coated Intermediate Housing Data . . . . . . . . . . . . . . . F-6

Coated Intermediate Housing Data . . . . . . . . . . . . . . . . . F-7

Coated Intermediate Housing Data . . . . . . . . . . . . . . F-8

Coated Intermediate Housing Data . . . . . . . . . . . . . . . . F-9 


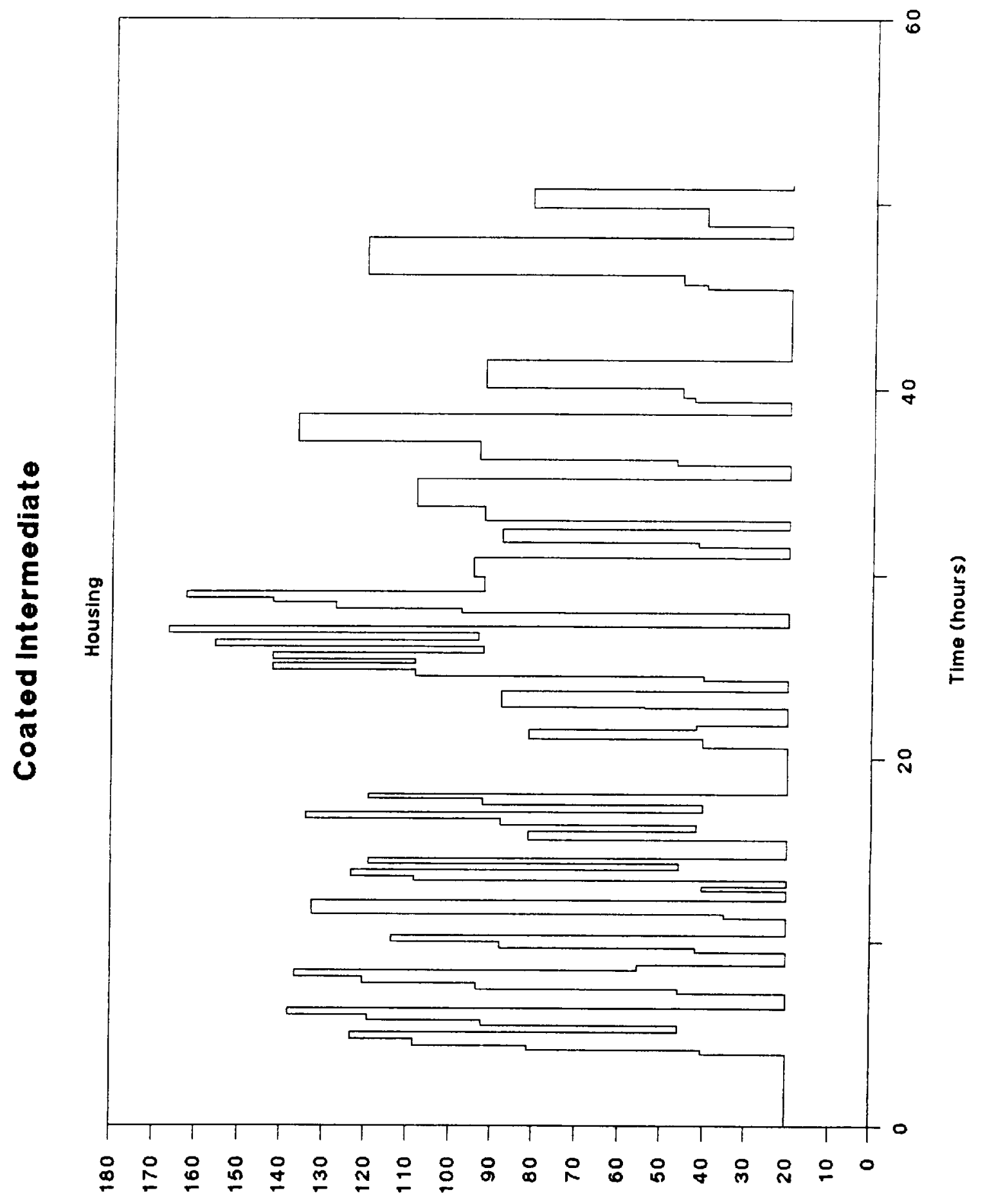

$\left(w_{* N}\right)$ enb.10L

F-3 


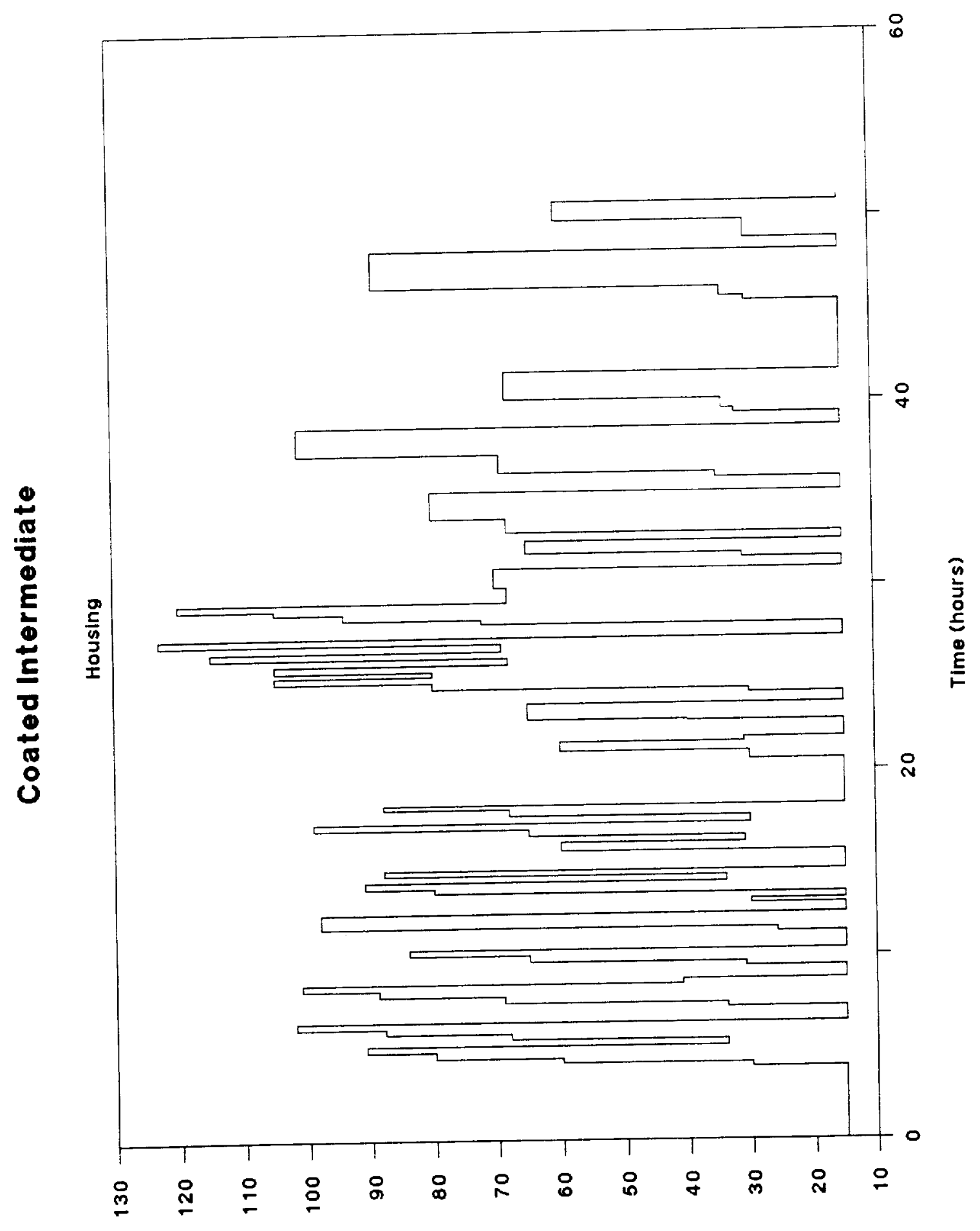

$(7 t * 591)$ enbsol

$F-4$ 


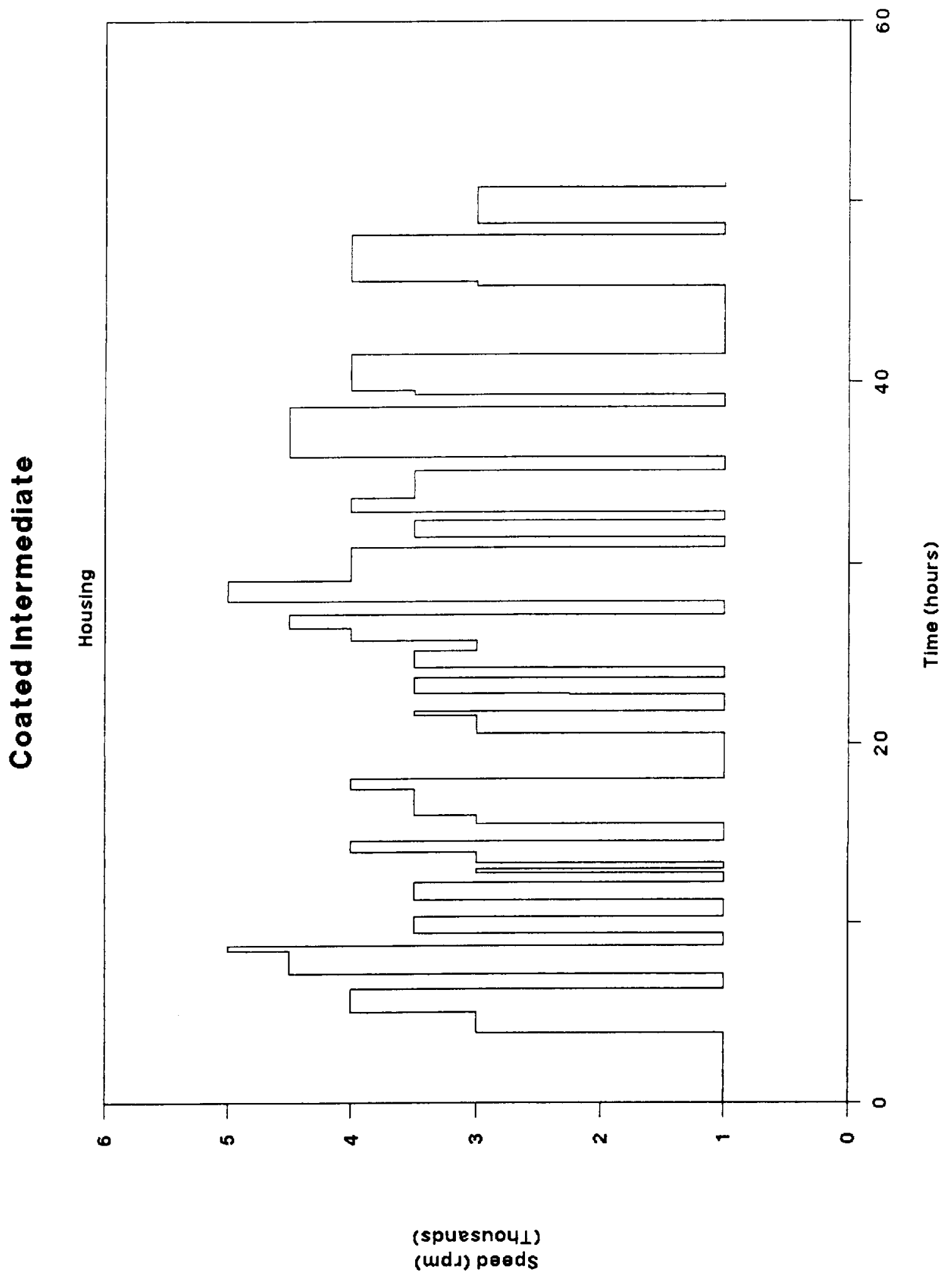

F-5 
$\overrightarrow{\mathrm{g}} \leq \overline{\underline{G}}$

$\overrightarrow{\mathrm{g}} \leq \overline{\mathrm{O}}$

离高

言言

$\leq$

$\leq \underline{\mathrm{g}}$

퐆

옳

虽苔离

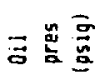

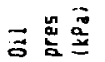

总哀高

몽

言品焉

言器

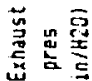

苯

产

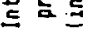

壱 气ํㅗㅀ

莒全意

崫 空

폽 흔

矛言喜

沓害要

咅

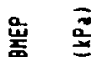

옳

옴 暜

产

至

梫

홀

:

蒙

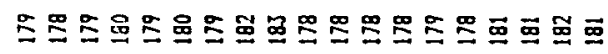

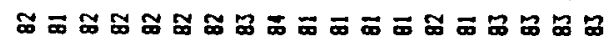

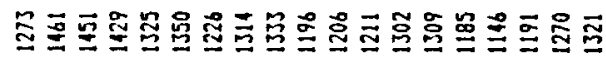

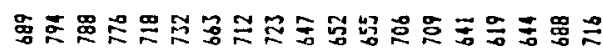

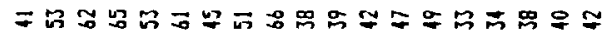
ㄷ

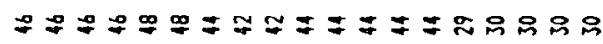

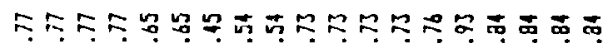
क

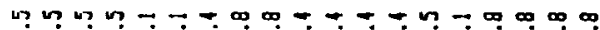

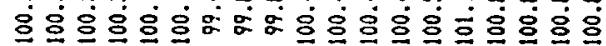

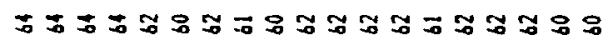

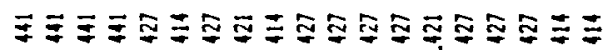

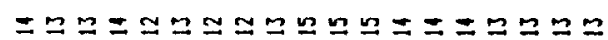

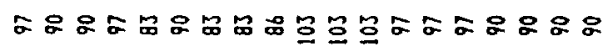
0000000000000000000 0000000000000000000

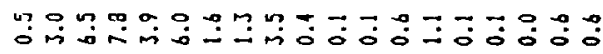

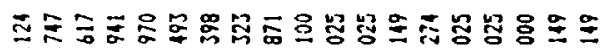

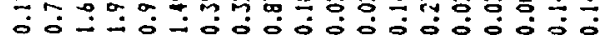

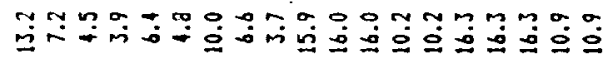

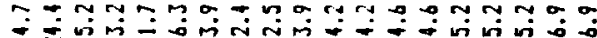

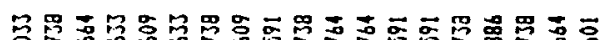

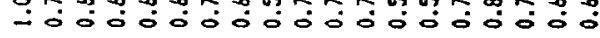

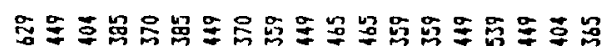

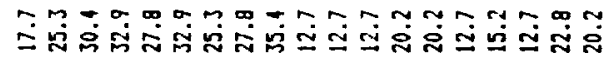

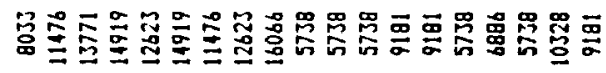

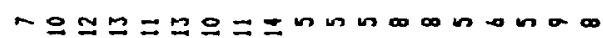

mu

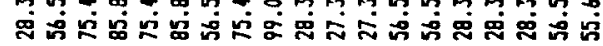

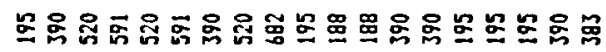

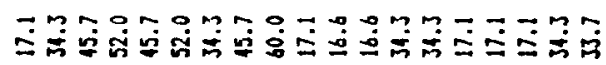

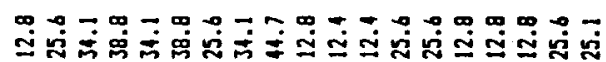

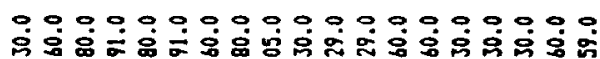

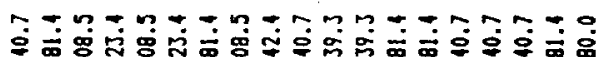

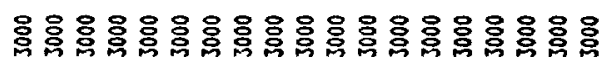

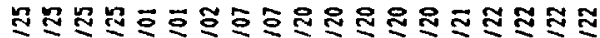

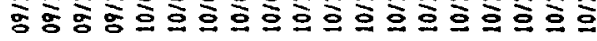

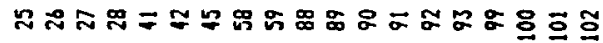

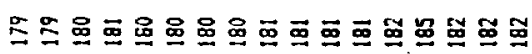
๓ ธ

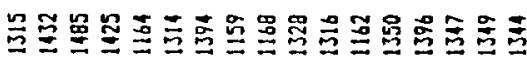

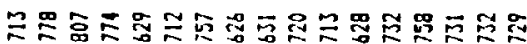

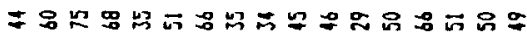

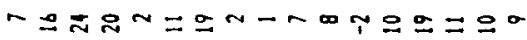

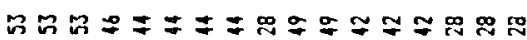

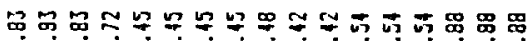

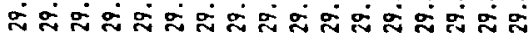

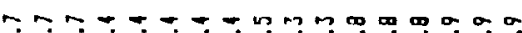

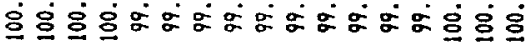

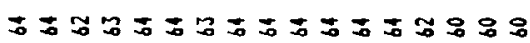

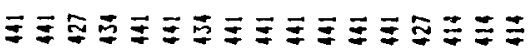

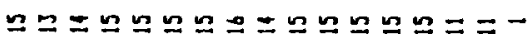

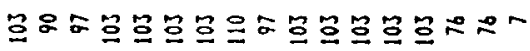
00000000000000000 00000000000000000

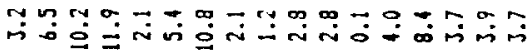

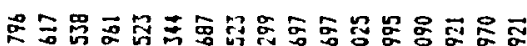
○一

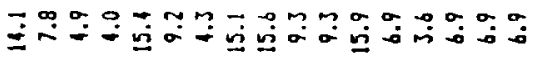

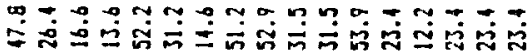

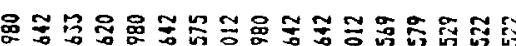

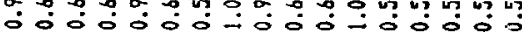

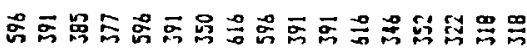

彳

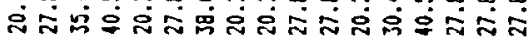

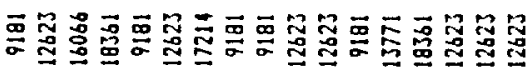

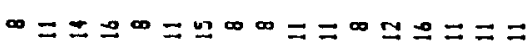

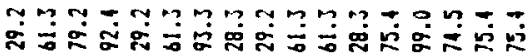

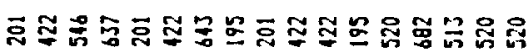

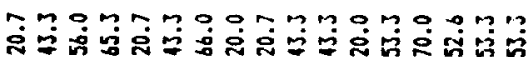

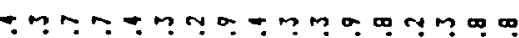

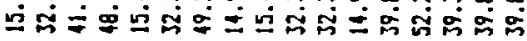

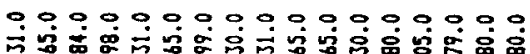

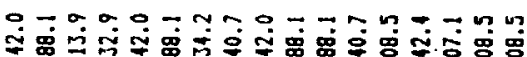

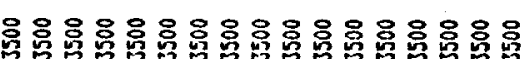

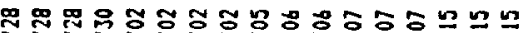

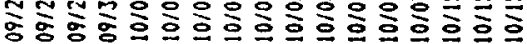

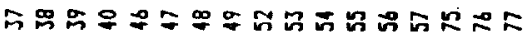

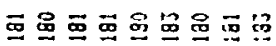

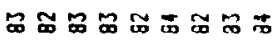

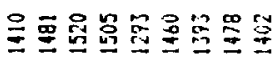

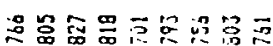

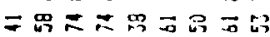
山

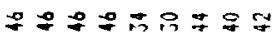

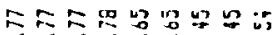

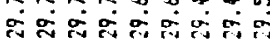

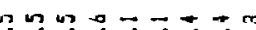

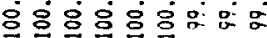

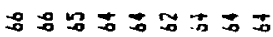

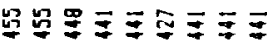
모우옴므믄

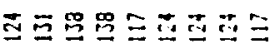

$0000000 \cdots$

000000000

$\because \dddot{0}$

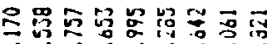

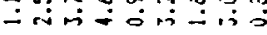

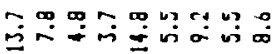

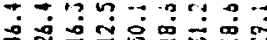

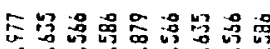

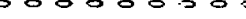

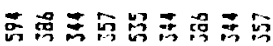

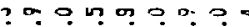

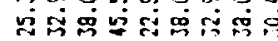

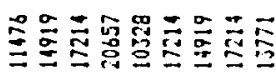
은ํํำำำ

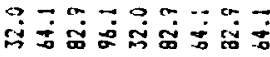

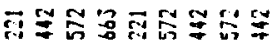
-

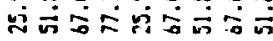
M000.10000

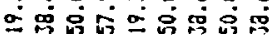
$000000=00$

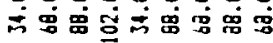

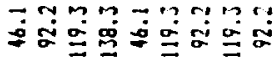

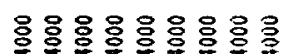

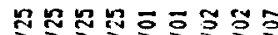

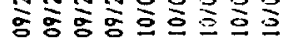

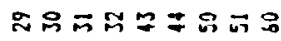




\section{ORIGINAL PRCE 13 \\ OF POGR QLALitY}

$\Xi \Xi$

累量可

$j=\underline{E}$

$\cong$

$\underline{E} \cong$

롤

总三五

旁 $\equiv \mathrm{g}$

을 프

을

$=\underline{\Xi}$

프

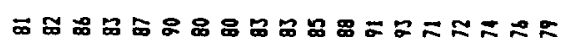

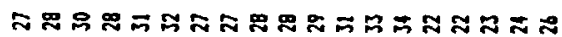

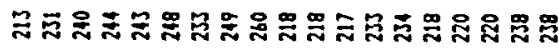

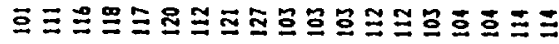

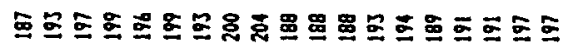

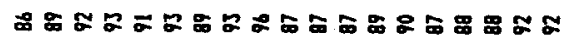

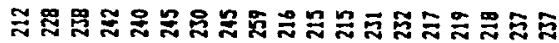

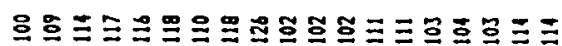

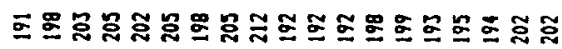

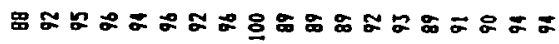

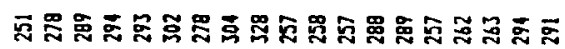

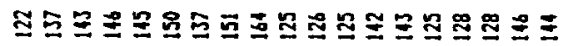

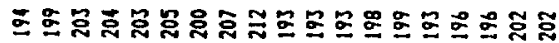

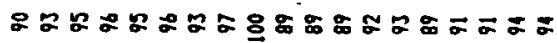

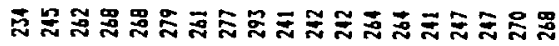

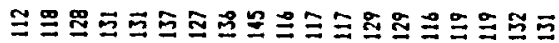

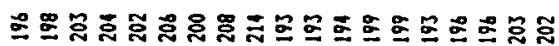

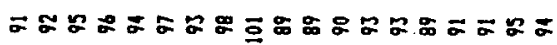

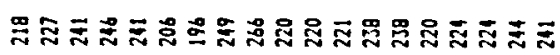

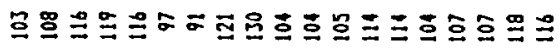

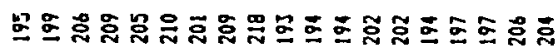

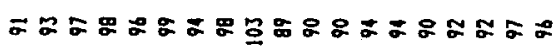

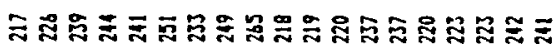

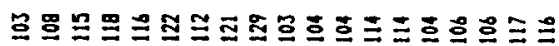

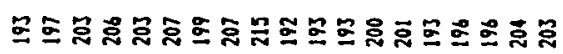

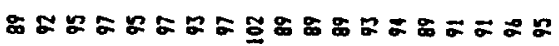

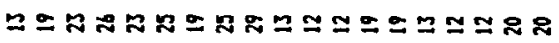

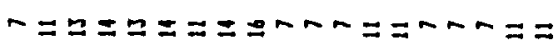

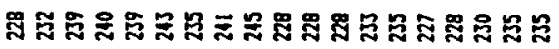

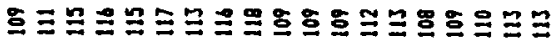

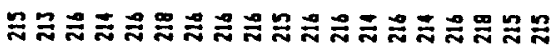

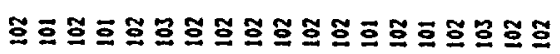

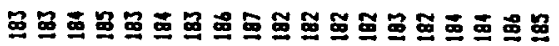

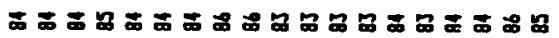

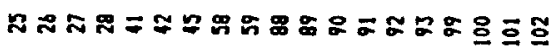

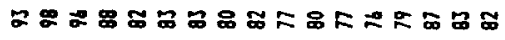

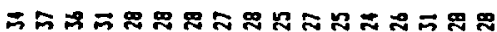

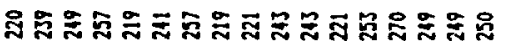

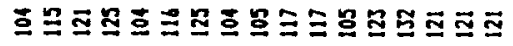

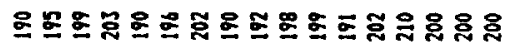

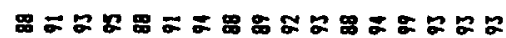

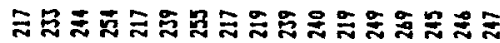

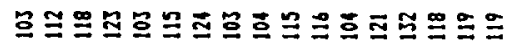

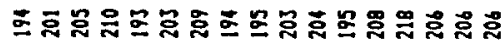

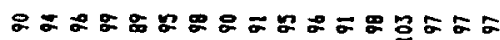

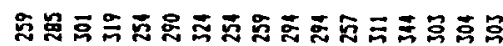

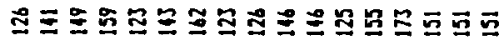

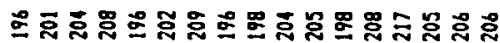

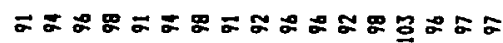

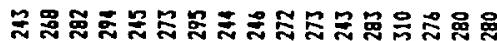

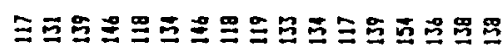

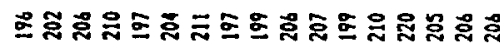

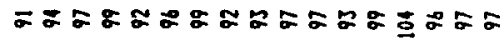

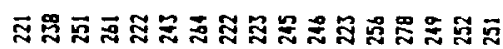

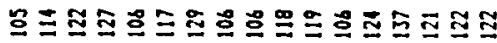

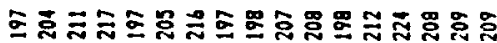

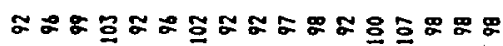

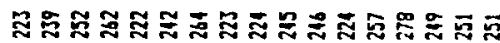

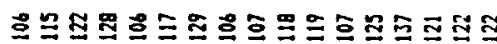

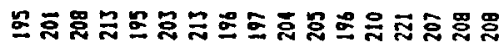

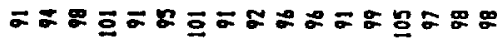

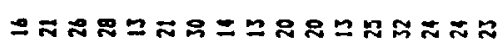

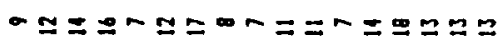
ลฐ̃

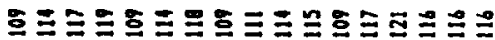

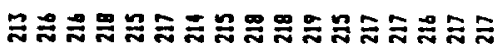

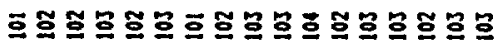

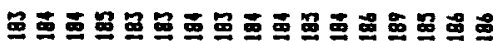

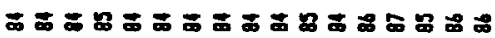

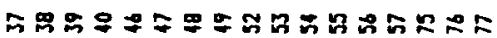

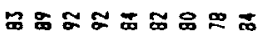

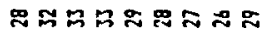

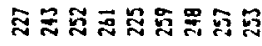

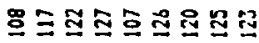

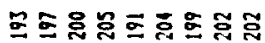
ロニるよ思るまる

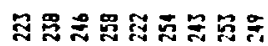

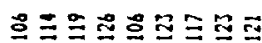

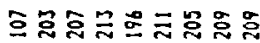

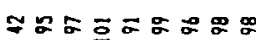

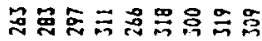

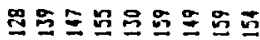

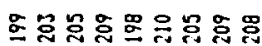

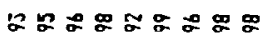

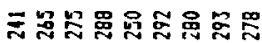
오ㅁㅗㅀㅗㅛ

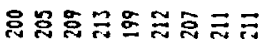

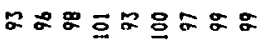

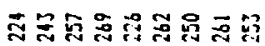

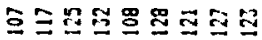

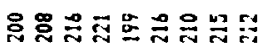

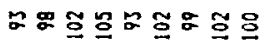

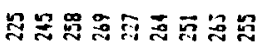

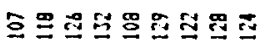

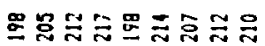

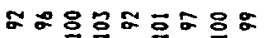

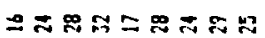

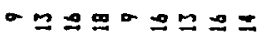

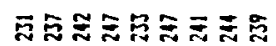

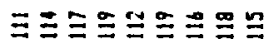

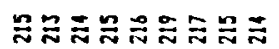

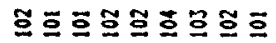

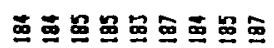

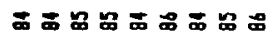

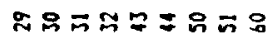




\begin{tabular}{|c|c|c|c|}
\hline$=$ & 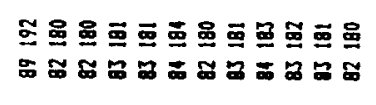 & 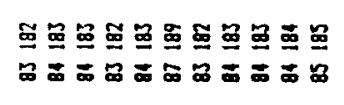 & 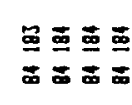 \\
\hline & 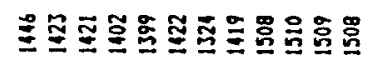 & 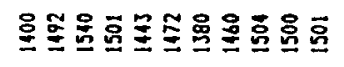 & 管总豆 \\
\hline & 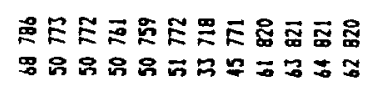 & 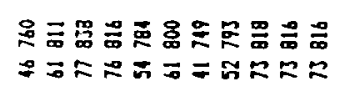 & 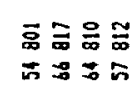 \\
\hline & 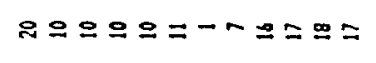 & $\infty \simeq \approx \approx \simeq \simeq n=a n \approx$ & $\simeq \approx \Phi=$ \\
\hline & 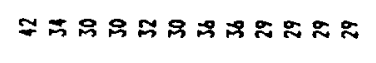 & 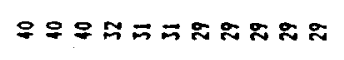 & $\vec{m}=\bar{m} \bar{m}$ \\
\hline & 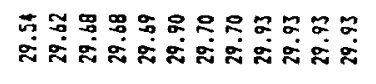 & 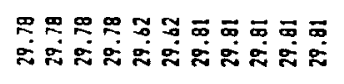 & 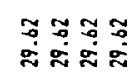 \\
\hline & 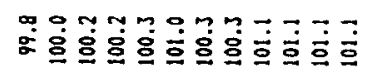 & 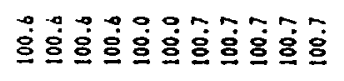 & 这宫富 \\
\hline & 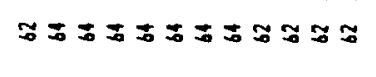 & 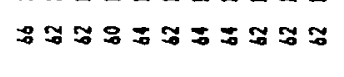 & $5: 58$ \\
\hline & ままほほほミまほミミミミ & 吕ミミうまミミミミミミ & ほまほす \\
\hline & 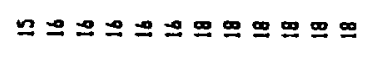 & 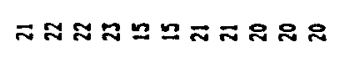 & 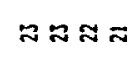 \\
\hline & $\stackrel{\Xi}{\varrho} \varrho \varrho \varrho \varrho \varrho \varrho \Xi \Xi \Xi \Xi \Xi \Xi$ & 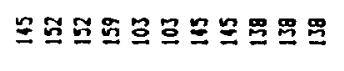 & 홓모모을 \\
\hline & 000000000000 & 00000000 & 0000 \\
\hline & 00000000 & 00000000000 & 0000 \\
\hline & 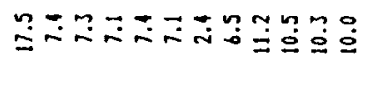 & 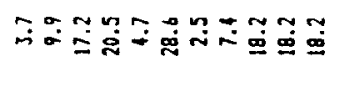 & 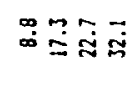 \\
\hline & 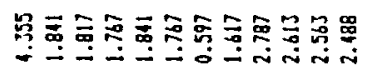 & 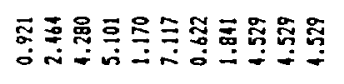 & 总总总罢 \\
\hline & 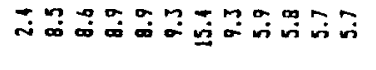 & 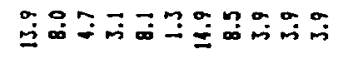 & 事こ品? \\
\hline & 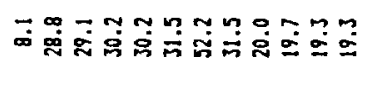 & 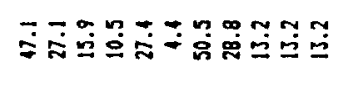 & 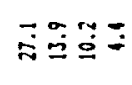 \\
\hline & 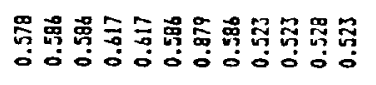 & 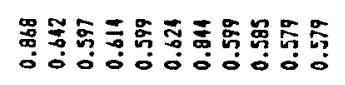 & 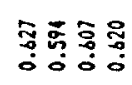 \\
\hline 童 & 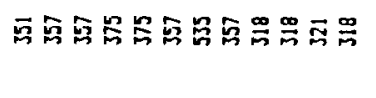 & 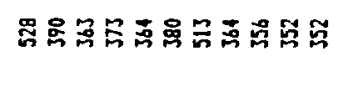 & 苾融品 \\
\hline & 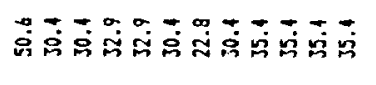 & 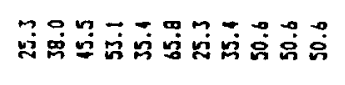 & $\ddot{\square} \ddot{\dot{8}}$ \\
\hline 8 & 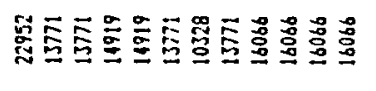 & 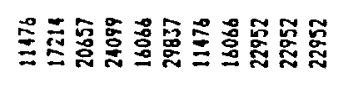 & 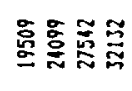 \\
\hline & $\therefore \simeq \simeq \because 2 \simeq \sigma \simeq \Sigma= \pm=$ & 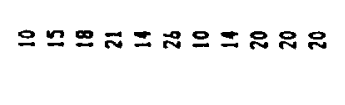 & $=\approx \pi$ 叫 \\
\hline $\bar{z}$ & 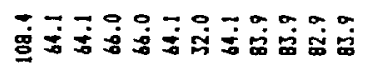 & 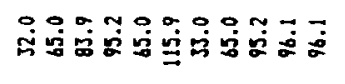 & 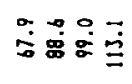 \\
\hline$=$ & 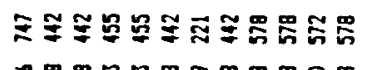 & 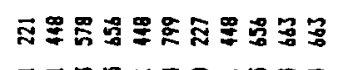 & 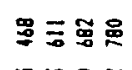 \\
\hline $\bar{a}$ & 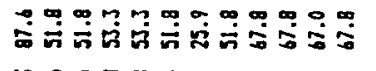 & 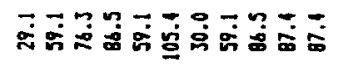 & 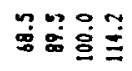 \\
\hline$\underline{\underline{3}}$ & 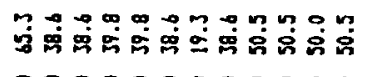 & 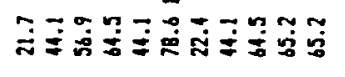 & $\overrightarrow{\bar{n}} \overline{\dot{s}}$ \\
\hline $\bar{E}$ & 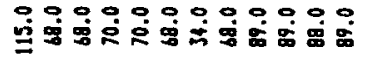 & 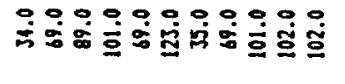 & 赵产通疋 \\
\hline ב & 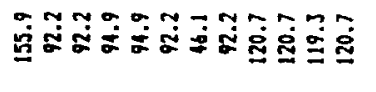 & 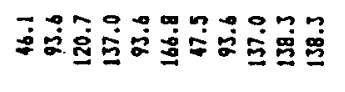 & 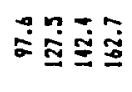 \\
\hline & 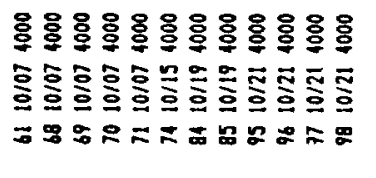 & 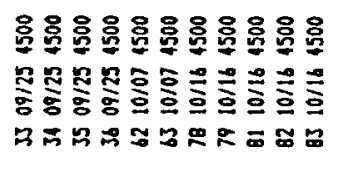 & 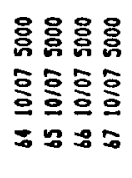 \\
\hline
\end{tabular}

F-8 


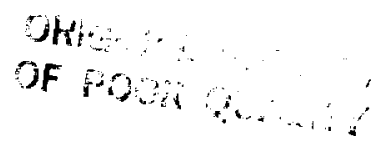

\begin{tabular}{|c|c|c|c|}
\hline 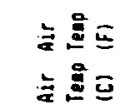 & 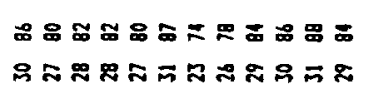 & 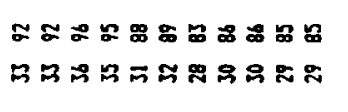 & 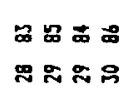 \\
\hline 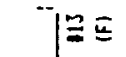 & 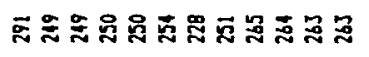 & 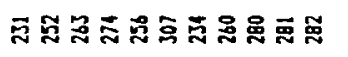 & 运总总总 \\
\hline$\cong$ & 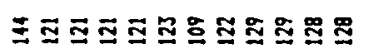 & $\Xi \cong \mathbb{Q}$ & 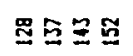 \\
\hline 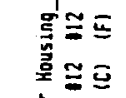 & 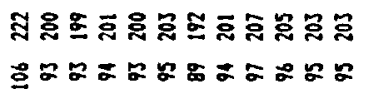 & 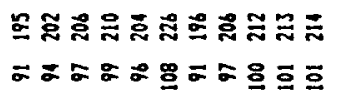 & $\begin{array}{l}\Xi \Xi \approx \pi \\
\approx \Xi \Xi \Xi\end{array}$ \\
\hline$\frac{\bar{g}}{\alpha} \equiv$ & 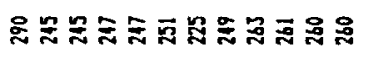 & 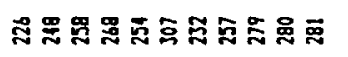 & 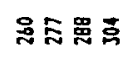 \\
\hline s & $\Xi \cong \cong \Xi \Xi \Xi \Xi \Xi \mathbb{\Xi} \Xi \Xi \Xi$ & 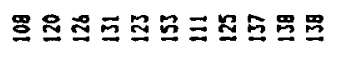 & $\Xi \Xi \cong \bar{\Xi}$ \\
\hline 을 & 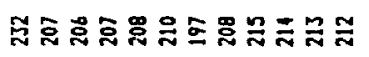 & 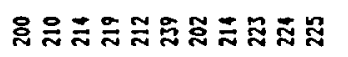 & $\underset{\sim}{\sim} \approx \mathbb{Z}: \mathbb{~}$ \\
\hline 은 & 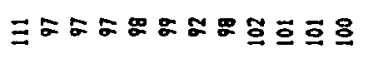 & 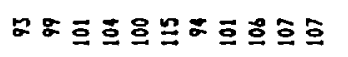 & 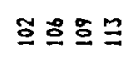 \\
\hline$=\Xi$ & 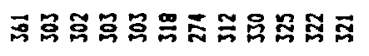 & 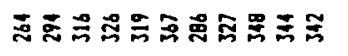 & 票畐点 \\
\hline$=9$ & 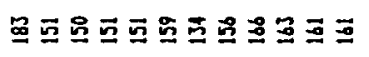 & 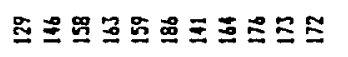 & 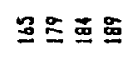 \\
\hline & 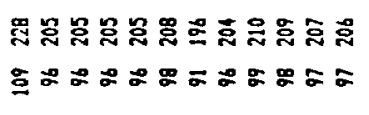 & 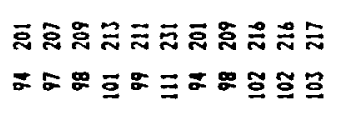 & 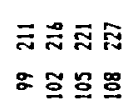 \\
\hline 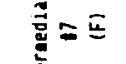 & 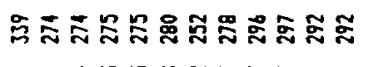 & 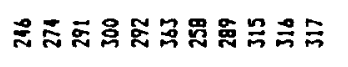 & 活云路品 \\
\hline$\overline{\underline{u}}=\Xi$ & 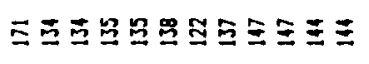 & 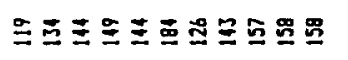 & $\equiv \Xi \underline{\underline{\Xi}}$ \\
\hline$=$ & 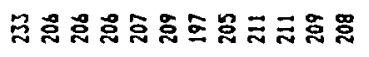 & $\stackrel{2}{2} \approx$ & 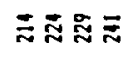 \\
\hline$=5$ & : & 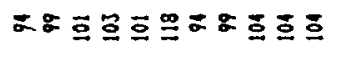 & $\Phi \underline{\Xi \Xi}$ \\
\hline 45 & 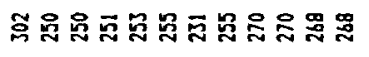 & 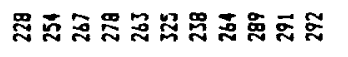 & 옹동묘요 \\
\hline$=3$ & 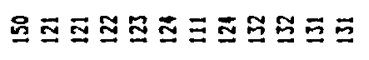 & 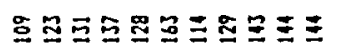 & $\Xi \Xi \Xi 9$ \\
\hline & 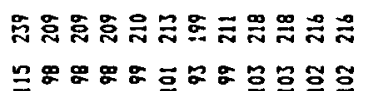 & 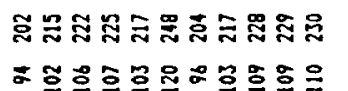 & 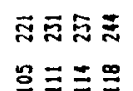 \\
\hline & 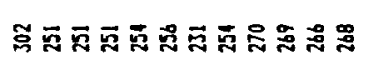 & 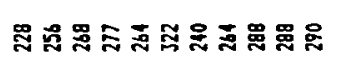 & 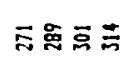 \\
\hline & 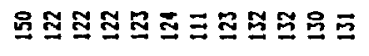 & 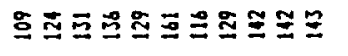 & 里早司可 \\
\hline & 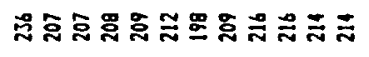 & 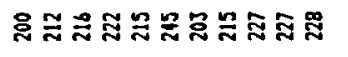 & 罢罚㤩辰 \\
\hline & 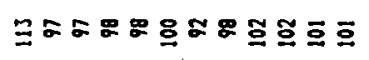 & 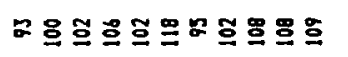 & $\Xi \Xi \Xi \Xi$ \\
\hline $\bar{z} \Xi$ & 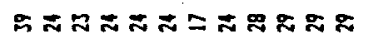 & 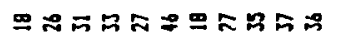 & gas \\
\hline $\bar{z}$ & 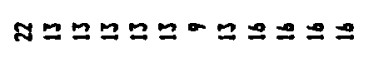 & 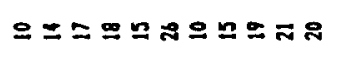 & $=0 \pi \pi$ \\
\hline & 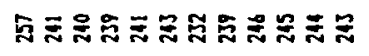 & 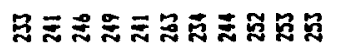 & 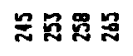 \\
\hline $\overrightarrow{3}$ & 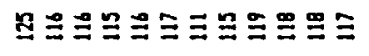 & 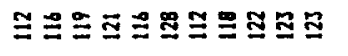 & $\Phi \Xi \Xi$ \\
\hline$\overline{3}$ & 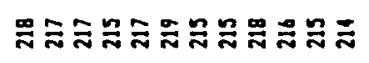 & 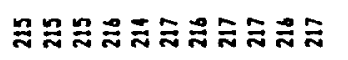 & $\approx \mathbf{2} \approx 0$ \\
\hline & 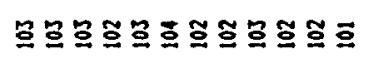 & 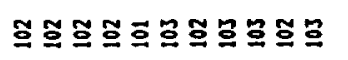 & 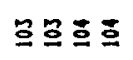 \\
\hline & 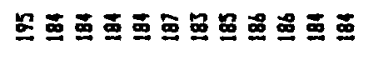 & 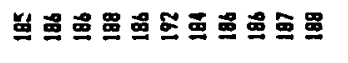 & $\underline{\mathbf{\Xi}} \mathbf{\mathbf { \Phi }} \mathbf{\mathbf { \Phi }} \mathbf{\Phi}$ \\
\hline & 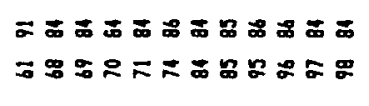 & 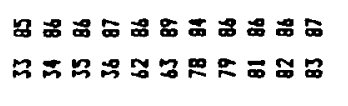 & $\begin{array}{l}\$ 280 \\
5: 50\end{array}$ \\
\hline
\end{tabular}


1 


\section{APPENDIX G - I \\ UNDENSIFIED COATED \\ ROTOR DATA}

$C-I-1$ 
UNDENSIFIED COATED ROTOR DATA

TABLE OF CONTENTS

Title

Page

Undensified Coated Chart. . . . . . . . . . . . . G-I-3

Undensified Coated Chart. . . . . . . . . . . . . . G-I-4

Undensified Coated chart. . . . . . . . . . . . . . G-I-5

Undensified Coated Rotor Data . . . . . . . . . . . G-I-6

Undensified Coated Rotor Data . . . . . . . . . . . . . G-I-7

Undensified Coated Rotor Data . . . . . . . . . . . G-I-8

Undensified Coated Rotor Data . . . . . . . . . . . G-I-9

Undensified Coated Rotor Data . . . . . . . . . . G-I-10

Undensified Coated Rotor Data . . . . . . . . . . . . G-I-11 


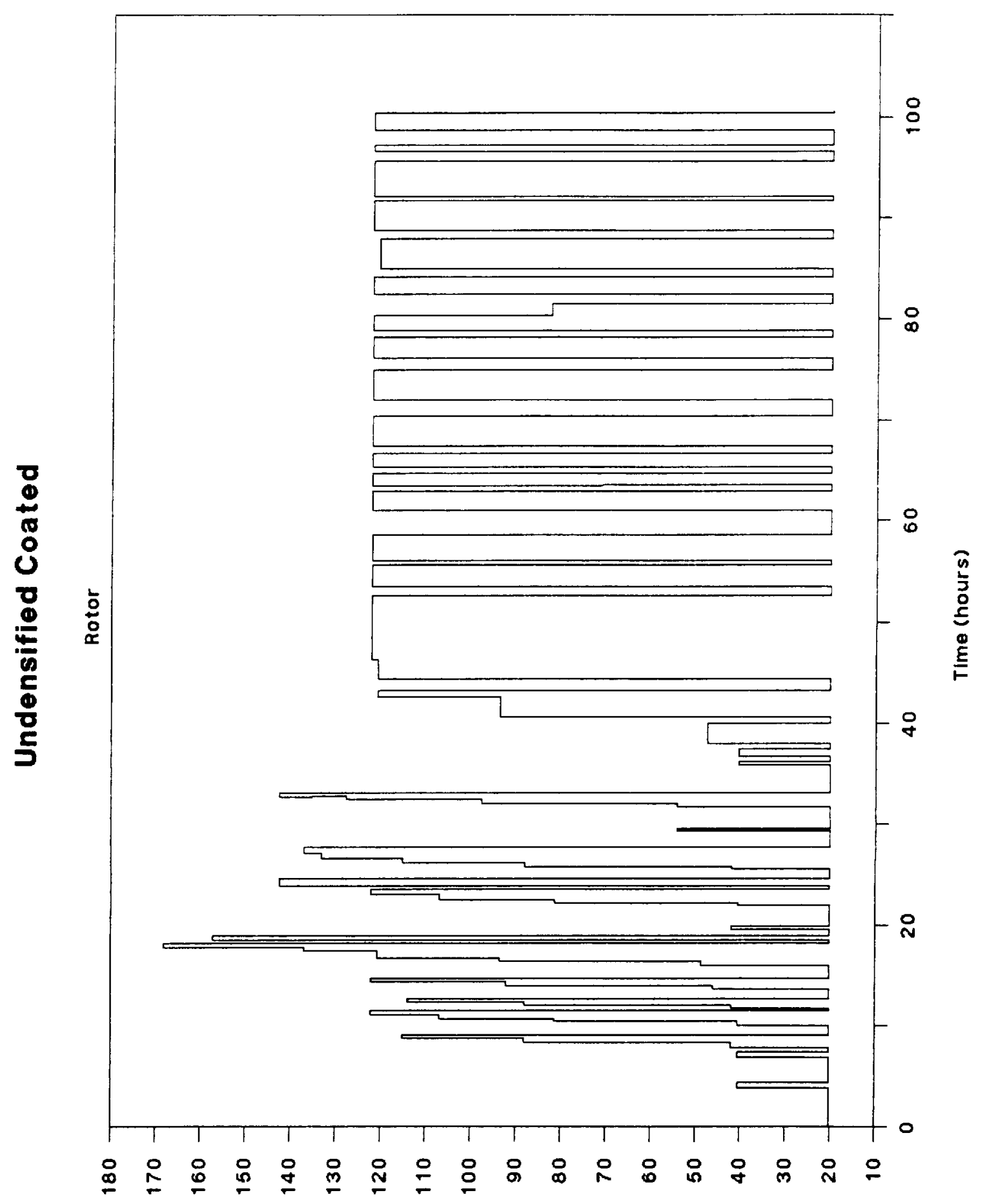

$\left(w_{* N}\right)$ enb $10 \perp$

G-I -3 


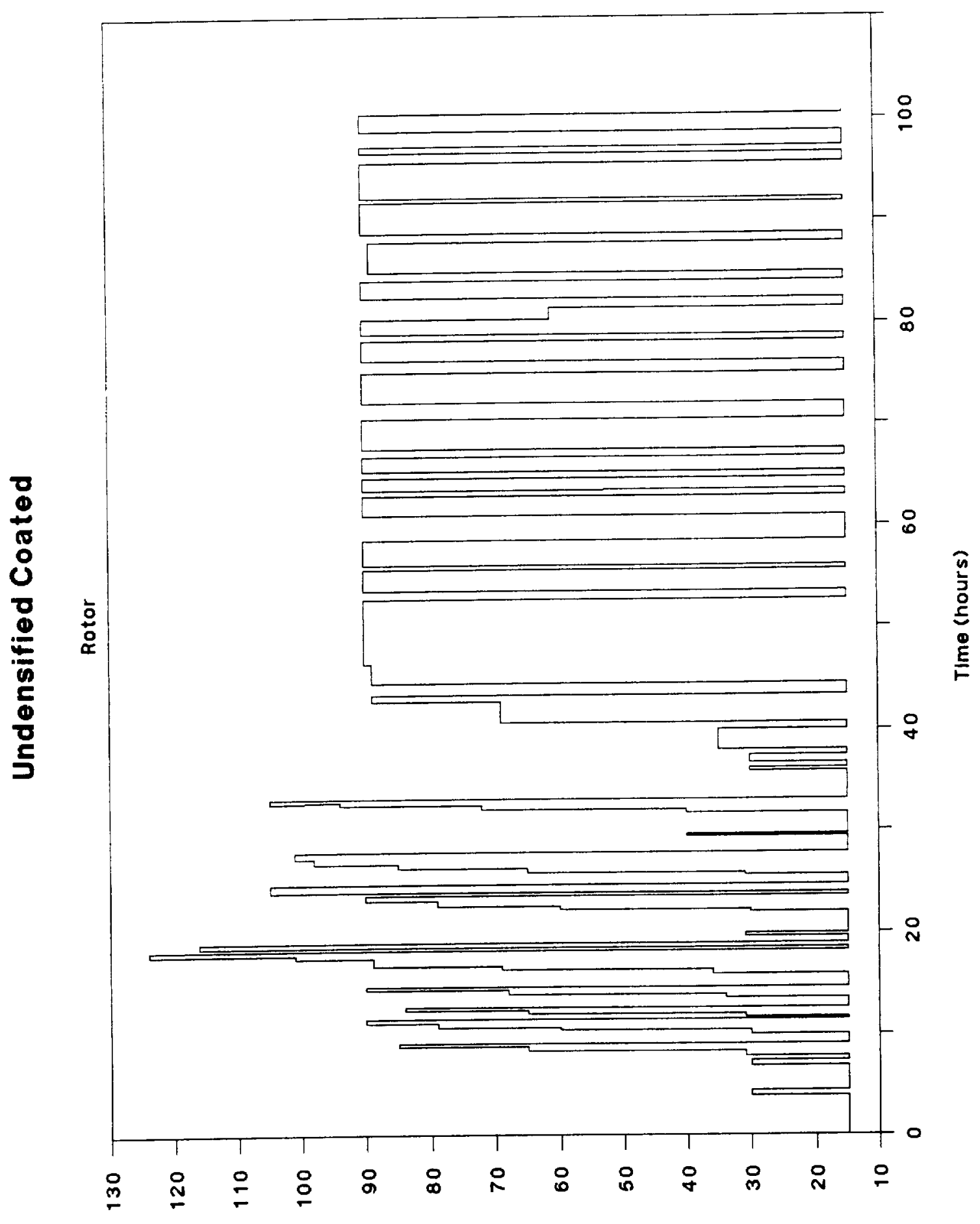

(tt*sq1) enbsol

$G-I-4$ 


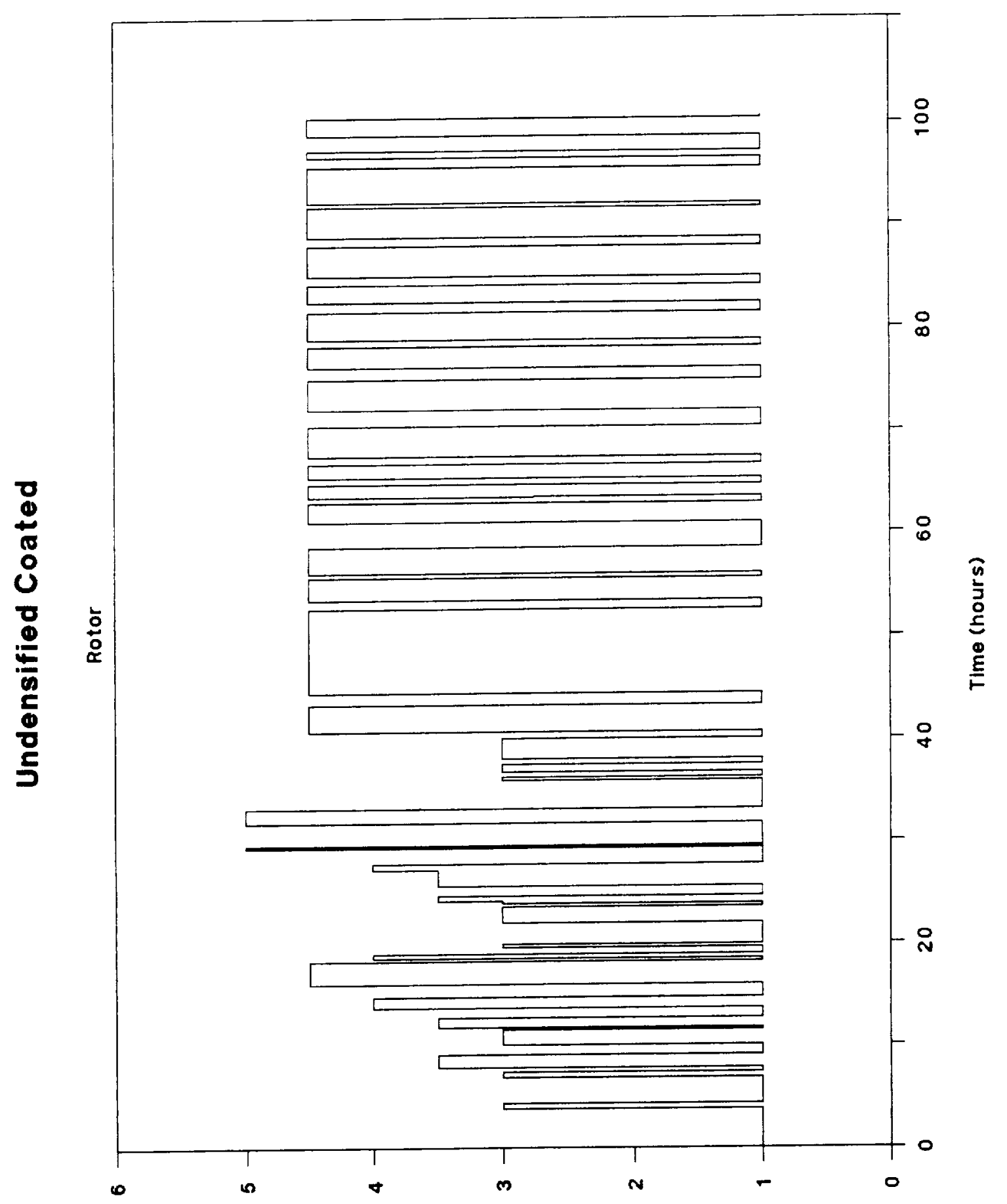

(spuesnouL)

(udd) peeds

$$
\text { G-I - } 5
$$




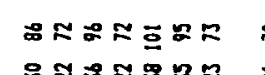
คสะสำด

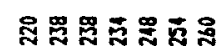

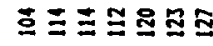

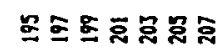
こミミよるまる

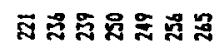

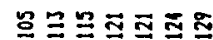

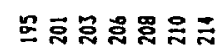

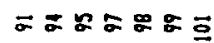

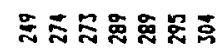

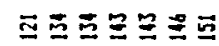

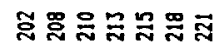

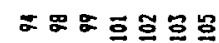

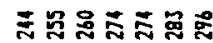

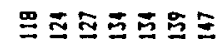

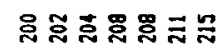
まよます思灾

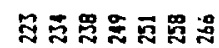
$\Xi \cong \Xi \Xi \Xi \mathbb{2} \cong$

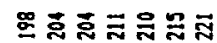

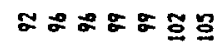

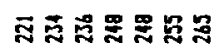

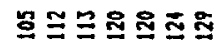
อำำำำลำ の゙こニよする

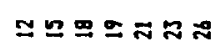
- $-9=\simeq \geq=$

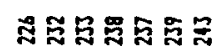

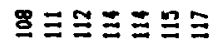

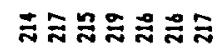
ㅍㅗㅀㅗำ

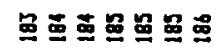

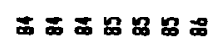

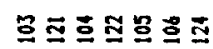

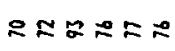
西苗

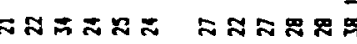

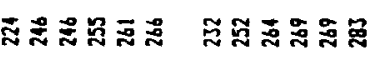

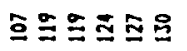

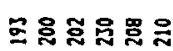
ธ2まㅇㅇㅠ.

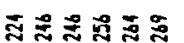

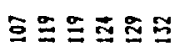
옹ㅊ츰 ๙えまま方

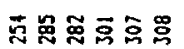

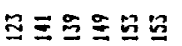

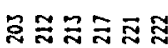
오호로오

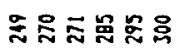

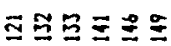

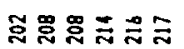

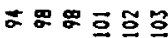

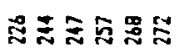

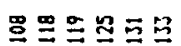

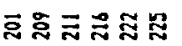
요호

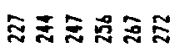
国回可可昌

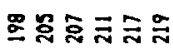
そょまする $\simeq ニ \Omega \Omega \approx \Sigma$ $\sim a== \pm=$

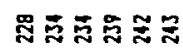
$\Phi \cong \cong \cong \Xi \Xi$ 웇ㅎㅀㅇㅝ

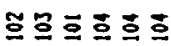

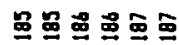
๓๐

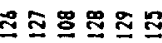

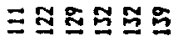

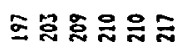

둥영

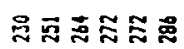

오으믈

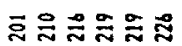

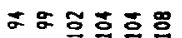

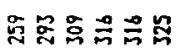

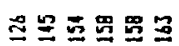

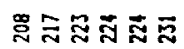

을오호

충요

프로프모

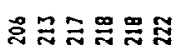

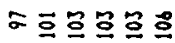

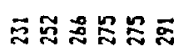

三포으모ㅁㅗㅡ

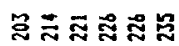

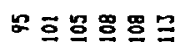

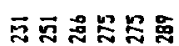

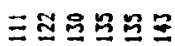

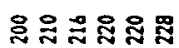

250 吉吉

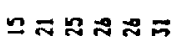

○ェニニニニ

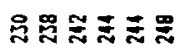
오三三国용

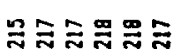

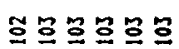

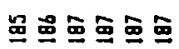

ณ 응
호오오

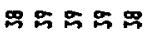

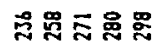

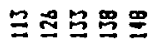

호스류

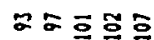

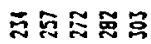
포모호모

호쵸죠

으므요을

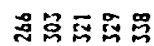

옥프모응

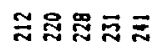

음모을

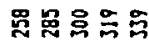

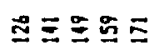

竞气

농흐

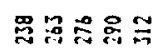

포으료

อ哩界末

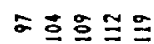

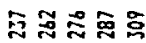

胥影的

อำส

옹ํ유

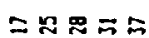

$\because=ュ ニ \approx$

오ㅇㅖㅛ

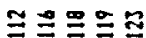

느ㄴㅡㅠ

도오ำ

$\underline{\mathbf{m}} \mathbf{\underline { \mathbf { m } } \mathbf { \Xi }} \mathbf{\Xi} \mathbf{\Xi}$

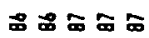

$\cong \equiv \Xi \Xi \Xi$

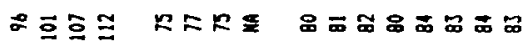

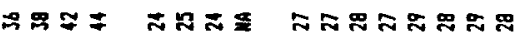

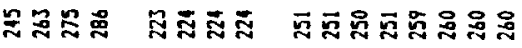

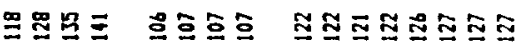

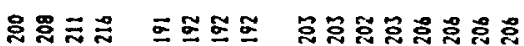

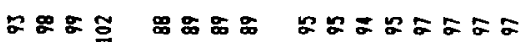

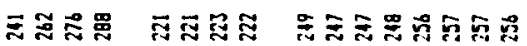

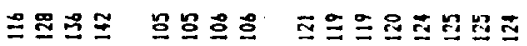

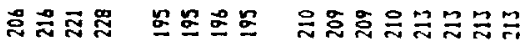

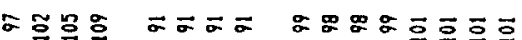

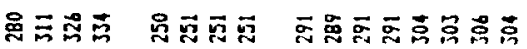

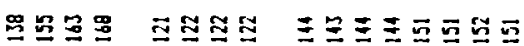

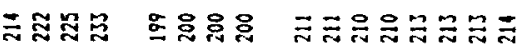

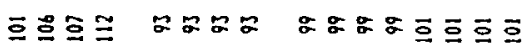

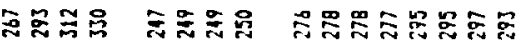

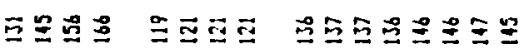

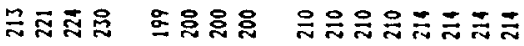

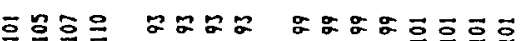

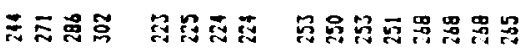

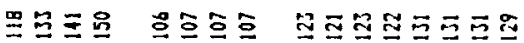

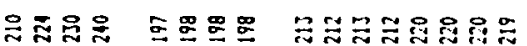

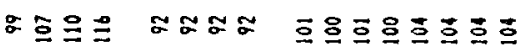

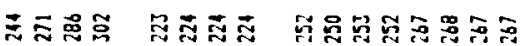

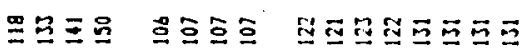

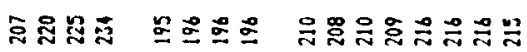

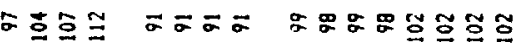

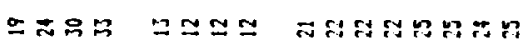

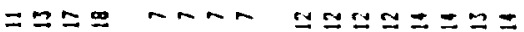

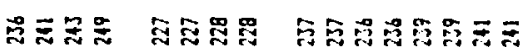

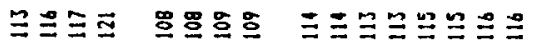

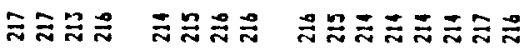

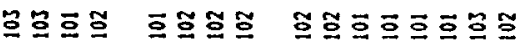

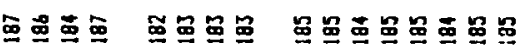

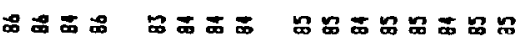

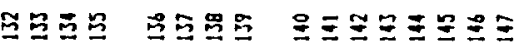




\begin{tabular}{|c|c|c|c|c|c|c|c|}
\hline $\bar{g}=\bar{\Xi}$ & 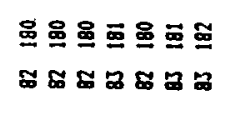 & 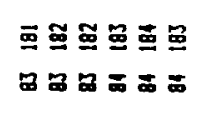 & 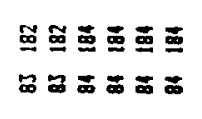 & 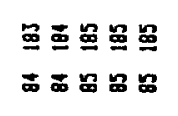 & 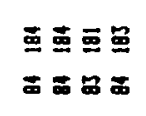 & 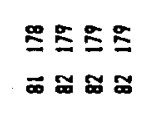 & 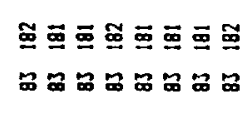 \\
\hline & 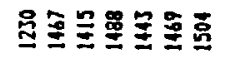 & 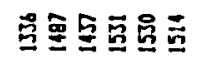 & 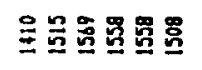 & 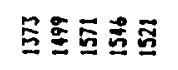 & : & 互里豆豆 & 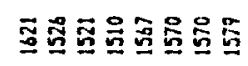 \\
\hline & 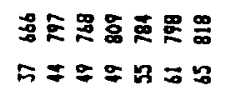 & 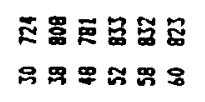 & 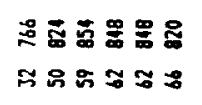 & $\begin{array}{l}5: 5 \Xi \Xi \\
=585\end{array}$ & 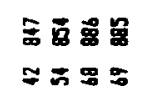 & $\approx$ & 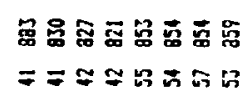 \\
\hline & 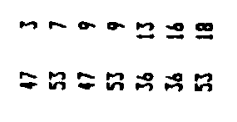 & 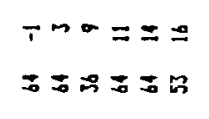 & $\begin{array}{l}\circ 0=2=0 \\
\sin 5=9\end{array}$ & 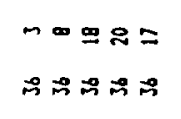 & $\begin{array}{l}\circ \approx \Omega \pi \\
\approx \approx \approx \pi\end{array}$ & 무요 & $==$ \\
\hline 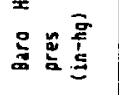 & 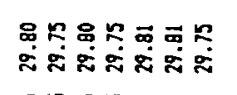 & 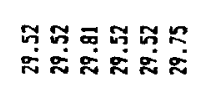 & 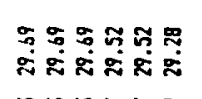 & 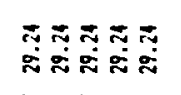 & & & \\
\hline & 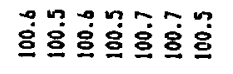 & :亏亏 & 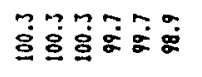 & 产产产产 & 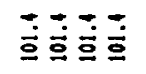 & 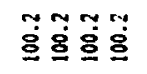 & 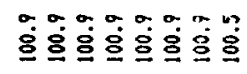 \\
\hline & $\sim \sim$ & $5555: 3$ & 55335 & 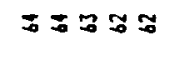 & $: 555$ & $5: 55$ & -7 \\
\hline & ちミミミミミ & $E \Xi$ & $5 \Xi$ & ますます & 号界引ミ & ほミミミ & 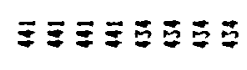 \\
\hline & คேッロニニニ & $0 n=n n=$ & $\mathbf{\Phi} \mathbf{\Phi}=$ & 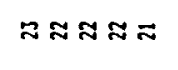 & $\approx \approx$ & - & $\approx \approx \approx$ \\
\hline & 몽응 & ఏอョミอョぇ & $\Xi \Xi \Xi \Xi \Xi \Xi$ & 또ำำ & $\Xi \Xi \Xi$ & $\Xi \Xi \Xi \Xi$ & 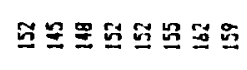 \\
\hline & 00 & 000000 & 00 & 00 & 0000 & 0000 & 000 \\
\hline & 000000 & 0000 & 0 & 0 & 0000 & 0000 & 00 \\
\hline & 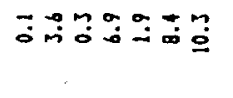 & 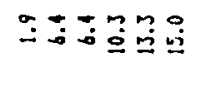 & 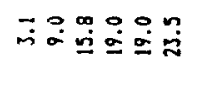 & 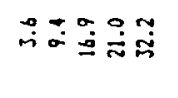 & نَّ & $\tilde{i} \underset{i}{ } \underset{i}{ }$ & 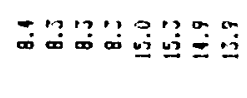 \\
\hline & 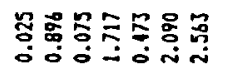 & 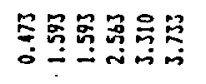 & 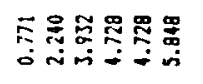 & 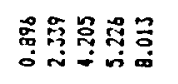 & 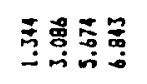 & 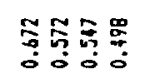 & \\
\hline & 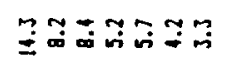 & 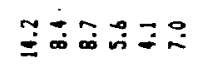 & 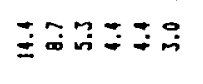 & 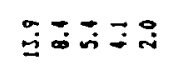 & $\dot{m}$ & 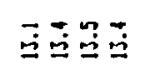 & 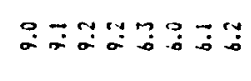 \\
\hline & 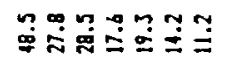 & $\dot{s}$ & 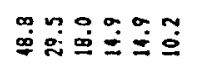 & 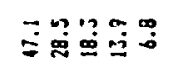 & 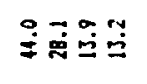 & 安客宫 & \\
\hline & 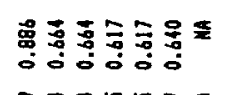 & $\ddot{m} \approx \approx-050$ & 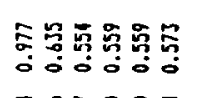 & & & & \\
\hline 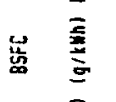 & 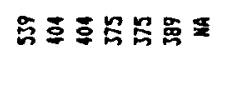 & 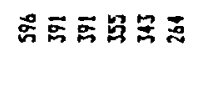 & 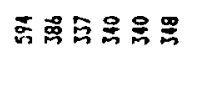 & 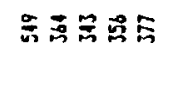 & 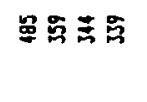 & 㤩㤩点点 & 5 \\
\hline $\bar{g}$ & 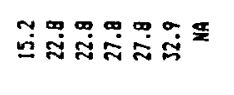 & 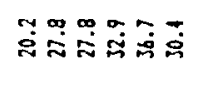 & 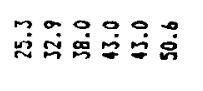 & 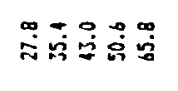 & 㑒象畐总 & 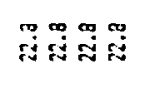 & 宫点: \\
\hline$\frac{\underline{s}}{\underline{s}}$ & 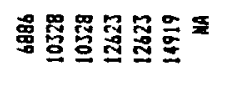 & 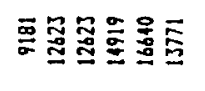 & 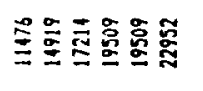 & 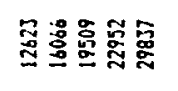 & 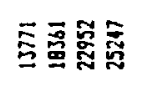 & 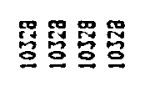 & 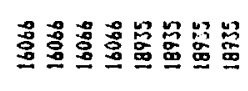 \\
\hline$\vec{a}=3$ & $\cdots a==2 x$ & $\infty==209$ & $9=2=28$ & $= \pm ニ 8 \approx$ & $\simeq 28 \pi$ & $\infty \infty$ & $---\cdots$ \\
\hline$\equiv$ & 年 & 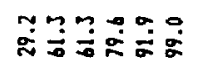 & 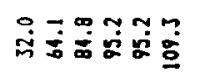 & 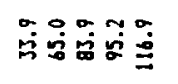 & 官宫宧 & 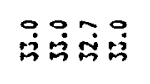 & 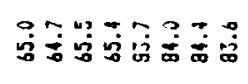 \\
\hline$\stackrel{\bar{a}}{=}$ & 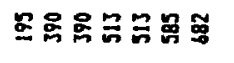 & 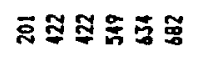 & 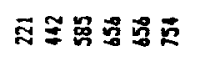 & 巨里思品 & : & & $\frac{P}{q}$ \\
\hline s & 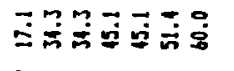 & 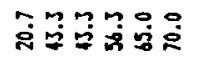 & 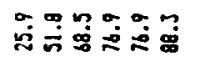 & 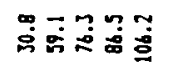 & 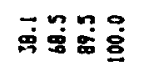 & 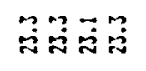 & 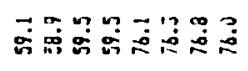 \\
\hline$=$ & 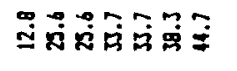 & 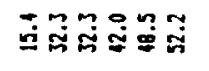 & 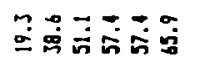 & & 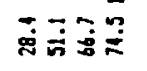 & $\stackrel{\Xi}{\Xi} \stackrel{\Xi}{=}$ & 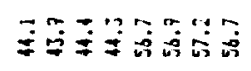 \\
\hline 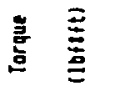 & 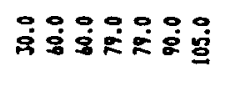 & 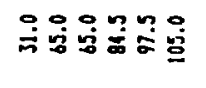 & 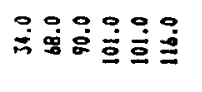 & 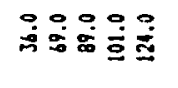 & 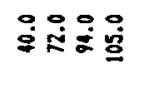 & 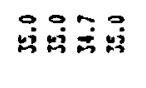 & 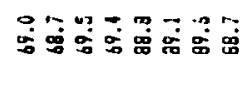 \\
\hline $\mathrm{z}$ & 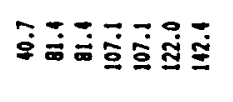 & 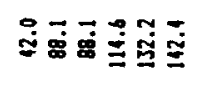 & 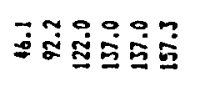 & 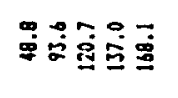 & 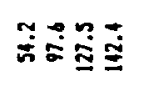 & $\stackrel{9}{=}=$ & 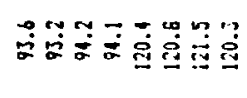 \\
\hline 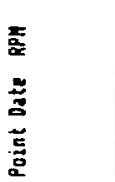 & 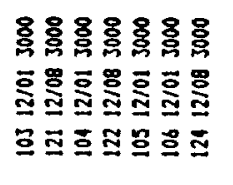 & 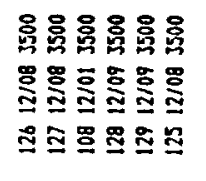 & 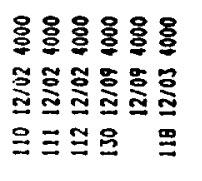 & 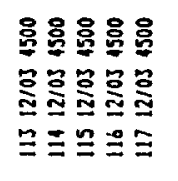 & 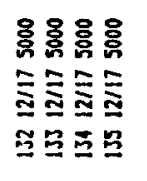 & 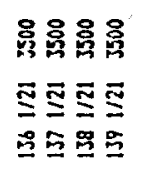 & 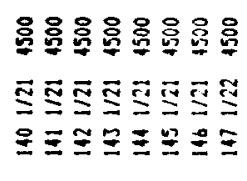 \\
\hline
\end{tabular}

$$
\text { G-I-7 }
$$


$\overrightarrow{\mathrm{g}}=\underline{\Xi}$

$\overline{\mathrm{g}} \leq \underline{\mathrm{g}}$

畐高正

ํㅗㄴ

$\leq \Xi$

$\leq \Xi \bar{\Xi}$

急

ำ

号高

西高

咅悹

总点高

总高

言高要

言高总

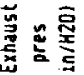

商

$\bar{x}$

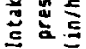

藏高

㬅豆

㟧 焉

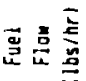

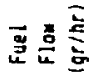

혼

兽

总

옳

옿 홓

娄

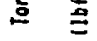

丞

产

莡

䓂

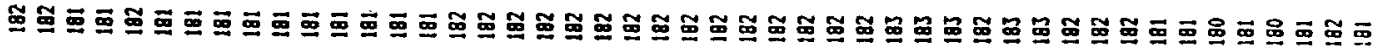

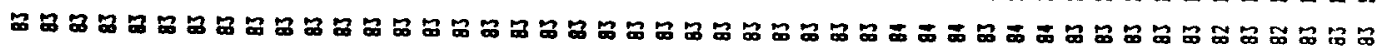

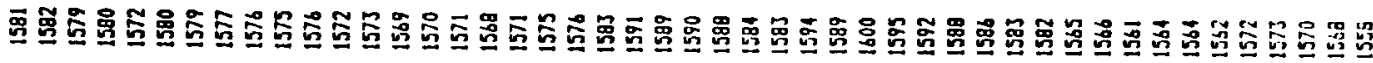

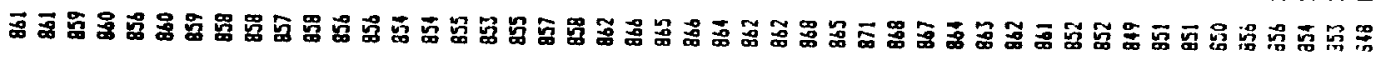

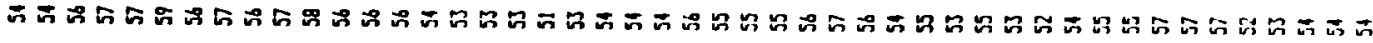

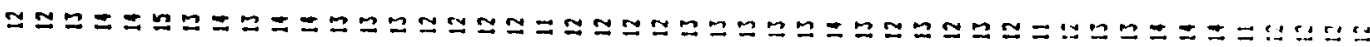

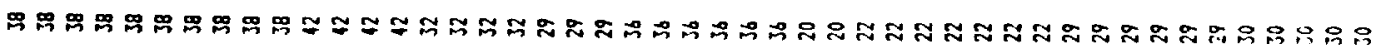

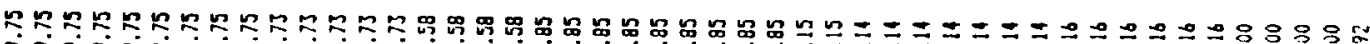

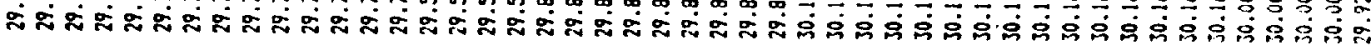

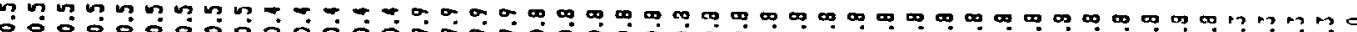

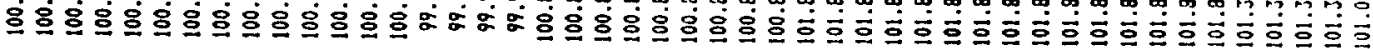

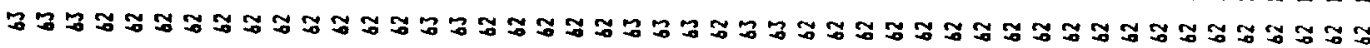

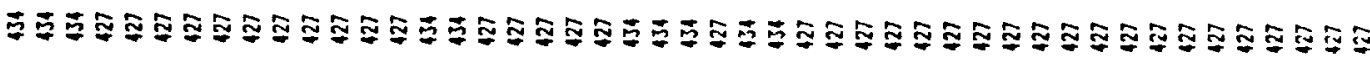

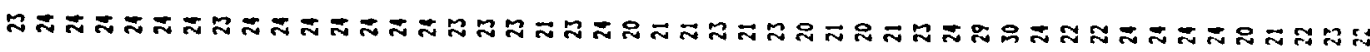

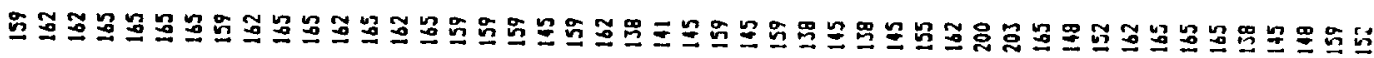
00000000000000000000000000000000000000000000000 00000000000000000000000000000000000000000000000

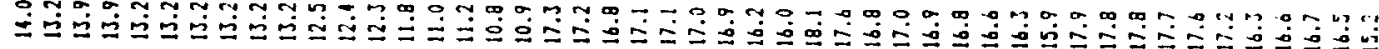

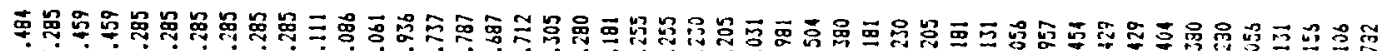

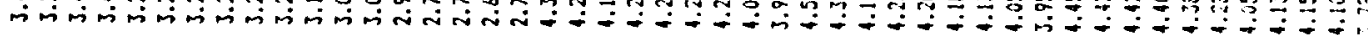

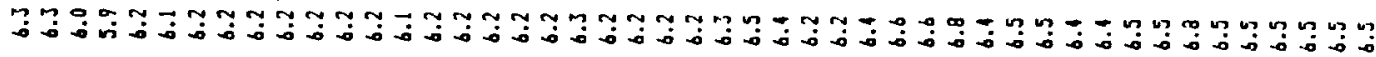

Mmmo M

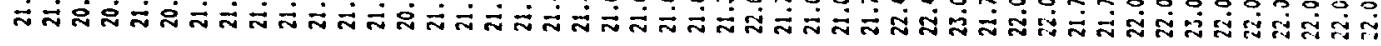

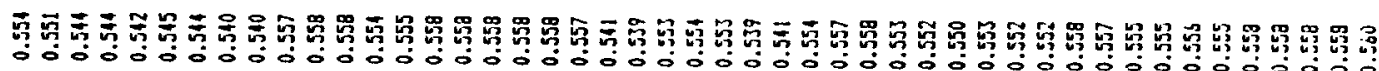

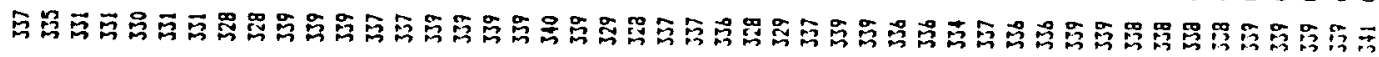

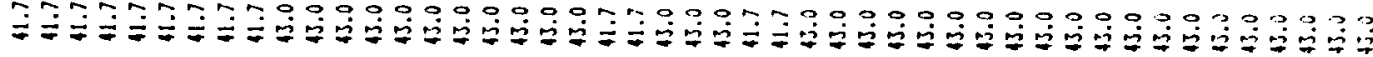

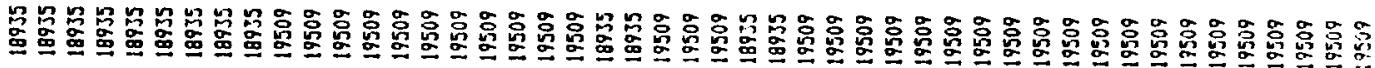

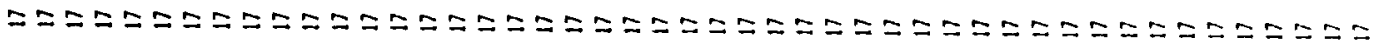

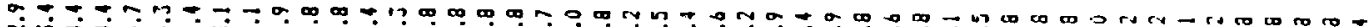

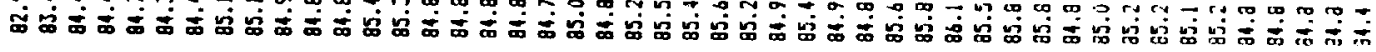

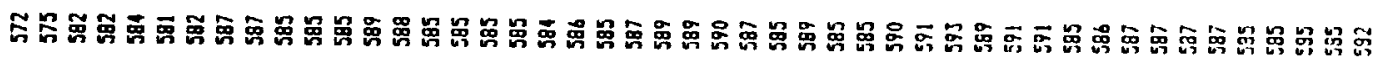

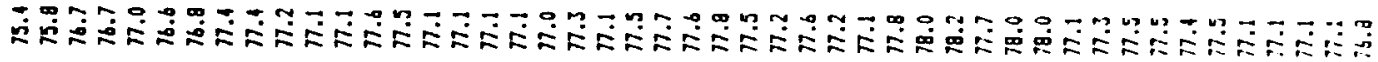

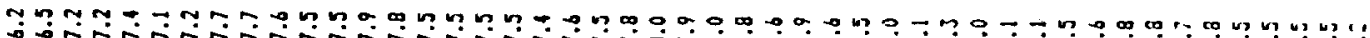

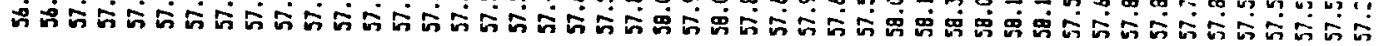

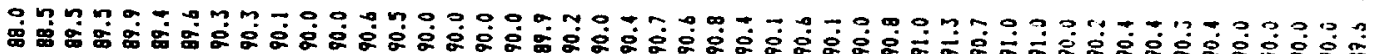

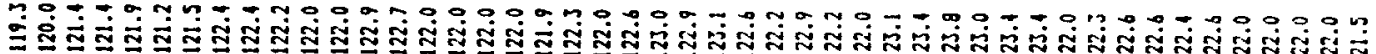

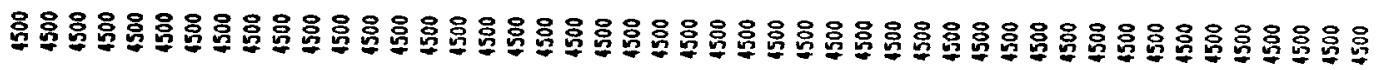

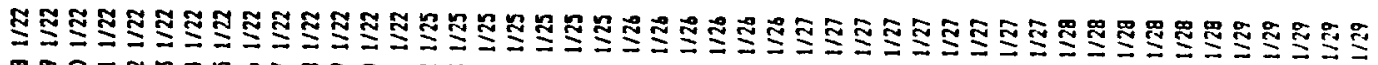

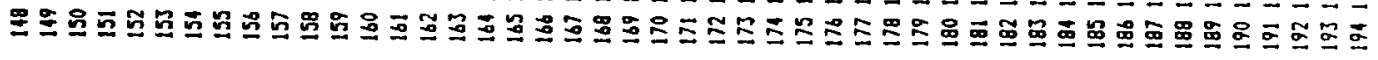

$\mathrm{G}-\mathrm{I}-8$ 


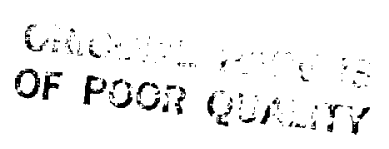

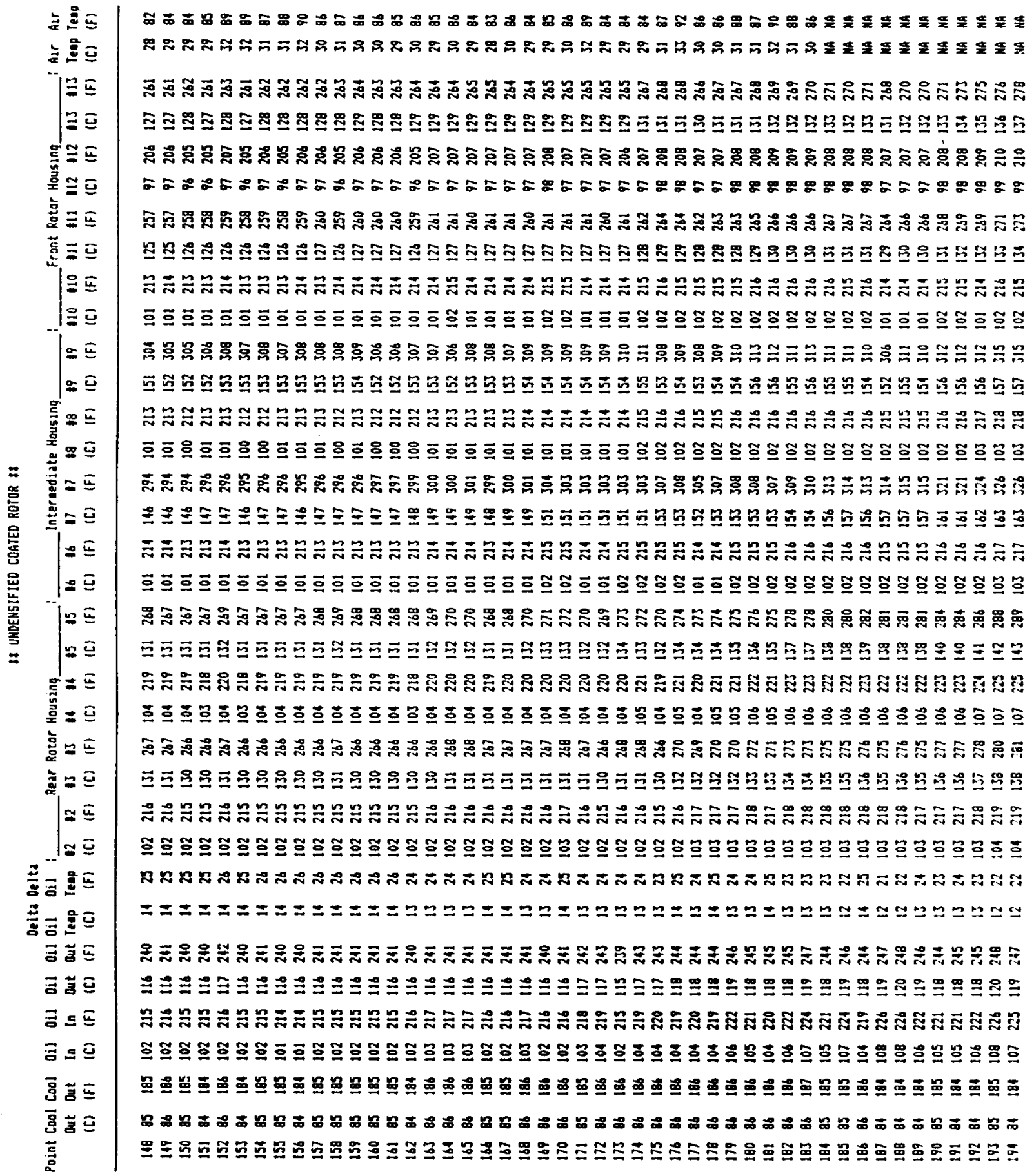

$$
\text { G-I-9 }
$$




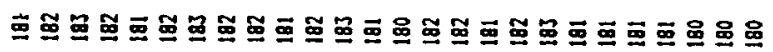

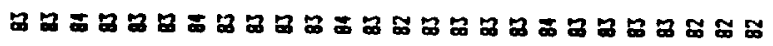

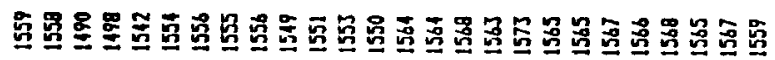

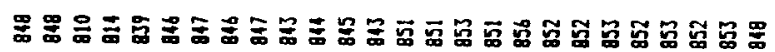

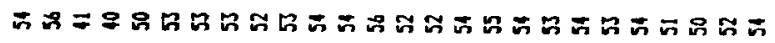
$\leq \mathrm{g}$ 可

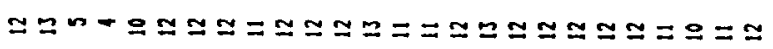

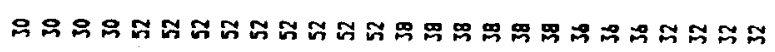

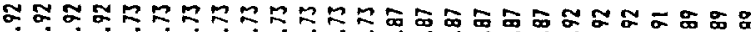

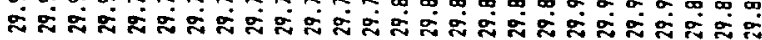

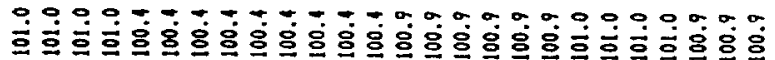

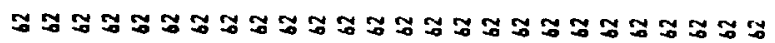

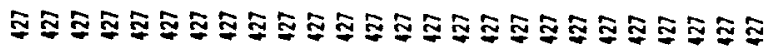

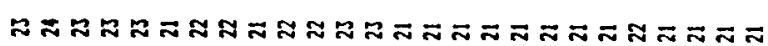

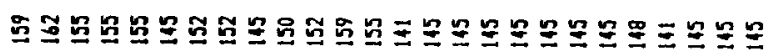
00000000000000000000000000

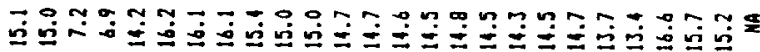

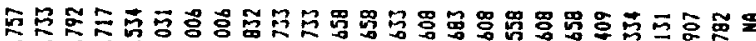

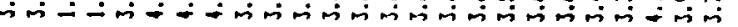

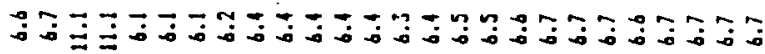

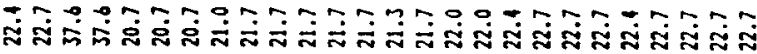

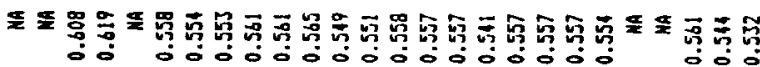

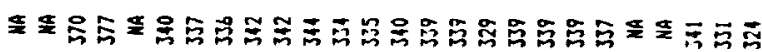

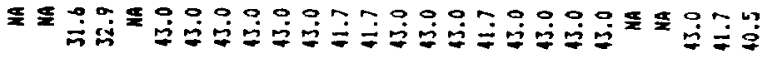

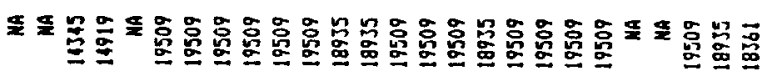

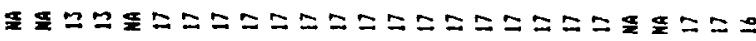

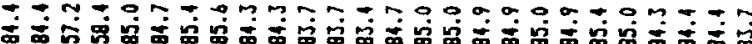

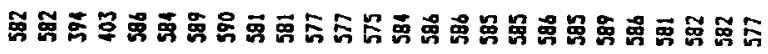

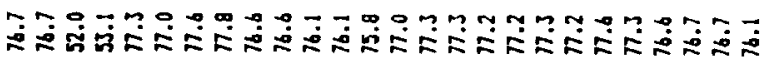

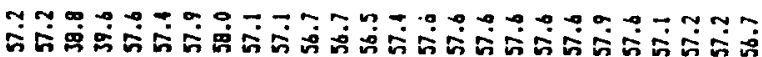

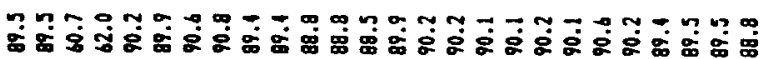

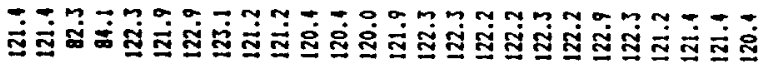

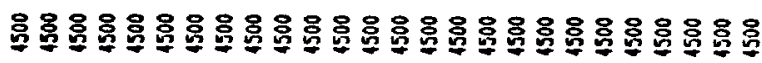

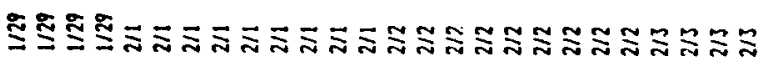

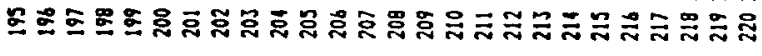


OF POL

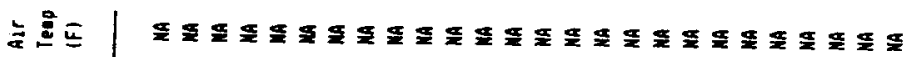

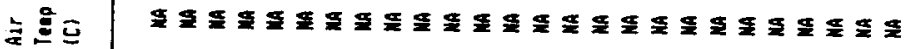

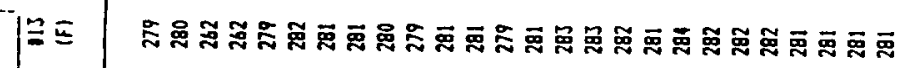

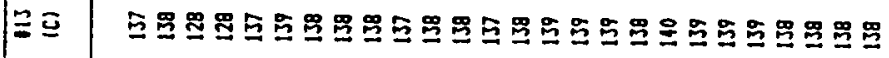

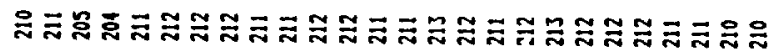

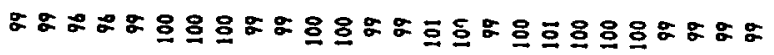

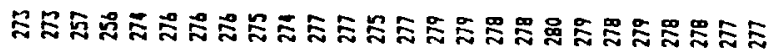

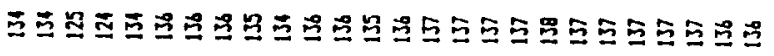

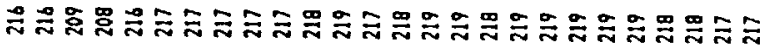

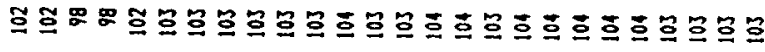

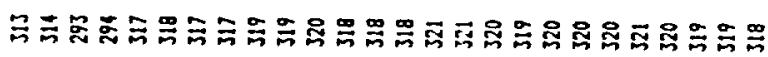

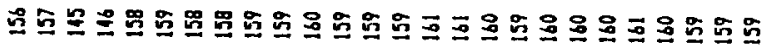

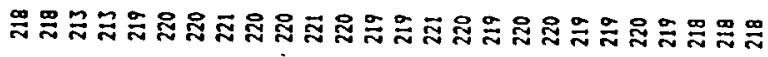

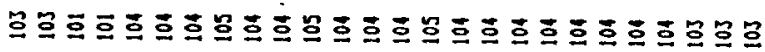

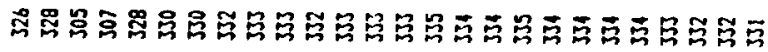

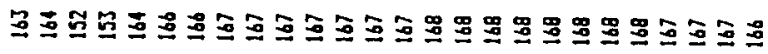

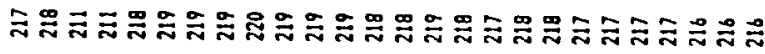

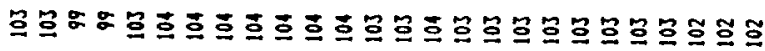

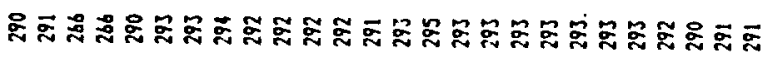

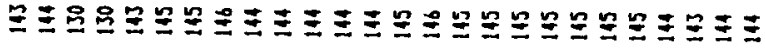
สลㅊ

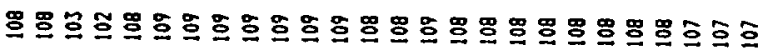

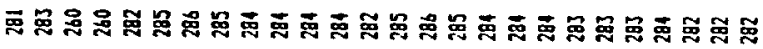

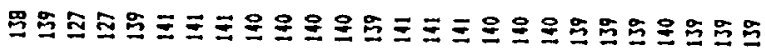
จะส

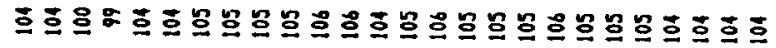
ดล์

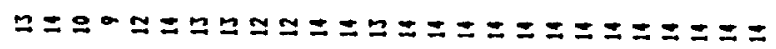

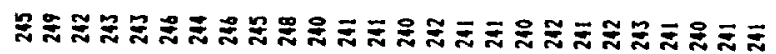

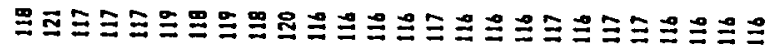

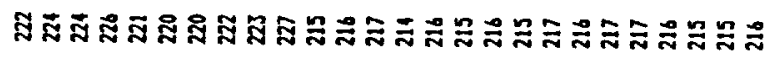

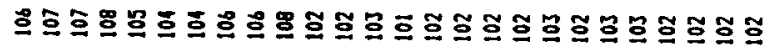

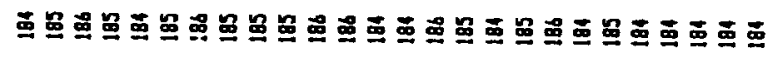

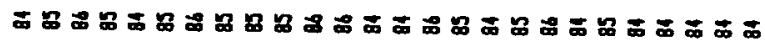

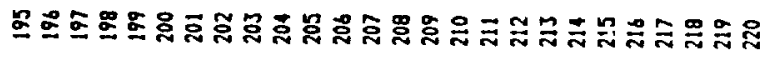





\section{APPENDIX G - II \\ DENSIFIED COATED}

ROTOR DATA

G-I I- 1 
DENSIFIED COATED ROTOR DATA

TABLE OF CONTENTS

Title

Page

Densified Coated Chart. . . . . . . . . . . . . . . . G-II-3

Densified Coated Chart. . . . . . . . . . . . . . . . G-II-4

Densified Coated Chart. . . . . . . . . . . . . . . . G-II-5

Densified Coated Rotor Data . . . . . . . . . . . . G-II-6

Densified Coated Rotor Data . . . . . . . . . . . . . G-II-7

Densified Coated Rotor Data. . . . . . . . . . . . G-II-8

Densified Coated Rotor Data . . . . . . . . . . . . G-II-9

Densified Coated Rotor Data . . . . . . . . . . . . . G-II-10

Densified Coated Rotor Data . . . . . . . . . . . . . G-II-11

Densified Coated Rotor Data . . . . . . . . . . . . . G-II-12

Densified Coated Rotor Data. . . . . . . . . . . . . G-II-13 


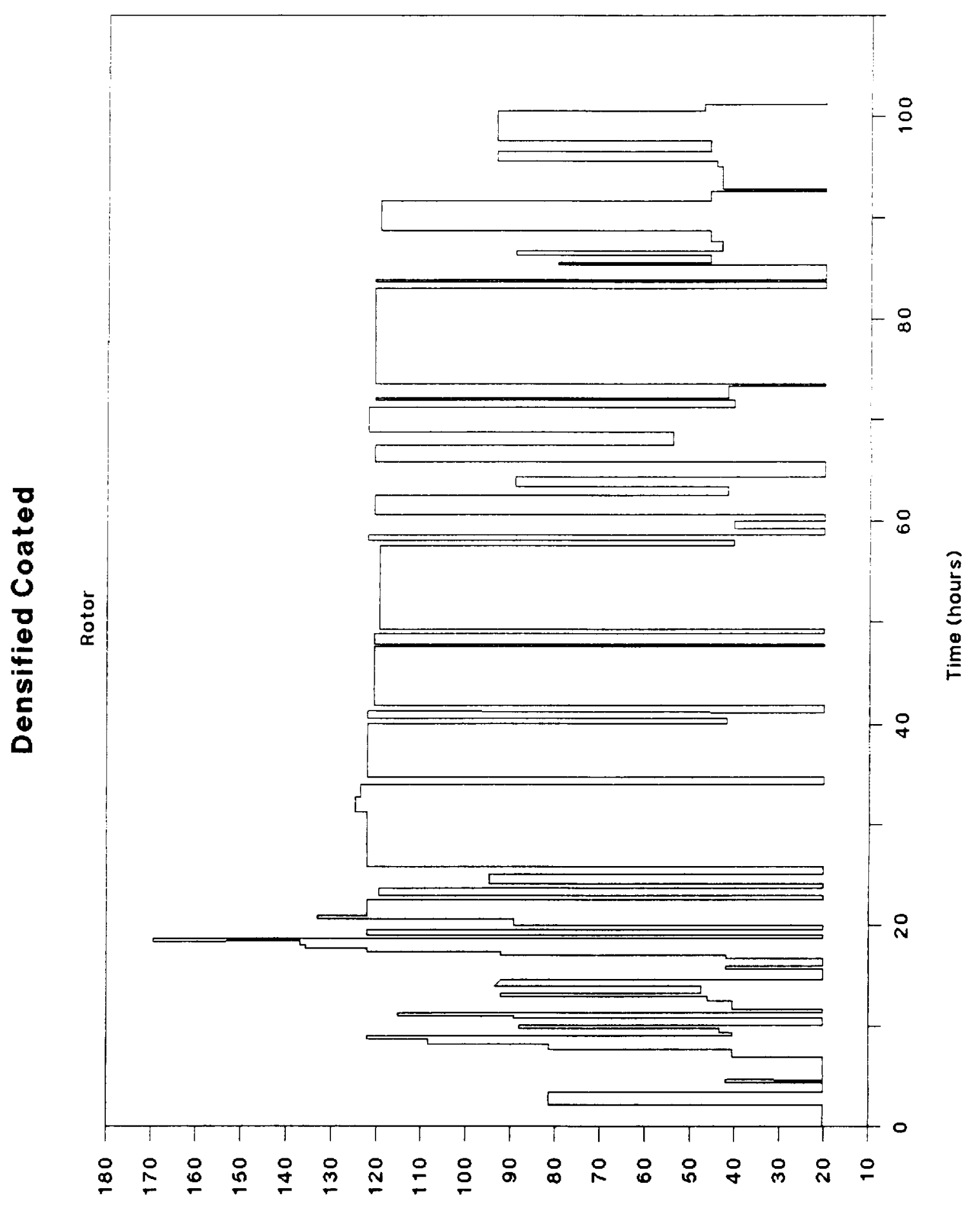

$\left(w_{* N}\right)$ enbjo 1

$$
\text { G-I I - } 3
$$




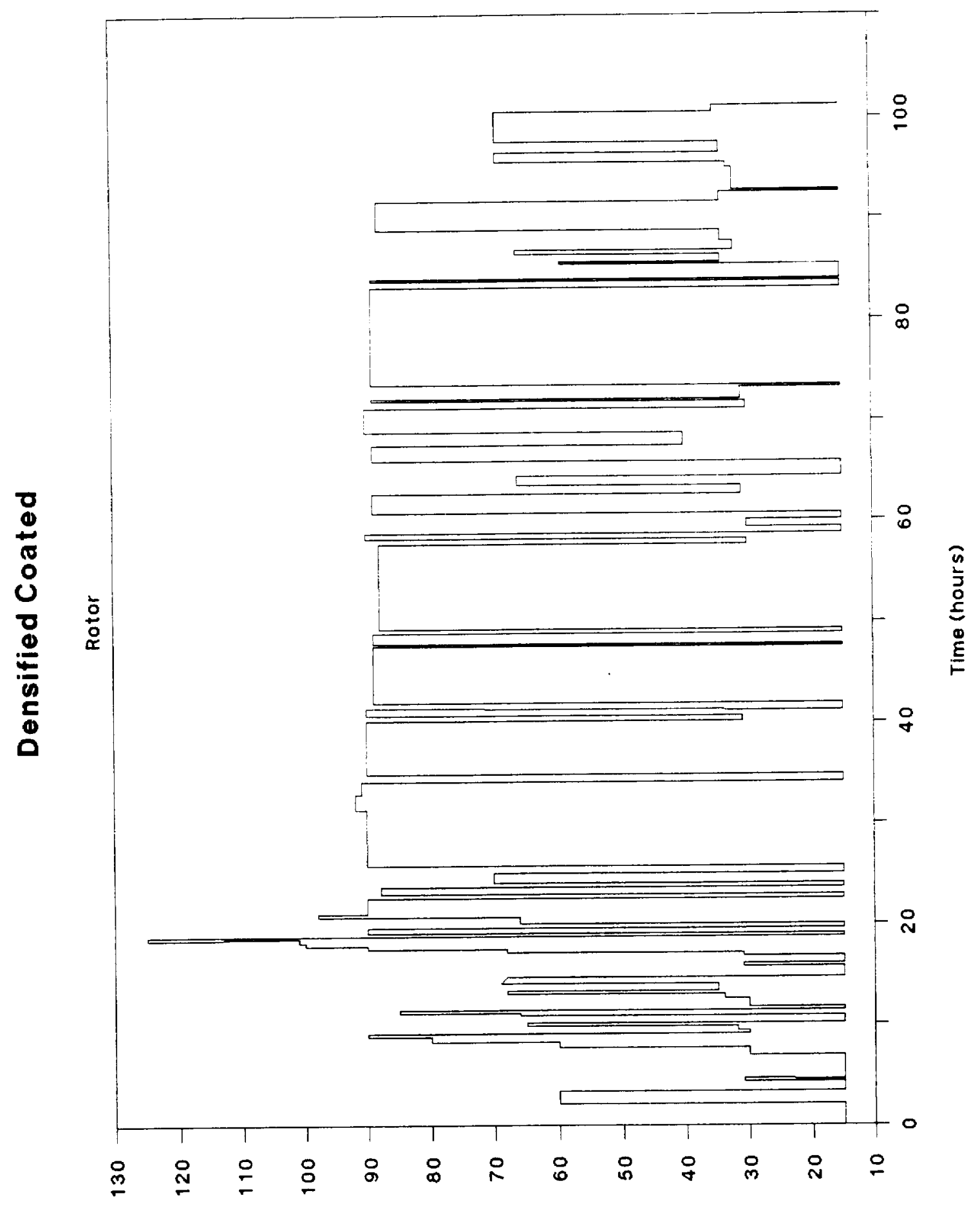

(zt*squ) enbsol

G-II-4 


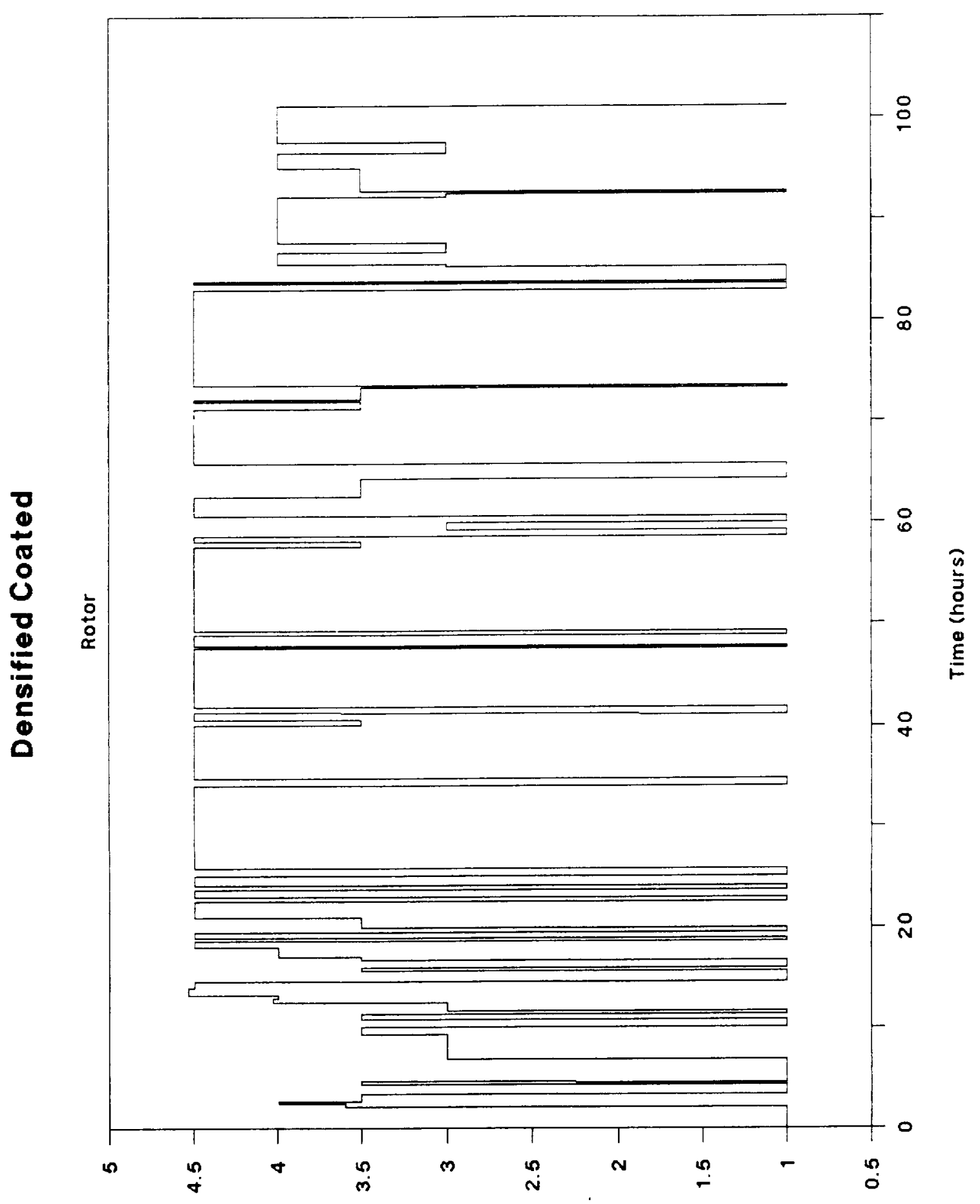

(spuesnoy 1 )

(udd) peods

G-I I - 5 
$\overrightarrow{\mathrm{g}}=$

$\vec{g} \leq \overline{\mathrm{S}}$

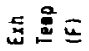

ธัฐ

$\leq \underline{\underline{a}}$

$\leq \Xi$

호

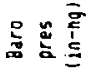

品高

咅䜌

吉言高

总芯营

总高

高学突

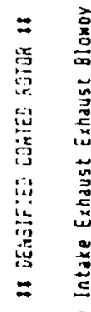

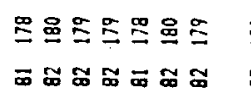

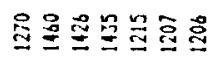

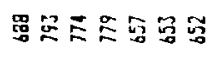

的구유

$T=0-T$

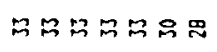

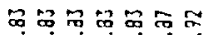

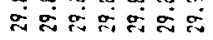



ะสำ

シミ索声

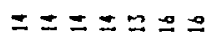

ㅊㅎㅊ으응

웅융영영영

웅영영영영

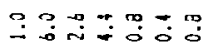

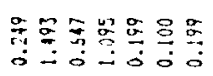

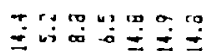

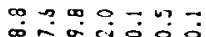

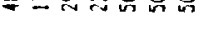

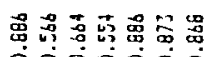

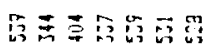

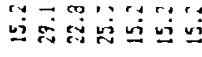

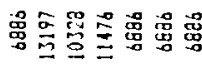

0 주으.

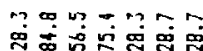

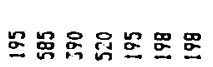

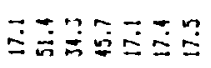

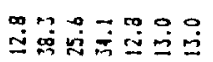

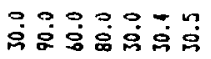

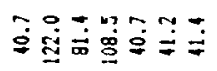

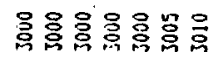

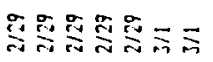

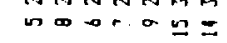

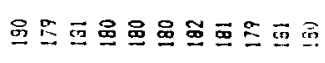

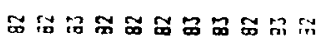

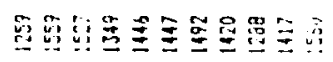

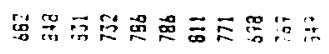

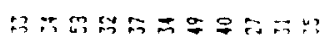

$-\cdots+\cdots-a-n-1$

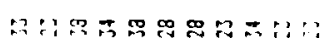

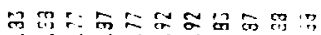
न

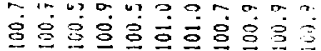

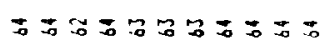

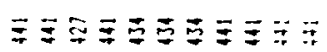

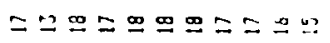

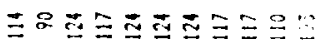

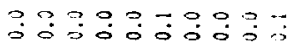

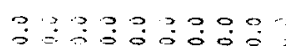

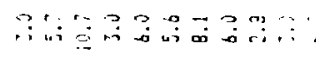

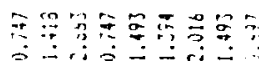

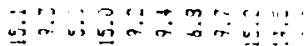

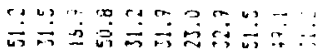

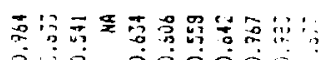

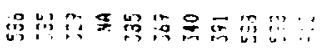

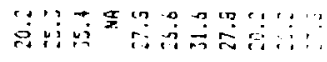

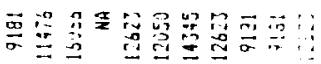

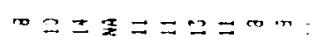

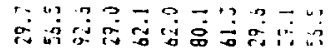

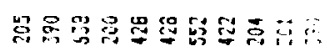

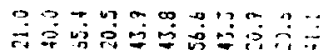

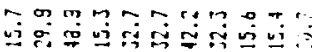

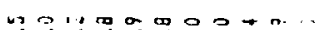

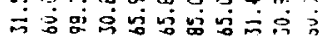

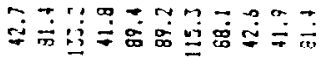

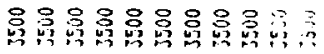

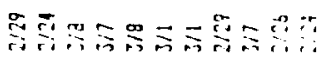
의 0
므음요

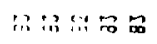

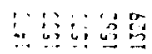

湿落点品

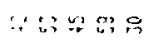

a. $\because \cdots$

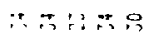

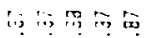

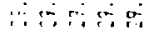

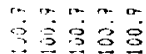

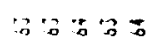

落总三

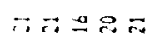

里哭是里

$\therefore \therefore \div 3$

$\therefore \therefore \therefore ?$

$\therefore+2+2$

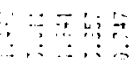

'虽

an

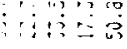

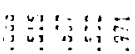

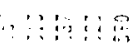

ל

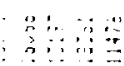
$\ldots, \ldots=0$

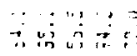
(9) a 萡

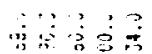

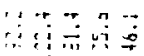

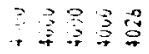
$\therefore \therefore \vec{\square}$ $\therefore:: \cdots::=$

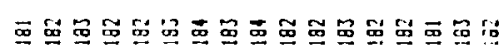

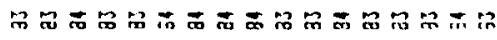

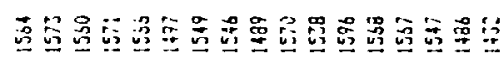

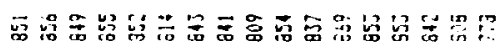

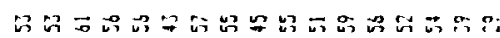

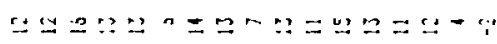

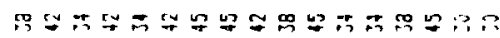

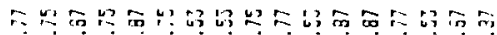
कम

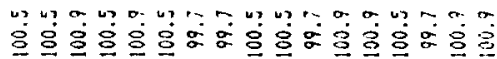

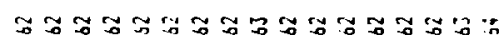

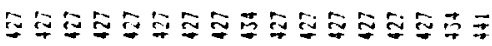

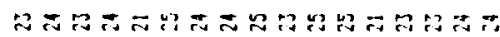

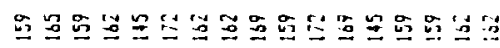

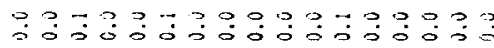

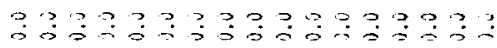

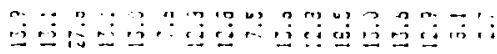

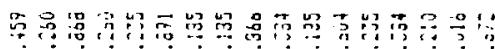
Q

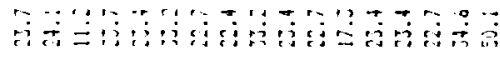

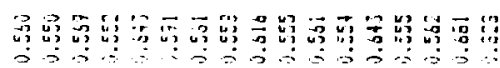

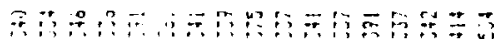

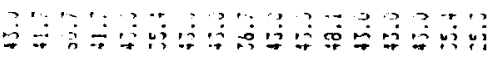

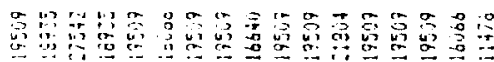

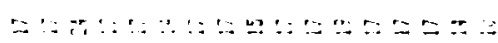

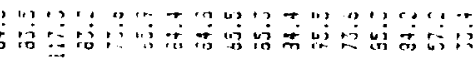

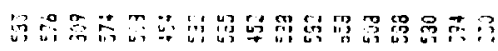

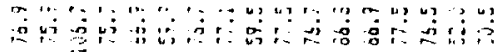

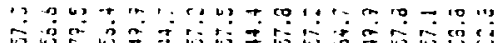

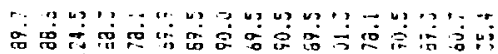

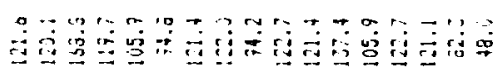

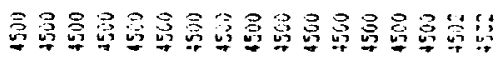

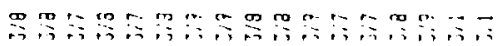

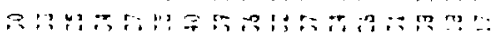

$$
\text { G-II- } 6
$$




\section{ORIGINAL PAGE IS \\ OF POOR QUALITY}

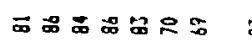

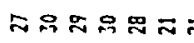

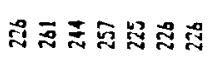
ㅇㅗㅀㅗㅀ요요

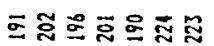
思よる思する

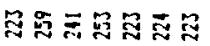

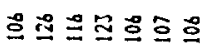

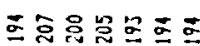

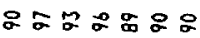

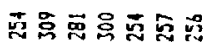

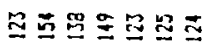
오옳 $\approx 250252$

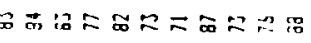

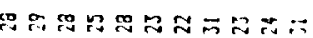

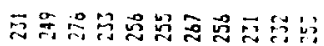

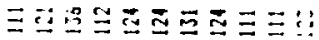

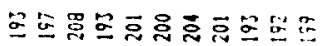
๙

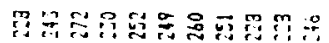

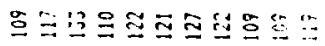

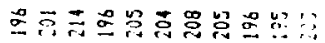
る゙

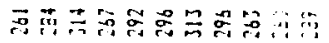

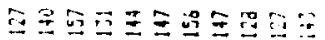

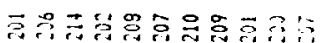
드
\end{abstract}

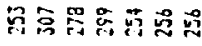

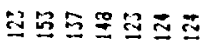

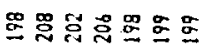

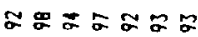

สำ

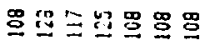

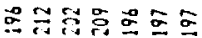

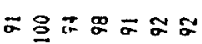

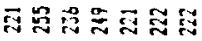

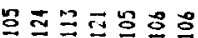

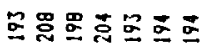

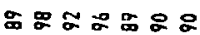
ロニスエニニ ก⿻上丨า

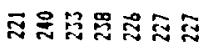

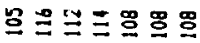

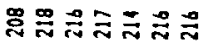

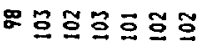

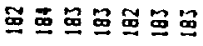

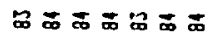
nos-on

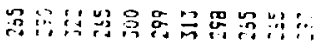

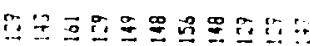

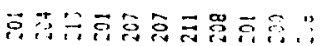

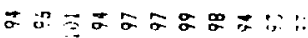

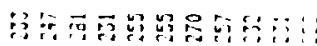

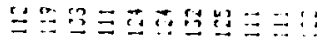

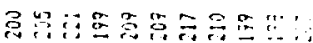

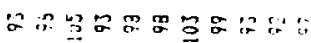

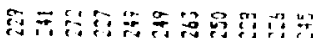

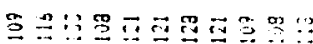

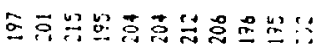

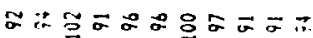

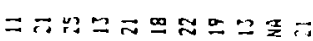

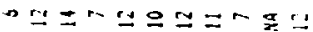

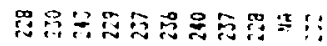

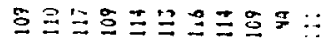

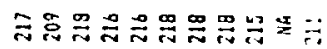

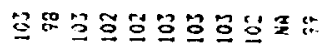

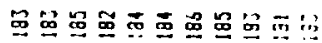

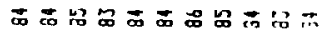

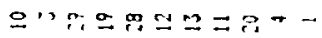

$\therefore 3 \therefore 8=$

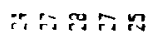

苛是落焦是

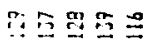

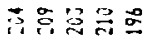

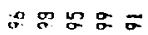

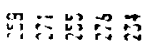

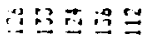

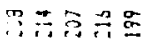

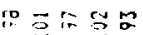

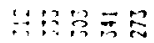

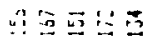

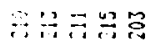

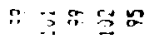

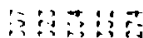

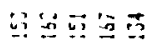

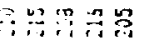

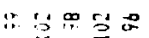

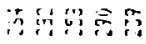
ำ

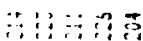

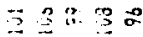

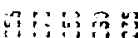

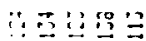

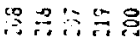

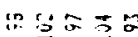
14:

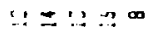

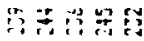

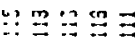

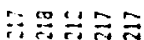

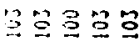

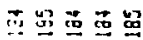

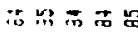
ia $14 \cdots: 3=9$

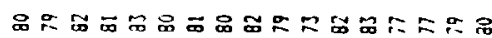

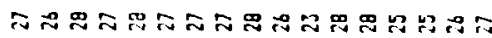

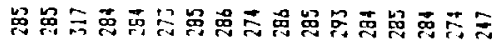

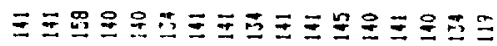

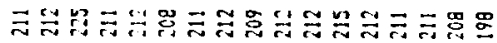

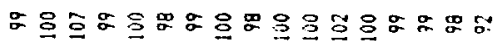

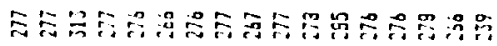

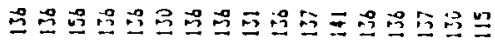

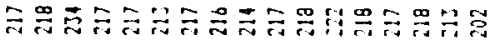

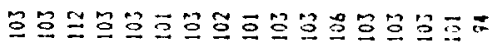

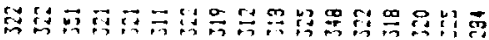

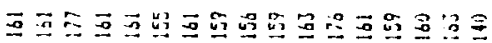

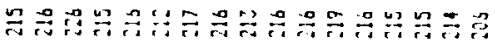

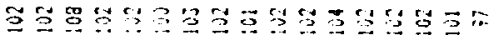

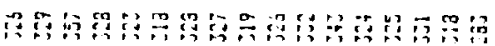

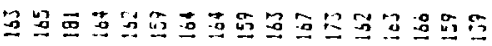

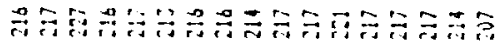

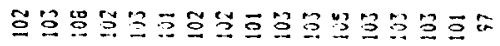

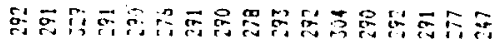

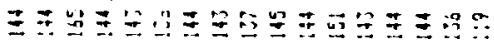

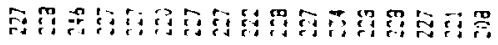

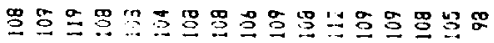

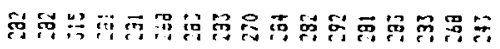

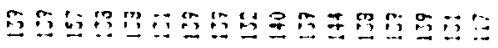

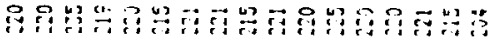

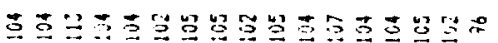

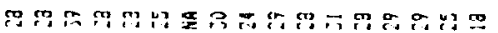

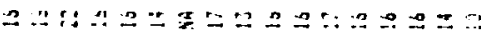

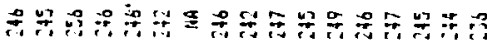

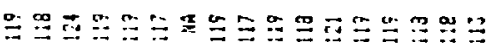

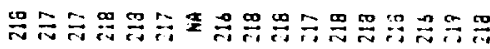

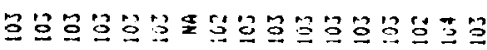

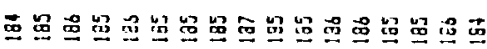

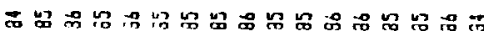

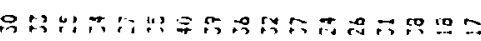


总 5 $\overline{8} \leq \bar{\Xi}$ 总言

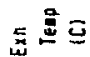
$\leq \underline{\underline{a}}$

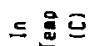
章 号高要

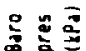
咅产 㤩突 竞岕畐 亨菨 言高高

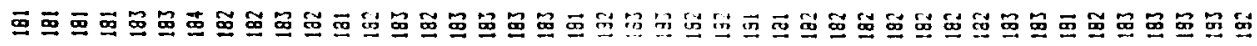

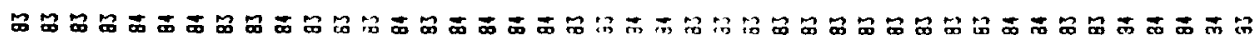

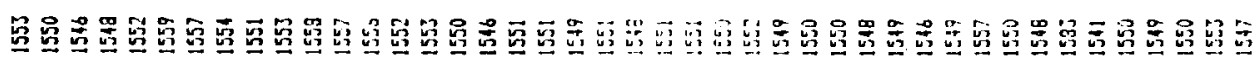

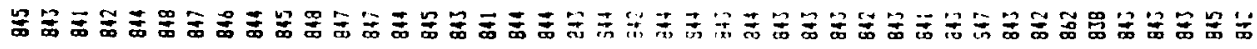

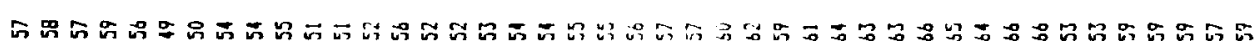

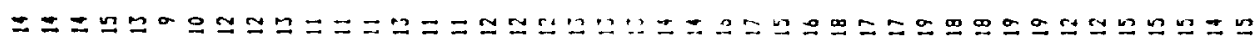

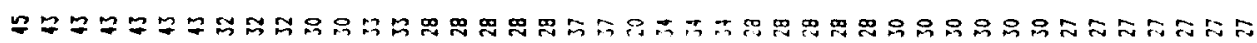

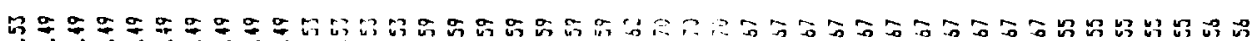

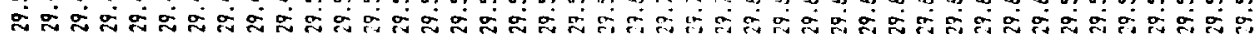

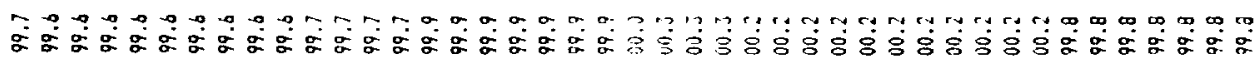

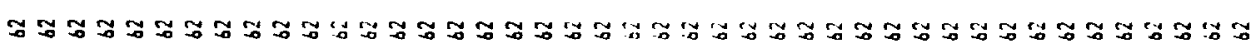

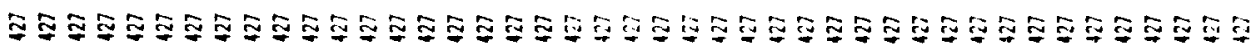

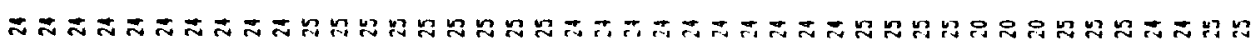

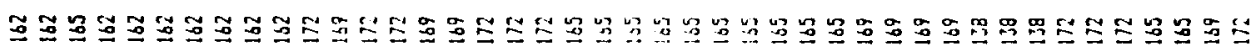

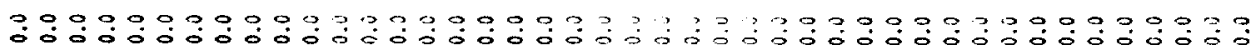

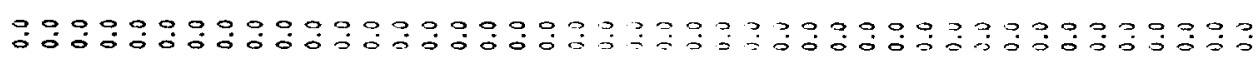

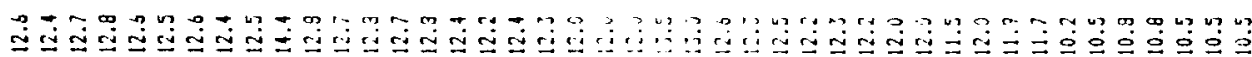

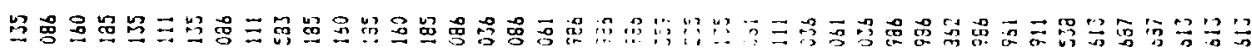

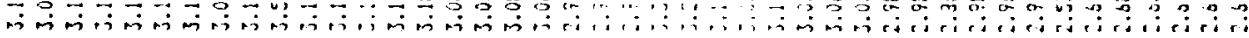

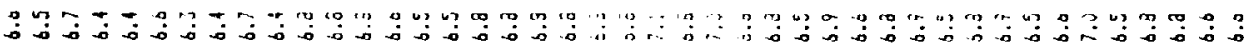

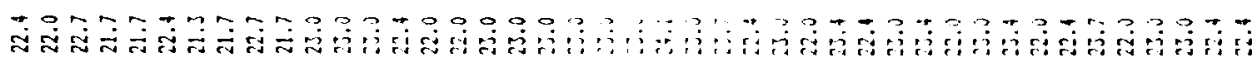

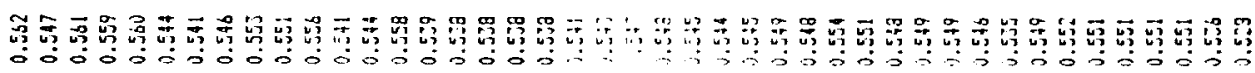

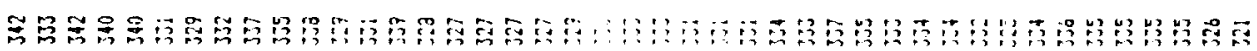

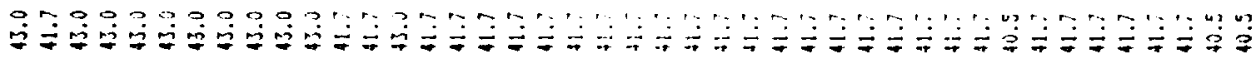

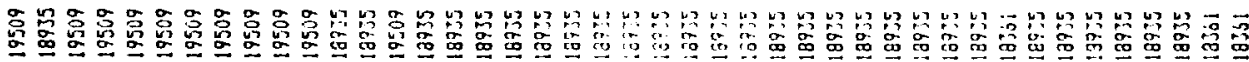

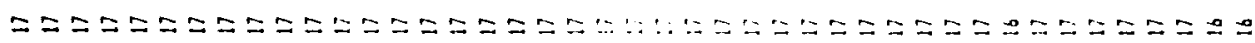

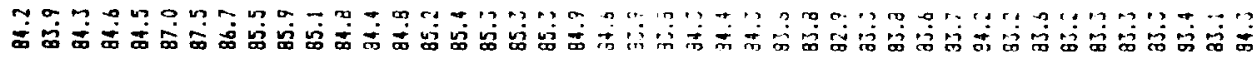

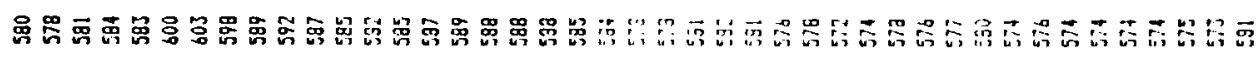

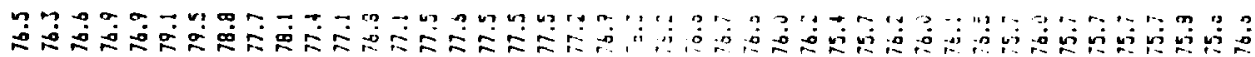

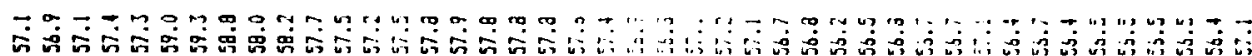

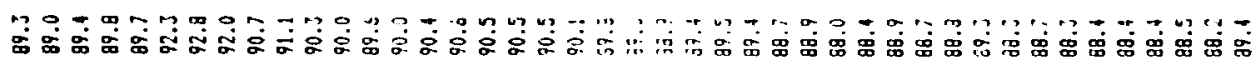

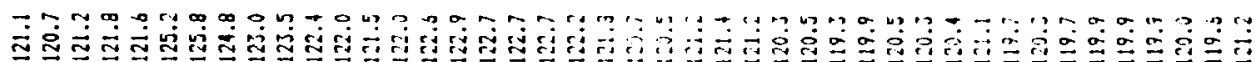

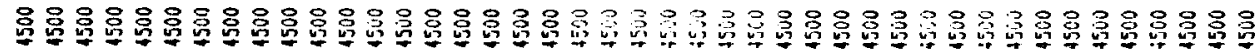

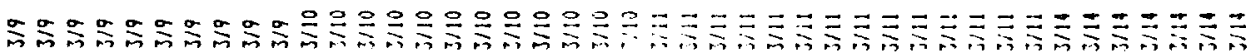

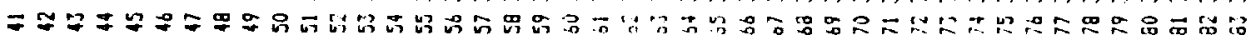

$$
\text { G-II-8 }
$$




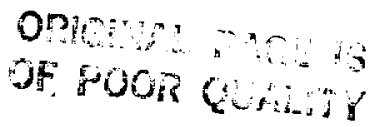

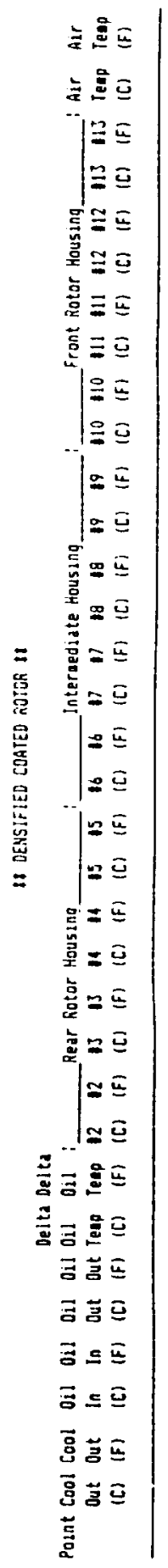

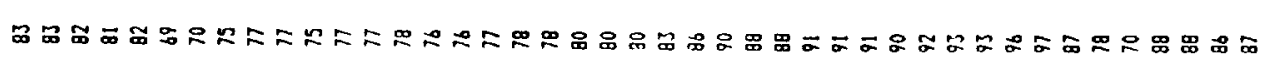

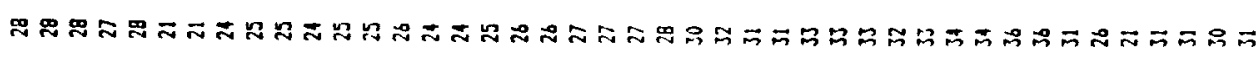

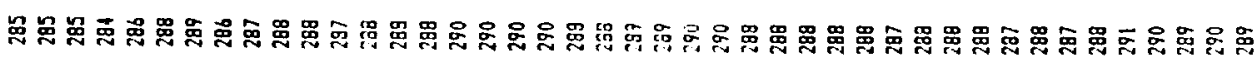

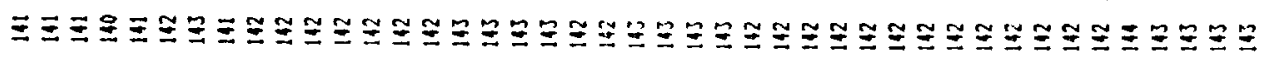

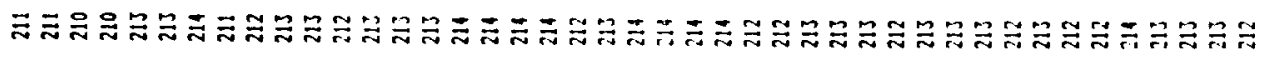

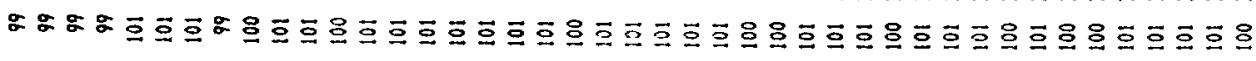
స

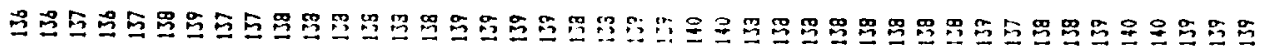

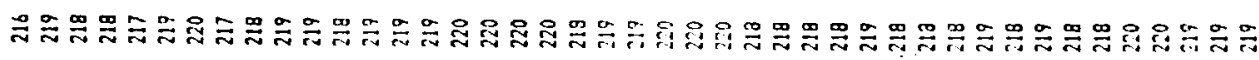

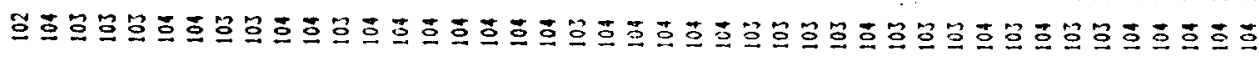

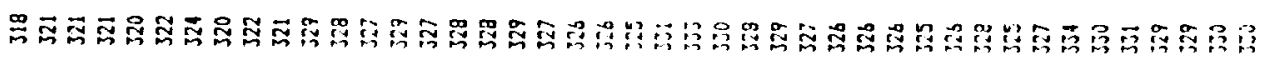

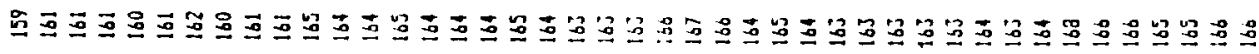

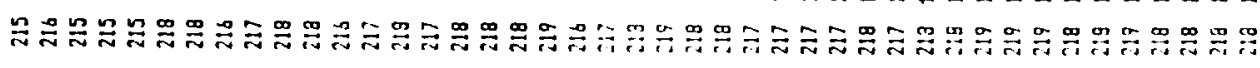

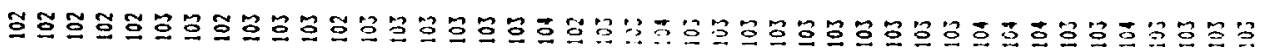

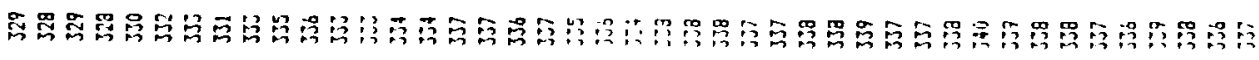

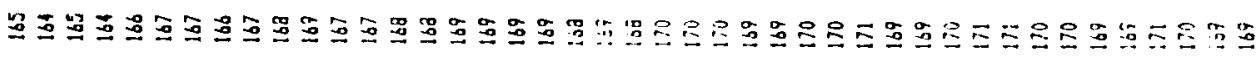

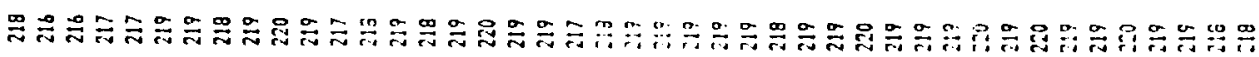

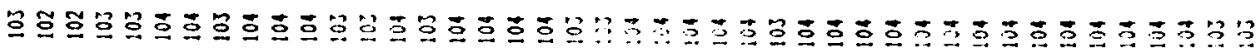

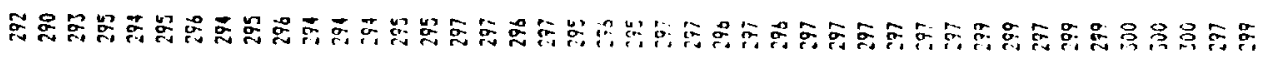

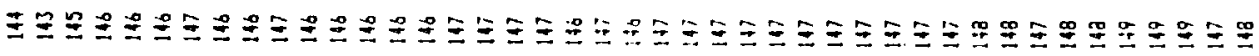

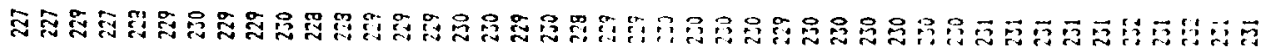

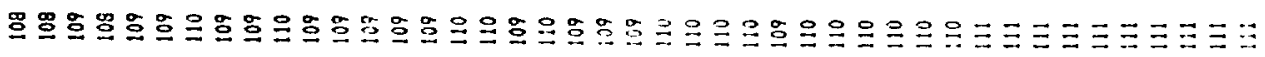

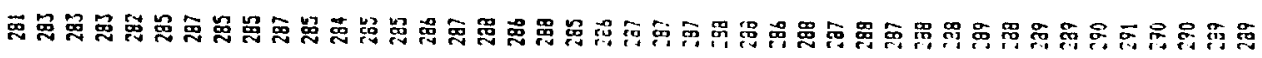

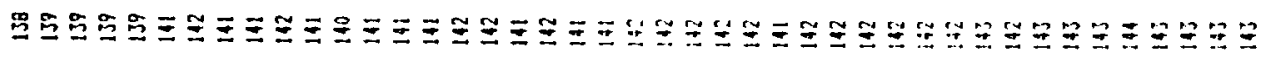
สิ

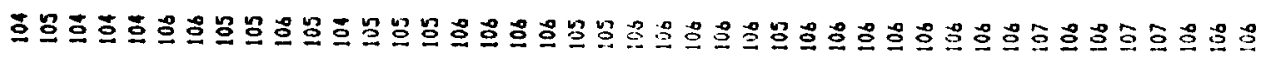

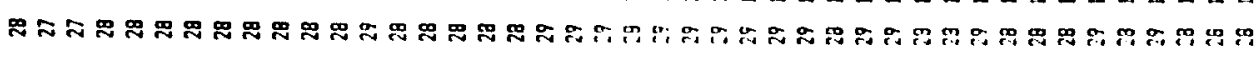

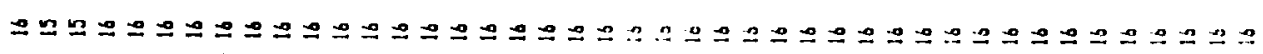

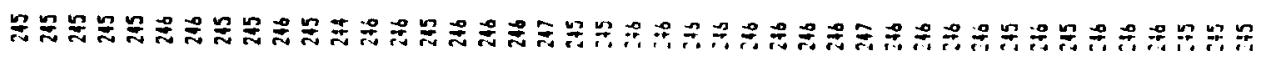

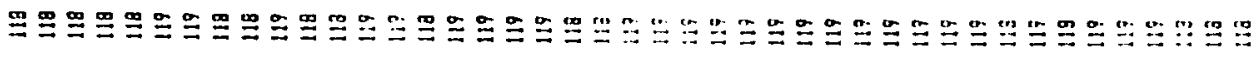

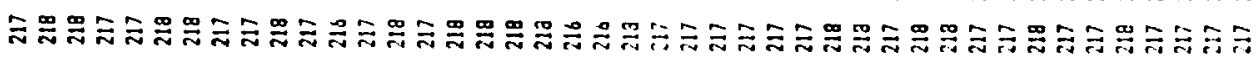

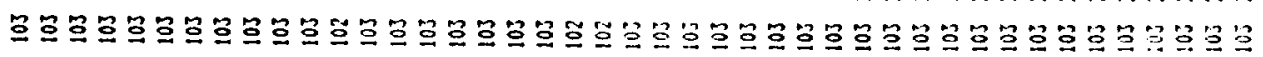

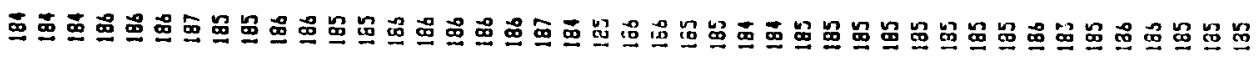

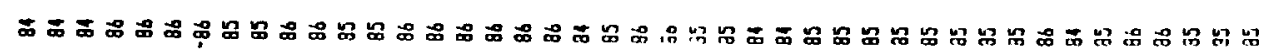

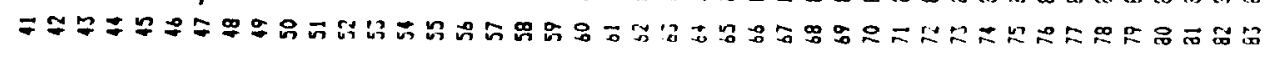


$\bar{g} \leq 5$

总 $\simeq$ 프

苦亨

急密

$\leq \underline{a}$

$\leq \mathrm{a}$

宩

妾高紊

号高

宁高蓠

宫高

宫参焉

总芲紊

홍

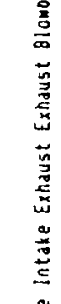

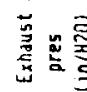

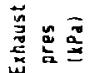

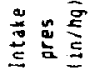

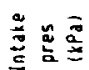

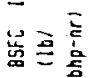$$
\text { 魚高 }
$$

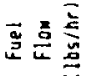

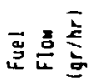

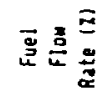

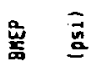$$
\text { 喜 }
$$$$
\text { 高 高 }
$$$$
\text { 盗 }
$$$$
\text { 亲 }
$$$$
\text { 产 }
$$

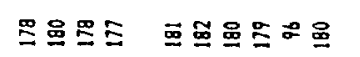

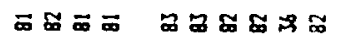

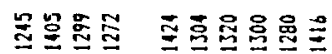

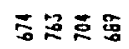
요요 Tกn은ำ 우용요요 용 명영영 $8=37$

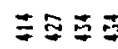
ะㅗำ 므응 웅웅융영 옹영영영영 영영영

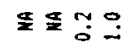
영영영영

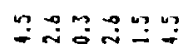

옹옹용 웅 영영

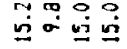

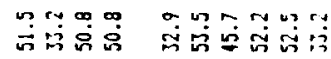

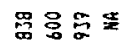
:

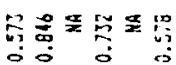

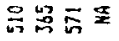

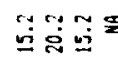
惫西惫 $\rightarrow \infty x$

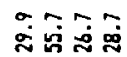
蛋兽五

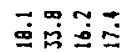

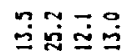

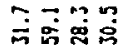
宫总富

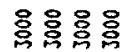

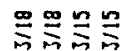
요요

ำ

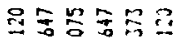

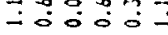

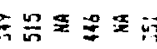

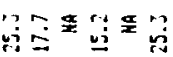

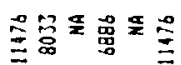

으-도이응

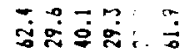

옹호오욣

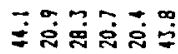

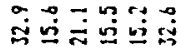

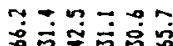

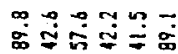

总量总量量量

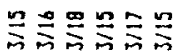

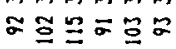

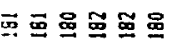

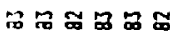

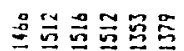

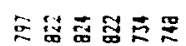

ำ影的品

- $\because \geq \because ロ r$

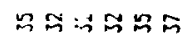

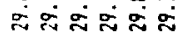

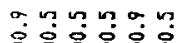

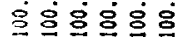

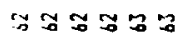

옳ํㅛ

요요요 주

可品思思三

뭉명영영영웅

영영융웅영웅

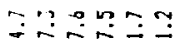

导范要品骂

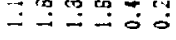

نق

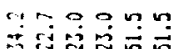

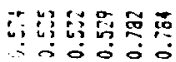

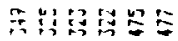

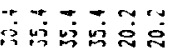

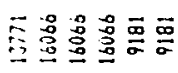

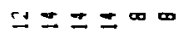

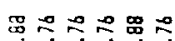

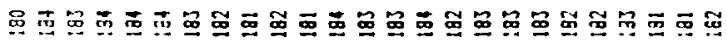

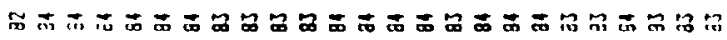

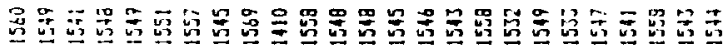

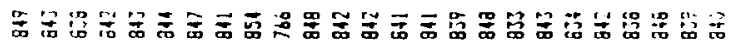

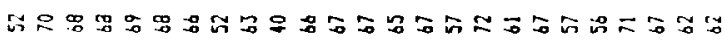

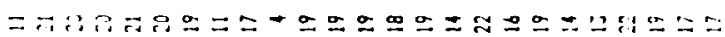

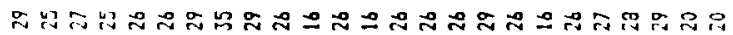

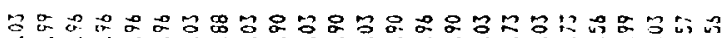

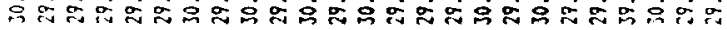

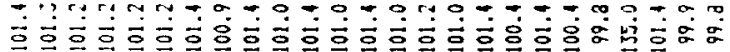

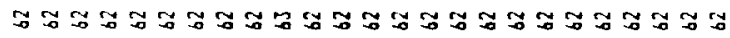

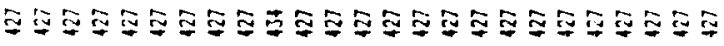

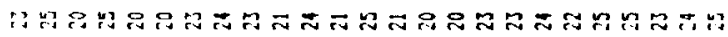

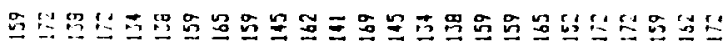

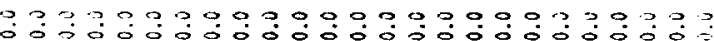

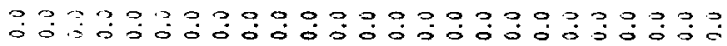

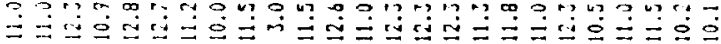

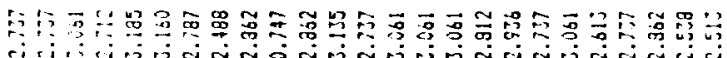

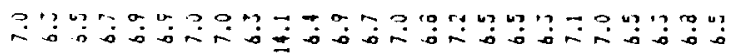

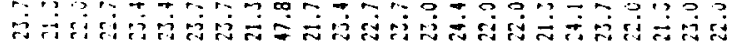

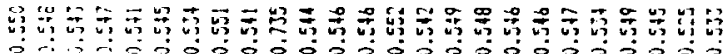

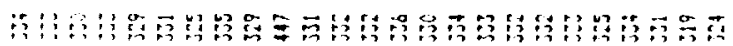

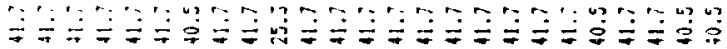

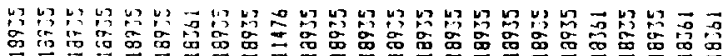

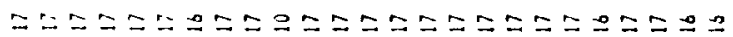

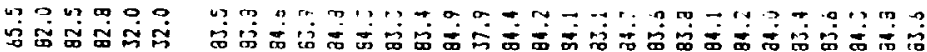

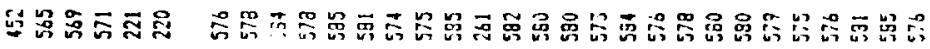

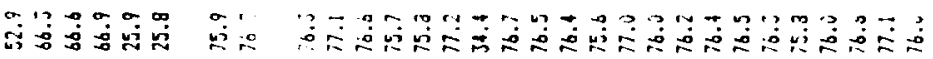
" -

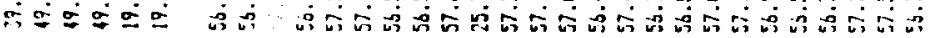

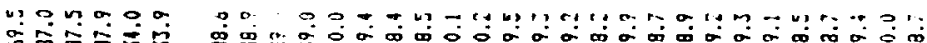

Ұ웅

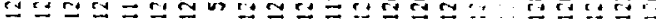

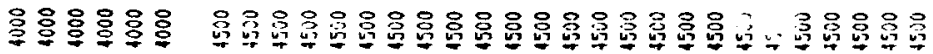

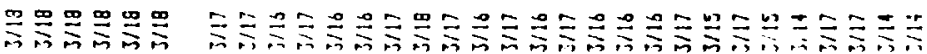

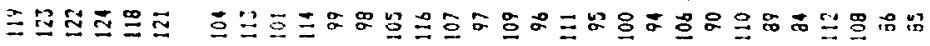

$G-I I-10$ 


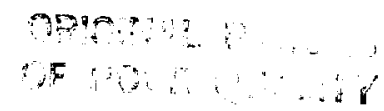

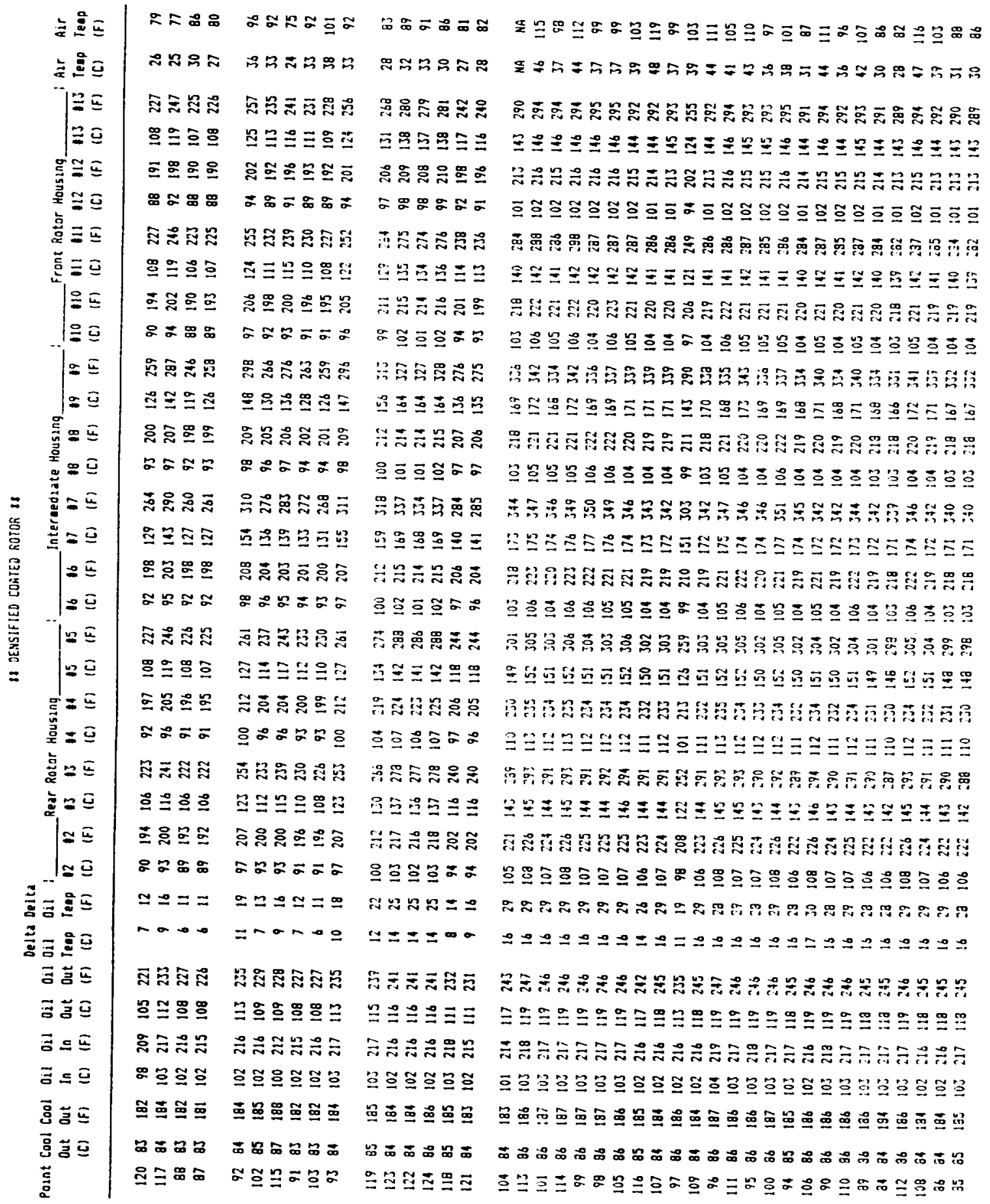




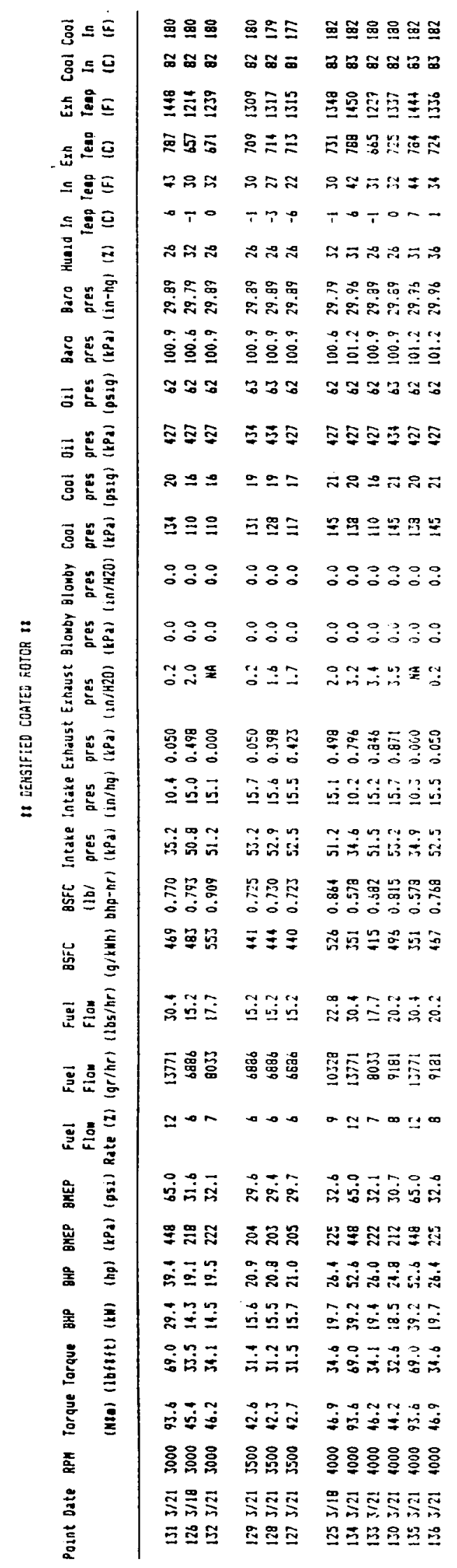




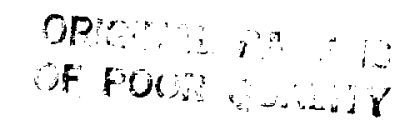

\begin{tabular}{|c|c|c|c|}
\hline 言巨 & $2 \overline{00}$ & $\approx \infty=$ & $\overline{\mathbf{\omega}} \sigma$ \\
\hline $\bar{a}$ & $\pi \approx D$ & $M \approx \approx$ & in \\
\hline & $\Phi \equiv$ & 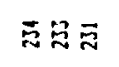 & $\approx \Sigma \bar{\Sigma}$ \\
\hline & $\cong \Xi \Xi$ & $\Xi \cong \Xi$ & $\Xi \Xi$ \\
\hline$=$ & $\begin{array}{l}\Xi \Xi \Xi \\
2 \Xi \Xi\end{array}$ & $\begin{array}{l}\Xi \Xi \Xi \\
\Xi \Xi \Phi\end{array}$ & $\begin{array}{l}\Phi \Xi \\
\Xi \approx\end{array}$ \\
\hline & 品 & $\tilde{\Xi} \bar{\Xi}$ & $g$ \\
\hline & 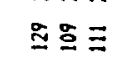 & $\Xi \Xi \cong$ & $\stackrel{ }{\Xi} \Xi \Xi \bar{\Xi}$ \\
\hline & $\stackrel{人}{2} \approx$ & $\Xi \Xi$ & $\bar{\Omega} \approx \Xi \Xi \approx \bar{\Sigma}$ \\
\hline & $\approx \approx \bar{~}$ & 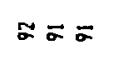 & 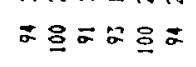 \\
\hline$=$ & $\cong \approx$ & $\mathfrak{d}$ & 오요요요 \\
\hline & 오요모 & $\overline{\Xi \Xi} \Xi$ & $\because$ \\
\hline 善 & ีㅗำ & 帘只 & $\equiv \bar{s}$ \\
\hline & 吕まま & まょま & $\approx \equiv$ \\
\hline $\overrightarrow{\vec{z}}=$ & $\bar{a} \bar{a}$ & EE & 思胥: \\
\hline 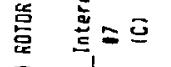 & 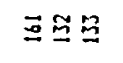 & $\cong \cong$ & $\Xi \Xi:$ \\
\hline & స̃ & ฐี వ요 & 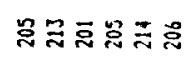 \\
\hline 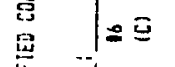 & 920 & ままま & ஃらるっする \\
\hline$=$ & $\Xi \tilde{\approx} \overline{\tilde{n}}$ & ఏ心 & 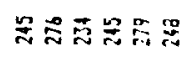 \\
\hline & $\cong \Xi \Xi$ & 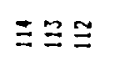 & 을뫀오옹 \\
\hline 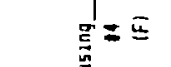 & ప ఏి & 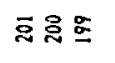 & కిశ్జ \\
\hline 离 $=$ & \pm 20 & $=22$ & 5 \\
\hline$\frac{5}{2}=5$ & $\stackrel{\Phi}{\mathbb{N}}$ & 로용 & $\Xi 2$ \\
\hline & 명용 & $\cong \equiv 0$ & 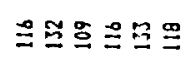 \\
\hline$\approx$ & 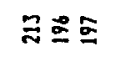 & $\Xi \Xi \Xi$ & こううるこうう \\
\hline$\approx 5$ & $\Xi \bar{a}$ & $\approx \approx \approx$ & まミょるす。 \\
\hline 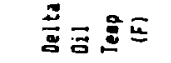 & $\approx==$ & $\simeq=2$ & $a \vec{\alpha}=2 \mathrm{a}=$ \\
\hline 妾 & & $n$ & $\alpha \simeq-\infty \geq \sigma$ \\
\hline & $\Sigma$ స & $\mathbb{\approx}: \approx \approx \pi$ & 可里里总总司 \\
\hline $\bar{z} \mathbf{3}$ & 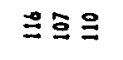 & 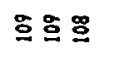 & $\Xi \Xi \Xi \Xi \Xi \Xi$ \\
\hline$\vec{\sigma} s$ & $\stackrel{\approx}{\approx} \Xi$ & $\stackrel{2}{\sim} \stackrel{2}{\sim}$ & $\cong \cong \cong \approx \cong$ \\
\hline$\vec{\Xi} s$ & $\underline{\Xi \Xi}$ & $\Xi \Xi \Xi$ & 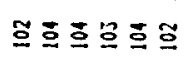 \\
\hline & $\underline{\underline{9}} \underline{\underline{9}} \underline{\underline{0}}$ & $\underline{\Xi} \mathbf{\Xi} \mathbf{\Xi}$ & 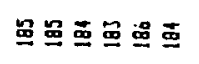 \\
\hline 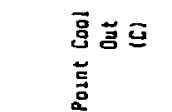 & $\begin{array}{l}\Xi \varpi \Phi \\
\Xi \Xi \Xi\end{array}$ & 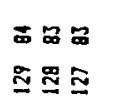 & 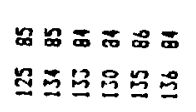 \\
\hline
\end{tabular}

G-II-13 



\section{APPENDIX H \\ COATED ALUMINUM \\ ROTOR HOUSING DATA}

$\mathrm{H}-1$ 


\section{COATED ALUMINUM ROTOR HOUSING DATA}

TABLE OF CONTENTS

Title

Page

Coated Aluminum Chart . . . . . . . . . . . . . . . . . . . .

Coated Aluminum Chart . . . . . . . . . . . . . . . . . . . . • • H-4

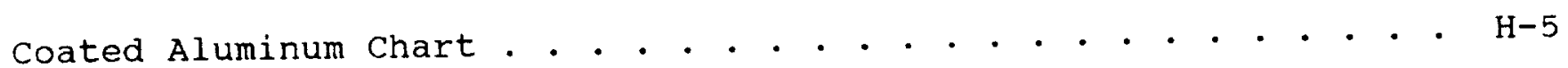

Coated Aluminum Rotor Housing Data. . . . . . . . . . . . . . . . H-6

Coated Aluminum Rotor Housing Data. . . . . . . . . . . . . . • $. ~ H-7$ 


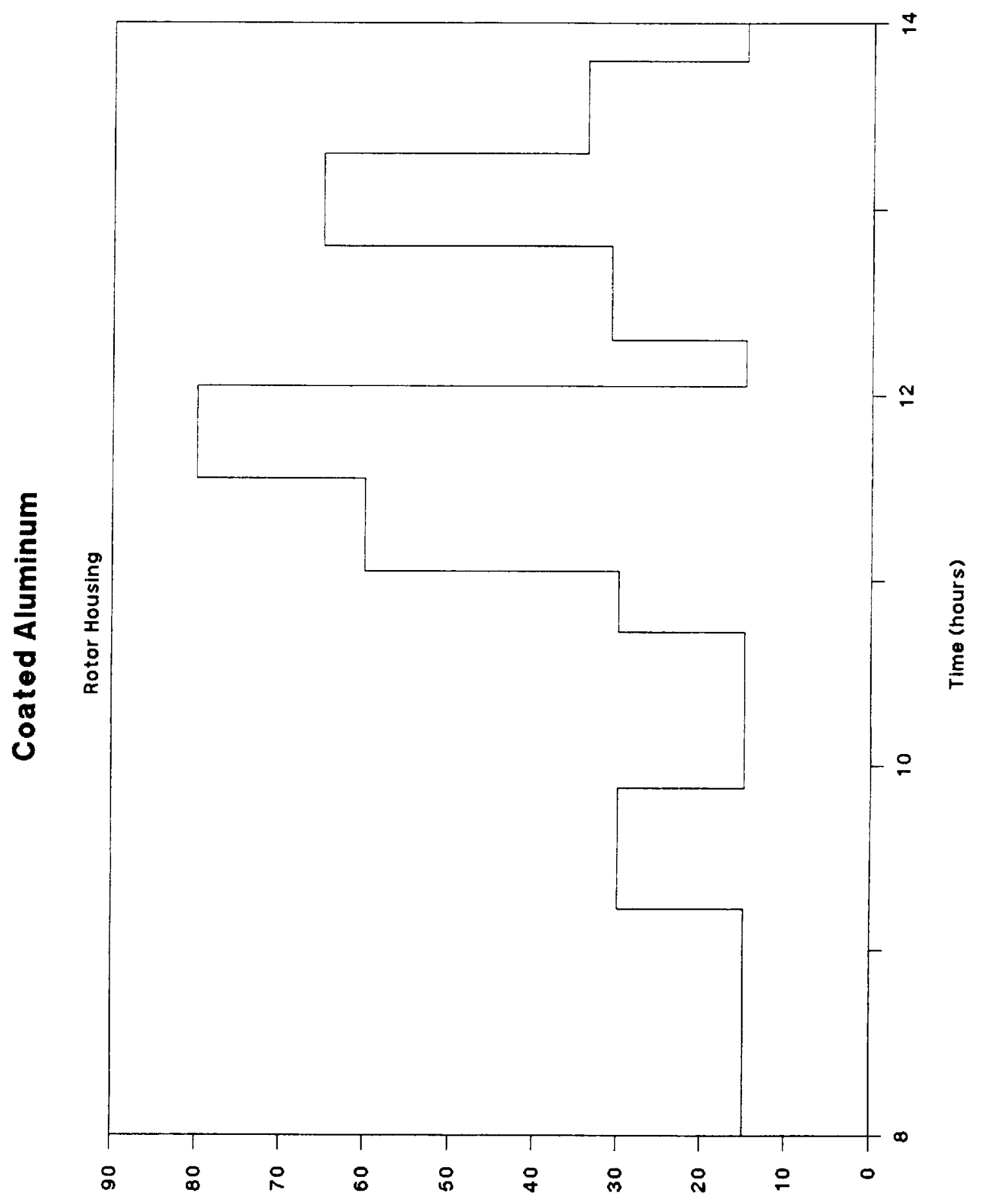

(tf*sql) enbsol

$$
\mathrm{H}-3
$$




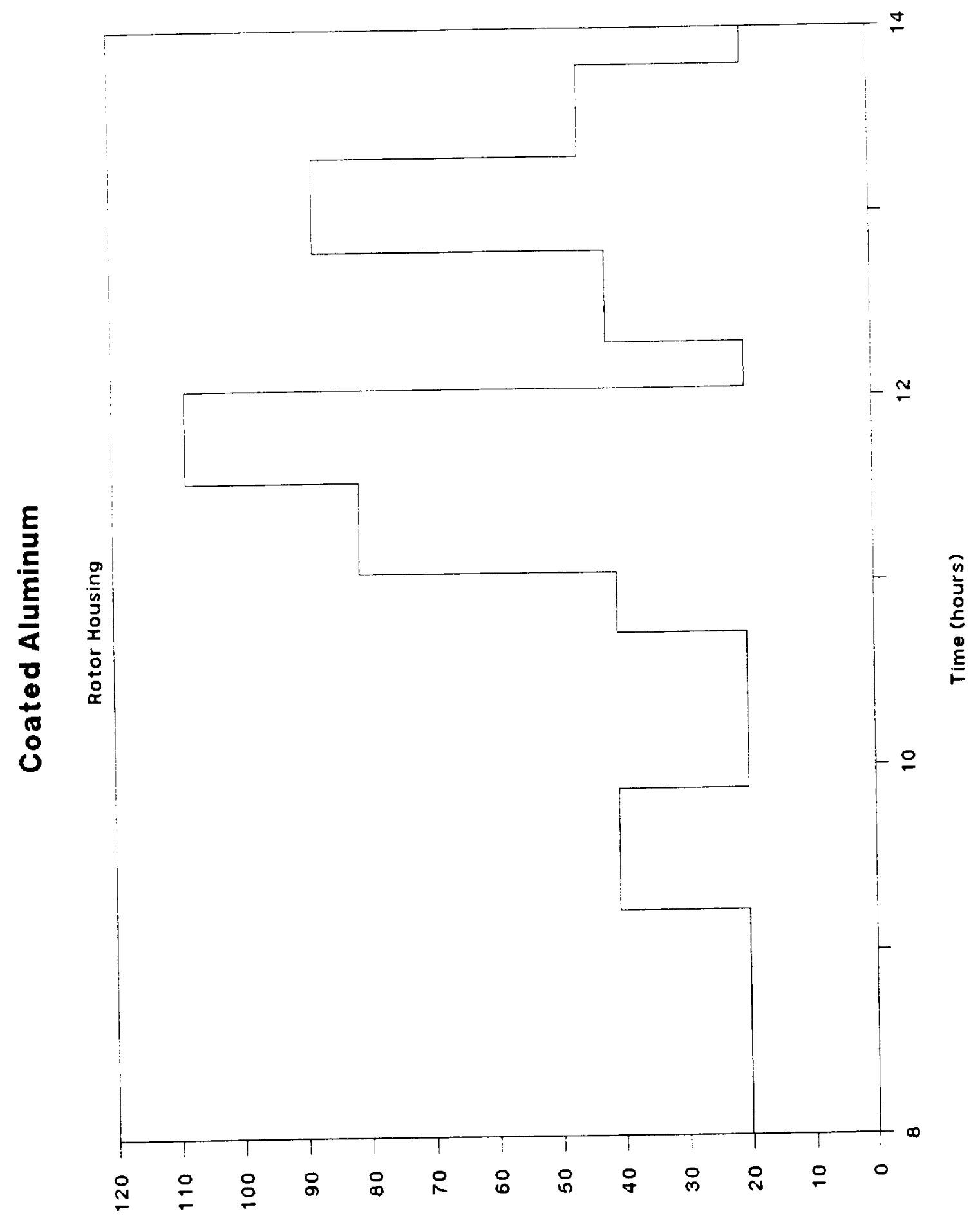

$\left(u_{* N}\right)$ enb $\lrcorner 01$

$\mathrm{H}-4$ 


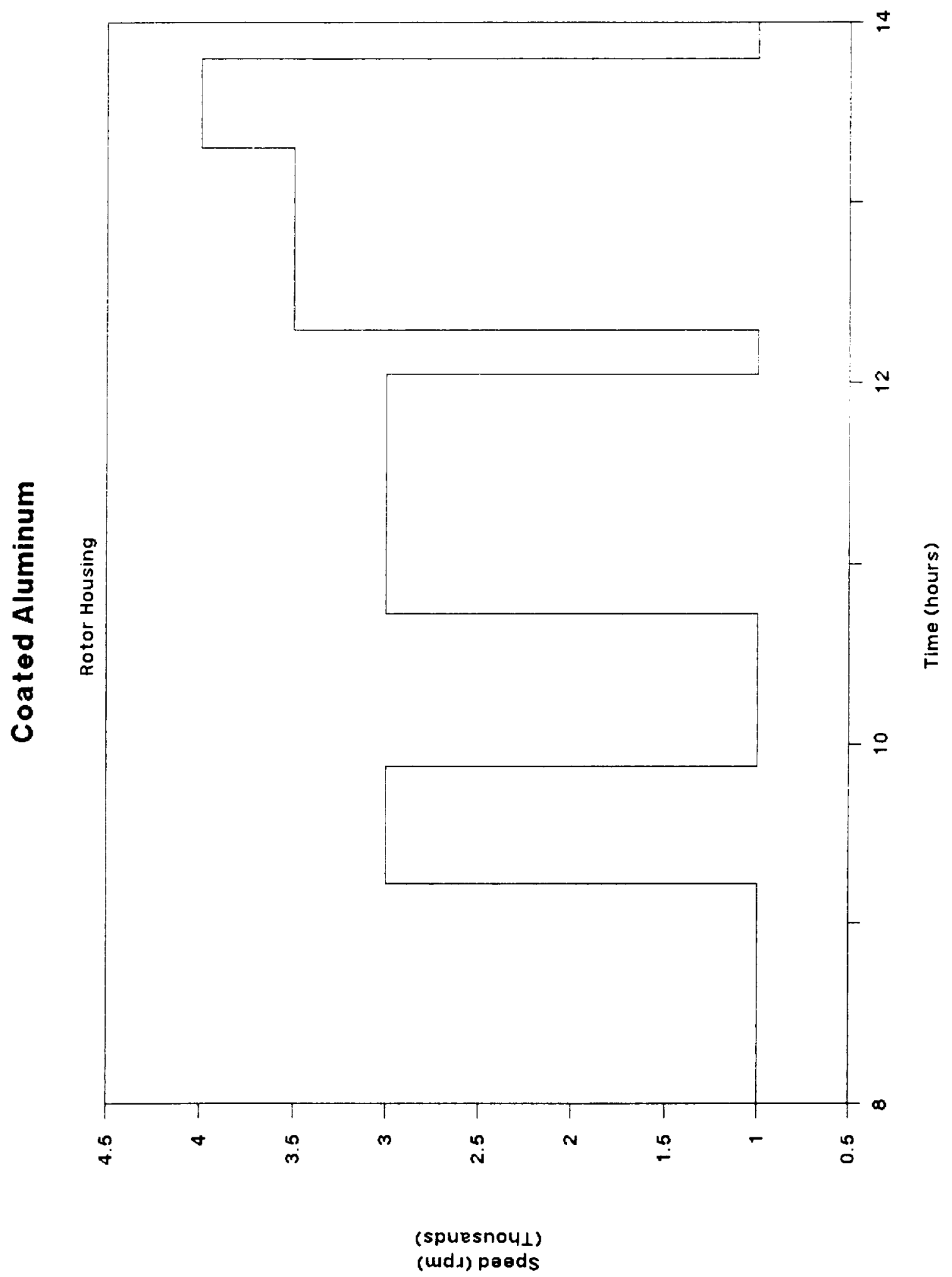

H- 5 


\begin{tabular}{|c|c|c|c|}
\hline$\overline{\mathrm{g}}=\underline{\underline{G}}$ & $\Xi \Xi \Xi \Phi$ & 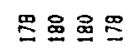 & $\Xi \Xi$ \\
\hline $\overrightarrow{8} \leq \underline{\Xi}$ & $\tilde{\Phi} \tilde{\Phi} \tilde{\Phi} \tilde{\Phi} \widetilde{\Phi} \vec{\Phi} \tilde{\Phi} \bar{\infty}$ & $\overrightarrow{\boldsymbol{\omega}} \tilde{\boldsymbol{\Phi}} \mathbf{\boldsymbol { m }} \overline{\boldsymbol{m}}$ & 대 \\
\hline 点悉 & 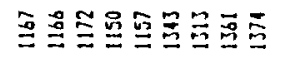 & 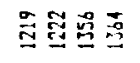 & 号吕 \\
\hline 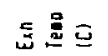 & 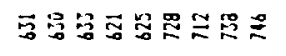 & 可要是事 & $\because:$ \\
\hline$\leq \mathbf{a}$ & 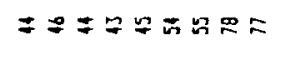 & $\stackrel{0}{=\infty}$ & $\because 8$ \\
\hline$\leq \Xi$ & 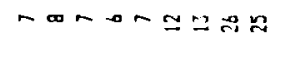 & $\infty+80$ & $\therefore ?$ \\
\hline$\stackrel{0}{\frac{0}{3}} \Xi$ & 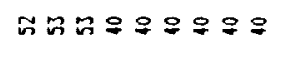 & 99?요 & $\approx z$ \\
\hline 足气 & 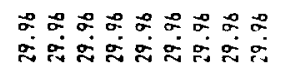 & 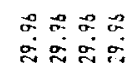 & 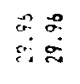 \\
\hline 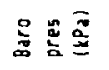 & 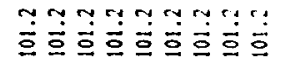 & 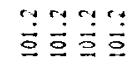 & 葛 \\
\hline 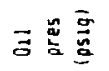 & $\approx \approx 5 \approx 55 \Xi 5$ & 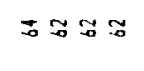 & $\ddot{6} \approx$ \\
\hline 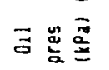 & $\Xi \Xi \Xi \Xi \Xi \Xi \Xi \Xi \Xi$ & $\Xi \Xi \Xi ミ$ & $\Xi \approx$ \\
\hline 总高高 & $\simeq \simeq \simeq 99 \sigma \circ \alpha \circ$ & $\because=2$ & $\simeq$ \\
\hline 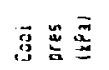 & 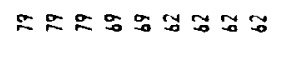 & 可示文 & 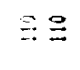 \\
\hline 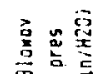 & 000000000 & 0000 & $\infty$ \\
\hline 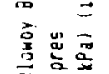 & 000000000 & 0000 & $=0$ \\
\hline 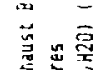 & 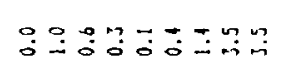 & 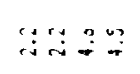 & $\because: 2$ \\
\hline$\tilde{n}$ & $80 \% 25890$ & $==0$ & \\
\hline & 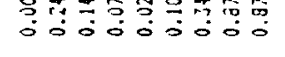 & 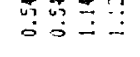 & 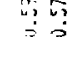 \\
\hline 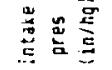 & 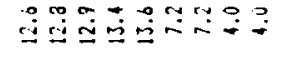 & 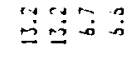 & $\stackrel{9}{i: \stackrel{m}{:}}$ \\
\hline 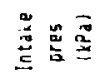 & 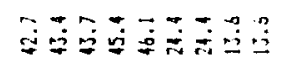 & $\risingdotseq=$ & 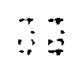 \\
\hline 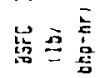 & 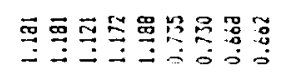 & 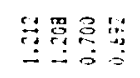 & $\stackrel{5}{3}$ \\
\hline 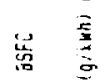 & 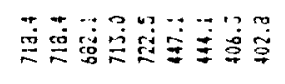 & 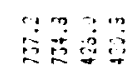 & 落 \\
\hline 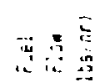 & 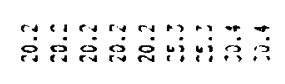 & 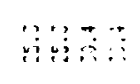 & 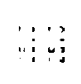 \\
\hline $\overrightarrow{9}$ & 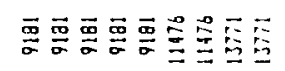 & 哭䡉星 & $\stackrel{n}{2}$ \\
\hline 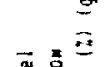 & $\infty \infty \infty \infty \infty)=9 \simeq \simeq$ & $99 \underline{9}$ & $\therefore \geq$ \\
\hline & & & \\
\hline 爰 & 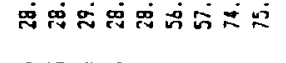 & 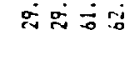 & 19 \\
\hline 岕 & 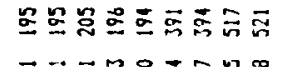 & 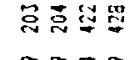 & 汸里 \\
\hline 袁 & $\vec{\Xi}=0.90$ & 争家家 & ن \\
\hline 器 & 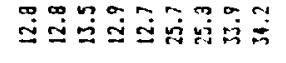 & 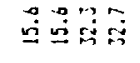 & $\because: \frac{\pi}{2}$ \\
\hline 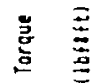 & 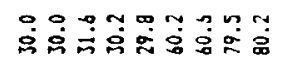 & 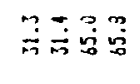 & $\therefore$ \\
\hline 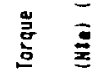 & 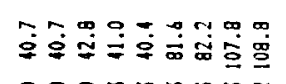 & 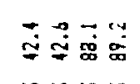 & $\underset{9}{9}$ \\
\hline$\frac{\mathbf{z}}{\mathbf{z}}$ & 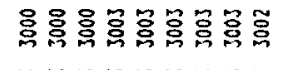 & 总总勇总 & 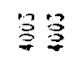 \\
\hline 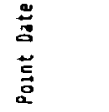 & 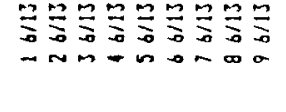 & 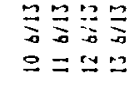 & $\frac{2}{5}$ \\
\hline
\end{tabular}

\section{ORIGINAL FAATE IS OF POOR QUALITY}




\section{ORIGIRHE FASE is
OF POOR QUALITY}

\begin{tabular}{|c|c|c|c|}
\hline 宝言可 & 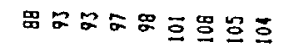 & 호오옹 & $\Xi \Xi$ \\
\hline$\underline{\underline{a}}$ & 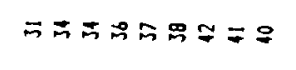 & $90 \div 2=$ & \\
\hline$=\Xi$ & 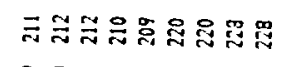 & 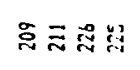 & \\
\hline$\equiv \Xi$ & 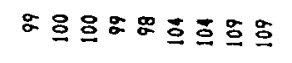 & $\mathscr{2} \approx \Phi$ & $=9$ \\
\hline 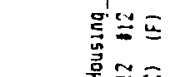 & 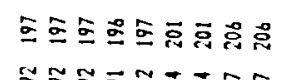 & さむき & $\Xi \nsubseteq$ \\
\hline$\because \overline{0}$ & 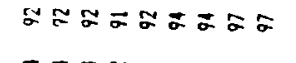 & るるよま & \\
\hline 三 三ِّ. & 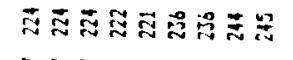 & 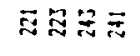 & $\hat{i}$ \\
\hline 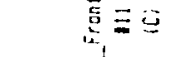 & ఏ气 & $\stackrel{s}{ \pm} \equiv=$ & $\therefore:$ \\
\hline 3 & 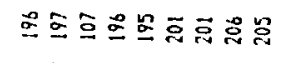 & 몽요용 & 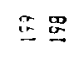 \\
\hline$\Xi \Xi$ & 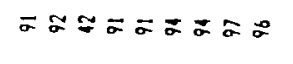 & テこのま & $=$ \\
\hline$\simeq$ & 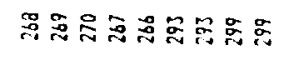 & 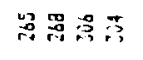 & 法触 \\
\hline$=\Xi$ & 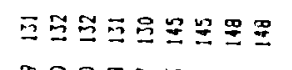 & 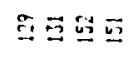 & 量骂 \\
\hline 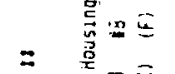 & 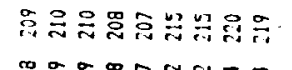 & 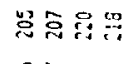 & $\because:$ \\
\hline 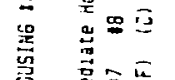 & 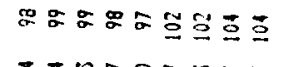 & 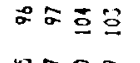 & $3:$ \\
\hline 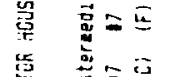 & 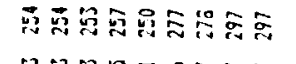 & 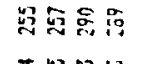 & $\therefore$ \\
\hline$=$ & 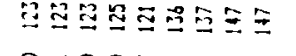 & 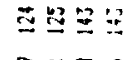 & 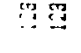 \\
\hline$\frac{5}{x}$ & 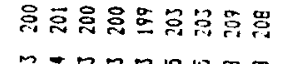 & 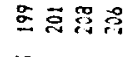 & 33 \\
\hline$=$ & 25 & 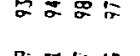 & $\because 2$ \\
\hline $\begin{array}{l}2= \\
03\end{array}$ & 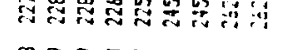 & 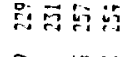 & $3:$ \\
\hline تي & 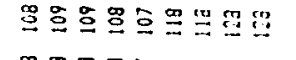 & $\stackrel{0}{=} \equiv$ & $\because$ \\
\hline$=5$ & 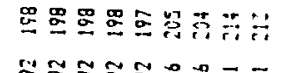 & 里是萿管 & 綽 \\
\hline $\begin{array}{l}3 \\
\underline{x} \\
\underline{5}\end{array}$ & 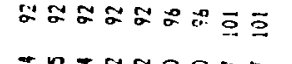 & 209 & $\vec{x}$ \\
\hline$=$ & 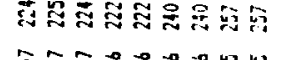 & $\approx$ & 溚 \\
\hline$\stackrel{5}{a}=$ & 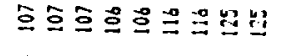 & 998 & $\because \because !$ \\
\hline$\approx \Xi$ & 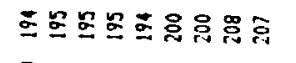 & 玉ますう & $\Xi \Xi$ \\
\hline 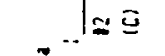 & 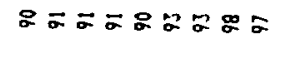 & るるこっ & $\approx \ddot{\alpha}$ \\
\hline 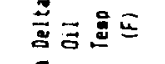 & 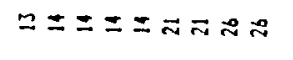 & 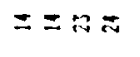 & $\approx=$ \\
\hline 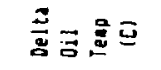 & $-\infty \infty \infty \infty \simeq= \pm$ & $\infty+2=2$ & $==$ \\
\hline$\tilde{z} \Xi$ & 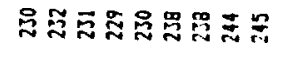 & 串監三品 & 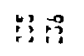 \\
\hline $\overrightarrow{\Xi \Xi \Xi \Xi ~}$ & 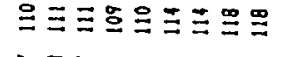 & 오로 & 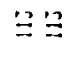 \\
\hline $\bar{a}=\bar{E}$ & 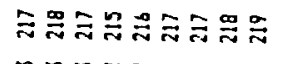 & 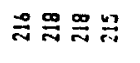 & $\therefore \equiv$ \\
\hline $\bar{\Xi} \leq \Phi$ & 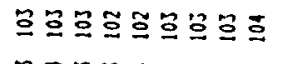 & 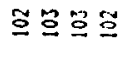 & $\dddot{g}$ \\
\hline$\overline{8} \tilde{3} \bar{z}$ & 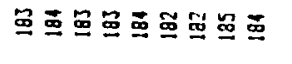 & 西五总 & 里 \\
\hline 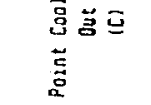 & 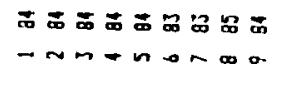 & 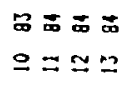 & $\begin{array}{l}\text { in } \\
=0 \\
=0\end{array}$ \\
\hline
\end{tabular}


1 
APPENDIX I

COATED CAST IRON

ROTOR HOUSING DATA

$I-1$ 
COATED CAST IRON ROTOR HOUSING DATA

TABLE OF CONTENTS

Title

Page

Coated Cast Iron Chart. . . . . . . . . . . . . . . . I-3

Coated Cast Iron Chart. . . . . . . . . . . . . . . . . I-4

Coated Cast Iron Chart. . . . . . . . . . . . . . . . . I-5

Cast Iron Rotor Housing Data. . . . . . . . . . . . . . . . I-6

Cast Iron Rotor Housing Data. . . . . . . . . . . . . . . I-7 


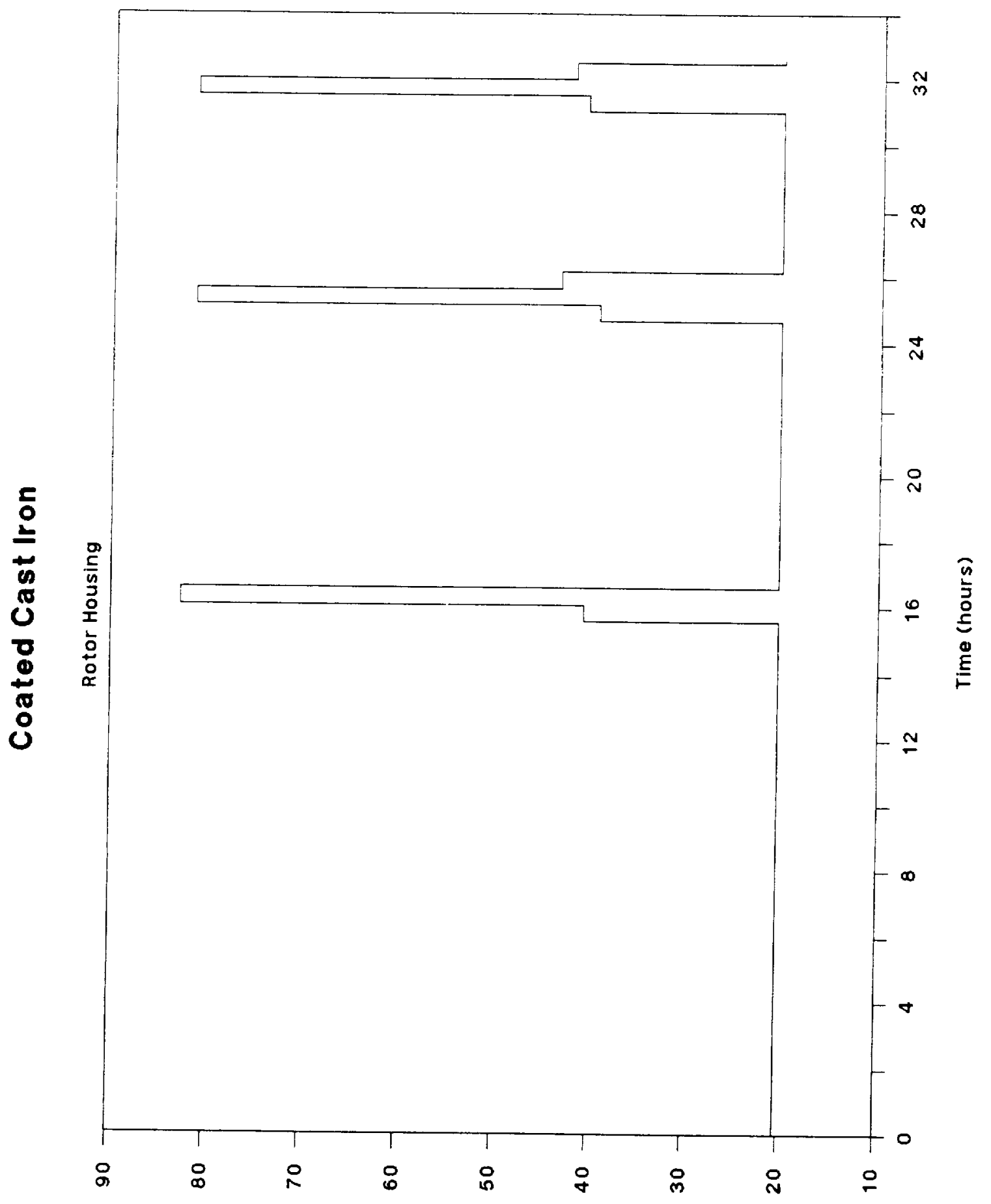

$\left(w_{* N}\right)$ enb 101

$$
\text { I - } 3
$$




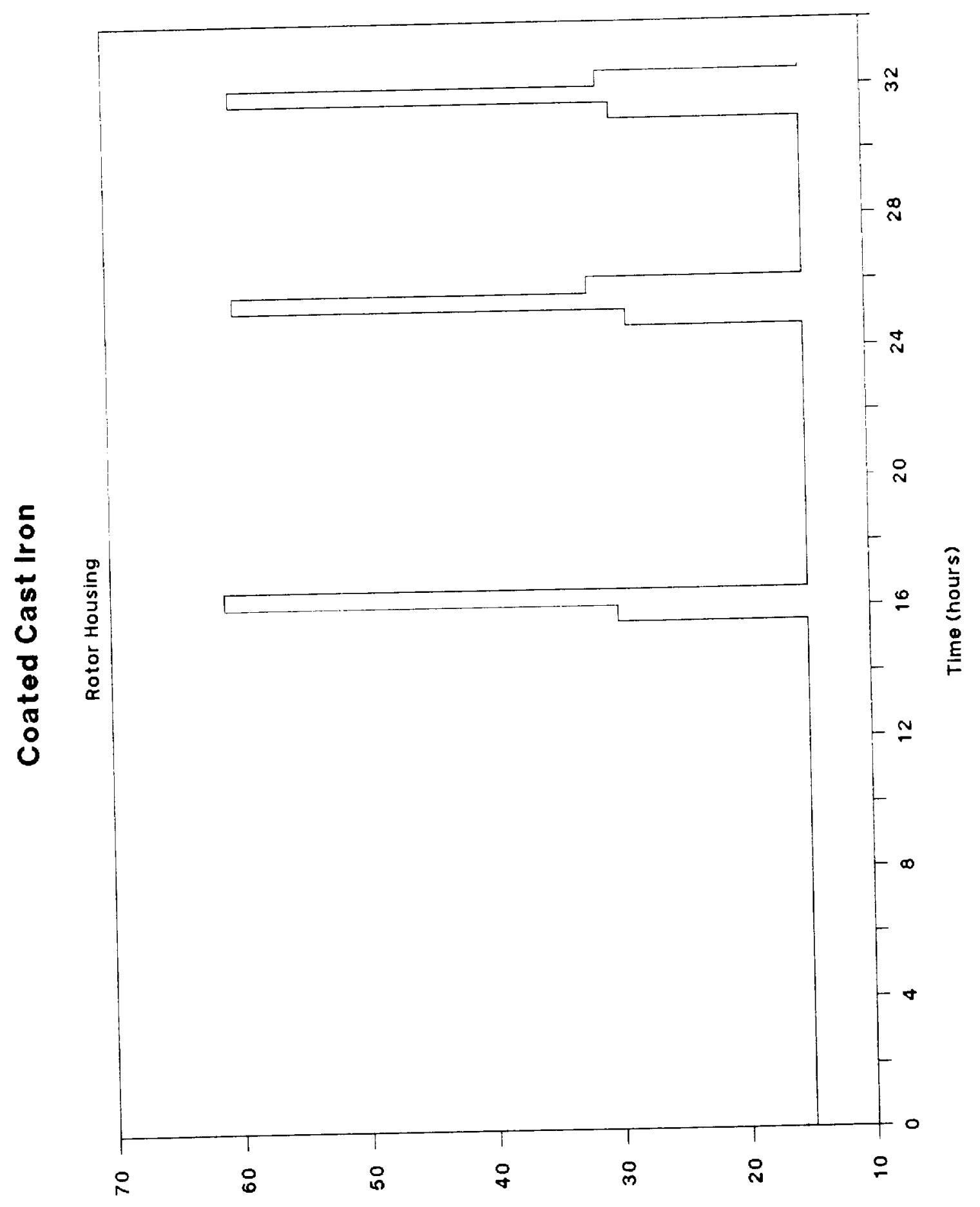

$(1+*$ sql) anbsol

I -4 


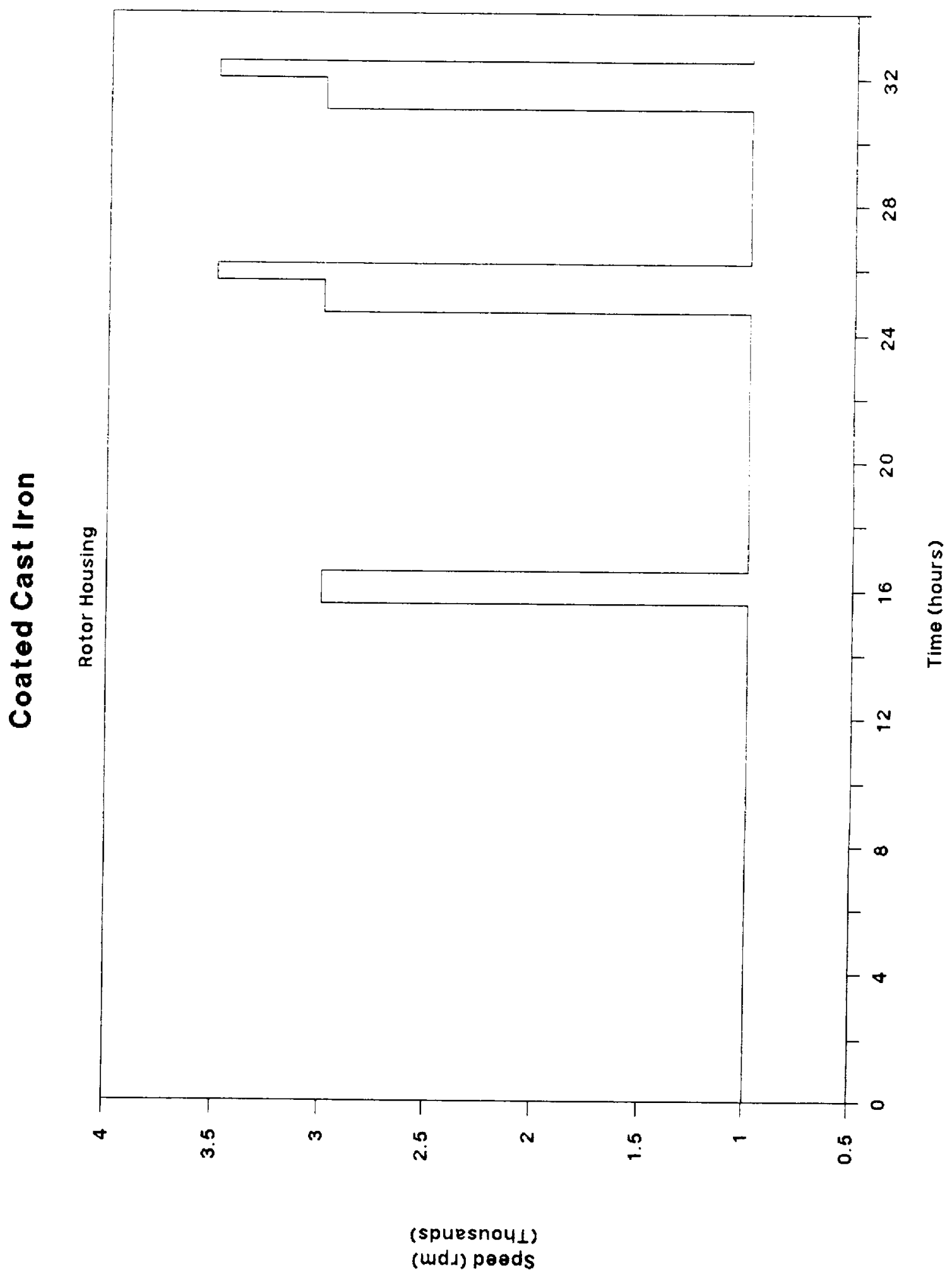

I - 5 


\begin{tabular}{|c|c|c|c|}
\hline $\overrightarrow{\mathrm{g}} \leq \bar{z}$ & 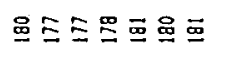 & 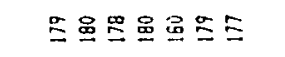 & 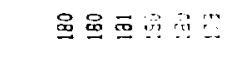 \\
\hline $\bar{g} \leq \Xi$ & 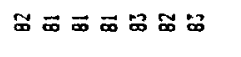 & 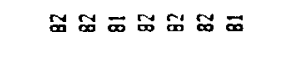 & 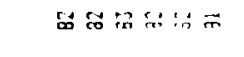 \\
\hline 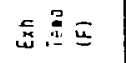 & 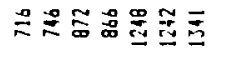 & 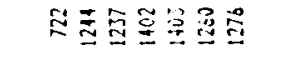 & 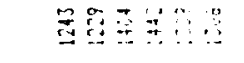 \\
\hline 5 & 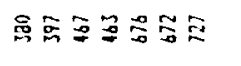 & 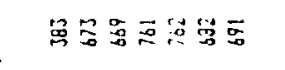 & 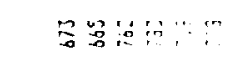 \\
\hline 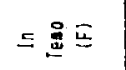 & 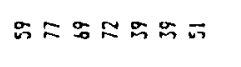 & $\bar{x}=0=8=?$ & 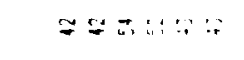 \\
\hline$\because \overline{0}$ & $\because \sin \pi+=$ & $=\infty \infty$ & מ : : : " : " \\
\hline 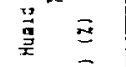 & 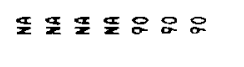 & 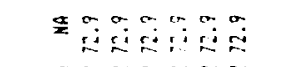 & 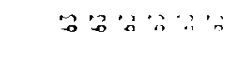 \\
\hline 号荾高 & $\frac{x}{x} \frac{x}{x} \frac{x}{x}$ & 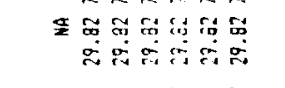 & 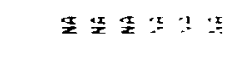 \\
\hline 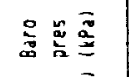 & 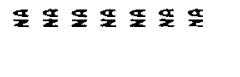 & 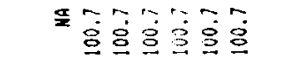 & 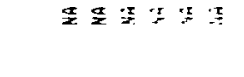 \\
\hline 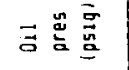 & $\because 8=5350$ & 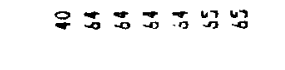 & 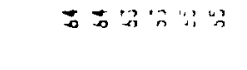 \\
\hline 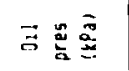 & 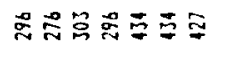 & 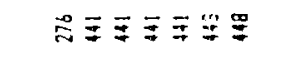 & 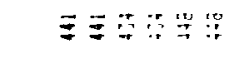 \\
\hline 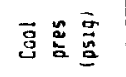 & 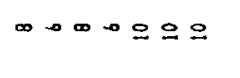 & $\sin x \cos x$ & $\sigma \infty \mathrm{or}=\cdots$ \\
\hline $\overrightarrow{3}$ & 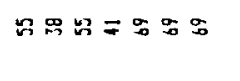 & $\vec{m}=0$ & 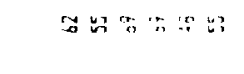 \\
\hline 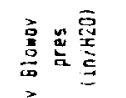 & 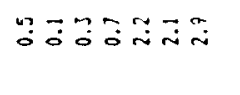 & 0000000 & $0=-$ \\
\hline 勇点 & 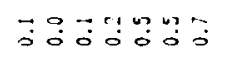 & 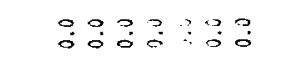 & $\because 8: \therefore$ \\
\hline 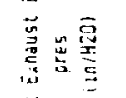 & 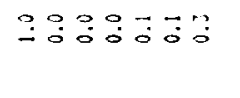 & 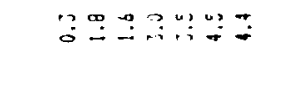 & 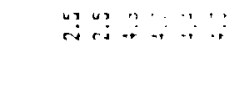 \\
\hline 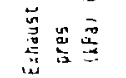 & 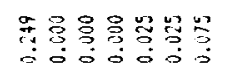 & 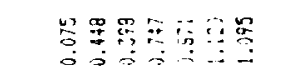 & 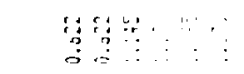 \\
\hline 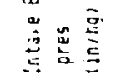 & 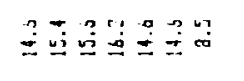 & 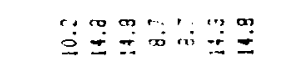 & $\vec{E}=\cdots$ \\
\hline 童 & 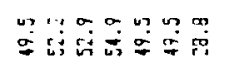 & 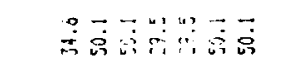 & 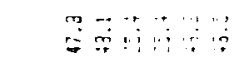 \\
\hline 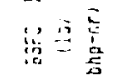 & 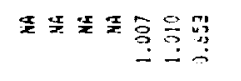 & 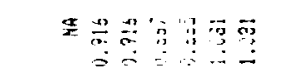 & 的: \\
\hline$\frac{\sqrt{3}}{3}$ & $x x \geq x \div$ & 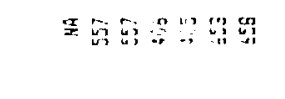 & 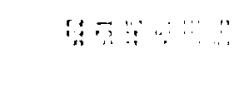 \\
\hline 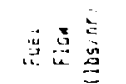 & 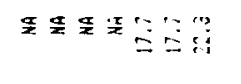 & 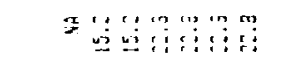 & $\because \vdots: \vdots$ \\
\hline 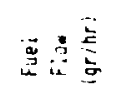 & 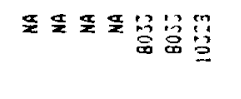 & 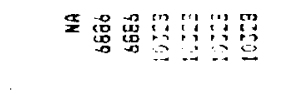 & 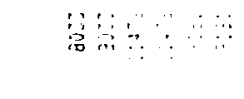 \\
\hline 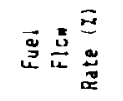 & 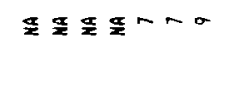 & $x=0000$ & $\cdots$ \\
\hline 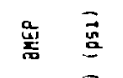 & 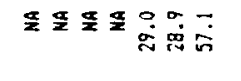 & 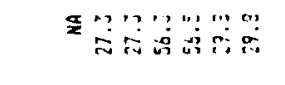 & 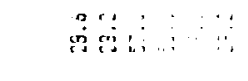 \\
\hline 訔 & 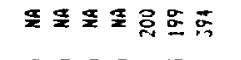 & 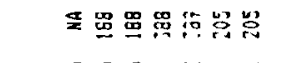 & as: \\
\hline 言 & 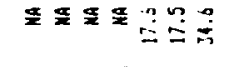 & 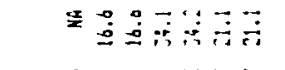 & $\begin{array}{l}? \\
=\end{array}$ \\
\hline 喜 衰 & 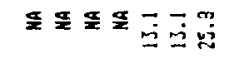 & 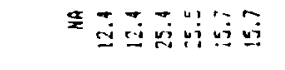 & $\begin{array}{l}2 \\
0\end{array}$ \\
\hline 蒙䒿 & 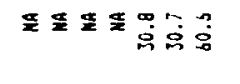 & 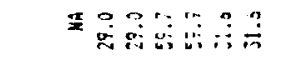 & \begin{tabular}{l}
3 \\
\hdashline
\end{tabular} \\
\hline 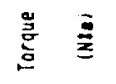 & 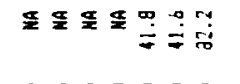 & 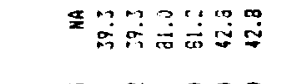 & 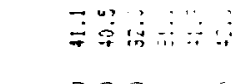 \\
\hline \pm & 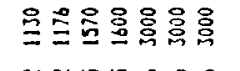 & 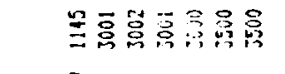 & 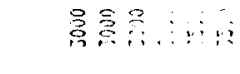 \\
\hline 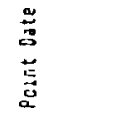 & 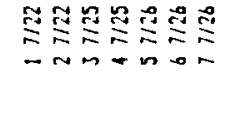 & 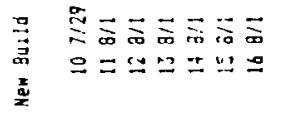 & 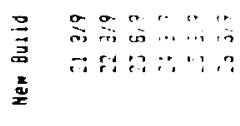 \\
\hline
\end{tabular}

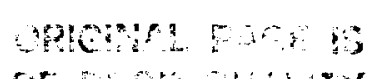
mothr phar 


\section{ORIGHAL FABE IS
OF POOR QUALTY}

\begin{tabular}{|c|c|c|c|}
\hline 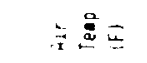 & 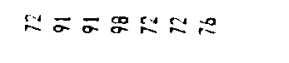 & 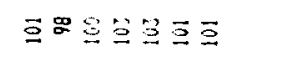 & $8 \approx$ \\
\hline$=$ & A的的AN & 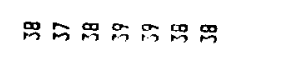 & N界星可的的 \\
\hline & 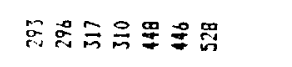 & 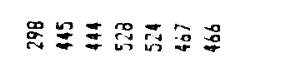 & 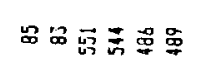 \\
\hline$=$ & 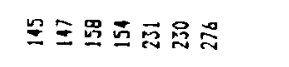 & 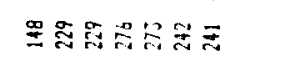 & 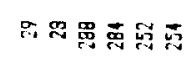 \\
\hline & 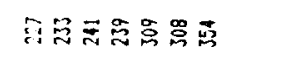 & 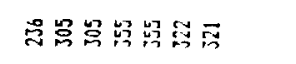 & 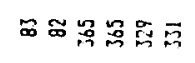 \\
\hline & $9 \cong \cong \varrho \ddot{口}$ & 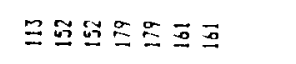 & 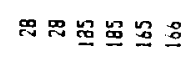 \\
\hline & 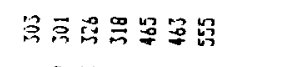 & 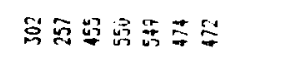 & 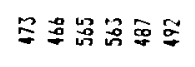 \\
\hline 5 & 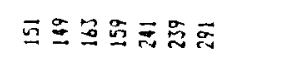 & 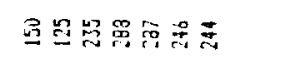 & 点识识 \\
\hline & 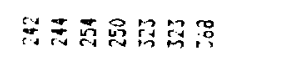 & 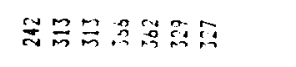 & $\overrightarrow{5}$ \\
\hline 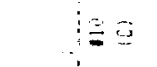 & 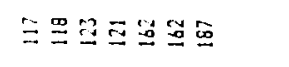 & 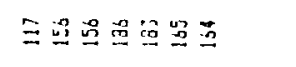 & $\Xi \cong$ \\
\hline$=$ & 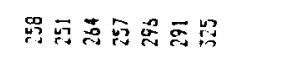 & 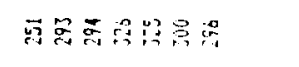 & 里 \\
\hline$=0$ & 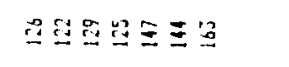 & 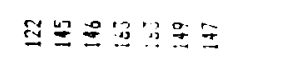 & $\underline{2}$ \\
\hline 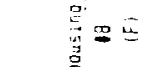 & 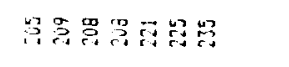 & 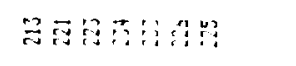 & 品 \\
\hline & 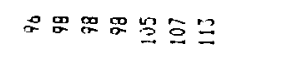 & 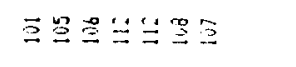 & 主要 \\
\hline$m=\bar{m}$ & 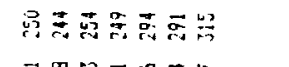 & 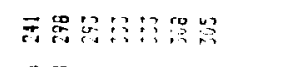 & 官吕 \\
\hline$=$ & 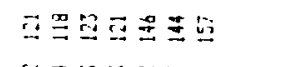 & 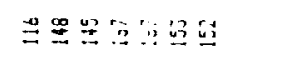 & 92 \\
\hline & 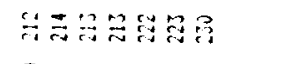 & 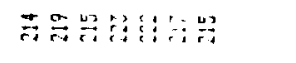 & 98 \\
\hline$\therefore$ & 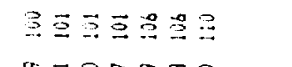 & 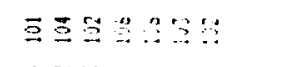 & $\underline{3}$ \\
\hline$\because$ & 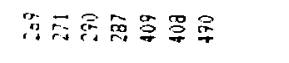 & 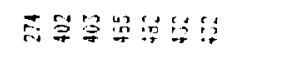 & 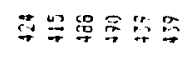 \\
\hline$=$ & 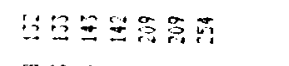 & 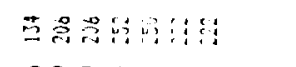 & 蕰 \\
\hline & 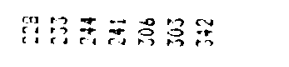 & 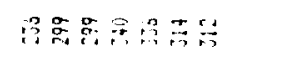 & $\frac{9}{7}=$ \\
\hline & 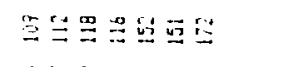 & 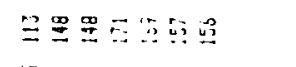 & 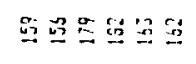 \\
\hline (2) & 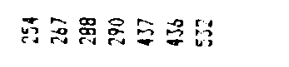 & 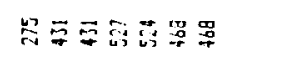 & 9 \\
\hline & $\cong \ddot{エ}$ & 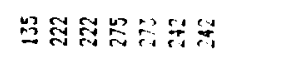 & 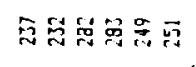 \\
\hline$t_{0}$ & 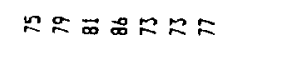 & 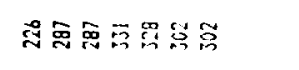 & $\sigma 0$ \\
\hline $1=$ & 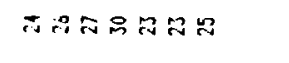 & 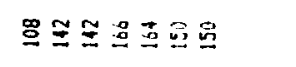 & 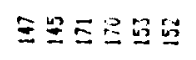 \\
\hline 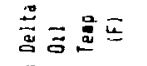 & 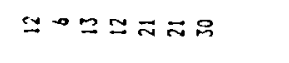 & 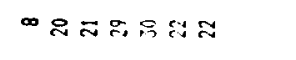 & 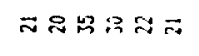 \\
\hline & $\rightarrow m-n \simeq=$ & $-=\simeq ュ ニ \simeq \simeq$ & $\simeq=a=\check{\simeq}$ \\
\hline & 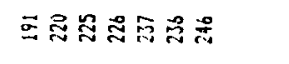 & 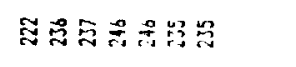 & 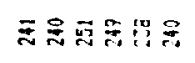 \\
\hline$\vec{a}$ & 思吉思䍐三骂 & 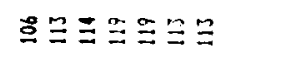 & $\stackrel{2}{=} \Xi$ \\
\hline$\vec{B} s$ & 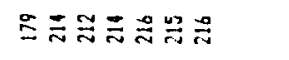 & 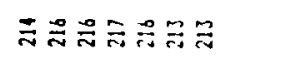 & 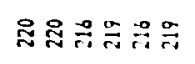 \\
\hline $\overrightarrow{\ddot{B}} \leq$ & 心 & 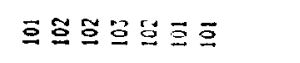 & 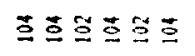 \\
\hline$\vec{B}$ & 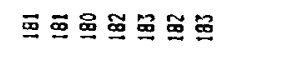 & 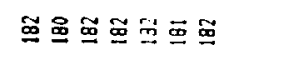 & 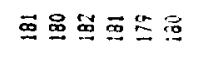 \\
\hline 总 & 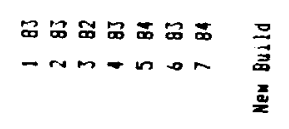 & 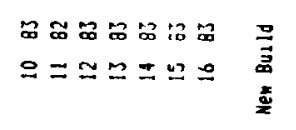 & 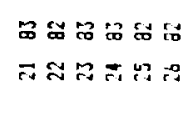 \\
\hline
\end{tabular}


